
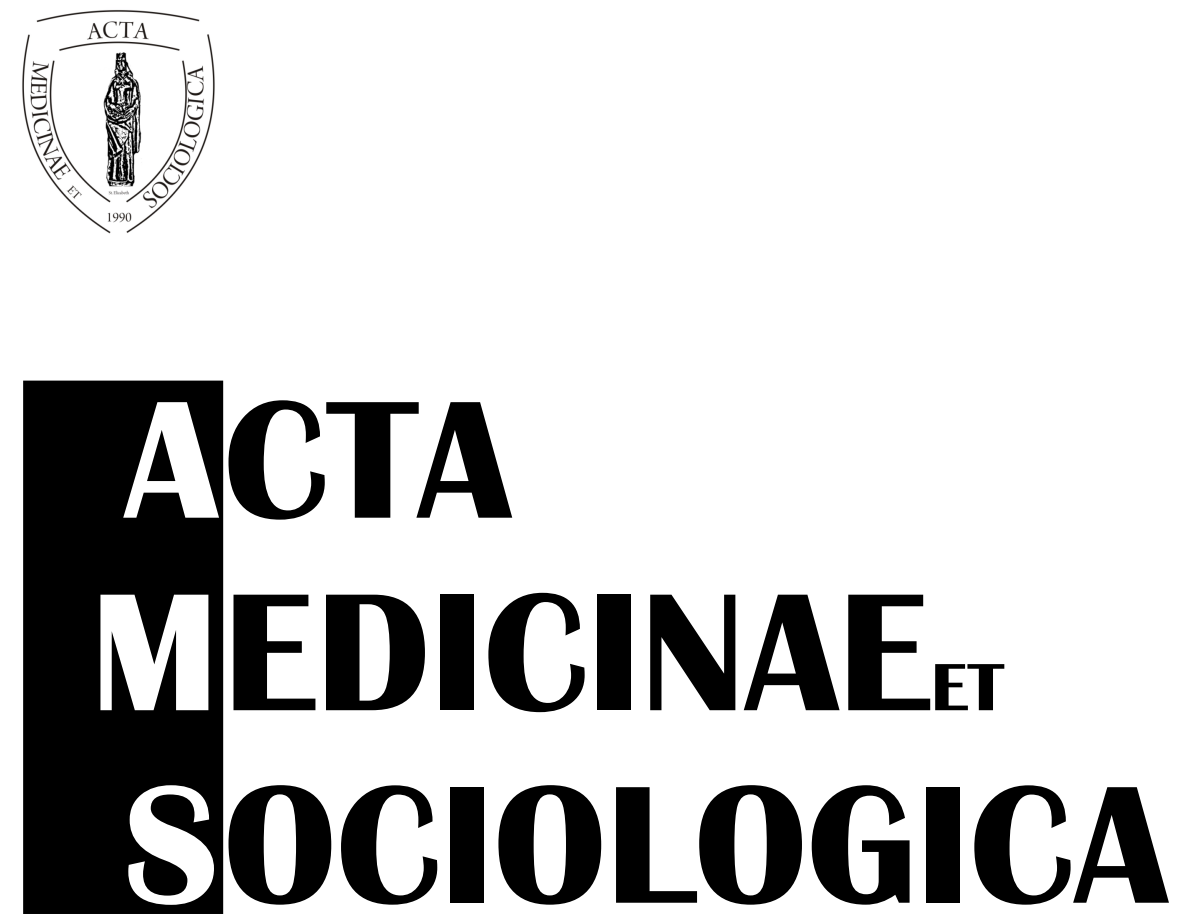

Vol.5. No.14-15. 2014 


\section{Acta}

\section{Medicinae}

et

\section{Sociologica}

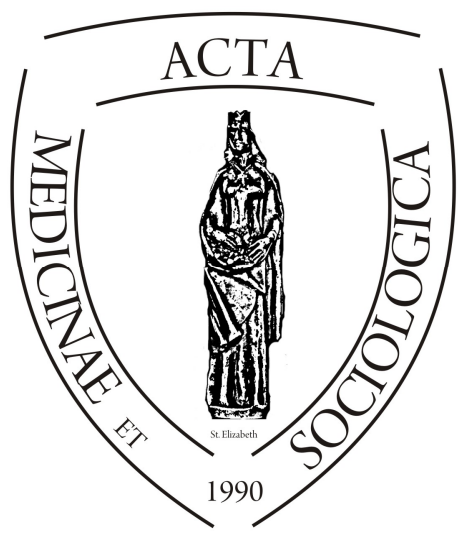

\section{Vol.5. No.14-15. 2014.}

Debreceni Egyetem

Egészségügyi Kar, Nyíregyháza 
Acta Medicinae et Sociologica

5. évfolyam 14-15. szám 2014

Volume 5. No. 14-15. 2014

Alapítás éve: 2010

Főszerkesztő: Dr. Kiss János

Főszerkesztő-helyettes: Dr. Fónai Mihály

Szerkesztők: Dr. Hüse Lajos és Dr. Takács Péter

Olvasószerkesztő: Balogh Erzsébet

Szerkesztőbizottság: Dr. Semsei Imre (elnök), Dr. Kiss János (társelnök),

Mikóné Márton Júlia (titkár), Dr. Fábián Gergely,

Dr. Kósa Zsigmond, Dr. Ködmön József, Dr. Kalapos István,

Dr. Lőrincz István, Rákóczi Ildikó, Csorba Ákos, Dr. Lukácskó Zsolt,

Dr. Szöllősi János, Dr. Takács Péter

Tudományos tanácsadók:

Prof. Dr. Muszbek László, akadémikus

Prof.Dr. Pethő Attila, akadémikus

Felelős kiadó:

Debreceni Egyetem Egészségügyi Kar

Szerkesztőség:

4400 Nyíregyháza, Sóstói út 2-4.

Tel.: (42) 404-411, Fax: (42) 408-656

e-mail: acta.m.s@foh.unideb.hu

Nyomdai előkészítés: Ricsei Béla

HU - ISSN 2062-0284 


\section{Tartalomjegyzék}

Fábián Gergely, Thomas R. Lawson, Fónai Mihály, Kiss János, Eric R. Soelter

An International Comparison of the Career of Social WorkBy Students in Social Work

Oroszné Pál Zsuzsanna, Sárváry Andrea

Segítői hivatásra készülő hallgatók coping stratégiáinak megnyilvánulási lehetőségei nehéz, szakmai helyzetek kezelése során

Suta Erika, Sárváry Andrea

A mellrák pszichoszociális vonatkozásainak vizsgálata

\section{Bojti István}

Rendszerszemléletủ és narratív megközelítések alkalmazása a terápiában

Szabados György

Civil szervezetek, civil engagement, civil érintettség

Sipos Gábor, Szücs Edit, Takács Tímea, Matkó Andrea

A vezetési stílus, a változási készség és a konfliktus kezelés vizsgálata egy magyarországi Multinacionális vállalatnál

Makszim Györgyné

A vállalati elit és a kapcsolati tőke viszonyának elemzése

\section{Zolnai Erika}

Az angol továbbképzési és szakképzési rendszer kihívásai a XXI. század elején

\section{Szatlóczkyné Gajdóczki Zsuzsanna}

Gondolatok és reflexiók a „Helyi szociális ellátórendszer Magyarországon” címü kötetről 


\section{Content}

Gergely Fábián, Thomas R. Lawson, Fónai Mihály, János Kiss, Eric R. Soelter

An International Comparison of the Career of Social Work by Students in

Social Work

Zsuzsanna Oroszné Pál, Andrea Sárváry

Exhibition Possibilities of Coping Strategies in Difficult Professional

Situations among Students Preparing for Helping Professions

Erika Suta, Andrea Sárváry

Examining Psychosocial Aspects of Breast Cancer

\section{István Bojti}

Using Systematic and Narrative Approaches in Therapy

\section{György Szabados}

Civil Organizations, Civil Engagement and Civil Involvement

Gábor Sipos, Edit Szücs, Tímea Takács, Andrea Matkó

Examining Leading Style, Readiness for Change and Conflict Management at a Multinational Company in Hungary

Makszim Györgyné

Analysis of the Relation between Management and Relation Capital

\section{Erika Zolnai}

Challenges in the British Further Training and Vocational Education in the Early 21 st Century

\section{Szatlóczkyné Gajdóczki Zsuzsanna}

Thoughts and Reflections on Local Social Care System in Hungary written by Ferenc Bódi 


\section{UNIVERSITY \\ OF DEBRECEN \\ FACULTY OF \\ HEALTH}

NYÍREGYHÁZA

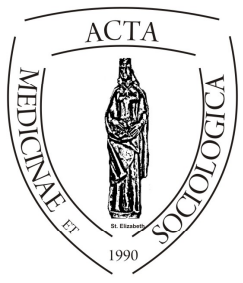

ACTA

MEDSOC

VOLUME 5 .

2014

\title{
An International Comparison of the Career of Social Work by Students in Social Work
}

\author{
Gergely Fábián*, Thomas R. Lawson**, Mihály Fónai***, \\ János Kiss*, Eric R. Soelter** \\ *Faculty of Health-University of Debrecen, **Kent School of Social Work- \\ University of Louisville, ***Faculty of Law-University of Debrecen
}

\begin{abstract}
Globalization and international interactions have launched investigations into cross national comparisons. The current research posed two fundamental questions (1) "Are their similar professional patterns and values in social work that are universal across national and cultural differences?" and (2) "Are their national or cultural dimensions that influence or shape differences even when there is a underlying professional similarity across cultures and nationalities?"

A sample of 356 social work students from Hungary, Germany, Finland, Italy and the United states was given a 2 part survey. The first part contained demographics and questions about social work for example, what influenced their choice, what are the values and characteristics of the profession and what professions are similar to social work. While some differences emerged there was much more similarity in values and perceptions than differences. The second part was a 36 item scale with four sub-scales specifically developed and validated to determine their perception of what is important in a social work job. The job scale successfully discriminated between different countries and additionally was able to show which countries were more similar, for example the Germans were most like Americans and Hungarians were more like the Finnish.
\end{abstract}


Keywords: social work students, cross national comparison, professional patterns and values, national and cultural dimensions, recruiting, job scale.

\section{Introduction}

Over the past few years, given the significant changes in the international interactions and the effects of globalization, there have been investigations into the similarities and differences between countries concerning transfer of programs and knowledge and also education and professional training and identification. Extending the work of Mihály Fónai, Gergely Fábián and János Kiss in 1998 that compared German, Finish, Italian and Hungarian social work students, the present study refines the previous comparisons and presents additional comparisons to social work students from the United States. These comparisons raise the very interesting question of whether in different countries the same profession (social work) is shaped by the similarities within the profession to a more similar pattern and also if the differences between cultures in these countries can indeed create differential patterns even within a similar professional pattern. Thus, there are two fundamental questions to be addressed by this research: (1) Are there similar professional patterns and values in social work that are universal across national and cultural differences and (2) are there national or cultural dimensions that influence or shape differences even when there is an underlying professional similarity across the cultures and nationalities? One may view the countries included in the present study as representing diverse cultural and national as well as historical backgrounds irrespective but also including the profession of social work.

In addition to the overarching two questions stated above, there were many other questions that are addressed within the context of the present research. Are individuals who select the profession of social work drawn to the profession by a concern for others? Will the demographics of the profession (age, gender, education, family background) of the profession be consistent across nationalities and cultures? Will attitudes and perceptions of social work be consistent across cultures? If there is a consistent perception of social work across cultures will there be any relative differences in the amount of that particular belief? For example all students irrespective of country will view social work as having lower status compared to other professions but that a given country may differ significantly from another country in the amount of agreement with the statement. Can scales be developed that address the attributes of a social work professional job that would be applicable to all 
students of social work regardless of country and but also discriminate between students from different countries?

\section{The sample}

Of the total sample of 356 social work students there were $113(31 \%)$ Hungarian students, 63 (18\%) German students, 65 (18\%) Finish students, 56 (16\%) Italian students, and 59 (17\%) American students. The Hungarian, German, Finish and Italian students were all in the last year of undergraduate social work education while the American students were in the first year of a Master of social work program. The American students however were selected as students without any prior social work education and therefore were not in advanced placement in a social work program and did not have an undergraduate degree is social work (BSW) at the time of the study to that they would be more similar to the European students. All students were administered a questionnaire consisting of 140 questions. The questions represent three major domains; (1) demographics (2) questions related to their attitudes about the profession of social work and social work education and (3) a 45 item scale intended to determine their feelings about a social work job.

\begin{tabular}{|c|c|c|c|c|}
\hline Hungarian & German & Finish & American & Italian \\
\hline $113(31 \%)$ & $63(18 \%)$ & $65(18 \%)$ & $59(17 \%)$ & $56(16 \%)$ \\
\hline
\end{tabular}

Table 1: Sample of students.

\begin{tabular}{|c|c|c|c|c|c|}
\hline COUNTRY & Age 18-20 & Age 21-23 & Age 24-26 & Age 27-29 & Over 30 \\
\hline Hungary & 21 & 60 & 11 & 2 & 6 \\
\hline Germany & 10 & 14 & 25 & 19 & 32 \\
\hline Italy & 20 & 53 & 18 & 7 & 2 \\
\hline Finland & 15 & 34 & 36 & 6 & 9 \\
\hline USA & 0 & 15 & 29 & 15 & 42 \\
\hline
\end{tabular}

Table 2: Age of students by country.

The table above depicts the ages of the students. The average of the groups is as follows: Hungary 22.7, Germany 27.5, Italy, 23.7, Finland 24.1 and the USA 32.8. There is a significant difference between all the groups (Chi-Square = 
127.50, $\mathrm{df}=16, \mathrm{p}=.000)$. The American students appear much older that all the other groups however a few outliers distort the American average. A better indicator of the age of the American group is the median (27) which is the same as the average of Germany. However, it is evident from the data that the United States has an older population of students in the sample which is to be expected given that they are first year graduate students. Germany also has older students than Hungarian and Italian students which are considerably younger both having about $80 \%$ of their students between the ages of 18 and 23 .

Historically social work has been a profession heavily populated by females and this finding is still supported in the present sample of students from the five participating countries all of which have an overwhelming majority of female students.

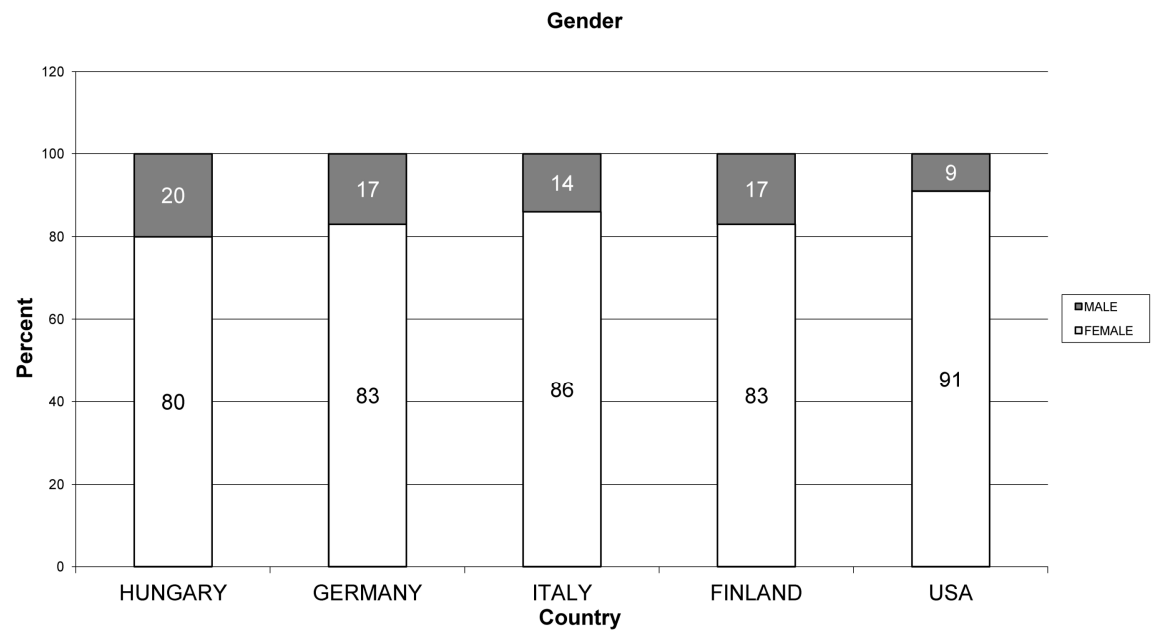

Chart 1: Gender of the students by country.

The United States had the lowest percentage of men (9\%) followed by Italy (14\%), Germany and Finland both with $18 \%$, then Hungary with the highest percentage $(20 \%)$. The overall percent of females in the 5 country sample was $83 \%$ with no significant differences between the countries (Chi Square $=4.01$, df $=4, \mathrm{p}=.39$ ) indicating that social work clearly had significantly more females than males a finding consistent with all previous studies whether within or across countries.

It was important to investigate the education level of the parents of social work students to determine if there were any differences between countries in the level of parental education. To assess if there was a difference, parental education was simply divided into whether the parent had a college education or 
not. Given the major differences in the educational systems between countries and the difficulty in developing equal definitions of level of education the only possible differentiation that could be developed was whether their parent had completed a college education. As shown below, the German student fathers had completed significantly (Chi Square $=11.92, \mathrm{df}=4, \mathrm{p}=.02)$ more education $(32 \%)$ than the students from other countries, Hungary $18 \%$, Italy $11 \%$, Finland $12 \%$ and the USA $18 \%$.

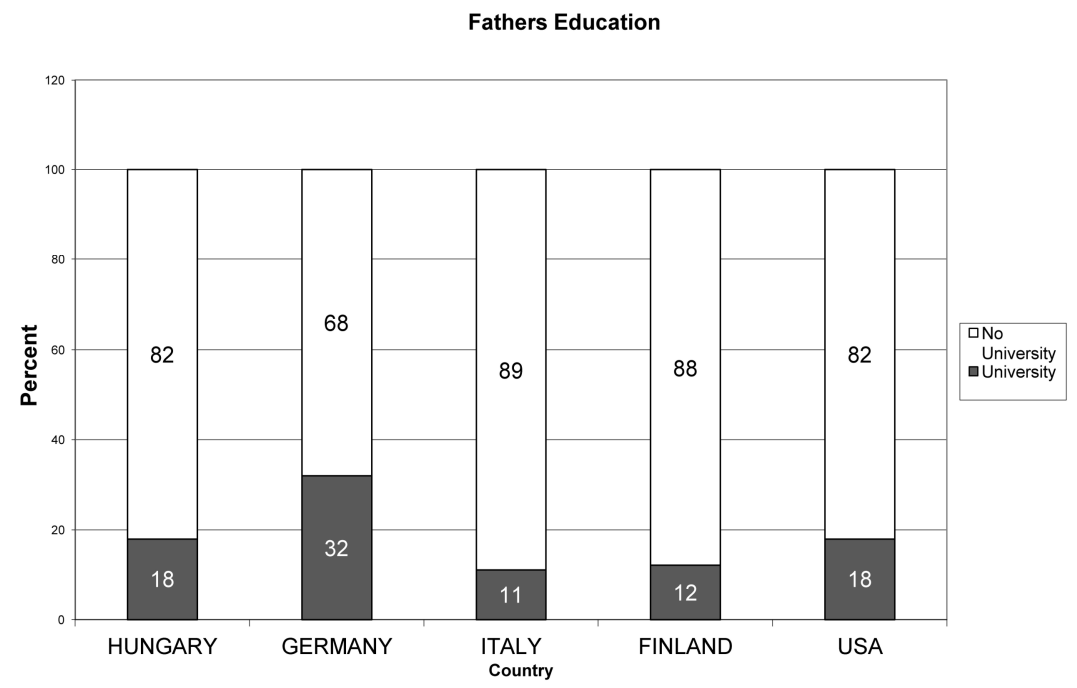

Chart 2: Fathers education.

The educational level of the mothers of the students was not significantly different between countries (Chi-Square $=3.00, \mathrm{df}=4, \mathrm{p}=.59$ ). While Italy still had the lowest percent of mothers with a college education $(9 \%)$, the other countries were very similar with the USA having the highest percent $(20 \%)$ and Germany with $19 \%$, Finland $16 \%$ and Hungary $16 \%$. What is interesting is that across countries there was very little difference between the educational level of the mothers and fathers with the exception of Germany where $32 \%$ of the fathers had a college education and only $19 \%$ of the mothers had a college education. 


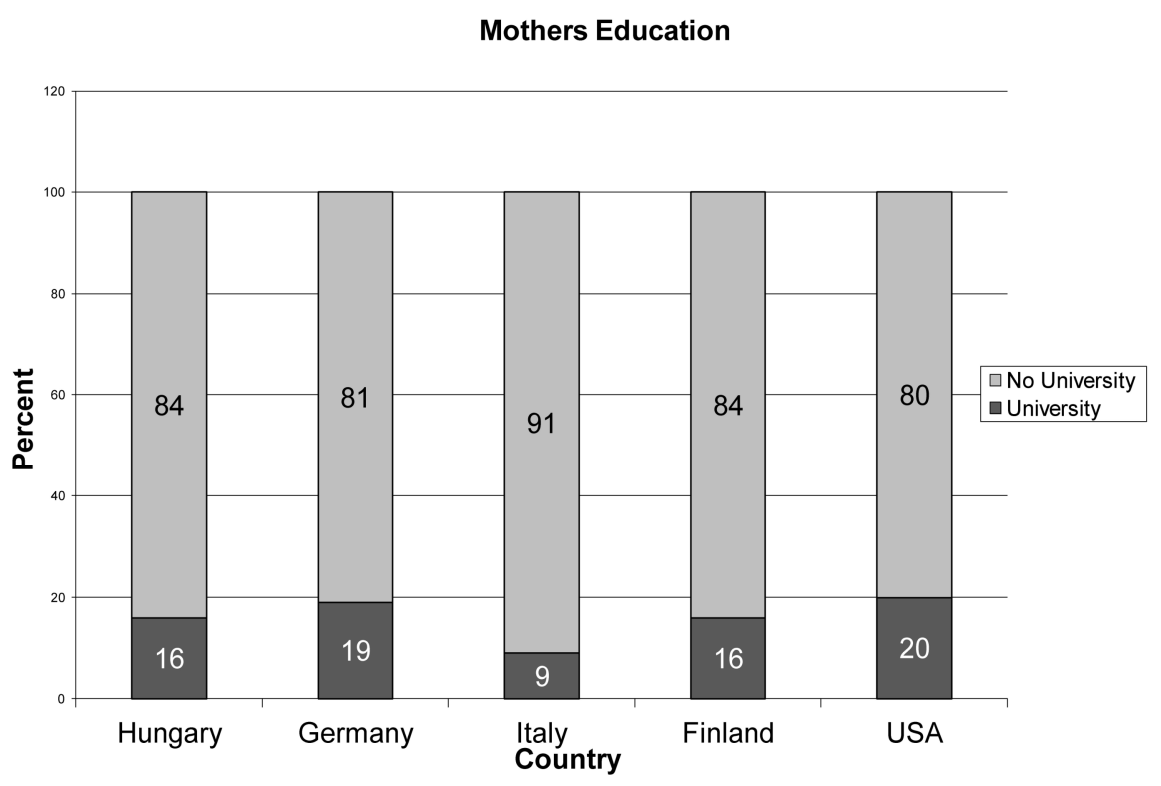

Chart 3: Mothers education.

One of the most important aspects of a person choosing a professional career is who or what influenced your choice of that particular career. The students were queried about this and the results are shown in the next table. The greatest reason for choosing social work as a profession is the student's interest in social problems with 87 percent of all students stating this as a reason. The second most important reason was that the student had already worked as a social worker. Given that none of these students had been trained professionally, the students who said that they worked as a social worker must have worked in a job that did not require advanced professional training. Possibly they worked in one that was aligned with social work and thus perceived by the student as a social work position such as child work in a community center or in a nursery or maybe as a nanny or working as an aide in an elder home. This answer was most frequently given by students from Finland and Germany, but also was frequent in the USA. It can be noted that in the USA a person with an undergraduate degree in a field related to social work may work in a position for the state that is called social work without professional training. 


\begin{tabular}{|l|c|c|c|c|c|c|c|}
\hline & Hungary & Germany & Italy & Finland & USA & $\begin{array}{c}\text { Overall } \\
\text { Percent }\end{array}$ & $\begin{array}{c}\text { Significance } \\
\text { Between } \\
\text { Countries }\end{array}$ \\
\hline Teacher & $10 \%$ & $8 \%$ & $12 \%$ & $2 \%$ & $29 \%$ & $12 \%$ & $\mathrm{P}=.00$ \\
\hline $\begin{array}{l}\text { Person with } \\
\text { Sense of } \\
\text { Vocation }\end{array}$ & $34 \%$ & $38 \%$ & $38 \%$ & $27 \%$ & $40 \%$ & $35 \%$ & $\begin{array}{l}\mathrm{P}=.171 \\
\text { Not Sig. }\end{array}$ \\
\hline $\begin{array}{l}\text { Parent } \\
\text { Example }\end{array}$ & $14 \%$ & 6 & $18 \%$ & $20 \%$ & $28 \%$ & $17 \%$ & $\mathrm{P}=.02$ \\
\hline Parent Advice & $12 \%$ & $6 \%$ & $9 \%$ & $15 \%$ & $0 \%$ & $8 \%$ & $\mathrm{P}=.05$ \\
\hline $\begin{array}{l}\text { Friend } \\
\text { Suggestion }\end{array}$ & $27 \%$ & $18 \%$ & $14 \%$ & $31 \%$ & $12 \%$ & $20 \%$ & $\mathrm{P}=.00$ \\
\hline $\begin{array}{l}\text { My Interest } \\
\text { In Social } \\
\text { Problems }\end{array}$ & $90 \%$ & $91 \%$ & $95 \%$ & $88 \%$ & $72 \%$ & $\mathbf{8 7 \%}$ & $\mathrm{P}=.01$ \\
\hline $\begin{array}{l}\text { University } \\
\text { Information }\end{array}$ & $39 \%$ & $16 \%$ & $34 \%$ & $22 \%$ & $10 \%$ & $24 \%$ & $\mathrm{P}=.00$ \\
\hline $\begin{array}{l}\text { University } \\
\text { Reputation }\end{array}$ & $16 \%$ & $10 \%$ & $11 \%$ & $14 \%$ & $22 \%$ & $15 \%$ & $\begin{array}{l}\mathrm{P}=.192 \\
\text { Not Sig }\end{array}$ \\
\hline $\begin{array}{l}\text { Already } \\
\text { Worked as } \\
\text { Social Worker }\end{array}$ & $22 \%$ & $52 \%$ & $34 \%$ & $62 \%$ & $43 \%$ & $43 \%$ & $\mathrm{P}=.00$ \\
\hline $\begin{array}{l}\text { No Other } \\
\text { Choice }\end{array}$ & $12 \%$ & $6 \%$ & $9 \%$ & $11 \%$ & $2 \%$ & $8 \%$ & $\begin{array}{l}\mathrm{P}=.07 \\
\text { Not Sig }\end{array}$ \\
\hline $\begin{array}{l}\text { Easy to be } \\
\text { Admitted }\end{array}$ & $27 \%$ & $10 \%$ & $2 \%$ & $19 \%$ & $2 \%$ & $12 \%$ & $\mathrm{P}=.000$ \\
\hline
\end{tabular}

Table 3: What influenced you to enter the social work profession?

Chi Square Test Utilized for Each Analysis.

The sample was asked to identify the various sources from which they learned about social work and their answers were not mutually exclusive. While there was not a truly single source of information, materials from the university was rated the highest and media was rated the lowest. Italy was the highest in having no information (45\%) and Finland the lowest $(3 \%)$. As a source, teachers were rated the highest by the USA (43\%) and lowest by Italy $(2 \%)$ while Germany rated university material the highest (42\%) and the USA the lowest $(14 \%)$. Finding out about social work from friends was rated high by Germany $(36 \%)$ and low by Italy and the USA (13\%), while information from a social worker was high for the USA (29\%) but low for Hungary (9\%). Being a social worker 
was where the Finish students learned about social work (51\%) but low for Italy (7\%), and studying social work before was again high for Finland (35\%) and rated low by Germany (4\%). Finally the media was placed highest by Germany $(24 \%)$ and lowest by the USA (2\%).

\begin{tabular}{|l|c|c|c|c|c|c|c|}
\hline & Hungary & Germany & Italy & Finland & USA & $\begin{array}{c}\text { Overall } \\
\text { Percent }\end{array}$ & $\begin{array}{c}\text { Significance } \\
\text { Between } \\
\text { Countries }\end{array}$ \\
\hline No Information & $26 \%$ & $31 \%$ & $\mathbf{4 5 \%}$ & $\mathbf{3 \%}$ & $21 \%$ & $25 \%$ & $\mathrm{P}=.000$ \\
\hline Teachers & $12 \%$ & $15 \%$ & $\mathbf{2 \%}$ & $19 \%$ & $\mathbf{4 3 \%}$ & $18 \%$ & $\mathrm{P}=.000$ \\
\hline $\begin{array}{l}\text { University } \\
\text { Materials }\end{array}$ & $24 \%$ & $\mathbf{4 2 \%}$ & $27 \%$ & $34 \%$ & $\mathbf{1 4 \%}$ & $\mathbf{2 8 \%}$ & $\mathrm{P}=.01$ \\
\hline $\begin{array}{l}\text { Friends at } \\
\text { University }\end{array}$ & $33 \%$ & $\mathbf{3 6 \%}$ & $\mathbf{1 3 \%}$ & $32 \%$ & $\mathbf{1 3 \%}$ & $25 \%$ & $\mathrm{P}=.02$ \\
\hline $\begin{array}{l}\text { Social } \\
\text { Worker }\end{array}$ & $\mathbf{9 \%}$ & $22 \%$ & $23 \%$ & $14 \%$ & $\mathbf{2 9 \%}$ & $19 \%$ & $\mathrm{P}=.000$ \\
\hline $\begin{array}{l}\text { Was } \\
\text { Social Worker } \\
\text { Before }\end{array}$ & $8 \%$ & $44 \%$ & $\mathbf{7 \%}$ & $\mathbf{5 1 \%}$ & $16 \%$ & $25 \%$ & $\mathrm{P}=.000$ \\
\hline $\begin{array}{l}\text { Studied } \\
\text { Social Work } \\
\text { Before }\end{array}$ & $19 \%$ & $\mathbf{4 \%}$ & $13 \%$ & $\mathbf{3 5 \%}$ & $28 \%$ & $20 \%$ & $\mathrm{P}=.000$ \\
\hline \begin{tabular}{l} 
Media \\
\hline
\end{tabular} & $12 \%$ & $\mathbf{2 4 \%}$ & $2 \%$ & $22 \%$ & $\mathbf{2 \%}$ & $12 \%$ & $\mathrm{P}=.000$ \\
\hline
\end{tabular}

TTable 4: How did you learn about social work?

Chi Square Utilized for Each Test.

An important aspect to investigate is why a social work student wants to become a social worker. This was addressed by asking a series of 5 questions that were ranked from 1 to 5 with a one being low importance and 5 being high importance. All questions were mutually exclusive and represent independent judgments. 


\begin{tabular}{|l|c|c|c|c|c|c|c|}
\hline & Hungary & Germany & Italy & Finland & USA & $\begin{array}{c}\text { Overall } \\
\text { Mean } \\
\text { Rank }\end{array}$ & $\begin{array}{c}\text { Significance } \\
\text { Between } \\
\text { Countries }\end{array}$ \\
\hline Help Others & 4.59 & 3.83 & 4.02 & 4.40 & 4.79 & $\mathbf{4 . 3 2}$ & $\mathrm{P}=.00$ \\
\hline Feel Successful & 3.50 & 2.95 & 3.91 & 3.85 & 4.12 & 3.66 & $\mathrm{P}=.00$ \\
\hline $\begin{array}{l}\text { Earn a Lot of } \\
\text { Money }\end{array}$ & 2.62 & 2.25 & 1.95 & 2.05 & 2.10 & 2.19 & $\mathrm{P}=.00$ \\
\hline $\begin{array}{l}\text { Concern Myself } \\
\text { with People }\end{array}$ & 4.70 & 4.44 & 3.96 & 4.77 & 4.57 & $\mathbf{4 . 4 8}$ & $\mathrm{P}=.00$ \\
\hline $\begin{array}{l}\text { Gain Social } \\
\text { Esteem }\end{array}$ & 3.40 & 2.44 & 2.79 & 3.26 & 3.26 & 3.03 & $\mathrm{P}=.00$ \\
\hline
\end{tabular}

Table 5: I want to be a social worker to

Kruskal-Wallis Analysis of Ranks Test Utilized for Each Analysis.

Clearly all students irrespective of country want to be a social worker to (a) concern themselves with people (Mean Rank $=4.48$ ) and (b) to help others (Mean Rank $=4.32)$. It is most interesting that none of the groups believe that they will earn a lot of money as a social worker although the Hungarian students feel that professional training in social work will be more lucrative in their country than students from the other countries. Individual countries are significantly different on each question indicating social-cultural differences but overall patterns within the profession are still strong.

A parallel question was asked about why the profession of social work was attractive. Again the ratings were on a 1 to 5 scale with mutually exclusive questions.

\begin{tabular}{|l|c|c|c|c|c|c|c|}
\hline & Hungary & Germany & Italy & Finland & USA & $\begin{array}{c}\text { Overall } \\
\text { Mean } \\
\text { Rank }\end{array}$ & $\begin{array}{c}\text { Significance } \\
\text { Between } \\
\text { Countries }\end{array}$ \\
\hline $\begin{array}{l}\text { You Help } \\
\text { People }\end{array}$ & 4.59 & 3.93 & 4.02 & 4.49 & 4.79 & $\mathbf{4 . 3 6}$ & $\mathrm{P}=.00$ \\
\hline $\begin{array}{l}\text { You Can Feel } \\
\text { Successful }\end{array}$ & 3.50 & 2.85 & 3.91 & 3.85 & 4.12 & $\mathbf{3 . 6 7}$ & $\mathrm{P}=.00$ \\
\hline $\begin{array}{l}\text { Work with } \\
\text { People }\end{array}$ & 4.70 & 4.44 & 3.82 & 4.69 & 4.56 & $\mathbf{4 . 4 4}$ & $\mathrm{P}=.00$ \\
\hline $\begin{array}{l}\text { Earn a Lot of } \\
\text { Money }\end{array}$ & 2.62 & 2.25 & 1.95 & 2.05 & 2.09 & $\mathbf{2 . 1 9}$ & $\mathrm{P}=.00$ \\
\hline $\begin{array}{l}\text { Profession is } \\
\text { Highly } \\
\text { Regarded }\end{array}$ & 3.40 & 2.44 & 2.79 & 2.83 & 3.26 & $\mathbf{2 . 9 4}$ & $\mathrm{P}=.01$ \\
\hline
\end{tabular}

Table 6: The social work profession is attractive because Kruskal-Wallis Analysis of Ranks Test Utilized for Each Analysis. 
There are two salient reasons for all social work students as to why social work is attractive even though there is some difference in the amount of importance between countries (a) you help people (Mean Rank of 4.36) and (b) you work with people (Mean rank 4.44). All students recognize that the profession does not earn a lot of money (Mean Rank $=2.19$ ) while there is a perception that the profession is not highly regarded (Mean Rank $=2.94$ ), however you can feel successful in social work (Mean Rank $=3.67$ ).

The next table is a list of items that were presented to the students as things that a social worker needs to know to practice social work. Again, each item was rated independently on a scale from 1 to 5 with 1 being low and 5 being high.

\begin{tabular}{|l|c|c|c|c|c|c|c|}
\hline & Hungary & Germany & Italy & Finland & USA & $\begin{array}{c}\text { Mean } \\
\text { Rank }\end{array}$ & $\begin{array}{c}\text { Significance } \\
\text { Between } \\
\text { Countries }\end{array}$ \\
\hline Tolerant & 4.43 & 4.02 & 4.24 & 3.66 & 4.78 & 4.23 & $\mathrm{P}=.01$ \\
\hline $\begin{array}{l}\text { Put Self in } \\
\text { Others Position }\end{array}$ & 4.36 & 4.62 & 4.07 & 4.62 & 4.66 & 4.46 & $\mathrm{P}=.00$ \\
\hline $\begin{array}{l}\text { Communicate } \\
\text { Well }\end{array}$ & 4.80 & 4.38 & 4.67 & 4.69 & 4.86 & $\mathbf{4 . 6 8}$ & $\mathrm{P}=.00$ \\
\hline $\begin{array}{l}\text { Make Best of } \\
\text { Situation }\end{array}$ & 4.34 & 3.49 & 3.38 & 3.98 & 4.62 & 3.96 & $\mathrm{P}=.00$ \\
\hline $\begin{array}{l}\text { Know Legal } \\
\text { Issues }\end{array}$ & 4.35 & 4.23 & 4.13 & 4.25 & 4.53 & 4.30 & $\mathrm{P}=.00$ \\
\hline $\begin{array}{l}\text { Keep Distance } \\
\text { From Problems }\end{array}$ & 4.09 & 4.39 & 4.20 & 3.66 & 4.76 & 4.22 & $\mathrm{P}=.00$ \\
\hline $\begin{array}{l}\text { Know } \\
\text { Sociological } \\
\text { Issues }\end{array}$ & 4.25 & 3.98 & 4.60 & 4.11 & 4.50 & 4.28 & $\mathrm{P}=.00$ \\
\hline $\begin{array}{l}\text { Be Able to } \\
\text { Start Over }\end{array}$ & 4.40 & 3.83 & 4.11 & 4.05 & 4.64 & 4.20 & $\mathrm{P}=.00$ \\
\hline $\begin{array}{l}\text { Socio- } \\
\text { Politically } \\
\text { Informed }\end{array}$ & 4.21 & 3.93 & 4.04 & 4.26 & 4.55 & 4.20 & $\mathrm{P}=.00$ \\
\hline
\end{tabular}

Table 7: A social worker has to learn

Kruskal-Wallis Analysis of Ranks Test Utilized for Each Analysis.

All of the items presented about what a social worker needs to learn were very high for students from all countries. The ability to communicate well (Mean Rank $=4.68)$ and to be able to put yourself in another's position $($ Mean Rank $=$ 4.46) were rated the most important. Also between all countries it was seen that 
there are cultural/national differences for example tolerance rated low by the Finish students (Mean Rank = 3.66) compared to the others and making the best of the situation (Mean Rank 3.38) being rated lowest by the Italian students.

Characteristics important to a social worker were also rated. As shown in the next table all of the characteristics were viewed as important except being attractive. Some of the characteristics were seen as very critical to practice. Professional preparation (Mean Rank 4.60) was the most important characteristic indicating that irrespective of country to be a competent social worker one must have professional training in a program of social work. Numerous other personal characteristics, empathy (Mean Rank 4.41), resourcefulness (Mean Rank 4.10), creative (Mean Rank 4.13), and sensitive (Mean Rank 4.34) were all rated high as qualities social workers should possess. All countries rated attractiveness (Mean Rank = 2.52) as not being important with the exception of Finland (Mean Rank = 3.78) and it was not rated very high by them.

\begin{tabular}{|l|c|c|c|c|c|c|c|}
\hline & Hungary & Germany & Italy & Finland & USA & $\begin{array}{c}\text { Mean } \\
\text { Rank }\end{array}$ & $\begin{array}{c}\text { Significance } \\
\text { Between } \\
\text { Countries }\end{array}$ \\
\hline Empathy & 4.85 & 4.21 & 4.09 & 4.12 & 4.79 & 4.41 & $\mathrm{P}=.00$ \\
\hline $\begin{array}{l}\text { Professional } \\
\text { Preparation }\end{array}$ & 4.82 & 4.35 & 4.52 & 4.60 & 4.71 & $\mathbf{4 . 6 0}$ & $\mathrm{P}=.00$ \\
\hline Sensitive & 4.00 & 4.10 & 4.21 & 3.60 & 4.79 & 4.34 & $\mathrm{P}=.00$ \\
\hline Unselfish & 3.58 & 1.92 & 3.61 & 3.09 & 3.70 & 3.22 & $\mathrm{P}=.00$ \\
\hline Resourceful & 4.55 & 3.95 & 4.07 & 3.92 & 4.02 & 4.10 & $\mathrm{P}=.00$ \\
\hline Attractive & 2.86 & 1.90 & 1.68 & 3.78 & 2.38 & $\mathbf{2 . 5 2}$ & $\mathrm{P}=.00$ \\
\hline Creative & 4.16 & 3.87 & 4.11 & 4.05 & 4.36 & 4.13 & $\mathrm{P}=.00$ \\
\hline $\begin{array}{l}\text { School } \\
\text { Attendance }\end{array}$ & 3.40 & 2.44 & 2.79 & 2.83 & 3.26 & 2.94 & $\mathrm{P}=.01$ \\
\hline
\end{tabular}

Table 8: Characteristics important to a social worker Kruskal-Wallis Analysis of Ranks Test Utilized for Each Test.

Students were also asked why the profession of social work could be difficult. Again the question is somewhat parallel to why social work is attractive but asked the student to identify what are the most difficult parts of being a social worker. There was a lot of consistency in the answers with students identifying experiences wearing you out (Mean Rank of 3.69) and earning little money (Mean Rank of 3.58) as the most salient reasons for the profession being a difficult one. The other reasons were seen as contributing less to the profession being a difficult one. It needs to be stated that none of the reasons ranked very high or reached a Mean Rank of 4.0 compared to the reasons for the profession being attractive where many reached a Mean Rank value of 4.0. 


\begin{tabular}{|l|c|c|c|c|c|c|c|}
\hline & Hungary & Germany & Italy & Finland & USA & $\begin{array}{c}\text { Overall } \\
\text { Mean } \\
\text { Rank }\end{array}$ & $\begin{array}{c}\text { Significance } \\
\text { Between } \\
\text { Countries }\end{array}$ \\
\hline $\begin{array}{l}\text { Full of } \\
\text { Failure }\end{array}$ & 3.42 & 3.41 & 2.56 & 2.37 & 2.98 & 2.95 & $\mathrm{P}=.00$ \\
\hline $\begin{array}{l}\text { People are } \\
\text { Ungrateful }\end{array}$ & 2.42 & 2.62 & 1.96 & 2.42 & 2.72 & 2.43 & $\mathrm{P}=.000$ \\
\hline $\begin{array}{l}\text { Experiences } \\
\text { Wear you } \\
\text { Out }\end{array}$ & 3.50 & 3.19 & 3.32 & 4.26 & 4.19 & $\mathbf{3 . 6 9}$ & $\mathrm{P}=.00$ \\
\hline $\begin{array}{l}\text { Earn Little } \\
\text { Money }\end{array}$ & 3.56 & 3.51 & 2.91 & 3.58 & 4.32 & $\mathbf{3 . 5 8}$ & $\mathrm{P}=.00$ \\
\hline $\begin{array}{l}\text { You are } \\
\text { Disregarded }\end{array}$ & 3.06 & 3.35 & 3.25 & 3.32 & 3.82 & 3.36 & $\mathrm{P}=.01$ \\
\hline
\end{tabular}

Table 9: The profession of social work is difficult because Kruskal-Wallis Analysis of Ranks Test Utilized for Each Test.

It is important to determine what professions are seen by potential professional social workers as being like their chosen profession. A list of various professions was developed some that were deemed to be similar to social work and some that were not. Again the categories were ranked on a 1 to 5 scale. As shown in the table the Mean Ranks of psychologist (3.69) teacher (3.56) and supervisor (3.45) were rated as most closely resembling the work of a social worker. The Mean Ranks of those most different from social worker were engineer (1.61) and lawyer (2.76). There were some interesting differences between the countries in rankings. The Italian students had a Mean Rank for priest (1.84) and nurse (1.73) very different from compared to all the other countries. This disparity may be explained when a comparison is made between the view by the Roman Catholic Church in Italy toward divorce and abortion and the view held by most of the social work profession. All the other professions were rather similar from country to country. 


\begin{tabular}{|l|c|c|c|c|c|c|c|}
\hline & Hungary & Germany & Italy & Finland & USA & $\begin{array}{c}\text { Mean } \\
\text { Rank }\end{array}$ & $\begin{array}{c}\text { Significance } \\
\text { Between } \\
\text { Countries }\end{array}$ \\
\hline Psychologist & 3.93 & 3.79 & 3.05 & 4.06 & 3.60 & $\mathbf{3 . 6 9}$ & $\mathrm{P}=.00$ \\
\hline Lawyer & 2.90 & 3.21 & 2.18 & 2.69 & 2.82 & $\mathbf{2 . 7 6}$ & $\mathrm{P}=.00$ \\
\hline Priest & 3.42 & 3.06 & $\mathbf{1 . 8 4}$ & 3.58 & 3.55 & $\mathbf{3 . 0 9}$ & $\mathrm{P}=.00$ \\
\hline Teacher & 3.06 & 4.22 & 2.59 & 4.09 & 3.82 & $\mathbf{3 . 5 6}$ & $\mathrm{P}=.00$ \\
\hline Economist & 1.83 & 2.68 & 1.57 & 1.92 & 2.40 & $\mathbf{2 . 0 8}$ & $\mathrm{P}=.00$ \\
\hline Engineer & 1.50 & 1.81 & 1.25 & 1.62 & 1.85 & $\mathbf{1 . 6 1}$ & $\mathrm{P}=.00$ \\
\hline Supervisor & 3.65 & 3.79 & 3.11 & 3.45 & 3.25 & $\mathbf{3 . 4 5}$ & $\mathrm{P}=.04$ \\
\hline Nurse & 2.93 & 3.90 & $\mathbf{1 . 7 3}$ & 3.55 & 3.11 & $\mathbf{3 . 0 4}$ & $\mathrm{P}=.00$ \\
\hline
\end{tabular}

Table 10: Professions most like social work Kruskal-Wallis Analysis of Ranks Test Utilized for Each Test.

It is interesting to note that the students did not see any of the professions being very similar to social work with the highest rating being given to psychologist (Mean Rank 3.69) as most closely resembling what social workers do. All other professions were in the average range of relationship to social work with an economist (Mean Rank 2.08) being the least like social work.

Another related question to what professions are like social work is the question what other professions are social workers most likely to collaborate with. As we have seen the psychologist is not only the most like social work, it is the profession that is seen as more likely to collaborate with (Mean Rank 4.25). The other professions rated by all countries as most likely to collaborate with social work are supervisors (Mean rank 3.98), sociologists (Mean Rank 3.83), teachers (Mean Rank 3.69) and doctors (Mean Rank 3.45). The professions least likely to collaborate with are engineers (Mean Rank 1.91), economists (Mean Rank 2.39), politician (2.50), and artists (Mean Rank 2.69). It is also consistent in that the same finding concerning the students from Italy with respect to their view about priests, and nuns being different from social work also is found in that the Italian students don't see much collaboration with these two professions. Also the Italian students rated nurses as unlikely to collaborate with compared to the other countries and this may be attributed to many nurses in Italy being nuns. 


\begin{tabular}{|l|c|c|c|c|c|c|c|}
\hline & Hungary & Germany & Italy & Finland & USA & $\begin{array}{c}\text { Mean } \\
\text { Rank }\end{array}$ & $\begin{array}{c}\text { Significance } \\
\text { Between } \\
\text { Countries }\end{array}$ \\
\hline Psychologist & 5.43 & 3.87 & 3.55 & 4.48 & 3.91 & $\mathbf{4 . 2 5}$ & $\mathrm{P}=.00$ \\
\hline Lawyer & 3.32 & 3.43 & 2.82 & 2.86 & 3.30 & 3.15 & $\mathrm{P}=.00$ \\
\hline Priest & 3.39 & 2.92 & 2.20 & 3.93 & 3.95 & 3.28 & $\mathrm{P}=.00$ \\
\hline Teacher & 3.62 & 3.44 & 3.05 & 4.23 & 4.11 & $\mathbf{3 . 6 9}$ & $\mathrm{P}=.00$ \\
\hline Economist & 2.46 & 2.76 & 1.88 & 2.09 & 2.77 & $\mathbf{2 . 3 9}$ & $\mathrm{P}=.00$ \\
\hline Engineer & 1.79 & 2.02 & 1.48 & 1.94 & 2.32 & $\mathbf{1 . 9 1}$ & $\mathrm{P}=.00$ \\
\hline $\begin{array}{l}\text { Supervisor/ } \\
\text { manager }\end{array}$ & 4.27 & 3.81 & 3.63 & 4.05 & 4.12 & $\mathbf{3 . 9 8}$ & $\mathrm{P}=.25$ \\
\hline Doctor & 3.50 & 3.44 & 2.98 & 3.80 & 3.51 & $\mathbf{3 . 4 5}$ & $\mathrm{P}=.06$ \\
\hline Police & 3.36 & 2.89 & 2.29 & 3.92 & 3.67 & 3.23 & $\mathrm{P}=.12$ \\
\hline Artist & 2.58 & 3.13 & 1.75 & 2.88 & 3.09 & $\mathbf{2 . 6 9}$ & $\mathrm{P}=.00$ \\
\hline Journalist & 3.21 & 3.08 & 2.14 & 2.46 & 3.02 & 2.78 & $\mathrm{P}=.00$ \\
\hline Judge & 3.12 & 3.14 & 3.13 & 2.77 & 3.58 & 3.15 & $\mathrm{P}=.00$ \\
\hline Nun & 2.91 & 2.48 & 2.21 & 2.58 & 3.77 & 2.79 & $\mathrm{P}=.00$ \\
\hline Politician & 2.84 & 2.62 & 2.29 & 2.29 & 2.48 & $\mathbf{2 . 5 0}$ & $\mathrm{P}=.22$ \\
\hline Sociologist & 4.08 & 3.62 & 3.40 & 3.92 & 4.11 & $\mathbf{3 . 8 3}$ & $\mathrm{P}=.04$ \\
\hline Nurse & 2.93 & 3.90 & 1.73 & 3.55 & 3.11 & 3.04 & $\mathrm{P}=.00$ \\
\hline
\end{tabular}

Table 11: Professions that most collaborate with social work Kruskal-Wallis Analysis of Ranks Test Utilized for Each Test.

The final section of the survey was a group of 45 (revised from scale developed by Super) questions to which the student replied on a 5-point scale from strongly disagree to strongly agree. These questions were designed to elicit their viewpoint about characteristics that they consider important to a satisfying job. These questions were included in an effort to first find factors that could be developed into scales that could be used as job desirable job characteristics. The second question was to see if these scales could be used to discriminate between students from different countries.

The 45 questions were factor analyzed which resulted in 8 factors that were then forced into 4 factors. At this point one question was deleted from the 45 questions, as it did not fit into the four forced factors. Then 4 items in each of the 4 factors were identified with the highest loading into the "top 4". These "top 4" in the four factors were then analyzed to see if there was an interpretative theme between and among the "top 4" in each factor. The themes were established as mutually exclusive and items were added to each factor that matched the theme of the "top 4" for each group. While making these groupings it was seen that three of the themes were really closely connected thus a second order analysis was conducted to determine if there was a "super factor" which was confirmed. Then 
each of the 4 scales was tested for reliability. Item correlations within each scale were conducted and a few with low inter item correlations were deleted. The final result was four scales as shown in the appendix.

The theme of Scale 1 (Cronbach alpha $=.94$ ) was "I want a job that is creative, challenging, with a variety of tasks that allows me to see results" and consisted of 17 items. Scale 2's theme was "I want a job that provides a feeling of accomplishment" and consisted of 8 items (Cronbach alpha $=.86$ ). "I want a job that is secure" was the theme of Scale 3 with 6 items (Cronbach alpha $=.79$ ). The last, Scale 4, was made up of 5 items with the theme "I want to help others within the context of a job that offers professional advancement" (Cronbach alpha $=.82$ ).

The total score for each scale varied with the number of questions in the scale. For each question the range was from 1 not important to 5 very important so that a high score indicated that these items on the scale and therefore the theme was very important to the student. Scale 1's total possible score $=85$, average ranking $=51$; Scale 2's total possible score $=40$, average ranking $=24$; Scale 3's total possible score $=30$, average ranking $=18$; Scale 4's total possible score $=25$, average ranking $=15$. Some very interesting results occur when looking at the result of the differences between countries on preferences for job. As shown in Scale 1 "I want a job that is creative, challenging, has a variety of tasks and can see results", there are significant differences between the five countries $(\mathrm{F}=21.27, \mathrm{df}=4, \mathrm{p}=.000)$. Italian students have an average interest in having this kind of job (53), while Hungarian (71) and U.S. (69) students are the most desirous of a job having these qualities.

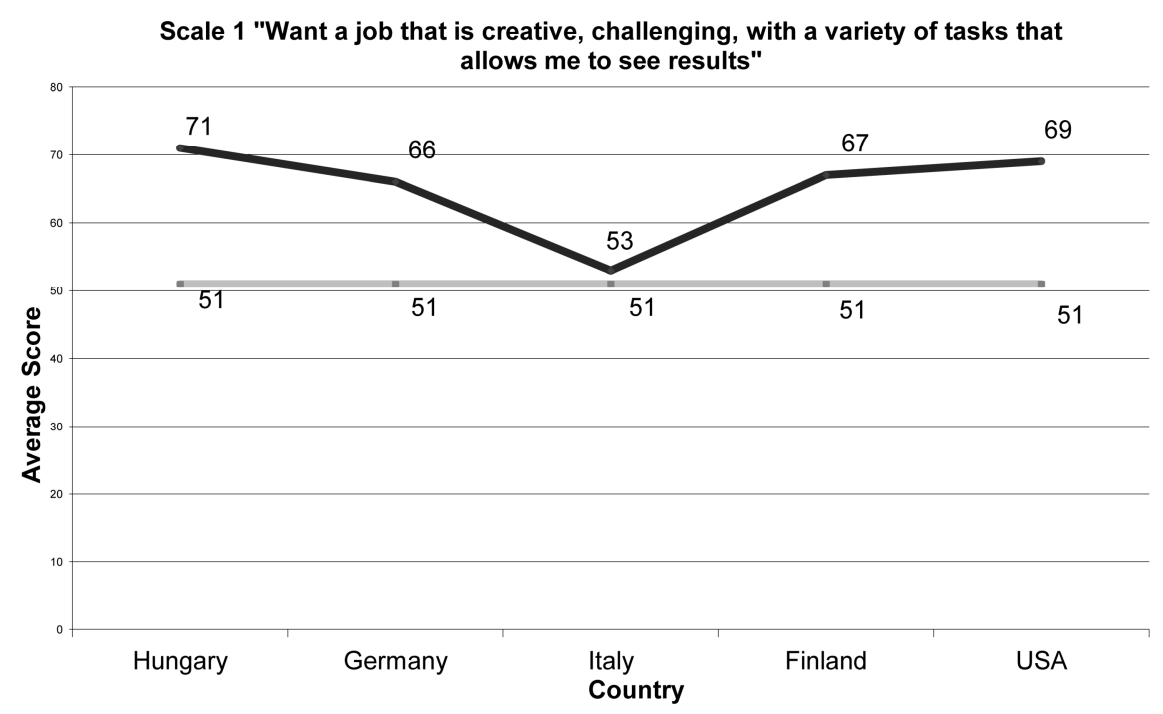

Chart 4: Scale 1 by country. 
The data from Scale 2 "Want a job that provides a feeling of accomplishment" demonstrates the significant difference $(\mathrm{F}=50.17 \mathrm{df}=4, \mathrm{p}=.000)$ in that both the American (31) students and German (32) students are well above average interest in this aspect of a job compared to an average interest by the Italian (24) Hungarian (22) and Finish (21) students

Scale 2 "Want a job that provides a feeling of accomplishment"

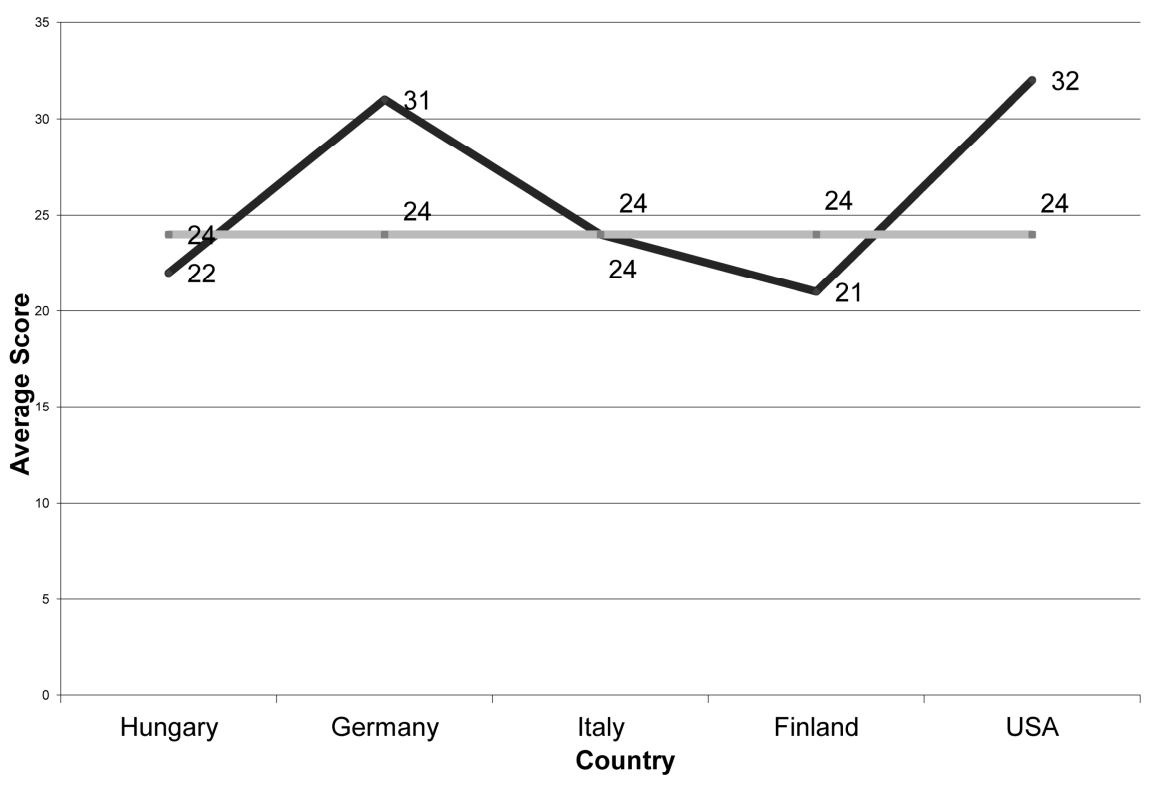

Chart 5: Scale 2 by country.

Scale 3 incorporates the theme that the student "Wants a job that is secure". Once again we see the similarity and above average interest in this job aspect between the American (24) German (22) and this time also the Hungarian (21) students which is significantly different $(\mathrm{F}=19.48 \mathrm{df}=4 . \mathrm{p}=.000)$ from the Italian and Finish students. The Italian (17) and Finish (18) students do not seem as concerned about job security as the students from the other three countries reflecting average concern about this aspect of the job. 
Scale 3 "Want a job that is secure"

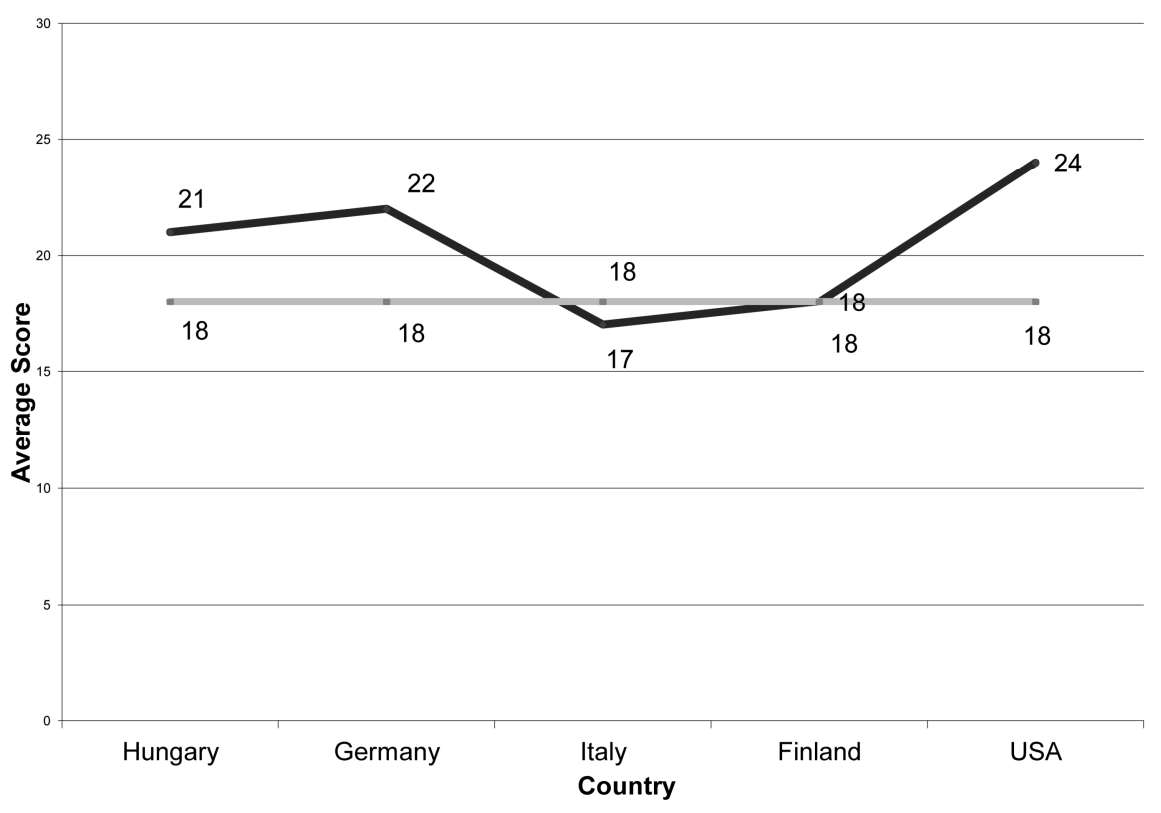

Chart 6: Scale 3 by country.

The last scale, Scale 4, measures the idea that the student "Wants a job to help others" and that provides professional advancement. What is interesting with this aspect of the job is that all students (Hungarian $=20$, Germany $=17$, Finish $=$ 17, and American =21) with the exception of the Italian students (14) valuing this characteristic very highly. The Hungarians and Americans in particular place high importance on this job characteristic. There were some significant differences $(\mathrm{F}=37.30, \mathrm{df}=4, \mathrm{p}=.00)$. 


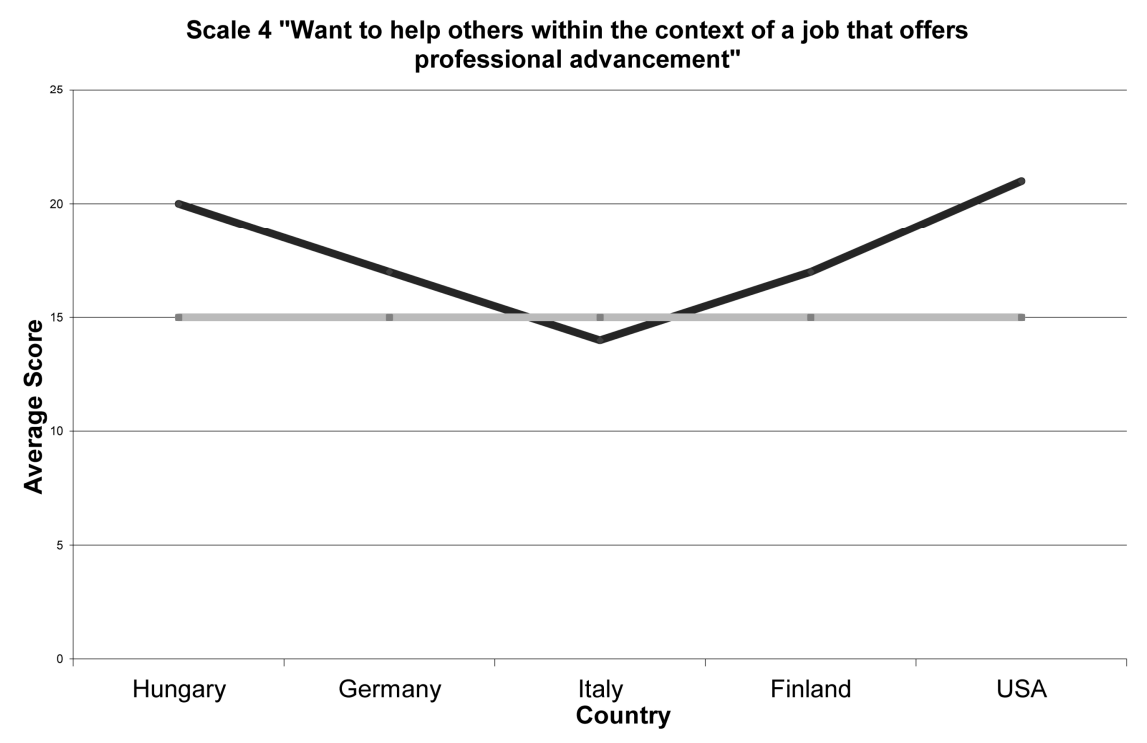

Chart 7: Scale 4 by country.

The overall results of the characteristics of the job most preferred by the students of each country can be summarized as follows:

"Want a job that is creative, challenging, with a variety of tasks and can see results."

Hungary and the USA see these characteristics as very important Germany and Finland see them as important

Italy has about an average concern for these characteristics in a job

\section{"Want a job that provides a feeling of accomplishment."}

Germany and USA view the need for accomplishment as very important Hungary, Finland and Italy see it as being of average importance

\section{"Want a job that is secure."}

The USA sees a secure job as very important

Germany and Hungary see it as important

Finland and Italy view it as having average importance 


\section{"Want a job that I can help others and provides professional advancement."}

Hungary and the USA feel that this is highly important

Germany and Finland see it as important

Italy views it as having average importance.

Given that the scales were reliable and that there were significant differences between the various countries on the scales it was decided to attempt to utilize the scale scores for a given individual to predict country of origin. Utilizing discriminate analysis the following results were obtained:

OVERALL:

$62 \%$ of all students were correctly classified into their home country using.

Four scales compared to $20 \%$ by chance classification.

\section{HUNGARY}

$79 \%$ Correctly Classified.

Most like Finish students with 15\% misclassified as Finish.

Least like German students with $0 \%$ classified as German.

\section{GERMANY}

67\% Correctly Classified.

Most like American students with 19\% misclassified as American.

Least like Finish students with 3\% classified as Finish.

\section{ITALY}

$41 \%$ Correctly Classified.

Most like German students with 37\% classified as German.

Least like Hungarian students with $4 \%$ classified as Hungarian.

\section{FINLAND}

$38 \%$ Correctly Classified.

Most like Hungarian students with 47\% classified as Hungarian.

Least like American, German, and Italian with 5\% classified as

Each country.

\section{AMERICAN}

$69 \%$ Correctly Classified.

Most like German students with $14 \%$ classified as German.

Least like Italian students with $2 \%$ classified as Italian. 


\section{Conclusions}

The most striking finding is while there are differences between the countries with respect to all the variables, there is a very high degree of similarity or agreement between the countries. For example, one of the characteristics that is important to the profession of social work - empathy - was rated very important (between 4.09 and 4.85 ) by students from all countries even though there was a significant difference between the countries. Another example would be why the students wanted to be social workers - to help others - again rated very important by all students although statistically there were significant differences between countries. Cultural differences are in evidence when the social work students from Italy rated working with priests and nuns low compared to other countries. This difference appears to be the Italian student's perception of a difference between social work and the church on matters of abortion and divorce.

Finally, a series of four scales were developed that measure job characteristics which are highly reliable for social work students. These scales can be used to discriminate between students from different countries in that students from different countries have different preferences in their most desired job characteristics.

\section{APPENDIX}

FINAL SCALES

SCALE 1 QUESITONS "Want a job that is creative, challenging, with a variety of tasks that allows
me to see results."

Q4 Variety of changes within the job.

Q5 Freedom in your area of responsibility.

Q6 Gain prestige in your profession.

Q10 Can be true to yourself.

Q15 Try new ideas and suggestions.

Q 16 Create something new.

Q17 See positive results.

Q21 Make your own decisions.

Q23 Challenged mentally.

Q24 Use leadership abilities.

Q27 Friendship with fellow employees. 
Q29

Q32

Q35

Q38

Q44

Q45

Variety of tasks.

Do many different things.

Lead the kind of life you most enjoy.

Need to be mentally alert.

See the results of your efforts.

Contribute new ideas.

\section{SCALE 2}

\section{"Want a job that provides a feeling of accomplishment."}

Q1 Opportunity to solve new problems.

Q9 Know your job will last.

Q11 Respectful boss.

Q13 Daily feeling of accomplishment.

Q19 Sure of always having a job.

Q25 Adequate lounge, toilet and facilities.

Q26 Have a satisfying life when not working.

Q36 Have a good working space.

\section{SCALE 3}

\section{"Want a job that is secure."}

Q8 Sense of belonging.

Q18 Reasonable boss.

Q22 Pay that keeps up with the cost of living.

Q33 Looked up to by others.

Q34 Good contacts with fellow workers.

Q39 Paid enough to live right.

\section{SCALE 4}

"Want to help others within the context of a job that offers professional advancement."

Q2 Help others.

Q3 Opportunity for a raise.

Q20 Add beauty to the world.

Q30 Feeling that you have helped others.

Q31 Add to the well being of other people. 


\section{References}

1. Fábián G. - Fónai M. (1999): Szociális munkás szakos hallgatók pályaképének nemzetközi összehasonlítása. Peremvidék. Szociális kutatások Szabolcs-Szatmár-Bereg megyében. Szerk.: Lukácskó Zsolt-Fónai MihályFábián Gergely. DOTE Egészségügyi Főiskolai Kar, Nyíregyháza-Népjóléti Képzési Központ, Salgótarján. 219-251.

2. Fónai M. - Kiss J. - Fábián G.(1999): Szociális munkás szakos hallgatók pályaképének néhány eleme. Esély 1. 114-134.

3. Fónai M. - Kiss J. - Fábián G. (2001): A szociális munkás szakos hallgatók pályaképe: a professzió sztenderdjei és a nemzeti-kulturális változó. Multikulturalizmus és oktatás (Szerk.: Kiss Gabriella), MTA DAB - DE Szociológia Tanszék, Debrecen. 75-93.

4. Super D.E. (1957): The Psychology of Careers. Harper, New York.

5. Super D.E. (1995): Life Roles, Values and Careers. San Francisco, Jossey Bass.

Gergely Fabian Ph.D.: Professor and vice dean of Health Faculty of University of Debrecen

Department of Applied Social Sciences of Health Faculty, University of Debrecen Nyíregyháza, Hungary

Thomas R. Lawson Ph.D.: Hon Dr. Sci. Professor and Director of International Programs

Kent School of Social Work, University of Louisville

Louisville, Kentucky USA

Mihaly Fonai Ph.D.: Associated professor and vice dean of Law Faculty of Debrecen

Department of Philosphy Sociology of Law

University of Debrecen, Debrecen, Hungary

Janos Kiss Ph.D.: Associated professor

Department of Applied Psychology of Health Faculty

University of Debrecen, Nyíregyháza, Hungary

Eric. R. Soelter: L.C.S.W., Ph.D. Healthcare Consultant

Kent School of Social Work

University of Louisville, Louisville, Kentucky USA 


\section{UNIVERSITY \\ of DEBRECEN \\ FACULTY OF \\ HEALTH}

NYÍREGYHÁZA

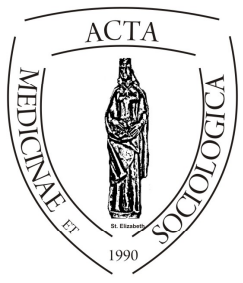

ACTA

MedSoc

VOLUME 5.

2014

\title{
Segítői hivatásra készülő hallgatók coping stratégiáinak megnyilvánulási lehetőségei nehéz, szakmai helyzetek kezelése során
}

\author{
Oroszné Pál Zsuzsanna - Sárváry Andrea \\ Debreceni Egyetem, Egészségügyi Kar
}

\begin{abstract}
We have taught helping students at the University of Debrecen, Faculty of Health for a number of years. Our goal is to train professionals who are competently and effectively carry out their work. In our survey we examine the students' mental health, career motivation, ideas their of the profession, their image of the profession and the skills influencing helping professions skills. The results of this research will be used for the purpose of effective skills development

The helping profession training system includes theoretical knowledge and practical skills, in addition important personality development of the profession (Bagdy E., 1996). For example: empathy, congruent communication, communication awareness, aggression management etc). Training help professionals it also important to achieve a healthy mental status, effective mental capacity as well. Student's career, future career motivation and their mental health status affect the training modules and tailor made trainings.

In the higher education training we have witnessed a significant transformation which is not conducive to training requirements to support the development of personal skills. Over the past two decades, student's expectations towards higer education and motivations have changed, there appeared the postadolescence generations as well.

Our paper is presented as a part of this larger-scale research, which includes the concept of coping, the knowledge of the profession and the image of the profession.
\end{abstract}


We review some previous research on the topic of coping, describing the concept and factors affecting the phenomenon. We determined the students' coping strategies. The results showed that problem-focused coping is the dominant mode, which on the one hand helps in the efficient solution of everyday professional situations, on the other hand it makes the proper management of the emotional situations more difficult. We present the correlations between the coping mechanisms and the professional's career and professional roles. We asked about factors affecting the profession skills, capabilities, advantages and disadvantages, which determine the choice of profession. We analyzed the responses in connection with the difficult, occupational situations. The analysis of the results showed that rational problem solving mode is manifested in students' solutions but this is less consciously, more instinctively. There are few effective means to solve problems, their solution methods show a simple scheme. They are motivated by the support, and they have appropriate empathy and care, which can be built by a controlled and focused facilitator conduct.

Keywords: higher education, mental health status, health psychology, coping strategies, career profiles

Összefoglalás. A Debreceni Egyetem Egészségügyi Karán segítő hivatásra készülő hallgatók oktatásában több éve veszünk részt. Célunk olyan szakemberek képzése, akik kompetensként, hatékonyan látják el munkájukat. Kutatásunk során feltérképezzük a hallgatók mentális egészségét, pályaválasztási motivációját, szakmáról való elképzeléseit, szakmai hivatást, hatékony segítői munkát befolyásoló készségeket, képességeket. A kutatás eredményeit a hatékony készségfejlesztés céljára használjuk fel.

A segítő szakmák képzésében a teoretikus tudást és gyakorlati rutint nyújtó (specifikus) tárgyak mellett fontos az ún hivatásszemélyiség (Bagdy E., 1996) fejlesztése. A segítő szakmák esetében pl. empátia, kongruens kommunikáció, kommunikációs tudatosság, agressziókezelés stb, valamint az egészséges mentális státusz, a hatékony pszichés terhelhetőség megvalósítása. A képzési modulok, tréningek egyénekre szabott jellegét befolyásolja a hallgatók pályaképe, pályamotivációja, valamint mentális egészségi állapotuk

A felsőoktatási képzésben jelentős átalakulásoknak vagyunk tanúi, melyek nem kedveznek azon képzési követelményeknek, melyek a szakmai és személyes képességek, készségek fejlődését, fejlesztését segítik elő. Az elmúlt két évtizedben a hallgatói elvárások, motivációk is megváltoztak a felsőoktatással szemben, valamint megjelent a posztadolescens nemzedéke.

Cikkükben ennek a nagyobb volumenü kutatásnak egy részét mutatjuk be, mely során elötérbe kerül a coping fogalma és a szakmáról szerzett ismeretek, és a pályakép jellegzetességei.

Ismertetünk néhány korábbi kutatást a coping témaköréből, mely során tisztázzuk a fogalmat és a jelenséget befolyásoló tényezőket. A hallgatóink coping-stratégiáinak beazonosítása megmutatta, hogy a problémafókuszú megküzdési mód a domináns, mely egyrészt segítséget jelent a mindennapi professzionális helyzetek hatékony megoldásában, másrészt nehezíti az érzelmi helyzetek megfelelő kezelését. A megküzdési módok és a szakmai pályakép, szerep összefüggéseinek bemutatására is vállalkozunk. Megkér- 
deztük a hivatást befolyásoló készségeket, képességeket, előnyöket, hátrányokat, melyek meghatározzák a hivatásválasztást. Nehéz hivatásbeli helyzetekre adott válaszreakciók elemzése arra mutatott rá, hogy hallgatóink problémamegoldásai során a racionális megoldásmód túlsúlya érvényesül, ám ezt kevésbé tudatos szinten, inkább ösztönösen teszik. Kevés eszközzel rendelkeznek a hatékony problémamegoldásra, megoldásmódjaik sémaszerủek. Motiváltak a segítésre, a megfelelő empátiás készséggel, odafigyeléssel rendelkeznek, melyre építhető egy irányított, koncentrált segítői magatartás.

Kulcsszavak: felsőoktatás, mentális státusz, egészségpszichológia, coping stratégiák, pályakép

\section{Bevezetés}

A Debreceni Egyetem Egészségügyi Karán több évtizede folyik a segítő hivatásra készülő hallgatók oktatása. Szociális munkás, védőnő, mentőtiszt, ápoló szakemberek lesznek hallgatóink. Célunk, hogy leendő szakemberként kompetens, hatékony módon lássák el munkájukat, de célunk az is, hogy sikeres, önmagát ismerő, és megfelelő megküzdési képességekkel rendelkező személyiségekké váljanak, hogy saját mentális egészségüket is megőrizhessék.

Napjaink megváltozott társadalmi, gazdasági struktúrájában a segítő hivatás kérdésköre is átalakulóban van. Egyre nagyobb szükség van ilyen szakemberekre, egyre tágabb feladatkörrel, mentális és fizikai leterheléssel, és egyre kevesebb lehetőséggel a szakma hatékony végzéséhez. Kopp Mária és munkatársainak kutatásai (Kopp M. - Kovács M., 2006) is felhívják a figyelmet a magyar lakosság általánosan rossz népegészségügyi állapotára. A magatartásszabályozás zavaraira, a korai stressz, a krónikus stressz negatív hatásaira, a megküzdési stratégiák elégtelen müködésére, az értékrend, a társas kapcsolatok hiányosságaira.

Általánosan ismert tény, hogy a segítő hivatásúak körében nagyobb a burnout kockázata (Cartwright, 1979). Stresszforrásként említhetjük, hogy túl sok beteggel kell foglalkozniuk, kritikus döntéseket kell hozniuk, és a munkafeltételek nem mindenesetben való maximális teljesülése is komoly felelősséget ró rájuk. Kapcsolatuk a beteggel, klienssel és azok hozzátartozóival érzelmileg megterhelö, gyakran szomatikus, mentális állapotukat veszélyezteti. A mindennapi megterhelő fizikai és pszichés igénybevétel következtében az egészségügyi dolgozóknak kifejezetten kedvezőtlen az egészségi állapota, morbiditási és mortalitási mutatói, és körükben gyakori a pszichoszomatikus tüneteik előfordulása (Pikó, 2001; Molnár, 2002; Pikó, 2001). Saját vizsgálatainkban tapasztaltuk mentőtisztek esetében a kiégés nagyobb mértékét, és az egyre fiatalabb korosztály érintettségét (Posgai - Oroszné, 2012). Csabai és munkatársai (Csabai és Barta, 2000) arra hívják fel a figyelmet, hogy az általuk megkérdezett orvostanhallgatók har- 
mada gondolt már arra, hogy befejezi tanulmányait, 20\%-uk azért, mert nem tartja magát alkalmasnak a pályára. Margitics (2006) szubklinikus depresszió meglétét tárta fel föiskolai hallgatók esetében. Ezek az eredmények azt mutatják, hogy már a képzésben fontos a segítöi készségek, kompetenciák hatékony fejlesztése, hiszen a segítő munkában való sikeresség alapvetően befolyásolhatja a mentális állapotot, szomatikus egészséget.

A segítő szakmákra készülő hallgatók, a segítő szakmákban dolgozó szakemberek mentális egészségének vizsgálatára kevés figyelmet fordítunk az egészségügy különböző területein, a „frontvonalon” dolgozó segítőkre, akik nap, mint nap a betegek, kliensek között dolgoznak, kevésbé fókuszálunk. Pszichológiai szempontból egyrészt a segítő kapcsolat fogalomköre adhat magyarázatot arra, hogy miért fontos ezzel a problémával foglalkoznunk. Másrészt a hallgatói, a felsőoktatásban megjelenő változások késztetnek bennünket arra, hogy felhívjuk a figyelmet a korosztály jellegzetességeiből következő, mentális egészséget befolyásoló jelenségekre.

A segítő kapcsolat olyan, növekedést elöidéző folyamat, melynek tagjai és körülményei befolyásolják a gyógyulási folyamatot. Hiszünk a bálinti „kapcsolat, mint gyógyító tényező,, elvében. Bálint szerint az ápoló személyzet személyisége, viselkedése is „gyógyszernek” tekinthető (Molnár - Csabai, 2009). A mindennapi gyógyító munka során a beteg és a segítő szakember közötti interakciónak jelentős szerepe van a gyógyulás, gyógyítási folyamatban. Ez nagy felelősséget és nehéz emocionális és kognitív feladatot is ad az ápoló személyzetnek. Az utóbbi időben megváltoztak a szakemberek és betegek szerepviszonyai, egyre jobban előtérbe kerül a partnerségi viszony, és a betegek részéröl a széleskörü tájékoztatási igény.

A gyógyító szerep pályaszocializációja során ezért a szakmai ismeretek átadásán túl, fontos egy készség, képességrendszer fejlesztése, amely hatékonnyá, tudatossá teszi a segítő kapcsolati rendszer nem specifikus hatótényezőit. Ezek a mindenki számára ismert és elérhető készségek, mint az empátia, kommunikáció, konfliktuskezelés, türelem, stb. hatékony alkalmazása megkönnyíti a gyógyító munkát. Mind a beteg elégedettebb lesz, mind pedig a segítő kompetensebbnek érezheti magát.

Patterson és Eisberg (Bagdy, 1996) által megfogalmazott hatékony segítői tulajdonságok a következőek:

1. Intellektuális kompetencia (jó elméleti felkészültség és szüntelen önképzés)

2. Energia (testi-lelki-kapcsolati müködések energizáltsága)

3. Hajlékonyság, rugalmasság a kliens problémája határozza meg a teendőket, nem a segítő „mihez értése” (módszertani jártassága) 
4. „Nem módszer specifikus” humán segítő tényezők nyújtani tudása (együttérzés, támogatás, megerősítés, személyesség, odaforduló figyelem, ,jelenlét”, légkör, biztonságnyújtás, együttgondolkodás stb.)

5. Jóindulatú alapattitüd

6. Önismeret: Intra- interperszonális személyi(ségi) valamint módszertani technikai kompetencia egyensúlya / „személyesség” személyiség és tudományosság - felkészültség egyensúlya/

Ezen tulajdonságok nem megvalósíthatóak hatékony, egészséges, jól funkcionáló személyiség nélkül, hiszen a mindennapi gyógyító munka során az ápoló szakember a személyiségével vesz részt, annak minden előnyös, hátrányos, tudatos és tudattalan megnyilvánulásával. Ez hat a betegre, ebből nyeri az erőt, a biztonságot, segíti, vagy éppen hátráltatja a gyógyulási folyamatot. A beteggel folytatott közös munka alapja egy mentálisan kiegyensúlyozott szakember, aki kompetens szakmájában, és ennek eredményeképpen egészséges. A kompetencia elégtelen megélése vezethet szomatikus, mentális problémákhoz.

Éppen ezért tartjuk fontosnak a segítő szakmában dolgozó, és már az arra készülő szakemberek mentális egészségének megóvását, megkeresni azokat a tényezőket, amelyek ebben szerepet játszanak. Az egyéni hatékonyság, az énkompetenciák, megküzdési módok széleskörü megismerése adhat választ arra, hogy milyen protektív tényezők segíthetik a szakemberek mindennapjait. Ezen szakemberek mentális egészségének megőrzése kulcsfontosságú az egészségügy rendszerében.

A felsőoktatási képzésben jelentős átalakulásoknak vagyunk tanúi. Az elmúlt két évtizedben a hallgatói elvárások, motivációk is megváltoztak a felsőoktatással szemben, valamint megjelent a posztadolescens nemzedéke. Ez, az az életkor, amelyet a szakirodalom az életkor feladataival összhangban többek között emering adulthood-nak (készülödő felnőttség) (Arnett, 2007), „the boomerang age”-nek (Mitchell, 2007) neveznek. Ezek az elnevezések arra utalnak, hogy a serdülö és felnőttkor között létezik egy átmeneti időszak, ami leginkább a felsőoktatásban lévő és onnan kikerült fiatalokra jellemző. Nagy próbatétel számukra, és krízishelyzetként is értelmezhetö, hogy alkalmazkodniuk kell a bizonytalan emocionális, egzisztenciális létből származó nehézségekhez. A kapunyitási krízis jelensége ez, utalva ezzel az életciklus váltásból származó problémákra (Magyari, 2009). Bizonytalanná válik a pályaválasztás, párválasztás, családalapítás. Sokan a depresszió jeleit mutatják. Margitics (2006) vizsgálatában a főiskolai hallgatók esetén a szubklinikus depresszió fokozott jelenlétét találta, melynek okai között a belső kontroll, az egyéni életvezetési készségek hiányát is látta. Jellemzőek életvezetési, mentálhigiénés, szomatikus problémák, betegségek (Lisznyai, 2010). 


\section{Megküzdési (coping) stratégiák}

A pszichés stresszel és az életeseményekkel foglalkozó kutatók az ötvenes évektől vezették be a „coping” fogalmát. Az angol kifejezés (to cope) a megterhelésekkel való megbirkózást, legyürést vagy azokon úrrá levést jelenti.

Megküzdés alatt a személy azon erőfeszítéseit értjük, melyek arra irányulnak, hogy legyőzze a rá ható külső vagy belső fenyegetéseket. A megküzdés (coping) olyan viselkedéses és intrapszichés mechanizmusokat tartalmaz, melyek segítségével a személy kezelni (megoldani, tolerálni, csökkenteni) tudja a környezeti és belső kihívásokat és a köztük előforduló konfliktusokat (Lazarus és Launier, 1978). A megküzdési folyamat révén az a személy új készségeket, képességeket sajátíthat el, vagyis a stressz hatékony megküzdése hosszabb távon pozitívnak tekinthető, hiszen fejlődéshez segítette hozzá az egyént.

A megküzdési stratégiáknak két főbb formája van (Lazarus, 1991a,b; Lazarus és Folkman, 1984). Az problémaközpontú megküzdés esetében a személy a problémára vagy a helyzetre összpontosítva megpróbálja azt megváltoztatni, illetve a jövőben elkerülni, vagy önmagát próbálja megváltoztatni, fejleszteni.

Az érzelemközpontú megküzdés esetében a személy nem képes közvetlenül a problémával foglalkozni, hanem tudatos vagy tudattalan (pl. elhárító mechanizmusok) stratégiákkal a helyzethez kapcsolódó érzelmi reakciókat igyekszik csökkenteni, ezáltal önmagát feszültségmentesíteni. Ez a stratégia különösen akkor hatékony, ha a személy magát a helyzetet nem képes megváltoztatni, vagy a helyzet eseményei befolyásolhatatlanok.

Az emberek többsége egyaránt használ problémaközpontú és érzelemközpontú megküzdési formákat (lásd még: Atkinson és mtsai, 1997; V. Komlósi, 2000). A különböző stresszhelyzetekhez való leghatékonyabb alkalmazkodás akkor várható az adott személytől, ha minél többféle megküzdési készséggel rendelkezik, és rugalmasan tudja ezeket használni a helyzet követelményeinek megfelelően, akár többet is egyszerre. A stratégiák hatékony alkalmazása függ az egyén korábbi tapasztalataitól, intellektuális képességeitől és önkontrolljától.

\section{A problémaközpontú megküzdés}

Ezt a stratégiát akkor választja az egyén, amikor úgy érzi, hogy van esélye befolyásolni a fennálló vagy fenyegető stresszhelyzetet. A személy arra összpontosít, hogy megkísérelje elkerülni, vagy megváltoztatni a fennálló, számára fenyegető helyzetet. 
Problémaközpontú megküzdéskor először a személy meghatározza a problémát, vagyis végiggondolja, hogy mi okoz számára nehézséget. Ezután számbaveszi a megoldási lehetőségeket, és mérlegeli azok előnyeit és hátrányait. Végül kiválasztja a számára leghatékonyabbnak tűnő megoldást, és végrehajtja.

Ezek a stratégiák irányulhatnak kifelé, a környezet felé, vagyis amikor a személy a környezetében, a helyzetben igyekszik változást elérni. Irányulhatnak azonban befelé is, amikor a személy önmagában igyekszik valamit megváltoztatni (pl. módosítja az igényszintjét, új készségeket sajátít el stb.).

A problémaközpontú megküzdésnek leggyakoribb módjai:

- tárgyalás: az egyén a helyzet többi résztvevőjére próbál hatást gyakorolni (pl. mások meggyőzése, kompromisszumra való törekvés),

- cselekvés: az egyén a probléma megoldására tesz erőfeszítéseket,

- önmagunkban változtatunk meg valamit: pl. tanulással igyekszünk megszerezni valamilyen hiányzó készséget, képességet.

\section{Az érzelemközpontú megküzdés}

Az érzelemközpontú megküzdést akkor választja az egyén, amikor nincs hatása az adott eseményre, pl. szeretett személy halála, munkahelyi elbocsátás. Ilyenkor az egyén a helyzetet nem tudja megváltoztatni.

Ezekben az esetekben a személy célja egyrészt, hogy megakadályozza, hogy a helyzet által keltett negatív érzések elhatalmasodjanak rajta. Másrészt, a személy ezekkel a stratégiákkal elkerüli a probléma megoldásával való foglalkozást.

Az érzelemközpontú megküzdési stratégiák többféleképpen csoportosíthatók. Néhányan viselkedéses és kognitív módszereket különítenek el (Moos, 1988). A viselkedéses technikák közé tartozik az a testmozgás, amit azért végez az egyén, hogy elterelje figyelmét a problémáról. Idetartozik még az alkohol- és drogfogyasztás, vagy az érzelmi támasz keresése a barátoknál. Kognitív stratégiát alkalmaz az a személy, aki időlegesen félreteszi a problémát (,nem gyötrődöm ezzel”), vagy a helyzet jelentését megváltoztatva, újraértékelve csökkenti a kellemetlen érzéseket („nem is fontos nekem ez a dolog”). Bizonyos viselkedéses és kognitív stratégiák nagyon adaptívak, vannak azonban károsak is (pl. túlzott alkoholfogyasztás).

Mások kérődző, elterelő és negatív elkerülő stratégiákat különböztetnek meg az érzelemközpontú megküzdésen belül. A kérődző stratégiák közé tartozik, amikor a személy visszavonul a világtól, hogy töprenghessen a negatív hatás 
következményein, és átadhassa magát gyötrő érzéseinek. Sokat beszél környezetének arról, hogy milyen rossz ez a helyzet, és mennyire kellemetlenül érzi magát, de nem tesz konkrétan semmit a változás érdekében. Ez a stratégia megnyújtja és elmélyíti a rossz hangulatot, és azok, akik ilyen stratégiát választanak, kevésbé hajlanak a probléma aktív megoldására.

Az elterelő stratégiák lényege, hogy az egyén valamilyen kellemes tevékenységbe menekül, pl. sportol, moziba jár, kirándul stb. Ezek alkalmazásával a személy kikapcsolódik (,feltöltődik”), ami segíti önmaga megerősödését, és azt, hogy helyzet fölötti kontrollját visszaszerezze. Ezek a stratégiák megrövidítik és gyengítik a lehangoltságot, és azok, akik ilyen stratégiát alkalmaznak, miután megszabadulnak rossz hangulatuktól, gyakrabban keresik a helyzet aktív megoldását.

A negatív elkerülő stratégiák alkalmazásával a személy potenciálisan veszélyes dolgokkal tereli el figyelmét a problémáról. Idetartozik például a túlzott alkoholfogyasztás, önveszélyes viselkedés (száguldozás motorral/autóval), vagy másokkal szembeni agresszió. Ezek a stratégiák szintén meghosszabbítják és mélyítik a rossz hangulatot, és alkalmazásuk természetesen tovább ront a helyzeten, hosszabb távon akár súlyosabb testi és lelki sérülést is eredményezhetnek.

Lazarus és Folkman (1986) kutatásai eredményeként a problémaközpontú és érzelemközpontú megküzdési formákon belül további nyolcféle stratégia különíthető el, melyek a következők:

- konfrontáció: ez a problémával való szembehelyezkedést, aktív megküzdést jelenti;

- eltávolodás: a helyzettől való érzelmi és mentális távolságtartást jelenti, hogy energiát gyüjthessen a további megküzdéshez;

- érzelmek és viselkedés szabályozása: ez az adott helyzet megoldását legjobban segítő érzelmi kifejezésmód és viselkedés megtalálását jelenti;

- társas támogatás keresése: a társas környezet részéről rendelkezésre álló erőforrások, támogatások keresését és kihasználását jelenti;

- a felelősség vállalása: az észlelt, tulajdonított kontroll vállalása kerül elötérbe ebben az esetben;

- problémamegoldás-tervezés: kifejezetten kognitív, racionális stratégia, azoknak a lehetőségeknek a kiértékelését jelenti, amelyek a helyzet megoldását elősegíthetik; elkerülés-menekülés: nem vállalja a konfrontációt, kilép a szituációból;

- pozitív jelentés keresése: a negatív jelentésü esemény kihívásként, bizonyos szempontból pozitívként való értékelése történik ekkor. 
Lazarus (1990) szerint ezek a stratégiák az egészséges, érett személyiség jellemzői. Patológiás konfliktusmegoldás esetén az érzelmek szabályozása zajlik, elsősorban az énvédelem, a szorongás csökkentése a cél, ez énvédő vagy elhárító mechanizmusokon keresztül zajlik.

\section{Megküzdési stratégiákkal kapcsolatos kutatási eredmények}

A coping stratégiákkal kapcsolatos kutatások jelentős része az életkornak és a nemnek a megküzdési módokkal kapcsolatos összefüggéseire keresték a választ. Amerikai kutatási eredmények szerint a fiatalabb serdülök inkább a szüleikben bíznak, amikor fontos döntést kell meghozniuk, és érzelmi támaszt várnak tölük, az idősebb serdülők inkább probléma megoldó stratégiát alkalmaznak (Hutchinson, Baldwin, Oh, 2006).

Néhány kutató szerint a nem nincs hatással arra, hogy milyen coping stratégiát alkalmaz a fiatal (pl. Hutchinson, Baldwin, Oh, 2006). Mások szerint azonban a lányok inkább kérnek szociális támogatást, mint a fiúk (Copeland, és Hess, 1995; Hess, és Copeland, 2001), és a fiúk inkább problémamegoldó, míg a lányok inkább érzelem fókuszú megküzdési stratégiát használnak (Li és mtsai, 2006). Ez utóbbi kutatás szerint az érzelemfókuszú stratégiát alkalmazók inkább hajlamosak a depresszióra, mint a problémaközpontú stratégiát preferálók, mert aki problémafókuszú megoldásokat alkalmaz, könnyebben tudja az erőforrásait mozgósítani.

A fiúk a stresszel való megküzdés során hajlamosabbak az agresszió és a harag kifejezésére, míg a lányok inkább internalizáló érzelemközpontú viselkedéseket mutatnak (Maschi és mtsai, 2008). Ismét mások azt találták, hogy a fiúk esetében a bünöző magatartás negatív kapcsolatban áll a problémamegoldó copinggal: minél jellemzőbb egy fiúra a bünöző viselkedés, annál kevésbé képes problémamegoldó stratégiát alkalmazni. A kényszeres problémákat mutató fiúk között pedig szignifikánsan többen alkalmaznak érzelemközpontú megküzdést (Compas és mtsai, 1988).

Oláh Attila (1995) nemzetközi kutatásainak eredményei szerint az általa vizsgált (magyar, indiai, olasz, svéd, jemeni) kultúrákban a serdülők alacsony és közepes szorongásszint esetén a megküzdés konstruktív útjait, míg magas szorongásszint esetén az elkerülést alkalmazták mint a feszültséggel való maladaptiv megküzdést. Herman-Stahl és Petersen (1996) kutatásai szintén a depresszió tünettanával együtt járó passzív és elkerülő coping magasabb, a közelítő coping alacsonyabb szintjét mutatták ki serdülőknél.

Margitics Ferenc (2005) föiskolások körében végzett kutatási eredményei szerint a depressziós tünetegyüttessel legszorosabb összefüggést az érzelemköz- 
pontú megküzdési módok mutatták, elsősorban az érzelmi indíttatású cselekvés és a visszahúzódás, valamint a kognitív átstrukturálás hiánya.

Billings és Moos (1984) kutatásaik során azt találták, hogy akik problémaközpontú megküzdést használtak stresszhelyzetekben, mind a stressz alatt, mind a stressz után kevésbé voltak depressziósak. Kínai orvostanhallgatók között végzett kutatás eredményei azt mutatják, hogy depresszív hangulatú és nem depreszszív hangulatú hallgatók egyenlő mértékben használtak olyan megküzdési módokat, mint a problémamegoldás és kognitív átstrukturálás. A depresszív hangulatú hallgatók esetében azonban ezen stratégiák hatékonyságát csökkentette a problémán való tünődés és passzivitás. Ezen kívül hajlamosak voltak a probléma elkerülésére és tagadására is (Chan, 1992).

Hazai felmérések szerint a kockázatos vagy passzív coping mechanizmus használata rontja a pszichoszociális egészséget serdülőkorban (Pikó és Keresztes, 2001). A problémaközpontú megküzdés jobb alkalmazkodó képességgel van kapcsolatban, míg az, aki emóciófókuszú stratégiákat alkalmaz, több problémával küzd (Li és mtsai, 2006).

A kötődési stílus és a nehéz élethelyzetben alkalmazott megküzdési mód öszszefüggésére irányuló amerikai kutatás a biztonságosan kötődő serdülők esetében magas kommunikációt és alacsony szintű elkerülésre irányuló megküzdést talált. A bizonytalan kötődésű serdülők inkább az elkerülésre irányuló problémamegoldó stratégiát választják, feltehetően azért, mert ők a társakban kevésbé bíznak, a támogatásra érdemtelennek érzik magukat (Howard és Medway, 2004).

\section{Vizsgálat a Debreceni Egyetem Egészségügyi Kar hallgatói körében}

Kutatásunkban arra keresünk választ, hogy a megváltozott társadalmi, gazdasági viszonyok, a fiatalok megváltozott lehetőségei között milyen fontos egészségmegőrző, protektív tényezőket azonosíthatunk a mentális egészség megvalósítása érdekében. Fő irányvonalunk az előzőekben vázolt coping stratégiák feltérképezése. Ezek a megküzdési jellegzetességek jól mérhetőek és jól megnyilvánulóak a viselkedésben. Célunk volt annak megismerése, hogy a megkérdezettek hogyan gondolkodnak saját megküzdési módjaikról. Valamint azt is szerettük volna feltérképezni, hogy viselkedési szinten, nehéz szakmai helyzetek kezelése során hogyan nyilvánulnak meg ezek a coping stratégiák. Található-e összefüggés a megküzdési móddal való önjellemzés és a viselkedéses megnyilvánulások között. Hipotéziseink a következők voltak: 
1. A megkérdezett hallgatók főképp racionális, problémafókuszú megküzdési móddal jellemezhetőek.

2. A problémafókuszú megküzdési mód viselkedési szinten a nehéz helyzetek kognitív megoldásában nyilvánul meg.

3. A megkérdezett hallgatók kevésbé jellemezhetőek emóciófókuszú megküzdési móddal, így az érzelmek kifejezése, empátia kevésbé nyilvánul meg a nehéz helyzetek megoldásában.

4. A megkérdezettek kevés eszközzel rendelkeznek a nehéz helyzetek megoldásában.

\section{Vizsgált személyek}

A vizsgálatban elsőéves, segítő szakmára készülő hallgatók vettek részt, diplomás ápolók, mentőtisztek, szülésznők, egészségügyi ügyvitelszervezők. Az alábbi diagram (1. számú ábra) mutatja a megkérdezettek nem és alapszak szerinti megoszlását.

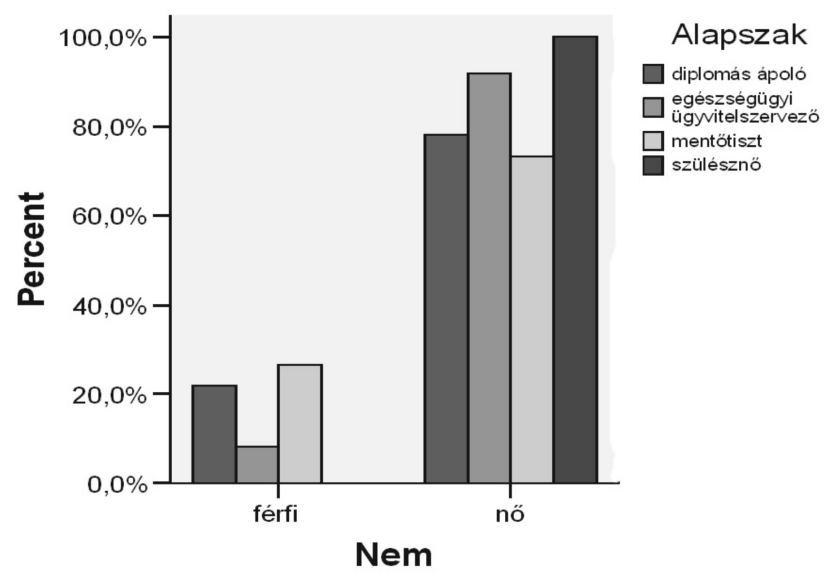

1. számú ábra.

A vizsgálati személyek nemek és szakok szerinti megoszlása. 


\section{Vizsgálati módszer}

A Megküzdési Módok Kérdőív eredeti változatát, Folkman és Lazarus dolgozta ki 1980-ban, ami 68 kérdésből állt. Kopp Mária és Skrabski Árpád vizsgálatai alapján, kialakították az eredeti kérdőív rövidítetett változatát, ami jelenleg 22 tételből áll, hogy minden faktor a legjellemzőbb tételeivel szerepel. A kérdőív a hét probléma megoldási faktorra kérdez rá. A problémaelemzés, a céltudatos cselekvésre, amik a problémamegoldó konfliktusmegoldásra irányul. Az érzelmi indíttatású cselekvésre, az alkalmazkodásra, a segítségkérésre, az érzelmi egyensúly keresésére, és a visszahúzódásra. Ezek a kérdéscsoportok pedig az érzelemi problémamegoldásokra irányulnak. A kérdésekre 0-tól 3-ig - a nem volt rá jellemzö, az alig volt rá jellemző, jellemző, és a nagyon jellemző válaszok lehetségesek.

Nehéz segítői helyzetek bemutatására egy olyan filmet választottunk, ami a segítői hivatásra készülők számára példaértékű szakmai hozzáállást mutat be. Patch Adams története, aki igazi orvos lett, és forradalmasította a gyógyítást az emberekhez való viszonyával, hozzáállásával. 1969-ben a nyugtalan egyetemista Patch önként jelentkezik pszichiátriai kezelésre. Az osztályon hamar kitünik segítőkészségével. Rájön, hogy sokan közülük félrekezeltek, elhagyottak. Patch értelmet talál társai felvidításában, az intézetből kikerülve komolyan veszi orvosi tanulmányait. Jó eredményei ellenére tanárai ellenzik furcsa gyógyítási szokásait. Szerintük Patch lejáratja szakmájukat viselkedésével. Hamar összetüzésbe kerül a felsőbb orvosi hatóságokkal is, de társai, a nővérek és leginkább a betegek védelmükbe veszik a mindig mosolyra kész doktort. A jókedvet, a személyességet, az emberséget jeleníti meg a gyógyításban, és rámutat arra, hogy az intézményi rendszer müködése hogyan hathat mindezek ellen.

A filmböl öt jelentet választottunk ki, melyet a következő instrukcióval dolgoztuk fel. „A következőkben a filmnézés kapcsán 5 jelenetre fogunk rákérdezni. A jelenet elején megállítjuk a filmet és arra kérjük, hogy írja le véleményét arról, hogy mit tenne ÖN a segítő szerepében az adott problémahelyzetben" Az öt jelenet a következő volt:

1. Pszichiátriai, téveszmékkel küzdő beteg szorongásának oldása, félelmeinek csökkentését célzó éjszaka játszódó jelenet.

2. Szorongó, cukorbeteg hölgy a kórház folyosóján egyedül fekszik, az orvosok, orvostanhallgatók mellette, de személytelenként kezelik a beteget.

3. Leukémiás gyermekek csendes kórterme, alvó, szorongó gyermekekkel való kapcsolat létesítése

4. Haldokló beteg kórházi ágya mellett, a beteg támogatása

5. Idős, nem evő hölgy, minden táplálékot visszautasít, hangulata deprimált. 


\section{Eredmények}

A jelenetek feldolgozása során a tartalomelemzés technikáját alkalmaztuk. Ez alapján 11 válaszkategóriát határoztunk meg, melyeket az alábbiakban ismertetünk.

A hibás gondolkodás megváltoztatása kategória arra a megoldásmódra irányul, amikor a beteg gondolkodását próbálja a segítő megváltoztatni. Például a pszichiátriai beteg esetében a téveszmékről próbálta meggyőzni, hogy „,azok csak a fejében léteznek". A hallgatóink ezt a megoldásmódot kevésbé preferálják, tisztában vannak azzal, hogy a beteg gondolkodásmódja adott, ennek befolyásolása nem vezethet eredményre.

A racionális problémamegoldás a válaszok azon részét képezik, amelyek a beteg értelmére, kognitív struktúrájára próbál hatni. Például a téveszmékkel küzdő beteg esteében „megmagyarázom, hogy a mókusok nem bántanak”. Vagy a haldokló beteg esetében „elmondom neki, hogy szép helyre kerül majd a túlvilágon". Ezt a megoldásmódot széles körben alkalmazzák a segítő hivatásra készülök. A problémák kognitív szintü megoldásmódját eszköznek használják fel a segítés során, mint ahogy majd a későbbiekben is ismertetjük. Azonban ez nem elégséges a kompetens szakmai viselkedéshez, ennek tudatosítása fontos feladata az oktatásnak.

A problémamegoldás cselekvéssel kategória aktivitást feltételez, a nehéz helyzeteket cselekvéssel oldom meg. Például a nem evő idős hölgy esetében „megfőzöm a kedvenc ételét, megetetem”. A hallgatók harmada nem visz aktivitást, cselekvést a megoldásmódokba. Az általuk végzett szakmák megfelelő müveléséhez ez a fajta viselkedés elengedhetetlen. Ennek megtanulása és a tanultak alkalmazása szintén az oktatásba beépítendő feladat.

Az okok feltérképezése kategória diagnosztikus célzatú válaszokat tartalmaz. Például az idős nem evő hölgy esetében „megkérdezem, miért nem eszik”. A diagnosztikus elemek kevésbé jelennek meg a hallgatók gondolkodásában. Az okok, azok a tényezők, amelyek a probléma kialakulásához vezettek, úgy tünik nem eszköz a megkérdezettek kezében. A gyógyító munka során az azonnali cselekvés, a tünetek, következmények enyhítése a feladat, így természetes módon az előzmények feltérképezése háttérbe szorul, de sok esetben befolyásolja a gyógyító folyamatot, ezért ismerete, alkalmazása szintén fontos.

Az empátia megnyilvánulási módjai is megtalálhatóak. Szinte valamennyi jelenetben használják a megkérdezettek. Ilyen válaszok tartoznak ide, mint „együtt érzek vele, megnyugtatom, átérzem a helyzetét". Nagyon fontos az optimális empátiás készség a segítő szakmában dolgozók esetében. Az első éves hallgatók megfelelő odafordulással, együttérzéssel jellemezhetőek. 
A segítői attitüdök a következő válaszokat fedik le. „kedves vagyok, segítek neki, meghallgatom, mesét olvasok, türelmes vagyok, stb.” ebben a kategóriában is találhatunk számos megoldást. Ezek is olyan intrapszichés mechanizmusok, amelyek alkalmazása elengedhetetlen a gyógyítói munka során. Megkérdezettjeink gyakran alkalmazzák ezeket is.

A játékosság kategória kevésbé volt népszerü. A leukémiás gyermekek esetében célzottan jelent meg, valamint a pszichiátriai beteg estében.

$\mathrm{Az}$ énbevonódás kevésbé választott kategória. Saját élmények átadása, saját emlékek megosztása a beteggel tartozik ide. „Elmondom, hogy én mit tettem ebben az esetben." A segítő saját mentális egészségének megörzése és hatékony munkavégzése érdekében kerülje ezt az alkalmazási módot. Hallgatóink is tudják ezt, kis számban választották.

A kreativitás a szokatlan, újszerủ megoldásmódokat igénylő válaszokat írta le. Hallgatóink találékonysága alacsony színvonalú, csupán néhányan kerültek ebbe a kategóriába. Például a téveszmékkel küzdő beteget próbálja az egyik válaszadó aprólékosan, részletesen hozzászoktatni a félelme tárgyához, a behaviorista deszenzitizációs technika pontosságával.

Inadekvát, a helyzetbe nem illő megoldást adó válaszok száma is kevés volt. A leukémiás gyermekek esetében előfordult válasz: „sírva kirohannék”.

Külső segítség igénybevétele kategória szintén kevésbé alkalmazott viselkedési megnyilvánulási mód. Érvényesül itt a gyógyító munkáról való individualista felfogásmód, az önálló cselekvésre való igény, és az az elképzelés, hogy a munka során az egyéni felelősségvállalás érvényesül. Hallgatóink nehezen kérnek segítséget, és nehezen ismerik fel azokat a helyzeteket, ahol már nem kompetensek. Ezeket a határokat, készségeket is fejleszteni kell.

Az előbbiekben bemutatott kategóriákra kapott válaszok előfordulási gyakoriságát (0-szor, 1-szer, ....5-ször választották, tehát egy jelenetre, vagy kettöre, vagy....mind az 5 jelenetben előfordult) az 2. számú táblázat mutatja be: láthatjuk, hogy a zömében kognitív megoldások mellett megjelenik a segíteni akarás attitüdje, valamint az empátiás készség is nagy változatosságot mutat, ami jelzi a hallgatók szakma iránti érzékenységét. Azonban a kreativitás és külső segítség igénybevételének hiánya a szakmai tudatosság fejlesztésének szükségszerüségére hívja fel a figyelmet. 


\begin{tabular}{|l|c|c|c|c|c|c|}
\hline & 0 & 1 & 2 & 3 & 4 & 5 \\
\hline $\begin{array}{l}\text { Hibás gondolkodás meg- } \\
\text { változtatása }\end{array}$ & $\mathbf{6 9 , 1 \%}$ & $27,2 \%$ & $3,7 \%$ & & & \\
\hline $\begin{array}{l}\text { Racionális problémameg- } \\
\text { oldás }\end{array}$ & $13,0 \%$ & $\mathbf{3 2 , 5 \%}$ & $\mathbf{2 6 , 4 \%}$ & $18,3 \%$ & $9,3 \%$ & $0,4 \%$ \\
\hline $\begin{array}{l}\text { Problémamegoldás cse- } \\
\text { lekvéssel }\end{array}$ & $\mathbf{3 1 , 7 \%}$ & $\mathbf{3 9 , 8 \%}$ & $23,6 \%$ & $4,9 \%$ & & \\
\hline Okok feltérképezése & $\mathbf{7 8 , 0 \%}$ & $19,5 \%$ & $2,4 \%$ & & & \\
\hline Empátia & $7,7 \%$ & $16,7 \%$ & $\mathbf{3 2 , 9 \%}$ & $\mathbf{3 0 , 9 \%}$ & $11,8 \%$ & \\
\hline Segítői attitüd & $5,3 \%$ & $10,2 \%$ & $\mathbf{2 3 , 6 \%}$ & $\mathbf{2 9 , 7 \%}$ & $\mathbf{2 3 , 6 \%}$ & $7,7 \%$ \\
\hline Játékosság & $\mathbf{6 0 , 2 \%}$ & $33,7 \%$ & $6,1 \%$ & & & \\
\hline Énbevonódás & $\mathbf{9 0 , 7 \%}$ & $8,5 \%$ & $0,8 \%$ & & & \\
\hline Kreativitás & $\mathbf{8 1 , 7 \%}$ & $17,1 \%$ & $0,8 \%$ & $0,4 \%$ & & \\
\hline Inadekvát válaszok & $\mathbf{8 2 , 5 \%}$ & $15,9 \%$ & $1,6 \%$ & & & \\
\hline $\begin{array}{l}\text { Külsó segítség igénybevé- } \\
\text { tele }\end{array}$ & $\mathbf{8 6 , 6 \%}$ & $13,0 \%$ & $0,4 \%$ & & & \\
\hline
\end{tabular}

2. számú táblázat.

A filmjelenetekkel kapcsolatos tartalomelemzés eredményei.

A 3. számú táblázatban láthatjuk, hogy a megküzdési módokkal hogyan jellemzik önmagukat a segítő hivatásra készülö hallgatók.

\begin{tabular}{|c|c|}
\hline MEGKÜZDÉSI MÓD & Gyakoriság \\
\hline Problémaelemzés & $83 \%$ \\
\hline Segítségkérés & $77 \%$ \\
\hline Céltudatos cselekvés & $76 \%$ \\
\hline Érzelmi egyensúly keresése & $69 \%$ \\
\hline Alkalmazkodás & $68 \%$ \\
\hline Visszahúzódás & $50 \%$ \\
\hline Érzelmi indíttatású cselekvés & $25 \%$ \\
\hline
\end{tabular}

3. számú táblázat.

A megküzdési módok gyakorisága.

Láthatjuk, hogy a problémafókuszú megküzdési módok (problémaelemzés, céltudatos cselekvés) túlsúlya érvényesül. Az emóciófókuszú megküzdési módok közül az érzelmi egyensúly keresése, az alkalmazkodás és a segítségkérés coping stratégiákkal szintén nagyobb arányban jellemzik önmagukat. A visszahúzódás megküzdési módra adott önjellemzések kevésbé dominánsak. Az érzelmi indíttatású cselekvés a megkérdezettek közel harmadára jellemző. 
A megküzdési módok ilyen megoszlása több kérdést is felvet. Egyrészt a segítői hivatás a problémaelemzést kívánja meg. Így szerencsések a kapott önjellemzések. Másrészt a kapott eredményekben tükröződnek a modern társadalom elvárásai, napjaink teljesítményorientált értékei. Az individualizmus, az aktivitás preferenciája, ami a segítő szakma hatékonyságát csökkenti, színvonalát mérsékelheti. Harmadrészt a segítői hivatás igényli az érzelmek megfelelő kezelését is, ami a kapott eredmények alapján nehézséget okoz hallgatóinknak.

A 4. táblázat az önjellemzésen alapuló megküzdési stratégiák és a filmjelenetekkel kapcsolatosan felmerülő viselkedések közötti kapcsolatokat Pearson korrelációk értékével szemlélteti. Bemutatja azokat az összefüggéseket, melyek a megküzdési módok önjellemzése és a nehéz helyzetekre adott reakciókból következtethetőek.

\begin{tabular}{|c|c|c|c|c|c|}
\hline \multirow[t]{2}{*}{$\begin{array}{l}\text { Megküzdési } \\
\text { módok }\end{array}$} & \multicolumn{5}{|c|}{$\begin{array}{l}\text { Önmagamról feltételezett válaszreakció, a nehéz helyzetek } \\
\text { kezelése során, a filmjelenetek elemzésekor }\end{array}$} \\
\hline & $\begin{array}{l}\text { Racioná- } \\
\text { lis } \\
\text { probléma } \\
\text { meg- } \\
\text { oldás }\end{array}$ & $\begin{array}{l}\text { Probléma } \\
\text { megol- } \\
\text { dás cse- } \\
\text { lekvéssel }\end{array}$ & Empátia & $\begin{array}{l}\text { Segítői } \\
\text { attitüd }\end{array}$ & $\begin{array}{c}\text { Énbevo- } \\
\text { nódás }\end{array}$ \\
\hline $\begin{array}{l}\text { Problémaelem- } \\
\text { zés }\end{array}$ & $\begin{array}{l}0,22 \\
(0,000)\end{array}$ & & $\begin{array}{l}0,15) \\
(0,016)\end{array}$ & $\begin{array}{l}0,17) \\
(0,007)\end{array}$ & \\
\hline $\begin{array}{l}\text { Céltudatos cse- } \\
\text { lekvés }\end{array}$ & $\begin{array}{l}0,156 \\
(0,014)\end{array}$ & & & $\begin{array}{l}0,207) \\
(0,001)\end{array}$ & \\
\hline $\begin{array}{l}\text { Érzelmi indítta- } \\
\text { tású cselekvés }\end{array}$ & & & & & \\
\hline Alkalmazkodás & & & & & \\
\hline Segítségkérés & $\begin{array}{l}0,150 \\
(0,019)\end{array}$ & & $\begin{array}{l}0,199 \\
(0,002)\end{array}$ & & \\
\hline $\begin{array}{l}\text { Érzelmi egyen- } \\
\text { súly keresése }\end{array}$ & & $\begin{array}{l}0,157 \\
(0,013)\end{array}$ & & & \\
\hline Visszahúzódás & & & & & $\begin{array}{l}0,146 \\
(0,022)\end{array}$ \\
\hline
\end{tabular}

4. táblázat. Az önjellemzésen alapuló megküzdési stratégiák és a filmjelenetekkel kapcsolatosan felmerülő viselkedések közötti kapcsolatok. Zárójelben a Pearson-féle korrelációs együttható értékei szerepelnek. 
Mint láthatjuk, néhány szignifikáns összefüggést találhatunk a megküzdési módok és a filmjelenetekkel kapcsolatosan feltételezett viselkedési reakciók között.

Az egyik domináns tendencia, miszerint a hallgatók a filmjelenetek kapcsán az önmagukról feltételezett viselkedési reakció során a problémafókuszú megoldásmódokat preferálják, mint az önjellemzés alapján is. Ezeket megfelelő hatékonysággal alkalmazzák racionális, kognitív szinten, azonban az aktivitás, ami a segítő hivatás elengedhetetlen feltétele, a hatékony cselekvés eszközei hiányoznak készségeik közül. Ezzel párhuzamosan megjelenik az empátia, a segítői attitüd, szintén, mint számukra kognitív megoldási mód a nehéz helyzetek kezelésére. Problémát jelent számukra elkülöníteni a segítői szándék jelenlétét, a tényleges hatékony segítéstől. Természetesen életkoruk, tapasztalataik, tanulmányi előrehaladásuk alapján nem kívánjuk ennek teljes ismeretét, de fontos szempont az oktatás és a mindennapi munka során, hogy a segíteni akarás, amellyel szerencsés módon tudatos szinten rendelkeznek a hallgatóink, nem egyenlő a segítéssel. Van szándék, és motiváció, de ehhez megfelelö, tudatosan használt eszközökre is szükség van.

A másik tendencia, hogy az emóciófókuszú megküzdési módok és a nehéz helyzetekre adott válaszmódok között kevés korrelációt találhatunk, szintén jó prognózis lehet a szakmai identitás fejlesztéséhez, hiszen az érzelmi kontroll, az érzelmek tudatos megélése hallgatóink esetében jelen lehet a nehéz helyzetek kezelésében. Szakmai helyzetben inkább racionális énjüket veszik elő, de figyelnünk kell arra, hogy azokban az esetekben is, amikor emocionális, segítői attitüdre lenne szükség.

Mint azt a 4. számú táblázatban láthatjuk, a korrelációk alacsonyak, mert a kapcsolat nem lineáris a vizsgált változók között. E helyett inkább küszöb jellegü, tehát ha az egyik változó értéke elér egy bizonyos szintet, akkor a másik változó átlaga is magasabb lesz. A következő ábrák (5-9. ábra) tanulmányozása alapján árnyaltabb képet kaphatunk a kapcsolatokról. A függőleges tengely a megküzdési módot ábrázolja, míg a vízszintes tengelyen a nehéz helyzetekre adott válaszok előfordulási gyakoriságát szemléltetjük. 


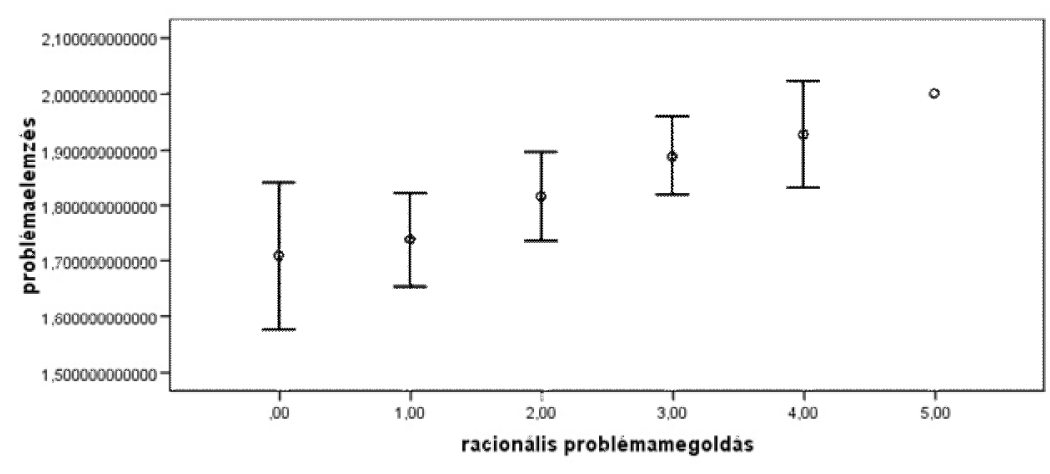

5. ábra.

A problémaelemzés, mint megküzdési mód és a racionális problémamegoldás, mint lehetséges válaszlehetőség összefüggése a csoportátlagok és a hozzájuk tartozó konfidencia intervallumok alapján

A 5. ábrán, a problémaelemzés megküzdési móddal önjellemzett hallgatók esetében a vizsgált összefüggés azt mutatja, hogy a racionális problémaelemzés, mint válaszlehetőség alkalmazása során a problémaelemző megküzdési mód akkor érvényesül igazán, ha több, változatos válaszlehetőséget képes adni a hallgató.

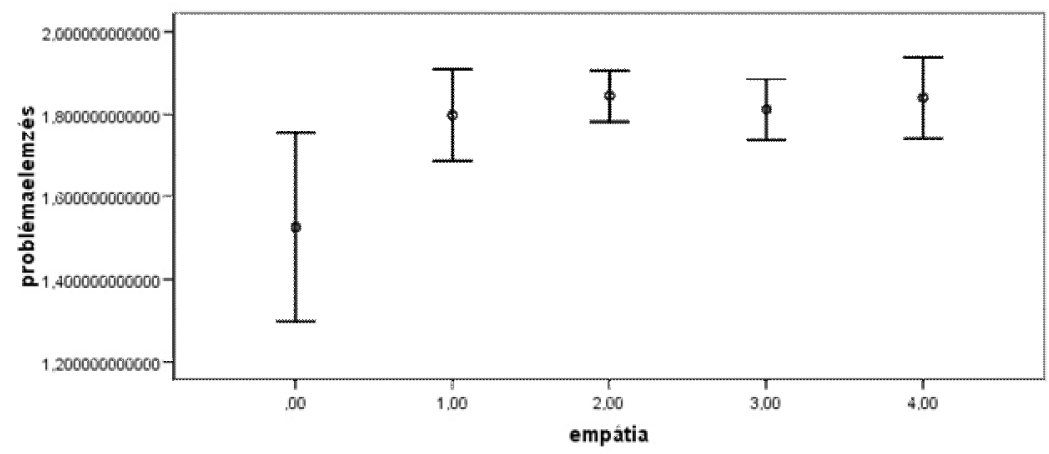

6 .ábra.

A problémaelemzés, mint megküzdési mód és az empátia, mint lehetséges válaszlehetőség összefüggése a csoportátlagok és a hozzájuk tartozó konfidencia intervallumok alapján. 


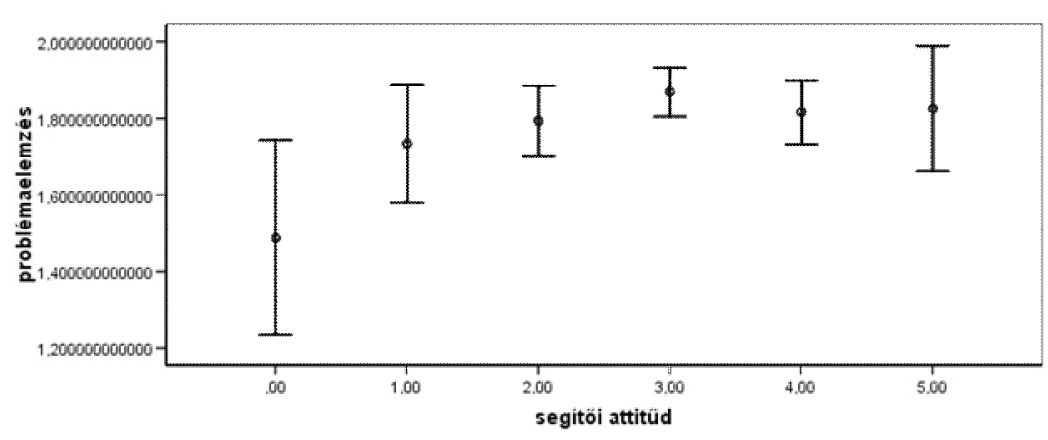

7 .ábra.

A problémaelemzés, mint megküzdési mód és a segítői attitüd, mint lehetséges válaszlehetőség összefüggése a csoportátlagok és a hozzájuk tartozó konfidencia intervallumok alapján.

A segítői attitüdök, az empátia esetében az igaz, hogy a vizsgált szakmai helyzetekben tanúsított legalább egy ilyen megnyilvánulás eredményesebb problémamegoldáshoz vezet, de a több ilyen megnyilvánulás nem jelent hatékonyabb problémaelemző coping stratégiát (6-7.ábra).

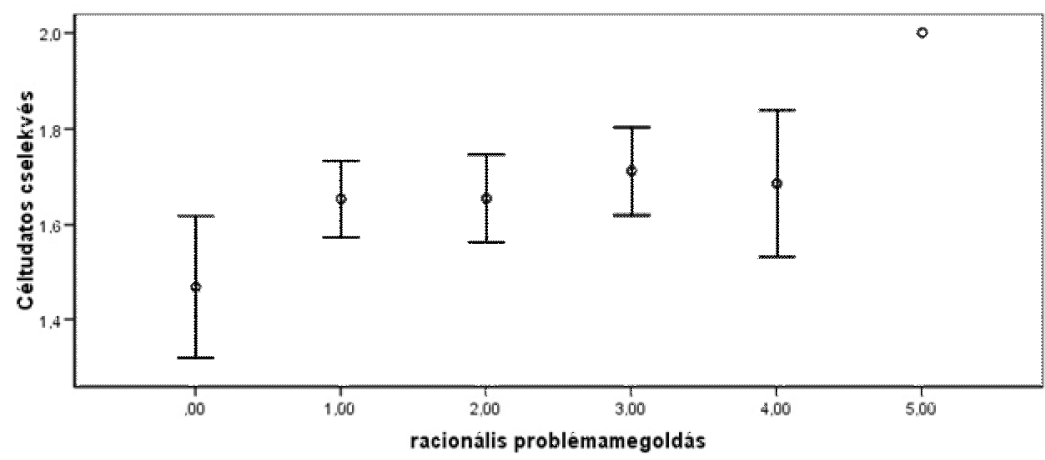

8. ábra.

A céltudatos cselekvés, mint megküzdési mód és a racionális problémamegoldás, mint lehetséges válaszlehetőség összefüggése a csoportátlagok és a hozzájuk tartozó konfidencia intervallumok alapján. 


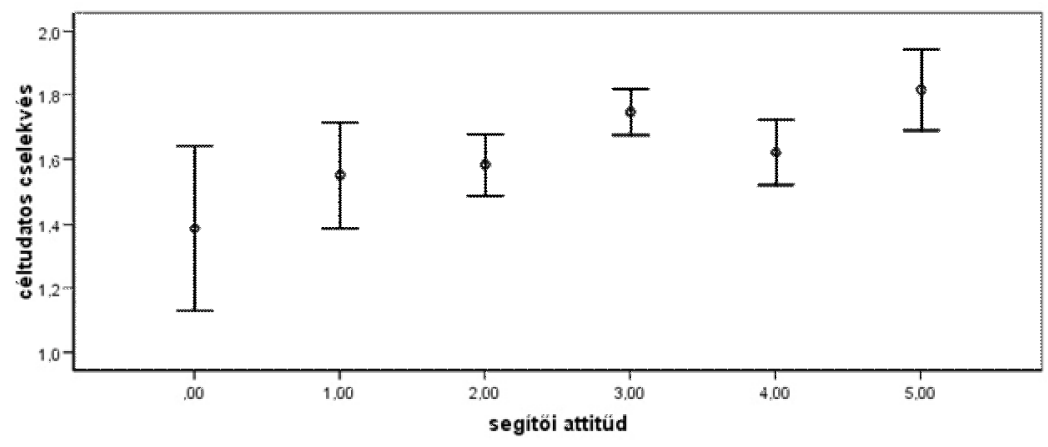

9. ábra.

A céltudatos cselekvés, mint megküzdési mód és a segítői attitűd, mint lehetséges válaszlehetőség összefüggése a csoportátlagok és a hozzájuk tartozó konfidencia intervallumok alapján.

A céltudatos cselekvés, mint megküzdési mód akkor jelenik meg hatékonyan, ha a hallgató (legalább egyszer) megmutatta, hogy a szakmai helyzeteket képes kognitív síkon megoldani, illetve kompetens a segítöi attitüdök alkalmazásában (8-9. ábra).

Mint láthatjuk, (5-9 ábrákon) a problémaelemzés, és céltudatos cselekvés, mint problémafókuszú megküzdéssel jellemzettek nagyobb mértékben alkalmazzák a racionális problémamegoldás kategóriát, valamint ők azok, akik hatékonyan használják az empátia és segítői attitüd eszközöket nehéz helyzetek kezelésekor. A hallgatók nagyobb része azonban nem rendelkezik azzal a képességgel, hogy különböző helyzetekben differenciáltan tudjon viselkedni (lásd. 2. sz. táblázat), így a megoldásmódjaikban a problémafókuszú megküzdési módok dominálnak. Így a beteggel való kapcsolatot a kognitív mechanizmusok hatják át, a segítést is ebből a megközelítésből értelmezik.

Szintén ezt támasztja alá, hogy az érzelmi fókuszú megküzdési módok közül, az érzelmi egyensúly keresése coping stratégiát azok vallják magukra nézve jellemzőbbnek, akiknél az aktivitás, cselekvés választása a leggyakoribb - ötből három alkalommal. Ez arra utal, hogy érzelmi stabilitást a cselekvés, aktivitás útján érhetik el (10. ábra). 


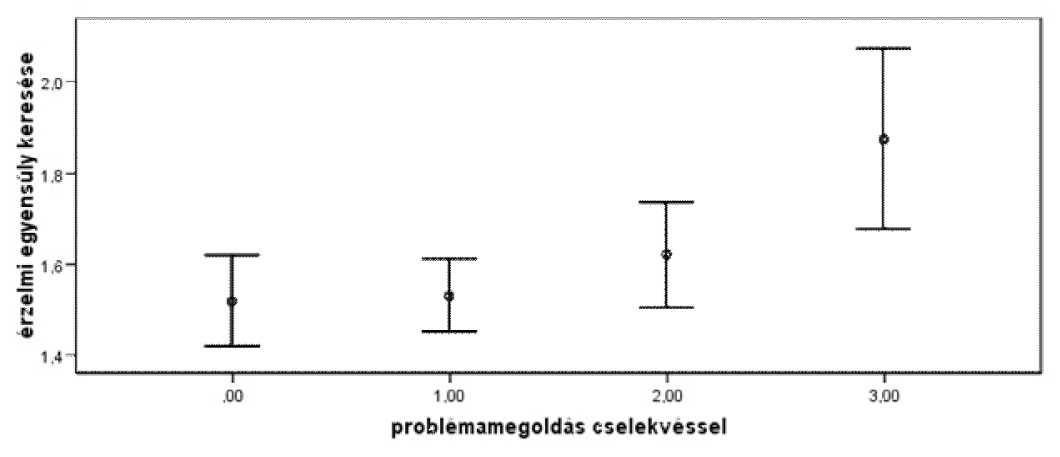

10. ábra.

Az érzelmi egyensúly keresése, mint megküzdési mód és a problémamegoldás cselekvéssel, mint lehetséges válaszlehetőség összefüggése a csoportátlagok és a hozzájuk tartozó konfidencia intervallumok alapján.

A segítségkérés érzelmi fókuszú megküzdési móddal önmagukat jellemzők esetében, mint ahogyan az alábbi ábrákon (11., 12. ábra) láthatjuk, érvényesül a racionális problémamegoldás, és az empátia eszközeinek alkalmazása.

Úgy tünik, a racionális problémamegoldás és az empátia megnyilvánulásai növelik a segítségkérés coping stratégia alkalmazásának esélyét, e megnyilvánulások közepes szintjéig (maximum 2). Ahhoz, hogy a segítségkérés tudatosan alkalmazott megküzdési mód legyen a szakmai munka során feltehetően szükséges a válaszra váró helyzetek kognitív differenciálása és az empátiás készség alkalmazása.

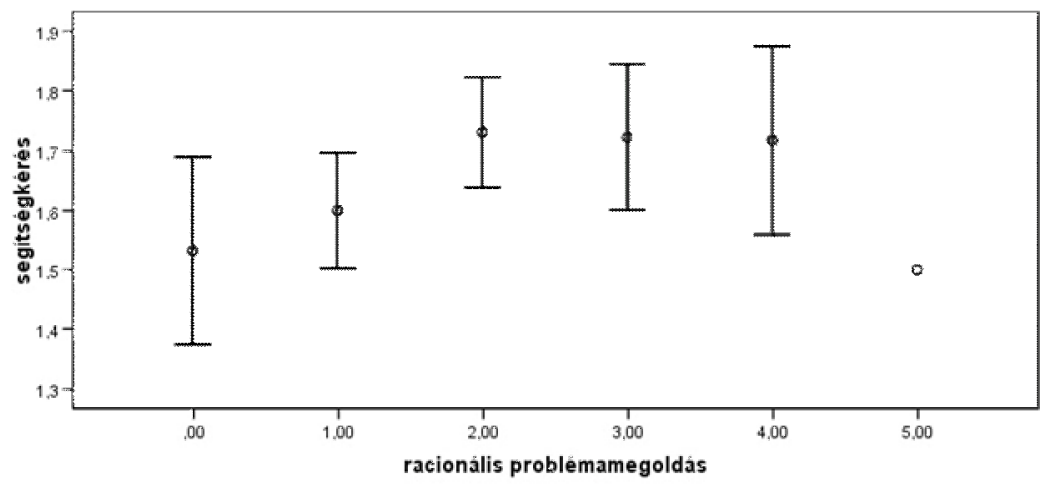

11. ábra.

A segítségkérés, mint megküzdési mód és a racionális problémamegoldás, mint lehetséges válaszlehetőség összefüggése a csoportátlagok és a hozzájuk tartozó konfidencia intervallumok alapján. 


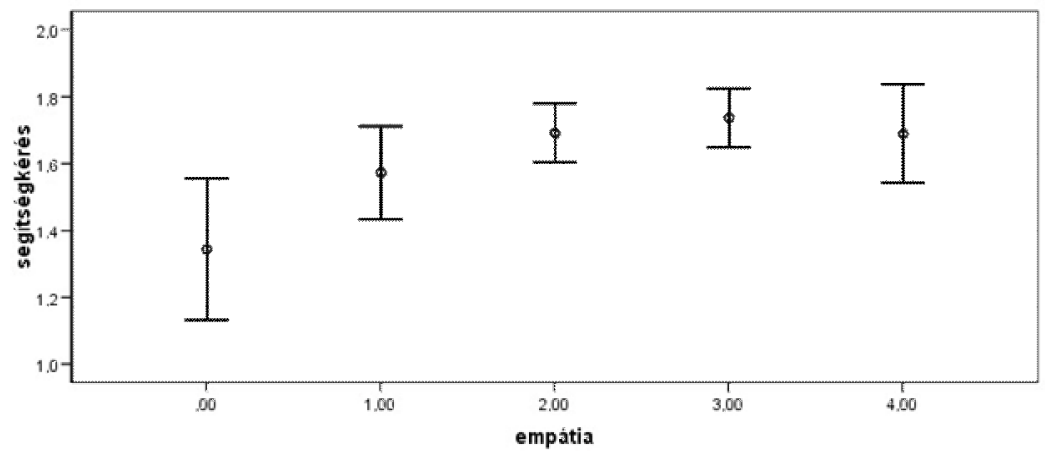

12. ábra.

A segítségkérés, mint megküzdési mód és az empátia, mint lehetséges válaszlehetőség összefüggése a csoportátlagok és a hozzájuk tartozó konfidencia intervallumok alapján.

\section{Összefoglalás}

Az első hipotézisben feltételeztük, hogy problémafókuszú megküzdési módokkal jellemzik önmagukat hallgatóink, ami igazolódott. Önmagukat a szakma és a társadalmi igények, az iskolai teljesítménymotiváció eredményeképpen problémamegoldónak jellemzik Az érzelmi fókuszú megküzdési módok közül a segítségkérés jelenik meg nagyobb arányban, ami jelzi a motiváltságot, igényt, a belevonódást, a segítő szakma iránt.

Második feltételezésünk, miszerint a problémafókuszú megküzdési mód viselkedési szinten a nehéz helyzetek kognitív megoldásában nyilvánul meg, részben igazolódott. A megkérdezettek a nehéz helyzetek kezelésében kognitív szintü megoldásokat preferálnak, azonban kevés aktivitást visznek bele válaszaikba, és kevésbé kreatívak. Azonban a racionális gondolkodást igénylő válaszok alacsony gyakoriságot mutatnak, szemben, az érzelmi töltetű empátia és segítői attitüd válaszlehetőségekkel. Ez utóbbiak nagy százalékban, a jelenetek között szélesebb eloszlásban jelennek meg a válaszadók között. A hallgatók értik, érzik a problémahelyzetek súlyát, de kevés tényleges eszközzel rendelkeznek ezek megoldására. Inkább az empátia, a segítői attitüd megoldásmódok ösztönös preferálásával találkozhatunk. Míg a segítségkérés, mint copingstratégiával nagyobb mértékben jellemzik önmagukat, addig a segítségkérés, mint lehetséges megoldási mód a beteggel való kapcsolat során kevésbé jelenik meg. A segítői szakmai hivatás szempontjából lényeges problémafókuszú coping stratégiák azokban az esetekben lehetnek hatékonyak, amikor a hallgató képes a helyzetek 
között differenciálni, több válaszlehetőséget alkalmazni és képes a segítői attitüdök és az empátia tudatos alkalmazására. Ha ez nincs jelen, akkor a mindennapokban használt racionális megküzdési mód ösztönösen érvényesülhet a segítői viselkedés mögött. A hallgató érti, érzi a segítő attitűd fontosságát, képes az empátiára, de ezt kevésbé tudatosan irányítva teszi.

Harmadik hipotézisünkben feltételeztük, hogy a megkérdezett hallgatók kevésbé jellemezhetőek emóciófókuszú megküzdési móddal, így az érzelmek kifejezése, empátia kevésbé nyilvánul meg a nehéz helyzetek megoldásában. A kapott eredmények alapján ez részben igazolódott. Az emóció fókuszú coping stratégiák kevesebb arányban fordultak elő hallgatóink önjellemzésében, viszont a nehéz helyzetek kezelése során domináns megoldásmódok voltak a segítői magatartások, és az empátia. Azonban ezeknek a szakmai helyzetekben való kompetens alkalmazása problémát jelent hallgatóink számára. Elméleti ismeretek jelennek meg, tudják, motiváltak a hallgatók a segítésre, de ezeket az ismereteket a készségek, képességek fejlesztésével, a tapasztalatok szerzésével kell formálni.

A negyedik feltételezésünk, miszerint kevés eszközzel rendelkeznek a beteggel való problémamegoldás terén, beigazolódott. Alacsony válaszgyakorisággal, sémaszerü megoldásmódokkal, kevés kreativitással jellemezhetőek válaszaik. Az empátia, segítői attitüd jelenléte mellett ezek szakszerű alkalmazásának hiányát tapasztalhatjuk. A segítői eszközök elsajátítása fontos, komoly feladat, hiszen e nélkül munkájuk és saját mentális egészségük megóvásának eredményessége kérdőjelezhető meg. Fontos megállapítanunk, hogy kevés inadekvát megoldásmód jelenik meg válaszaikban, igaz kevésbé kreatívak, de motiváltak, és szeretnék a segítést megfelelő hatékonysággal, kompetenciával végezni.

Nekünk oktatóknak ezek az eredmények figyelemreméltó üzeneteket közvetítenek. Egyrészt a racionalitás túlsúlya, az érzelmekkel való nehézkes bánásmód megjelenése felhívja a figyelmet arra, hogy az emóciók közvetítésével, értelmezésével foglalkozni kell. Másrészt eszközöket kell adni számukra, hogy valóban segítőként, a beteg és önmaguk javára tudjanak részt venni a gyógyító munkában. Harmadrészt a motiváltságukat, igényüket az empátiás megnyilvánulásokra, a segítői magatartásra tiszteletben kell tartanunk és helyes útra kell terelnünk.

Az ember -a segítő pedig különösen- ismerje a saját határait és azt igyekezzen betartani, és betartatni saját mentálhigiénéje érdekében. Mint ahogy erről szól Gautama Szidhárta története, aki csak akkor talált rá az arany középútra, miután tanúja volt egy zenemüvész és tanítványa beszélgetésének: „Ha túlfeszíted a húrt, elpattan. Ha laza nem szól. Közepesen feszesnek kell lennie.” Ezt az arany középutat, egyensúlyt kell megtalálnia és alkalmaznia annak, aki segítöként, terapeutaként mást kíván erre rávezetni - nem bedőlve a társadalom teljesítménykényszerének, sem a saját elvárásainak. 


\section{Felhasznált irodalom}

1. Arnett, J., J. (2007): Emerging Adulthood: What Is It, and What Is It Good For? Child Development Perspectives, Volume 1, Issue 2, pages 68-73, December 2007.

2. Atkinson, R. L., Atkinson, R. C., Smith, E. E., és Bem, D. J., (1997) Stressz. In: Atkinson, R. L., Atkinson, R. C., Smith, E. E., and Bem, D. J., Pszichológia. Osiris Kiadó, Budapest. 422-449.

3. Bagdy E.(1996): Hivatás és személyiség In.:Bagdy Emőke (szerk) A pedagógus

4. Billings, A. G., and Moos, R. H., (1984) Coping, stress and social resources among adults with unipolar depression. Journal of Personality and Social Psychology. 46. 887-891.

5. Cartwright, D., (1979): Contemporary Social Psychology in Historical Perspective, Social Psychology Quarterly, 1, 82-93.

6. Chan, D. W., (1992) Coping with depressed mood among Chinese medical students in Hong Kong. Journal of Affective Disorders, 24. 2. sz. 109-116.

7. Compas, B. E., Malcarne, V. L., Fondacoro, K. M., (1988) Coping With Stressful Events in Older Children and Young Adolescents. Journal of Consulting and Clinical Psychology, 56(3), 405-411.

8. Copeland, E., and Hess, R., (1995) Differences in young adolescents' coping strategies based on gender and ethnicity. Journal of Early Adolescence, 15(2), 203-219.

9. Csabai Márta - Barta Krisztina (2000): Az orvosi identitás alakulása: orvostanhallgatók nézete az orvosi pályáról, az orvosszerepről. Lege Artis Medicinae. 10, 638-644

10. Herman-Stahl, M. A. and Petersen, A. C., (1996) The protective role of coping and social resources for depressive symtomps among young adolescents. Journal of Youth and Adolescence, 25. 733-753.

11. Hutchinson, S. L., Baldwin, C. K., Oh, S., (2006) Adolescent Coping: Exploring Adolescents' Leisure-Based Responses to Stress. Leisure Sciences, 28, 115-131.

12. Hess, S., and Copeland, E., (2001) Students' stress, coping strategies, and school completion: A longitudinal perspective. School Psychology Quarterly, 16(4), 389-405.

13. Howard, M. S., Medway, F. J., (2004) Adolescents' Attachment and Coping With Stress. Psychology in the Schools, 41(3), 391-402.

14. Kopp Mária-Kovács Mónika Erika (2006): A magyar népesség életminősége az ezredfordulón Semmelweis Kiadó, Budapest 
15. Lazarus, R. S., (1990) Stress, coping and ilness. In: Friedman H. S. (szerk.): Personality and disease. Wiley, New York. 84-86.

16. Lazarus, R. S., (1991a) Cognition and motivation in emotion. American Psychologist, 46, 352-367.

17. Lazarus, R. S., (1991b) Emotion and Adaptation. New York: Oxford University Press.

18. Lazarus , R. S., and Folkman, S., (1984) Stress, Appraisal, and Coping. New York: Springer.

19. Lazarus, R. S., and Folkman, S., (1986) Coping and adaptation. In: Gentry W. D. (szerk.): The handbook of behavioral medicine. Guilford, New York. 235-312.

20. Lazarus, R. S., and Launier, R., (1978) Stress-related transactions between person and environment. In: Pervi, L. A., and Lewis, M. (eds.) Internal and external determinants of behavior. Plenum Press, New York.

21. Li, C. E., DiGiuseppe, R., Froh, J., (2006) The Roles of Sex, Gender, and Coping in Adolescent Depression. Adolescence, 41(163), 409-415.

22. Lisznyai Sándor (2010): Készülődő felnőttség. Kutatás a fiatalok mentálhigiénés állapota témakörében In: Életszakaszok határán Közösségi és egyéni tanulási feladatok szerk: Puskás-Vajda Zs. - Lisznyai S. FETA Könyvek 5. Budapest

23. Magyari Judit (2009): A családi narratívák és a jövőtől való szorongás öszszefüggései pályakezdő fiataloknál In: Egy igazolt praxis felé Újabb eredmények a pszichológia és a felsőoktatási tanácsadás hazai kutatásaiból szer: Puskás-Vajda Zs. - Lisznyai S. FETA Könyvek 4. Budapest

24. Margitics, F., (2005) A depresszív élményfeldolgozás háttértényezői főiskolai hallgatóknál. Mentálhigiéné és Pszichoszomatika, 6. 3. sz. 197-230.

25. Margitics Ferenc (2006): A szubklinikus depressziós tünetegyüttes háttértényezőinek vizsgálata föiskolai hallgatóknál Doktori értekezés, Debreceni Egyetem

26. Maschi, T., Morgen, K., Bradley, C., Hatcher, S. S., (2008) Exploring Gender Differences on Internalizing and Externalizing Behavior Among Maltreated Youth: Implications for Social Work Action. Child Adolescent Social Work Journal, 25, 531-547.

27. Mitchell, B. A. (2007) The Boomerang Age: Transitions to Adulthood in Families. Transaction Publishers, U.S.A. Murdock, N. L., \& Gore

28. Molnár Edit (2002): Ápolók egészségi állapota. Nővér, 15. 4. 4-10

29. Molnár Péter - Csabai Márta (2009): Orvosi pszichológia és klinikai egészségpszichológia, Medicina Könyvkiadó

30. Moos, R. H., (1988) Coping Responses Inventory Manual. Stanford University, Palo Alto. 
31. Oláh, A., (1995) Coping strategies among adolescents: A cross cultural study. Journal of Adolescence, 18. 4. sz. 491-512.

32. Pikó, B., Keresztes, N., (2001) Serdülők egészségmagatartása két szociális megküzdési (coping) mechanizmus tükrében. Magyar Pszichológiai Szemle, 62(2), 203-214.

33. Pikó Bettina (2001): A nővéri munka magatartástudományi vizsgálata: pszichoszomatikus tünetek - munkahelyi stressz - társas támogatás. Lege Artis Medicinae, 11. 4. 318-325.

34. Pikó Bettina, Piczil Márta (2006): A pszichoszociális munkakörnyezeti jellemzők összefüggése az elégedettséggel nővérek körében. Mentálhigiéné és Pszichoszomatika, 7. 4. 301-310.

35. Posgai Beáta - Oroszné Pál Zsuzsanna (2011): Kiégés és kontrollfunkciók a mentőtiszteknél TDK pályamunka

36. V. Komlósi, A., (2000) A személyiség értelmezései. In: Oláh, A., és Bugán, A., (szerk.) Fejezetek a pszichológia alapterületeiből. ELTE Eötvös kiadó, Budapest. 189-275.

Oroszné Pál Zsuzsanna: pszichológus, fôiskolai tanársegéd

Debreceni Egyetem Egészségügyi Kar, 4400 Nyíregyháza, Sóstói u. 2-4.

Sárváry Andrea: pszichológus, föiskolai docens

Debreceni Egyetem Egészségügyi Kar, 4400 Nyíregyháza, Sóstói u. 2-4. 


\section{UNIVERSITY \\ of DEBRECEN \\ FACULTY OF \\ HEALTH}

NYÍREGYHÁZA

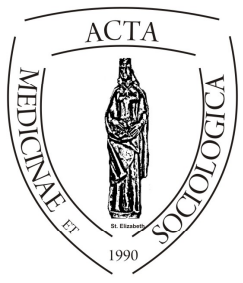

ACTA

MedSoc

VOLUME 5.

2014

\title{
A mellrák pszichoszociális vonatkozásainak vizsgálata $^{1}$
}

\author{
Suta Erika*, Sárváry Andrea** \\ *Rákosok Román Egyesülete - Kolozsvár \\ **DE Egészségügyi Kar, Pszichológiai Tanszék
}

\begin{abstract}
Absztrakt.
Célkitüzések: az emlörákban való megbetegedés túlélésében szerepet játszó öt pszichoszociális tényező jelentőségének vizsgálata, amelyek a szakirodalomban publikált eddigi adatok fényében relevanciával bírnak e kór alakulása szempontjából.

Módszer: félig strukturált interjúk segítségével megpróbáltuk feltárni azokat a stresszkeltő életeseményeket, amelyek hatással lehettek a megkérdezett személyek betegségének kialakulására, illetve azokat a múlt és jelenbeli adott eseményekhez fúződő társas kapcsolatokat, amelyekre a megkérdezettek támaszkodtak betegségükkel szembesülve. Érdeklődtünk továbbá az emlőrákkal való megküzdés módozatai, a veszteségek kontrollhitéröl és rákérdeztünk a személyek életcéljaira.

Eredmények: megkérdezettjeink többsége szembesült egyfajta stresszor jellegü történéssel, veszteségélménnyel megbetegedése előtt. Egyetlen kivétellel, mindannyian részesültek a társas támogatás valamilyen formájában. A megküzdési stratégiák közül a legtöbben a vallást illetve a spirituális hitben való megnyugvást tartották a legjárhatóbb útnak. Szinte kétharmad részük külső kontrollhitesnek bizonyult és a velük való történéseket
\end{abstract}

\footnotetext{
${ }^{1}$ E tanulmány ,A mellrák pszichoszociális vonatkozásainak vizsgálata daganatos betegek körében" címü szakdolgozat alapján készült. A cikk szerkesztése során a szakirodalmi részt összefoglaltuk, a kutatásból pedig csak a megkérdezettek vallomásait tartalamzó idézeteket hagytuk ki.
} 
felsőbb hatalmaknak, többnyire Istennek tudták be. Életcéljaik középpontjában pedig a család és szeretteik illetve egészségmegőrző-program útmutatásainak követése és ezek általi életstílus-változtatás állt.

Következtetések: sikerült kimutatni a vizsgált öt pszichoszociális tényezőnek a szerepét az emlőrákban való megbetegedés túlélésében illetve a betegek életminőségének alakulásában.

Kulcsszavak: pszichoszociális tényezők, jelentős életesemények, társas kapcsolatok, coping-stratégiák, kontrollhit, koherencia érzés és életcélok.

Abstract. Purpose of the article: To examine the importance of five psychosocial factors in breast cancer survival that are, according to the published literature, relevant to the development of this disease.

Methodology: We conducted semi-structured interviews with a sample of participants to assess the stressful life events that might have influenced the onset of the disease, as well as to identify the social support in connection to past or present events that the participants could rely upon when faced with the disease. Furthermore, participants were asked about the methods they had used to cope with breast cancer, experiences of a sense of loss, the extent to which they believed they can control the events that affect them (locus of control) as well as the individuals' life goals.

Findings: Most participants reported having been exposed to certain stressful events or having suffered loss prior to the onset of the disease. Almost all of them received some kind of social support. As regards coping strategies, most of the participants found comfort in religion or spirituality. Nearly two thirds of the respondents had a prevalent external locus of control, attributing events to God or higher powers. As for their life goals, most participants mentioned family and loved ones, as well as adopting health promotion programs and a healthier lifestyle.

Conclusions: We have demonstrated the role of the examined five psychosocial factors in breast cancer survival and their impact on the development of the patients' quality of life.

Keywords: psychosocial factors, significant life events, social relationships, coping strategies, health locus of control, sense of coherence, life goals.

A rákos megbetegedések szerte a világon a harmadik leggyakoribb elhalálozási okként vannak nyilvántartva a fertőző megbetegedések, és a szív- és érrendszeri megbetegedések után. Mondhatnánk úgy is, hogy a rák népbetegség, valamint korunk egyik legnyomasztóbb népegészségügyi problémája (Ferlay és munkatársai 2006).

Az Egészségügyi Világszervezet jelentése szerint 2005-ben 502.000 nő halt meg világszerte emlőrákban. Prognózisuk a 2010-es évekre még elkeserítőbb 3:1 arányban fog az emberiség rákban megbetegedni. 
Egy széles körben elterjedt felfogás szerint a rákos megbetegedések kialakulásában a pszichológiai tényezők jelentős szerepet játszanak, és e kór előrehaladásában a stressz, a depresszió, a szociális elszigetelődés valamint a megküzdési stílusok nagy jelentőséggel bírnak (Lemon és munkatársai 2004). A kutatások jelenlegi állása szerint azonban nincs elegendő bizonyíték ezekre (Edelman 2005). Azt viszont kimutatták, hogy a pszichológiai tényezők növelhetik a rákos megbetegedések kockázatát, amikor ezek és más vulnerabilitás tényezők - mint például a meghitt, bizalmas emocionális támasz hiánya - együtt járnak (Price és munkatársai 2001). Mára már számos szakember elismeri, hogy a pszichológiai vonatkozások figyelembevétele és a pszichológiai problémák kezelése a rákos betegek terápiájának fontos elemeit képezik (Massie és Holland 1990).

A diagnózis, a betegség hosszú-, és rövid távú következményei - mint például a mell eltávolítása, a kemoterápia vagy sugárkezelés, a rosszullét, a fájdalom, a hányinger, a hajhullás, stb. -, a betegséggel szembeni attitüd, valamint azok a megküzdési stratégiák, amelyekhez a személy folyamodik, olyan tényezők, amelyek befolyást gyakorolhatnak a túlélésre (Szabó 2001).

Edelman és munkatársainak (1999) vizsgálatai, melyek az életminőség javítását és az élettartam meghosszabbítását célozták, összefüggést találtak a stresszkeltő életesemények, a depresszió, a személyiségbeli sajátosságok és azon megküzdési stratégiák között, amelyek a betegség kialakulását befolyásolhatták. Ebből kifolyólag, indokoltnak tartottuk ezen pszichoszociális tényezők kutatását, mivel az eddigi vizsgálatok arra utalnak, hogy leggyakrabban ezek mutatnak statisztikailag kimutatható összefüggést a daganatos megbetegedés különböző vonatkozásaival.

A Rákosok Román Egyesületénél 2009-től hetente müködik² támasznyújtó, önsegítő csoport kolozsvári, mellrákos nőknek, melynek egyik legfontosabb célkitüzése a csoportszellem, a hovatartozás illetve az egymás támogatás érzésének kialakítása. Klinikai szakpszichológus szupervíziója alatt próbáljuk meg az érintettek gondolkodását, életszemléletét átformálni és a pozitív gondolkodás rejtelmeit elsajátíttatni velük. Programjaink között szerepelnek még szabadtéri tevékenységek (séták, kirándulások), különösebb fizikai megterhelést nem igénylő mozgás-programok, ergoterápiás tevékenységek (kézimunka, rajzolás, festés, kerámiából dísztárgyak, ékszerek készítése). A spirituális hitben érdekeltekhez pedig havonta egy ortodox pap is ellátogat.

\footnotetext{
${ }^{2}$ Suta Erika vezetésével
} 


\section{Stresszkeltő életesemények}

A stressz mindennapjaink velejárója és kellemetlen életesemények illetve életünk negatív történései közepette döbbenünk csak rá ártó hatására. A mód, ahogyan sikerül elboldogulnunk vele, valamennyiünk számára más és más. Sokan csak akkor tulajdonítanak neki jelentőséget, amikor már negatív tüneteket produkál egészségük szempontjából. Különösképp így van ez a daganatos betegségben szenvedők esetében.

A jelentős életesemények a legfontosabb stresszorok között szerepelnek. Ezek között a traumák különlegesen fenyegető életesemények, melyek lassan gyógyuló „sebeket” ejtenek a velük való találkozáskor. A Holmes és Rahe (1967) által kidolgozott életesemény-skála 43 olyan akut stresszforrást, traumát foglal magába, melyek közül a szeretett személy halála, egy súlyos betegség, munkahelyelvesztés az elsők között szerepel. Ezért jut nagy jelentőség ezeknek az eseményeknek a feldolgozására. Ugyanis a „gyászoló személyeknél nagyobb valószínüséggel alakulnak ki daganatok a halálesetet követő években” Stauder (2007:161).

A mindennapi kellemetlenségek (,daily hassles”) szorosan kapcsolódnak az egyén egészségét veszélyeztető tartós stressz állapotokhoz. Kanner és munkatársai (1981) szerint a leggyakrabban előfordulók a családtagok egészségi állapotához, az alapvető szükségleteket kielégítő javak árának emelkedéséhez, az otthon fenntartásához, a túlterheléshez, illetve a különböző tárgyak elvesztéséhez vagy megtalálásának nehézségeihez kapcsolódnak.

A stressznek a rákos megbetegedésekben játszott szerepét mindenekelött a Simonton és feleségének Matthews-Simonton szerzőpárosnak sikerült meggyőző erővel igazolnia, akik a terminális fázisban lévő rákos betegek hagyományos gyógykezelését egészítették ki egy olyan pszichológiai beavatkozással, mely a stressz csökkentése által az immunrendszer megerösítését túzi ki célul. 1978-ban megjelent Getting Well Again címü könyvük, akárcsak terápiás eredményeik elismerése (melyek a legjobb amerikai rákkórházakhoz képest kétszer, az országos átlaghoz viszonyítva háromszor jobbak!), módszerüket világviszonylatban ismertté tették (Capra 1982; Siegel 1993 és 1995; Vargha 1995).

\section{A mellrákhoz való viszonyulás}

A rossz hírre való reagálás kortól, iskolai végzettségtől, lakóhelytől függően mindenkinél másképp történik (Balega 2006). A leggyakoribb reakciók a kezdeti sokkos állapot során a kétségbeesés, a talaj elvesztése a lábuk alól, a magukba fordu- 
lás és a depresszív állapotba kerülés. Ezért az onkológiai team elsődleges célja a beteg pszichéjének ,hadrendbe állítása” a betegség elleni harc során, hisz a beteg gyógyulni vágyása nélkül a leghatékonyabb gyógyító módszerek is csődöt vallhatnak. A felvilágosítást a beteg pszichés teherbíró képességéhez is illeszteni kell, ami idő- és empátiaigényes feladat. A megfogalmazás árnyaltságával, tapintatos stílussal, egyenes beszédünkkel nem elbizonytalanítani szándékozunk a beteget, csupán megnyerni öt a betegség elleni küzdelemre. A ködösítés, a tények mellett való elbeszélés bizonytalanságot okozhat, mely ronthatja a gyógyulás esélyeit. A rossz hírre agresszióval reagálókhoz is türelemmel kell lennünk; ugyanis az agresszió a nehéz helyzetre adott válaszreakció (Balega 2006).

A betegséghez való viszonyulás az első pillanattól kezdve a legmeghatározóbb szempontok egyike. Fontos, hogy a személy e kórt betegségnek tekintse és nem ,átoknak, büntetésnek, szégyennek”, de különösképp nem „,halálos ítéletnek”. (Sontag 1983; Riskó 1999 nyomán) Az orvos szerepe szintén meghatározó, hiszen „ő mondhatja ki a főként kezdetben szinte kimondhatatlant a szorongó, érzelmi krízisben lévő, kommunikációs képességeiben gyakran gátolt betegnek: «önnek rosszindulatú daganatos betegsége van»» Riskó (1999:38).

Riskó (1999) szerint a kétségbeesés fázisából való kimozdulás után beindul az életben maradás ösztöne: a betegséggel szemben a páciens vagy küzdő magatartással vagy tagadó hozzáállással fog viszonyulni. Ez pozitívan értékelhető és ezeknek a betegeknek nagyobb az esélyük a gyógyulásra, mint a reményét vesztő, beletörődőnek, aki megadja magát a betegségnek.

\section{A daganatos beteg támogató rendszere}

A rák pszichoszociális tényezői szempontjából fontos számon tartanunk, hogy a betegség túlélésében meghatározó szerepet játszik az adott betegségben szenvedő személy körüli szociális támasz és hogy a különböző típusú támasz milyen forrásból érkezik. Példának okán a személyek információ jellegü konkrét támaszt várnak el a szakemberektől, míg az ugyanilyen jellegü segítséget a hozzátartozók részéröl manipulációként veszik. Utóbbiaktól ugyanis az emocionális támaszt igénylik.

Sokaknak könnyebb hasonló problémákkal küzdő személyektől igénybe venni. A szociális támasz típusú segítségnyújtás elfogadására azonban szinte képtelenek az olyan személyek, akik nem szociábilisak, illetve képtelenek szociális kapcsolatokat fenntartani vagy biztosítani azok kielégítő minőségét, akik maguk sem segítenek másoknak, amikor problémákkal szembesülnek, nem tudják megfogalmazni segítség iránti igényüket, vagyis akiknek kommunikációs problémáik vannak. Berkman és Syme (1979) vizsgálatai azonban kimutatták, hogy a 
kisebb szociális támogatottsággal rendelkezőknél, a halandóság rátája magasabbnak mutatkozott azokkal szemben, akik szélesebb körü szociális támaszt élveztek (Holland 1990).

Team-munkával azonban a betegek életminősége nagymértékben javítható és elkerülhetők olyan súlyos érzelmi következmények, mint a megváltozott testkép elfogadhatatlansága. Ez húzódhat meg a mellrákos nők partnerkapcsolatainak megromlásának hátterében is, amely a legfontosabb támogató rendszerek egyike. Az önértékelés csökkenése, a krónikus fáradtságérzet és a libidócsökkenés mind hozzájárulnak ahhoz, hogy a mellrákos nők rövidebb-hosszabb ideig lemondanak a testi közelségről még akkor is, amikor ezekre az együttlétekre nagyon nagy szükségük lenne (Riskó, 1999). Ha a nőiesség képe csorbát szenved, ez időleges, illetve végleges visszahúzódást eredményez a partnerüktől, melyre számos esetben a férfiak is rásegítenek. A legfontosabb lelki támaszt nem egy külső szakember, hanem az élettársnak kellene adnia. Ennek azonban - még a betegség kialakulása előtt - egy kiegyensúlyozott, kölcsönös szereteten alapuló, jól múködő partnerkapcsolat elengedhetetlen feltétele (Riskó, 1999).

\section{A megküzdési stratégiák alkalmazása}

A külső környezetből érkező segítség is hatástalan maradhat azonban, ha a személy nem viszonyul megfelelőképpen a betegségéhez és az ezzel való megküzdéshez. Bármilyen coping stratégiát is alkalmazzon a személy, a lényeg, hogy az átsegítse öt a daganatos betegség következtében kialakult nehéz életszakaszon és megmutassa neki 'a fényt az alagút végén'.

Maslow (1970) szerint a megküzdés:

- célirányos és motivált,

- a külső környezet és a kulturális tényezők által meghatározott,

- az esetek jelentős részében tanult viselkedésformákat mozgósít,

- könnyebben ellenőrizhetö, mint az expresszív viselkedés,

- általában változást igyekszik elöidézni a környezetben és ebben a célkitüzésében gyakran sikeres is,

-jellemző módon eszközjellegü magatartás, amelynek célja a szükségletek kielégítése vagy a fenyegetés csökkentése,

- tipikusan tudatos viselkedés, bár idővel nem tudatossá válhat,

- általában erőfeszítéseket feltételez a személy részéről (Vargha, 2011 nyomán). 
Lazarus és Folkman (1984, 1991) a megküzdés két alapvető funkcióját különböztetik meg: a stresszt előidéző probléma kezelését vagy megoldását, illetve a problémára adott emocionális válaszreakció szabályozását. A megküzdés e két formája nem zárja ki egymást, inkább facilitáló hatást gyakorolnak egymásra, bár a helyzet - vagy még inkább annak egyes elemei - adottságaitól függően egyik vagy másik közülük előtérbe kerülhet (Vargha 2011 nyomán).

Ha a személy negatív elterelő stratégiákat alkalmaz, izolálódhat környezetétől és a huzamosabb ideig tartó önsanyargatás megakadályozhatja abban, hogy lépjen saját helyzete megváltoztatása érdekében. A túlzott mértékü alkoholfogyasztás, az önmagára is veszélyes cselekvési módok illetve a másokra irányuló agresszió csak tovább rontanak a helyzetükön (Sárváry 2011).

„Hasznos, és a betegség későbbi szakaszára jellemző megküzdési stratégia a konkrét, rövid távú célok felállítása, illetve a távolabbi célok mentális feltérképezése, elővételezése. Ezek a célok azt sugallják a betegnek, hogy van miben bíznia. Végül sokak számára rendkívül nagy segítséget adó megküzdési forma a pozitív jelentés keresése, vagyis az értékek átrendezése, a korábban háttérbe szorult vagy kevésbé értékelt tevékenységek felfedezése” Sárváry (2011:123).

\section{A kontrollhit és a mellrák alakulásának viszonya}

A személy egészségkontroll-mintájának feltárása azért bír jelentőséggel a daganatos betegség pszichoszociális tényezőinek megismerése során, mert azok a betegek, akik rendelkeznek megfelelö kontrollhittel, és úgy érzik, hogy képesek uralni az életükben bekövetkező történések alakulását, nagy valószínüséggel negatív következmények kialakulása nélkül élik majd meg azokat a negatív emóciókat, amelyek felléphetnek az onkológiai kezelések alatt.

$\mathrm{Az}$ Amerikai Egészségügyi Intézetek (National Institutes of Health - NIH) megfogalmazása szerint a kontrollhit "azoknak az egymással összefüggésben álló meggyőződéseknek és elvárásoknak az együttese, amelyek arra vonatkoznak, hogy egyrészt a személy képes úgy cselekedni, hogy ezáltal megvalósítsa az elvárt eredményeket, másrészt arra, hogy a környezet a személy igényeinek megfelelöen fog viselkedésére reagálni” (Shapiro és Astin 1998:22).

Amennyiben az egyén úgy fogja fel a megerősítést, mint valamilyen cselekedete következményét, de ugyanakkor úgy találja, hogy az nem egészen az ő tevékenységétől függ, akkor azt a mi kulturviszonyaink között, úgy értékeli, mint szerencsét, mázlit, végzetet, külső erők keze nyomát vagy elöre nem látható eseményt, mivel a körülötte nyüzsgő erőtényezők igen bonyolultak (Phares 1987). Az események ilyen módon való értelmezését külső kontrollhitnek nevezzük. Ezzel szemben, ha az egyén felfogása szerint az események saját maga- 
tartásának vagy viszonylag állandó jellemvonásainak folyományai, azt belső kontrollhitnek nevezzük.

A külső és belső kontroll hatással van a jóllétre és az egészségre is. Eisenberger és Cameron (1996) szerint a személyiségfejlődés során a kontroll és a motiváltság szoros kapcsolatban áll egymással. A belső kontrollal rendelkező személyek döntéseit belső motiváltságuk irányítja és lehetőséget ad számukra személyiségük kiteljesedésére és kreativitásuk kiélésére, míg a külső kontrollal rendelkezők mások elvárásaihoz alkalmazkodnak, és külső szabályrendszereknek kívánnak megfelelni, mely által belső személyiségfejlődésük akadályozottá válik.

A kontrollhit az, amely a betegség kialakulásához vezethet, de ez fordítva is igaz. Ahogy az embernek a betegsége alakul, úgy módosulhat a kontrollhite is. Lehet, hogy valaki kiindul egy nagyon domináns belső kontrollhitből, ami arra vonatkozik, hogy ő meg van győződve arról, hogy minden úgy történik, ahogy ő alakítja a dolgokat.

A tanult tehetetlenség a kontrollvesztésre adott reakciók során a legsúlyosabb probléma, ugyanis a személy úgy észleli a helyzetet, hogy saját viselkedésének semmilyen hatása nincs a helyzet kimenetelére. Különösen magas fokú tehetetlenséget mutattak ki a szakértők krónikus betegségekben szenvedőknél, ahol a fájdalom, a mozgáskorlátozottság, az egyedüllét és a megváltozott élethelyzet elfogadása jelenthet nehézséget.

Antonovsky a koherencia érzéseként határozta meg azt az alapvető beállítódást, amelyik szerint az élet legkülönbözőbb eseményei valamilyen okból kifolyólag következnek be és még akkor is felismerhető valamilyen logika, felsőbb hatalom vagy grandiózus terv kontrollja, ha nem rendelödnek alá feltétlenül az egyén ellenörzésének (Amirkhan és Greaves 2003). A koherencia érzése ellentmond annak a cinikus szemléletnek, amelyik a világot a kiszámíthatatlanság, a káosz és az abszurdum által uraltként fogja fel (Antonovsky 1993). Azok a személyek, akik rendelkeznek az élet értelmébe vetett hittel és az ez által kreált pozitív érzelmi állapottal, profitálnak az olyan egészségvédő faktorokból is, mint a közösségi kapcsolatok erössége, a vallás, a civil szférában való részvétel és új személyközi kapcsolatok kiépítése. Ezek mindegyike a jóllét kialakításának egyik alapkövét képezi. 


\section{Életcélok az emlők daganatos megbetegedésében szenvedők körében}

A daganatos betegségben szenvedőknél is fontos, hogy tüzzenek maguk elé közeli, rövid távú, középtávú és egyesek hosszú távú célokat, melyek saját értékeikre alapozva kiteljesíthetik az életüket, a mindennapjaikat és motiválhatják őket a megvalósításban. Céljaink elérésének viszont elengedhetetlen feltétele a hajlandóság és áldozatvállalás is. Számos beteg bevállalja azt a rengeteg mellékhatást, amely az onkológiai kezelésekkel együtt jár, mert bíznak abban, hogy ezáltal meghosszabbíthatják életüket. A pozitív gondolkodás segíthet nekik ebben. Jótékony hatása nemcsak a jelen életeseményei során mutatkozik meg, hanem a jövőre vonatkozó vágyainkban, elvárásainkban is.

\section{Minta}

A kutatásban résztvevő vizsgálati személyek olyan mellrákos nők, akik Romániában élnek, jórészük Kolozsváron, míg mások az ország más megyéiben. Közös bennük, hogy a múltban mindannyian a kolozsvári Onkológiai Intézetben voltak kezelve. A személyek kiválasztásánál nagyon vigyáztunk arra, hogy interjúalanyaim életében minimum két év elteljen azóta, hogy befejezték az onkológiai kezelések egy részét, a sugár- és kemoterápiát. (A tablettás hormonkezelés egyeseknél öt évig is eltart.)

A megkérdezett személyek egyharmada a Rákosok Román Egyesületénél működő - korábban már említett - önsegítő csoportba járt. Az ország más részéből származókkal azokon a napokon készült az interjú, amikor épp a periodikus egészségügyi állapotukat felmérő vizsgálatokra jöttek Kolozsvárra.

A legfiatalabb nőbeteg életkora 38 év volt - a legidősebb pedig 74 éves. Ezáltal a vizsgálati személyek átlagéletkora 56 évre tehető.

A vizsgálatba eredetileg 40 személyt szándékoztunk bevonni, de végül csak 30 személy válasza került feldolgozásra. Tíz személyt pszichés állapotuk súlyosságából kellett mellőzni, mivel zaklatott lelkiállapotuk miatt kontraindikáltnak tartottuk a felkavaró témákat magába foglaló meginterjúvolást. 


\section{Módszer}

A kutatás módszere félig strukturált interjú volt, melyek kérdéseit öt pszichoszociális tényezö köré csoportosítottam.

Az első témakör a stresszkeltö életesemények voltak. Itt arra voltunk kíváncsiak, hogy a daganatos betegségük kialakulását megelőzően, milyen események történtek a megkérdezettek életében, amiről úgy gondolták, hogy megterhelhették őket lelkileg és hozzájárulhattak betegségük kialakulásához.

A második kérdés-kategória a múltbeli, adott eseményekhez kapcsolódó és jelenre vonatkozó társas kapcsolataikat célozta meg. Válaszaikból azt szerettük volna megtudni, hogy kik voltak azok a személyek, akiknek szociális támaszára számíthattak illetve fordultak-e lelki segítő szolgálatok szakembereihez. Megpróbáltunk fényt deríteni azokra a személyekre, akik pozitív hatást gyakoroltak a betegségükkel való megküzdés során, de érdekeltek azok is, akiket esetleg elveszítettek megbetegedésükből kifolyólag.

A harmadik kérdéskör azon megküzdési stratégiák feltérképezésére irányult, amelyekhez a vizsgált személy folyamodott betegsége során. Itt azok után a coping-mechanizmusok után érdeklődtünk, amelyek rendelkezésére álltak úgy testi, mint lelki szinten és hogy mennyire volt ezeknek hatásuk a kór leküzdése során.

A negyedik kategória azokat a kontrollhittel kapcsolatos kérdéseket foglalta magában, amelyek válaszaiból kiderülhetett, hogy a vizsgált személy külső vagy belső kontrollal jellemezhető inkább. Érdekeltek továbbá e kérdéskörben a vizsgált személyek Antonovsky (1993) koherencia érzésével kapcsolatos elgondolásaik; hogy szerintük a világban van-e rend vagy csak a kiszámíthatatlanság és a káosz uralkodik-e mindenütt.

Az utolsó öt kérdés azokra az életcélokra vonatkozott, amelyeket az emlők daganatos megbetegedésében szenvedők tüznek maguk elé és próbálják azokat megvalósítani.

\section{Célkitüzések és hipotézisek}

1. A jelentős életesemények témakör kapcsán megfogalmazott célok:

a) azoknak az eseményeknek a felkutatása, amelyek nagy megpróbáltatásnak tették ki a személy alkalmazkodási képességét és ezáltal közrejátszhattak a daganatos betegségek kialakulásában;

b) a történteknek érzelmi síkon való megélésének megismerése és annak felderítése, ahogyan ez az esemény befolyásolta életük további alakulását. 


\section{Hipotéziseink:}

a) a megkérdezettek többsége be fog számolni stresszor jellegü történésről a rákos betegség kialakulása elött;

b) ezek a történések súlyos, személyiségük fejlődése szempontjából negatív hatást gyakoroltak rájuk.

\section{A társas kapcsolatok témakör célkitüzései:}

a) a szociális támasz jellegü múltbeli, adott eseményekhez kapcsolódó, illetve jelenre vonatkozó személyek körének feltárása, akik támogatást nyújtottak a betegek számára;

b) a megkérdezettek igényeltek-e lelki segítséget professzionális szakemberektől, és ha igen, akkor milyen segítséget vártak tőlük.

\section{Hipotéziseink:}

a) a vizsgált személyek nagy többsége rendelkezik a szükebb/tágabb családja támogatásával, mely által könnyebben elboldogultak betegségükkel;

b) csak kevesen fordultak professzionális segítőhöz pszichés problémáikkal.

\section{A coping stratégiák témaköre kapcsán célkitüzéseink:}

azoknak a megküzdési módoknak a feltárása, amelyeket betegséggel való megküzdés során alkalmaztak és hogy mennyire hittek ezek hatékonyságában.

Hipotéziseink: az érintettek elsősorban érzelmi stratégiákat alkalmaztak. Sokan fordultak anyagi támogatásért családjukhoz, barátaikhoz, mivel a hosszú hónapokig tartó kezelések többségüket nagymértékben megterhelhette anyagilag. Fontos lehetett számukra minden olyan információforrás, amely hasonló helyzetben lévő személyektől érkezett, és amely hozzájárulhatott a betegségükkel való megküzdés elősegítéséhez.

4. A kontrollhit vizsgálatával kapcsolatos célok:

a) annak azonosítása, hogy megkérdezettek külső vagy belső kontrollhitüek-e;

b) annak megismerése, hogy mennyire érezték magukat tehetetlennek az onkológiai kezelés időtartama alatt;

c) annak feltérképezése, hogy a vizsgált személyek hogyan vélekednek arról, hogy a világ dolgait a rend vagy a zürzavar és a káosz határozzák-e meg. 


\section{Hipotéziseink:}

a) a megkérdezett személyek külső kontrollhelyesek és szorongással válaszolnak stresszkeltő életeseményekre;

b) azok a nők, akik részesültek különösképp kemoterápiában - függetlenül a daganat természetétől illetve a mellükben való elhelyezkedéstől -, a kezelés időtartama alatt átéltek kisebb-nagyobb fokú tehetetlenségi érzést;

c) a tanult tehetetlenség érzése világszemléletükre is ráteszi bélyegét; a környezetükkel kapcsolatos negatív elvárások és a jövőjükre vonatkozó negatív előfeltételezésekből kiindulva, a világban történtekben is csak a bizonytalanságot és a káoszt érzékelik.

5. Az életcélokkal kapcsolatos célkitűzéseink:

a) a megkérdezettek jövőre irányuló elképzeléseikre, és azok megvalósíthatóságára vonatkoztak;

b) a céljaik megvalósítása érdekében tett hajlandóságuk.

\section{Hipotézisek:}

a) a vizsgált személyek - a nagymértékü félelmeikböl kifolyólag - az egészségük visszaállításán kívül, nem mernek célokat tüzni maguk elé és szorongással telve tudnak csak jövőjükre gondolni.

b) céljaik megvalósítása érdekében - lehetőségeikhez mérten -, mindannyian valamilyen egészségvédő programokba kezdenek és ezekbe teljes mértékben hisznek is.

\section{Eredmények}

\section{Az életesemények témakör eredményei}

E témakör kapcsán a válaszokat - a Holmes és Rahe (1967) életesemény-skála alapján azonosítottuk be és öt fö kategóriába csoportosítottuk őket, melyek a következők: „stresszhelyzetek”, „,veszteségélmények”, „biológiai háttér”, „,betegségélmény” és a „nehézséget jelentő anyagi változások” (1. sz. táblázat). 


\begin{tabular}{|c|c|c|c|}
\hline \multirow{2}{*}{\multicolumn{2}{|c|}{ Életesemények }} & \multicolumn{2}{|c|}{ Gyakoriság } \\
\hline & & Fö & Százalék \\
\hline \multirow{3}{*}{ Stresszhelyzetek } & családon belüli stressz & 9 & $30 \%$ \\
\hline & munkahelyi stressz & 3 & $10 \%$ \\
\hline & tágabb környezet / szomszéd & 1 & $3,33 \%$ \\
\hline \multirow[t]{2}{*}{ Veszteségélmény } & elhalálozás & 7 & $23,33 \%$ \\
\hline & elköltözés & 1 & $3,33 \%$ \\
\hline \multicolumn{2}{|c|}{ Biológiai háttér (öröklődés, hormonkezelés) } & 7 & $23,33 \%$ \\
\hline \multicolumn{2}{|c|}{ Betegségélmény (közeli családtagé) } & 4 & $13,33 \%$ \\
\hline \multicolumn{2}{|c|}{$\begin{array}{l}\text { Nehézséget jelentő anyagi változások (saját ill. közeli } \\
\text { családtag munkahelyelvesztése) }\end{array}$} & 3 & $10 \%$ \\
\hline
\end{tabular}

1. táblázat Az életeseményekkel kapcsolatban kapott leggyakoribb válaszok.

A vizsgálat személyek életében a legtöbb stresszkeltő életesemény családon belül történt. Túlnyomórészt ( 9 esetben) párkapcsolati konfliktusokat és családtagokkal való heves vitákat említettek ezzel kapcsolatban. A második leggyakoribb életesemény, amely rátehette bélyegét rákos diagnózisukra, egy szeretett személyek elhalálozása illetve - egy esetben - a gyermek külföldre való költözése volt. Nyolc személy szerint ez váltott ki olyan veszteségélményt bennük, amelyet aztán betegségük okának tudnak be. A biológiai háttérből (öröklődés, hormonkezelés miatti) származó betegség kialakulásának valószínüségét hét beteg említette meg. Négyen hormonkezelés következményeként hiszik, hogy daganatos betegek lettek, míg hárman nagy valószínüséggel anyai ágon örökölhették (édesanyjuk is mellrákos volt, illetve lánytestvérük is ebben szenved). Öt esetben közeli családtag (férj, szülő) betegsége (féloldali paralízise), valamint az ő állandó (éjjel-nappali) gondozása vezetett odáig, hogy saját személyüket teljesen elhanyagolva megbetegedjenek rákban. Három személyt pedig annyira megviselt lelkileg a saját illetve a közeli családtag munkahely elvesztése és az ebből adódó anyagi nehézségek, hogy „teljesen belebetegedtek”. A harminc megkérdezett személyből az összes negatívan (elkeseredettséggel, szorongással) élte meg a történéseket. Csak két olyan személlyel találkoztam, akik úgy érezték, hogy szerintük lelki tényezők nem játszottak közre a betegség kialakulásában. Az ő esetükben a diagnózis kialakulását hormonkezelésnek tudták be az orvosok.

Arra a kérdésre, hogy a betegség hogyan befolyásolta életük további alakulását, 21 személy negatív változásról beszélt és csupán 7 személynek értékelődött át pozitívan az élete a rákos diagnózis után. Míg ketten úgy tartották, hogy semmilyen hatással nem volt rájuk. Mára már csak 19-en tekintenek vissza borúlátóan megbetegedésükre (két vizsgálati személy ugyanis már elhalálozott). A hét pozitívan gondolkodó mellett négy olyan interjúalanyunk volt, akik úgy érezték, hogy életük azóta is ugyanolyan maradt. 


\section{A társas kapcsolatok témakör eredményei}

A témakörben kapott válaszok megerősítették annak fontosságát, amit a társas támogatás megléte jelenthet a daganatos betegek életében. Legyen az családtag, barát, szomszéd, kolléga, főnök vagy csak egy jó ismerős, amennyiben kimutatták pozitív érzéseiket és támogatásaikat a megkérdezetteknek, hozzásegítették őket ahhoz, hogy érezzék, „nincsenek egyedül” ebben az életükért folyó küzdelemben.

Ahogy a 2. számú táblázat számadataiból is kitünik, szinte mindannyian rendelkeztek informális (Csabai és Molnár 2000) szociális támogatórendszerrel, amelyben a velük való törődés és róluk való gondoskodás a szeretet egyik megnyilvánulási formája.

\begin{tabular}{|l|c|c|}
\hline \multicolumn{1}{|c|}{ Szociális támasz formái } & \multicolumn{2}{c|}{ Gyakoriság } \\
\cline { 2 - 3 } & Fó & Százalék \\
\hline Család & 27 & $90 \%$ \\
\hline Barátok & 7 & $23,33 \%$ \\
\hline Szomszédok & 2 & $6,66 \%$ \\
\hline Egyéb személy (fónök, kollégák, mások) & 4 & $13,33 \%$ \\
\hline Egyedül & 1 & $3,33 \%$ \\
\hline Szakemberhez fordultak volna & 19 & $63 \%$ \\
\hline Nem tartottak igényt külső támogatásra & 11 & $36,6 \%$ \\
\hline
\end{tabular}

2. táblázat A társas támogatást nyújtók körének gyakorisága.

Az esetek nagy többségében nem elhanyagolható az anyagi segítség sem, melyben a vizsgált személyek részesültek a többhónapos kezelések ideje alatt. Sokuk számára ekkor derült ki, hogy kik azok a személyek, akik feltétel nélkül szeretik őket, és akikért érdemes tovább folytatni a harcot e betegséggel.

Ami a morális segítő szakemberek (pszichológus, szociális munkás, pap) szolgáltatásainak igénybe vételét illeti, 19-en (63,3\%) igényeltek volna pszichés támogatást különösképp a betegségük kezdetén, de szakember hiányból kifolyólag nem volt ilyenre lehetöségük. 11-en $(36,6 \%)$ nem tulajdonítottak ennek különösebb jelentőséget. (Fontosnak tartjuk megemlíteni, hogy a kolozsvári Onkológiai Intézetben csak tavalyelöttől alkalmaznak pszichológust. Addig - önkéntesként - túlnyomórészt a szerzők egyike (Suta Erika) nyújtott számukra lelki támaszt és lehetőséget az érzelmi ventillációra.) 


\section{A coping stratégiák témakör eredményei}

A megküzdési stratégiák a betegséggel kapcsolatos kérdéskörre a válaszokat öt fő coping-típus köré soroltuk, melyek a következők: „hit és a vallásgyakorlás”, „,aktív megküzdés”, „emocionális szociális támasz felhasználása”, ,instrumentális szociális támasz felhasználása”, és a „pozitív gondolkodás”.

A megküzdési mechanizmusok eredményei a COPE-skála (Carver és munkatársai 1989) alapján lettek csoportosítva (3. sz. táblázat).

\begin{tabular}{|l|c|c|}
\hline \multicolumn{1}{|c|}{ Coping-típusok } & \multicolumn{2}{c|}{ Gyakoriság } \\
\cline { 2 - 3 } & Fó & Százalék \\
\hline $\begin{array}{l}\text { Vallás illetve spirituális hitben való meg- } \\
\text { nyugvás találás }\end{array}$ & 14 & $46,6 \%$ \\
\hline $\begin{array}{l}\text { Aktív megküzdés (a gyógyulás érdekében } \\
\text { tett lépések, elfoglaltság, munkaterápia) }\end{array}$ & 14 & $46,6 \%$ \\
\hline $\begin{array}{l}\text { Emocionális szociális támasz felhasználá- } \\
\text { sa (család, gyerekek, unokák) }\end{array}$ & 12 & $40,0 \%$ \\
\hline $\begin{array}{l}\text { Instrumentális szociális támasz felhaszná- } \\
\text { lása (információ-kérés, szakemberekhez } \\
\text { fordulás, anyagi segítség) }\end{array}$ & 9 & $30,0 \%$ \\
\hline Pozitív újraértelmezés és növekedés & 9 & $30,0 \%$ \\
\hline
\end{tabular}

3. táblázat Az alkalmazott coping-csoportok eredményei.

Ebben a skálában szereplő megküzdési típusok voltak azok, amelyeket legközelebbinek tartottuk azokhoz a megküzdési módokhoz, amelyekhez a daganatos betegek folyamodnak a leggyakrabban. A megkérdezettek pedig szinte szórólszóra idézték e skála válaszlehetőségének szavait.

A hit és a vallásgyakorlás volt a leggyakrabban alkalmazott megküzdési mechanizmus a betegek körében. A megkérdezettek szinte fele (14-en / 46,6\%) hitt abban, hogy a vallásos szertartásokon való részvétel, az ima és a böjtök átsegítik majd öket betegségük folyamatán. Ennek feltehetően az is oka lehet, hogy a megkérdezett személyek szinte kétharmada román anyanyelvü és így túlnyomórészt ortodox vallású.

Ugyanez az arány mutatkozott az aktív megküzdéssel kapcsolatosan is. Azzal, hogy a betegek elterelték figyelmüket a betegségükről, többet foglalkoznak saját személyükkel és megváltozott az életstílusuk (azóta egészségesebben étkeznek, rendszeresen tornásznak, sétálnak, stb.), hobbijaiknak élnek (kézimunkáznak, olvasnak, virágokat gondoznak, stb.) bebizonyították, hogy „rák-túlélők”-ként is létezik tovább élet. 
Az emocionális szociális támasz felhasználása / a család, a gyerekek és unokák / $12(40 \%)$ személy számára jelentette az élet értelmét és adott nekik erőt ahhoz, hogy harcoljanak e kórral.

Az instrumentális szociális támasz (a különböző szakemberekhez való fordulás és azok tanácsának követése, a hasonló helyzetben lévőktől való információkérés illetve az anyagi támogatás) 9 megkérdezettnél (30\%) szerepelt a legfontosabb megküzdési stratégiák között.

A pozitív gondolkodás (a betegségének egy más, pozitív fényben való feltüntetése, helyzetének átértelmezése és az abból való tanulás) szintén 9 személy (30\%) válaszai között szerepelt.

A harminc megkérdezett személyből 27 (90\%) hitt teljes mértékben a saját maga által választott megküzdési technikákban és csupán $3(10 \%)$ inogott meg ez irányú hitében.

\section{A kontrollhittel kapcsolatos kérdéskör eredményei}

A kontroll helyével kapcsolatos válaszokat három csoportba foglaltuk (4. táblázat).

\begin{tabular}{|l|c|c|}
\hline \multirow{2}{*}{ Kontroll-típusok } & \multicolumn{2}{c|}{ Gyakoriság } \\
\cline { 2 - 3 } & Fó & Százalék \\
\hline Felsőbb hatalmak (Isten) & 19 & $63,3 \%$ \\
\hline Sors / szerencse & 10 & $33,3 \%$ \\
\hline Saját életük irányítói & 7 & $23,3 \%$ \\
\hline
\end{tabular}

4. táblázat A megtörtént események alakulása feletti kontroll a megkérdezettek körében.

Kategóriáink illeszkednek Antonovsky (1993) koherencia-elméletének üzenete köré, mely szerint vagy valamilyen felsőbb hatalom vagy a sors és szerencse közjátékának köszönhetjük azt, ami életünk során megtörténik velünk. Míg mások „saját sorsuk kovácsaik”.

A megkérdezett személyekből 19-en (63,3\%) hiszik azt, hogy akárcsak életük, így megbetegedésük is „Isten”től származik. Tízen $(33,3 \%)$ hiszik, hogy sors és szerencse közjátéka az egész életük. Míg saját életük irányítójának csupán 7-en $(23,3 \%)$ tartják magukat. Ennek ellenére $26(86,6 \%)$ szerint a hétköznapokban saját kezükben van a kontroll. Betegségük további alakulása 28 személynél $(93,3 \%)$ is saját maguk által meghatározott. A megkérdezettek között csak 2-en (6,66\%) gondolják azt, hogy ez Istentől illetve orvosától függ. Az 
onkológiai kezelés mellékhatásaival való szembesülés során 17-en (56,6\%) érezték magukat tehetetlennek. Tíz személy $(33,3 \%)$ soha nem engedte el magát. Három $(10 \%)$ vizsgálati alany állította azt, hogy néha nem tudta uralni helyzetét.

\section{Az életcélokkal kapcsolatos témakör eredményei}

Az életcélokkal kapcsolatos elképzeléseket a megkérdezettek részéről három kategóriába soroltuk, melyek a következők: családdal kapcsolatos célok, egészségmegőrzés valamint munka és egyéb tevékenységek (5.táblázat).

\begin{tabular}{|l|c|c|}
\hline \multirow{2}{*}{\multicolumn{1}{|c|}{ Életcélok }} & \multicolumn{2}{c|}{ Gyakoriság } \\
\cline { 2 - 3 } & Fö & Százalék \\
\hline Családdal kapcsolatos célok & 16 & $53,3 \%$ \\
\hline Egészségmegőrzés & 15 & $50 \%$ \\
\hline Munka és egyéb tevékenységek & 5 & $16,6 \%$ \\
\hline
\end{tabular}

5. táblázat Az életcélok rangsorolása daganatos betegeknél.

A vizsgálati személyek között 17 olyan nő (53,3\%) volt, akiknek életcéljaik megváltoztak és átrendeződtek a betegségük után. Tizenhárom fónél $(43,3 \%)$ viszont változatlanok maradtak. A megkérdezettek közül 15-en (50\%) konkrét cselekedeteket tesznek céljaik megvalósítása érdekében, 12-en (40\%-uk) egészségük megőrzése érdekében konkrét életvitelen belüli változtatásokra hajlandó. És csak 3 személy (10\%) jelezte, hogy nem mer célokat állítani maga elé, mivel annyira szorong a jövőtől. Céljaik megvalósíthatóságában hisznek 27-en (90\%), melynek érdekében konkrét lépések megtételére is hajlandóak.

\section{Következtetések}

Holland (1998) a rákot ,kaotikus sejtburjánzás”nak tartja, melynek több mint 200 fajtája ismert. Behatolva az épp szövetek közé, áttételeket hozhat létre a nyirokrendszerben, a vérben és ezáltal a test más részeiben is daganatok alakulhatnak ki. Wingate és Wingate (1988:91) szerint a rák ,a páciens saját szöveteinek parazita formája". Bármelyik meghatározás is áll hozzánk közelebb, daganatos betegségben szenvedőkkel foglalkozó szakemberként nem hagyhatók figyelmen kívül azok a - pszichoonkológia által már számos tanulmányban megfogalmazott - pszichoszociális tényezők, amelyek közrejátszhatnak e kórral való 
megküzdésben és hozzásegíthetik az érintetteket a „ráktúlélők” számának növeléséhez szerte a világban.

A stresszkeltö életeseményekkel kapcsolatban megfogalmazott mindkét hipotézisünk beigazolódott, ugyanis a megkérdezettek többsége valóban átélt stresszor jellegü történést a daganatos betegségének kialakulása előtt. Legyen az családon belüli, munkahelyi vagy tágabb környezetbeli stresszhelyzet vagy akár egy közeli személy elhalálozásával kapcsolatos veszteségélmény, a megkérdezett célcsoport úgy tartotta, hogy ez közrejátszhatott daganatos betegségének kialakulásában. Elenyésző százalékuk egy közeli hozzátartozó megbetegedését élte meg stresszkeltő eseményként vagy anyagi változások beálltának tulajdonított negatív mértékben olyan jelentőséget, hogy ezek bekövetkezését tartották betegségük kiváltó tényezőjének. A harminc megkérdezettből heten a mellükben kialakult rosszindulatú daganatot örökletes eredetünek tartották, illetve olyan nagy adag hormonkezelésnek tudták be, amelynek következtében alakult ki szervezetükben a rosszindulatú sejtbúrjánzás. E témakör kapcsán szinte teljes mértékben megerősitést nyert második hipotézisünk, mely szerint ezek a történések személyiségük fejlődése szempontjából nagymértékủ negatív hatást gyakoroltak rájuk. Csupán két olyan személy volt, akit e kór nem kifejezetten viselte meg lelkileg; ők hormonkezelésük utóhatásaként betegedtek meg.

A társas támogatás témakörön belül szintén beigazolódtak hipotéziseink, mivel csupán egyetlen személyt találtunk, akinek teljesen egyedül kellett megküzdenie betegségével. Az ő számára nem áll(hatot)t rendelkezésre sem rokon, barát, jószomszéd, de még egy kívülálló ismerős sem, akivel megoszthatta volna e betegséggel kapcsolatban kialakult terheit. A többiek - még ha nem is részesültek anyagi támogatásban is -, de legalább rendelkezésükre állt az emocionális támasz által nyújtott érzelmi ventilláció lehetősége. Amennyiben megadatott volna, szinte kétharmaduk örült volna morális segítséget nyújtó szakember támogatásának, különösképp a diagnózis hallatán, illetve az azt követő lelkileg nehezen elviselhető periódusban. A többiek beérték a család részéröl érkező szeretettel és odafigyeléssel. Introvertált személyiségükből eredően, nem tartottak még arra sem igényt, hogy külső személlyel osszák meg e betegséggel kapcsolatos érzéseiket.

A coping stratégiák területén megfogalmazott hipotéziseink nem igazolódtak be. Megkérdezettjeink az érzelmi és anyagi támogatás elé a vallást, a spirituális hitben való megnyugvást helyezték, illetve az aktív megküzdés azon megnyilvánulását, mely szerint konkrét lépéseket kell tenniük gyógyulásuk érdekében. Emellett ergoterápiás tevékenységeket folytattak. Meglepően kevesen kérték ki 
sorstársaik véleményét a betegséggel való megküzdéssel kapcsolatban, mint ahogy a pozitív gondolkodás sem volt gyakori körükben.

A kontrollhittel kapcsolatos hipotéziseink azonban alátámasztást nyertek. Kétharmaduk külső hatásoknak (túlnyomórészt „Isten általi büntetés”nek) tulajdonították betegségüket. Ennek következtében - tartva az ismeretlen ráhatásoktól túlnyomórészt félelemmel és szorongással reagáltak az öket körülvevő történésekre. Nagyobbrészük - a kemoterápiás kezelésük időtartama alatt - bizonyos fokú tehetetlenségi érzést is átélt. Egyetlenegy személy sem volt, akiben fellelhető lett volna Antonovsky koherencia-érzése. Még a három - viszonylag - pozitívabban gondolkodó nőbeteg sem hitte, hogy a világban rend és törvényszerüség lenne. Véleményük szerint a körülöttünk lévő világban történő eseményeket az esetlegesség, a véletlen és a káosz határozzák meg.

Az életcélokkal kapcsolatos hipotéziseink nem igazolódtak be. Csupán három olyan személlyel beszéltünk, akinek betegségével kapcsolatos félelmei olyan nagy mértéküek voltak, hogy semmilyen célt ne merjen maga elé tüzni és csak szorongással telve tudott volna jövőjére gondolni. A nagytöbbség azonban vagy családjaikkal kapcsolatos célokat tüztek maguk elé, vagy olyan egészségmegőrző-programokba kezdtek, amelyekben teljes mértékben hittek is és ezek megvalósítása érdekében konkrét lépések megtételére is hajlandóak voltak.

Patricia Fobair (2007) elgondolásaiból kiindulva és írásának útmutatásait követve arra a következtetésre jutottunk, hogy egy nő számára a mellrák és annak következtében eltávolításra kerülő emlő(k)ről való „lemondás” az egészségpszichológiai kutatások és ezen belül megfogalmazott biopszichoszociális modellben központi helyen szereplö és ugyanakkor az egyik legkomplexebb témakör. Ugyanis más szervekben (mint például torokban, tüdőben, májban, gyomorban, bélben, de még a női nemi szervekben) kialakuló rosszindulatú daganatos sejtbúrjánzás sem jár annyira összetett pszichoszociális következményekkel egy NÖ számára, mint a mellrák. Számos olyan negatív emocionális reakcióval társul az érintettek életében, mely úgy a munkájukhoz való visszatérés megakadályozását eredményezheti, mint a magánéletükben kialakuló válságnak, számos esetben válásnak is a kiváltója lehet. $\mathrm{Az}$ e területen dolgozók és a pszichoonkológia kérdéskörével foglalkozók mindmáig nem találtak egy olyan bármely nő számára járható utat jelentő - választ, amely káros emocionális következmények nélkül hozzásegítené öket az - esetek túlnyomó többségében eltávolított emlö(k) 'elengedésé'hez. 


\section{Javaslatok}

Az onkológiai betegekkel foglalkozó szociális munkásoknak jelen kell lenniük, amikor a daganatos betegek szükségét érzik, hogy e kórral kapcsolatos félelmeikről beszélhessenek valakivel, és akinek támaszával képesek legyenek a kezelési tervük minden egyes lépésének véghezvitelére. A szociális munkás számos feladatot vállalhat segítőként, képzettségének megfelelően. Közvetítő szerepet tölthet be a beteg és az onkológiai team tagjai között. Jogi képviseletet elérésében segítheti a betegeket. Kézzelfogható erőforrások - anyagi támogatások és más juttatások - felkutatását is vállalhatják, és esetenként részt vehetnek szakmai elhelyezkedési gondjaik megoldásában. Meg kell tanítaniuk a betegeket arra, hogy - szükség esetén - rámenősek is legyenek. Segíthetik öket abban, hogy pl. szerepjátékok keretén belül megtalálják a számukra legmegfelelőbb kommunikációs módot családtagjaikkal, orvosaikkal. Megbeszélhetik velük magánéletbeli problémákat, és ha szükséges, pszichológushoz irányíthatják őket. Megtaníthatják őket életstílus-változtatásra az onkológiai kezelés után. Önsegítő csoportokat szervezhetnek nekik. Felkutathatnak számukra olyan szervezeteket, ahol a ráktúlélők önkéntes munkát végezhetnek. Később, ha úgy alakul, és betegségük kiújul, segíthetik őket a számukra legmegfelelőbb hospice- és palliatív tevékenységeket nyújtó szervezetek elérésében. A terminális fázisban lévők és azok családtagjai mellett pedig biztosíthatják a gyásztanácsadást (Patricia Fobair 2007 nyomán).

Tepperwein (1992:174) szerint a daganatos megbetegedések kialakulását „személyes tragédia, csökkent ellenállóképesség illetve belső elszigeteltség" idézi elő, és esetünkben az emlőrák a partnerkapcsolat (házastárs, barát, gyermekek, munkahelyi főnök vagy tanár) szellemi-lelki téren történő zavarát jelenti. Ugyanez a szerző hisz abban, hogy ,,egészségi állapotunk életvezetésünket tükrözi vissza” és ,(...) a betegség mindig csupán jelzés, mely az éppen követett út megváltoztatására szólít fel”, meg kell fogadnunk a szerző tanácsait és „módosítanunk kell életvitelünkön”. Tepperwein (1992:175)

Ennek érdekében az egyik legfontosabb lépés az egészséges táplálkozás. A National Cancer Institute ,Eating Hints - Before, During and After Cancer Treatment" kiadványában részletes útmutatót találhatnak az érintettek arról, ahogy táplálkozzanak az onkológiai kezelések ideje alatt és után.

Bagdy Emőke (2007:263) az egészségmegőrzés három alappillérét „a pozitív, optimista beállítottságban, a társas támogatottságban és az adaptív megküzdési módok birtoklásában" látja. A természetes életerő-fejlesztő, ún. vitalitásgenerátorok között említi az életderüt, a fizikai élénkséget és a testi kontaktust, melyek 
együtt „hozzájárulhatnak az immunrendszer stimulálásához és az örömhormontermeléshez." (2007:246)

Egészségünk megőrzése érdekében Pennebaker (2005) a naplóírás jótékony hatására esküszik, míg Langner (2002) a halálfélelmünk leküzdése érdekében a legmegfelelőbb viselkedési módnak tartja a kreatív tevékenységeket (a múvészetet, a zenét és az írást), a szeretetet, a humort, az önsegítő csoporthoz való tartozást, a vallást, a sportot, a kirándulást.

Mindmáig nem létezik ,aranyszabály” arra vonatkozóan, hogyan lehet ezt egy nőnek sikeresen feldolgozni. Mindannyian különböző személyiségjegyekkel bírók, így a velük való foglalkozás a szakemberek részéről is elengedhetetlenné teszi egy személyreszóló segítőprogram kialakítását és annak lépésről-lépésre való formálását.

Hitvallásunk szerint, élhet az a mellrákos nő földrajzi szempontból az USAban vagy Oroszországban, Kelet- vagy Nyugat-Európában, egyazon - világszerte alkalmazott onkológiai eljárásokat magába foglaló - protokollrendszer által kezelt. A túléléséért folytatott küzdelemben csupán az különböztet meg egy magyar vagy román nőt egy ausztráliaitól, ahogyan képes megbírkózni e kórral és továbbélni „ráktúlélő”-ként. A lényeg azonban, hogy ne maradjanak egyedül a betegségükkel. Lehetőséget kell teremtenünk számukra úgy az egyéni mint a csoportban történő érzelmi ventillációra és meg kell találnunk számukra a legmegfelelőbb módot arra, ahogyan ,ráktúlélőként” minőségi életet élve a lehető leghosszabb ideig közöttünk maradhassanak.

\section{Irodalomjegyzék}

1. Bagdy Emőke (2007): Vitalitásgenerátorok. Szubjektív jóllétérzésünk erősítésének és egészséggondozásunk természetes eszközei. In: Kállai János, Varga József, Oláh Attila (szerk.): Egészségpszichológia a gyakorlatban. Medicina Könyvkiadó Zrt., Budapest. 239-273.

2. Balega János (2006): Onkopszichológia. In: Molnár Emma, Füredi János, Papp Zoltán (szerk.): Szülészet-nőgyógyászati pszichológia és pszichiátria. Medicina Könyvkiadó Rt., Budapest. 151-156.

3. Carver C.S., Scheier M.F. and Weintraub, J.K. (1989): Assessing coping strategies: A theoretically based approach. Journal of Personality and Social Psychology, 56, 267-283.

4. Csabai Márta, Molnár Péter (szerk.) (2009): Orvosi pszichológia és klinikai egészségpszichológia, Medicina Kiadó, Budapest. 74-170. 
5. Edelman S. (2005): Relationship between psychological factors and cancer: An update of the evidence. Clinical Psychologist, Sidney, Australia. 9. 2. 45-53.

6. Ferlay J., Autier P., Boniol M., Heanue M., Colombet M. and Boyle P. (2006): Estimates of the cancer incidence and mortality in Europe in 2006. Oxford Journal. Medicine. Annuals of oncology. 18. 3. 581-592.

7. Fobair P. (2007): Oncology Social Work for Survivorship. In: Ganz P.A. (ed.): Cancer Survivorship - Today and Tomorrow, Springer Science + Business Media, LLC New York, USA. 14-27.

8. Green B., Lindy J. D. and Grace M.C. (1985): Posttraumatic stress disorder: toward DSM-IV. Journal of Nervous and Mental Diseases, 173: 406-411.

9. Langner T.S. (2002): Choices for living. Coping with Fear of Dying. Kluwer Academic Publishers, New York, Boston, Dordrecht, London, Moscow. 8-12.

10. Lemon J., Edelman S. and Kidman A.D. (2004): Perception of the „mindcancer" relationship by members of the public, cancer patients and oncologists. Journal of Psychosocial Oncology. 21. 43-58.

11. Massie M.J., Holland J.C. (1990): Depression and the cancer patient. Journal of Clinical Psychiatry. 51. 12-19.

12. Pennebaker J.W. (2005): Rejtett érzelmeink, valódi önmagunk. Háttérkiadó, Budapest. 43-63.

13. Price M.A., Tennant C.C., Batow P.N., Smith R.C., Kennedy S.J., Kossoff M.B. and Dunn, S.M. (2001a): The role of psychosocial factors in the development of breast carcinoma: Part II. Life event stressors, social support, defense style and emotional control and their interactions. Cancer. 90. 4. 686-697.

14. Riskó Ágnes (1999): A test, a lélek és a daganat. Animula Kiadó, Budapest. 21-81.

15. Sárváry Andrea (2011): Egyén a családban - A családpszichológia alapjai. Debreceni Egyetemi Kiadó, Debrecen. 138-140.

16. Stauder Adrienne (2007): Stressz és stresszkezelés. In: Kállai János, Varga József, Oláh Attila (szerk.): Egészségpszichológia a gyakorlatban. Medicina Könyvkiadó Zrt., Budapest 153-176.

17. Szabó Krisztina Gabriella (2001): A pszichoszociális tényezők szerepe a rákos megbetegedésekben. Erdélyi Pszichológiai Szemle., Románia 2. 1. 69-90.

18. Szabó Krisztina Gabriella (2011): Pszichoneuroimmunológia és pszichoonkológia. In: Vargha Jenő László: Egészségpszichológia, Egyetemi Jegyzet, Babeș-Bolyai Tudományegyetem, Kolozsvár, Románia. 82-125.

19. Tepperwein K. (1992): Mit árul el betegséged? A tünetek nyelve. HungaPrint Nyomda és Kiadó, Budapest. 173-178. 
20. Vargha Jenő László (2011): Kontrollhit. In: Vargha Jenő László: Egészségpszichológia, Egyetemi Jegyzet, Babeş-Bolyai Tudományegyetem, Kolozsvár, Románia.

21. www.cancer.gov: Eating Hints - Before, During and After Cancer Treatment. Support for People With Cancer. National Cancer Institute. U.S. Department of Health and Human Services.

Suta Erika: Egészségügyi szociális munkás

Rákosok Román Egyesülete - Kolozsvár

Sárváry Andrea: pszichológus, főiskolai docens

Debreceni Egyetem Egészségügyi Kar, 4400 Nyíregyháza, Sóstói u. 2-4. 


\section{UNIVERSITY \\ OF DEBRECEN}

FACULTY OF

HEALTH

NYÍREGYHÁZA

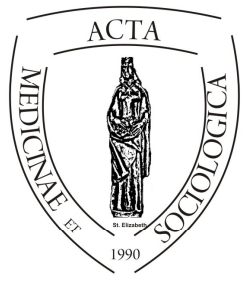

ACTA

MedSoc

VOLUME 5.

2014

\title{
Rendszerszemléletü és narratív megközelítések alkalmazása a terápiában
}

Esetismertetés

Bojti István

Pszichoterapeauta, belgyógyász orvos

\begin{abstract}
This paper deals with the therapy of a mother and her son. First we undertook a system-oriented approach; however, this process has stalled. The main reason this therapy stalled seemed to be the strong emotional commitment that the system approach was unable cope with, in this particular case. This difficulty was overcome by changing to constructivist narrative therapy. This paper introduces in detail the narratives of family members, the selection criteria for the narratives to be looked at, the externalization, and the ethical issues arising in the course of the therapy. We recognise the difference between the systemic family therapy approach and the narrative approach, within the framework of the Integral Theory, devised by Ken Wilber. According to his theory, the view of reality of the systemic approach, which is inherently striving for objectivity, and the constructivist therapeutic attitude, bearing in mind the client's subjective view of reality, are two alternative interpretations of the same reality. In this case the subjective approach proved more effective.
\end{abstract}

Keywords: family terapy, system oriented approach, narrative approach 
Összefoglalás. Az alábbi tanulmányban egy anya és fia terápiáját mutatjuk be. Munkánk során kezdetben rendszerszemléletü megközelítést alkalmaztunk, ez a folyamat azonban elakadt. Úgy tünt, ennek oka a rendszerszemlélet által aktuálisan nem feldolgozható erős érzelmi elkötelezettség volt. Az elakadást a konstruktivista narratív terápiára váltással sikerült feloldani. Részletesen tárgyaljuk a családtagok narratíváit, a feldolgozandó narratívák kiválasztásának szempontjait, az externalizációt, a terápia során felmerülő etikai kérdéseket. A rendszerszemléletü és a narratív megközelítés különbségét a Ken Wilber nevéhez kötődő integrál elmélet keretei között értelmezzük. Eszerint a rendszerszemlélet eredendően objektivitásra törekvő valóságszemlélete és a kliensek szubjektív valóságát szem előtt tartó konstruktivista terápiás attitüd ugyanazon valóság két alternatív értelmezése. A bemutatott eset a szubjektív megközelítés prioritására hozott példát.

Kulcsszavak: családterápia, rendszerszemléletű megközelítés, narratív megközelítés

\section{Bevezetés}

A segítő munkában folyamatosan nehéz sorsú emberekkel dolgozunk. A sikerrel nem vagyunk elkényeztetve. Nem csoda, hogy a terápiás rendszereknek nagy keletje van. Egy olyan család terápiáját kívánom bemutatni, ahol két alapvetően különböző módszert, a rendszerszemléletü családterápiát, majd ennek eredménytelensége után a narratív terápiát alkalmaztam. Írásomban a két módszer összehasonlítására törekszem.

\section{Rendszerszemlélet}

A rendszerszemlélet nagyon népszerü a családterápiában, de nem csak itt, hanem az egész modern társadalom- és természettudományban is. Lépten-nyomon találkozunk ugyanis olyan jelenségekkel, ahol nagy számú elem kerül egymással sokrétü kölcsönhatásba, és jó lenne a folyamatot megérteni és befolyásolni. Ez a bonyolult feladat nem oldható meg a részek külön-külön leírása és ezek összegzése révén. A kísérlet eleve kilátástalan lenne.

A rendszerszemlélet a problémát úgy oldja fel, hogy a vizsgálni kívánt jelenséget egy egyéni tulajdonságokkal rendelkező önálló egésznek tekinti (László E. 2001). Ezt a konstrukciót nevezzük a továbbiakban rendszernek.

A rendszerszemléletű pszichoterápiák mintegy fél évszázados múltra tekintenek vissza, és több irányzatra oszlanak. Közös bennük a modernista alapállás: a családot és a patológiás tünetet a rendszerszemlélet fogalmaival értelmezik, és a terapeuta az ,objektív” külső szakértő. A terapeuta gondosan megtervezett intervenciókkal a rendszer paraméterein kezdeményez változtatást, mely visszahat a 
családtagok tapasztalatára, a tanulás lehetőségét teremti meg, és ez vezet a kívánt cél eléréséhez (Goldenberg és Goldenberg 2008).

A jelenségek rendszerszemléletü értelmezése a szokásos individuálistól eltérő nézőpontot kíván meg. A következőkben a rendszerek elemzéséhez szükséges néhány patamétert veszek sorra. Szem előtt tartom, hogy írásomban egy családterápiás esetről lesz szó, ezért az itt használatos fogalmakra fókuszálok, és egy családot tekintek a rendszernek (Goldenberg és Goldenberg 2008, Minuchin 1974).

A rendszerszemlélet nem az egyénre, hanem a kölcsönhatásra figyel. A kölcsönhatások felmérése informál a személyek kapcsolati hálójáról és a kapcsolatok minőségéről. A kölcsönhatások kommunikációt jelentenek,és ebben az értelemben számítsuk ide azt is, hogy a viselkedésnek, vagy néha akár a betegségnek is van kommunikációs jelentése. A kommunikáció megfigyelése az információk és a beavatkozási lehetőségek gazdag tárházát nyitja meg a terapeuta számára.

Alrendszerek. Egy családban lehet többféle alrendszer: szülők, gyermekek, házastársak, férfiak, nők, dominánsak, alárendeltek stb. Az alrendszerek fogalma akkor válik a terápiában jelentőssé, ha egy probléma értelmezésében célszerüek. Például egy gyermekeit szorosan kontrolláló szülő esetében megállapíthatjuk, hogy a gyermeki és a szülői alrendszer határai elmosottak, mert a szülő a gyermek feladatait részben átvállalja.

A határok. Ha rendszerekről, alrendszerekről beszélünk, akkor ebből következik, hogy kellenek határok. A családok esetében ez vonatkozhat térbeliségre (helyiségek funkciója, nyitott ajtók, együtt alvás stb.), az információáramlásra, a feladatmegosztásra, a jogokra, pénzügyekre stb. Lehetnek a határok merevek vagy ennek ellentéteként összemosottak, a középutat tiszta határoknak nevezzük. Ebben az esetben mindenki számára egyértelmü, hogy hol húzódnak a határok, és milyen szabályok szerint lehet ezeket megváltoztatni. A határok gondos elemzésével legtöbbször az egész családi patológia lenyomatát és intervenciós felületet kapunk.

A hierachia. A hierarchiában az van felül, akinek az akarata érvényesül. Tehát egy problémás személy, aki körül a család élete forog, ebben az értelemben a családi hierarchia csúcsán van. A pozíció változhat. Például egy agresszív részeg ember a hierarchia csúcsán van, másnap józanon, elviselve a családtagok szemrehányását a hierarchia legaljára kerül.

Szabályok. Nagyon fontos, részben kimondott, részben ki nem mondott a család életét meghatározó alapelvekről van itt szó, amelyek mélyen gyökereznek, nemegyszer több generációra nyúlnak vissza. Például: „A mi családunkban mindenki szorgalmasan dolgozik”. „Csak akkor tudok Neked segíteni, ha őszintén mindent elmondasz". A szabályok határozzák meg a rendszer eddig felsorolt jellemzőit is. 
Trianguláció. Amikor két személy a konfliktusát egymás között nem tudja megoldani, akkor előfordulhat, hogy az egyikőjük, vagy akár mindketten is egy további személyt a saját oldalukon bevonnak a konfliktusba. Nem csak egy családtagról lehet szó, a terapeuta is gyakran célja az ilyen törekvésnek. A háromszemélyes helyzetben kevesebb feszültség van, mint a diádikusban. A terápiás kapcsolatra nézve azonban súlyosan destruktív.

A rendszerszemléletủ családterápiában hasznosnak bizonyult néhány eredetileg a kibernetikában megalkotott fogalom. A családi rendszer homeosztázisa fenntartásában például szükséges a negatív visszacsatolás. Amikor két családtag a már számtalanszor lefolytatott vitába ismét belemegy és egyre indulatosabbá válnak, akkor a pozitív visszacsatolás eredményét látjuk. Mind a negatív, mind a pozitív visszacsatolás a lineáris okság modelljét követi. A családi folyamatokat a cirkuláris okság azonban legtöbbször pontosabban modellezi. Eszerint egy családtag tette a többi családtagra is hat, akik ezt a hatást saját újabb interakcióikban továbbadják, és a tovagyưrüző hatás eléri az első családtagot, és így tovább. Végül is ezen szemlélet jegyében nincs értelme az eseményeknek valamilyen kitüntetett kezdetét, azaz okát keresni, mert a tyúk vagy a tojás problémájához lyukadnánk ki. Az okok helyett a rendszer fenti jellemzőinek elemzése kínálkozik a beavatkozás lehetőségeként.

Végül az első és másodrendü változás fogalmát szeretném szóba hozni. A családtagok folyamatosan arra törekednek, hogy problémáikat megoldják. Az elért változásokat a rendszemlélet fent részletezett fogalmaival elemezhetjük. Az elért változást akkor tekintjük első rendünek, ha olyan kis mértéküek, hogy a fenti rendszer jellemzők változatlanok maradnak. Például egy szenvedélybeteg fiatalember megígéri, hogy többször nem fog inni, és az anyja eldugja a pincekulcsot. A másodrendű változás a rendszer fenti jellemzőinek a megváltozását jelenti. Például a fiatalember elköltözik otthonról és önálló életet kezd. A családi életciklusok közötti váltás eseteiben másodrendủ változásokat kell megvalósítani. Ennek elmaradásával sok terápiát igénylő konfliktus értelmezhető.

Szeretném kiemelni, hogy a rendszert leíró fenti paraméterek viszonylag objektívnek tekinthetők. Kevéssé a családtagok vagy a terapeuta szubjektív értékelésén alapulnak, inkább egy külső megfigyelő által megszerezhető információnak felelnek meg. Megismerésükhöz nem szükséges bonyolult értelmezésekbe bocsátkoznunk. (Wilber 2009) A pszichoterápiás gyakorlatban a rendszerszemléletnek ez az objektív jellege természetesen ennyire „tisztán” nem érvényesül, illetve a konstruktivizmus felé történő elmozdulásnak lehetünk a tanúi. Erre még később visszatérek. 


\section{Posztmodernitás.}

A filozófia posztmodern forradalma (Wilber 2009) elveti a modernitás korábbi koncepcióját, miszerint létezik egy objektív valóság, ami kívülálló nézőpontból, objektív tudományos módszerekkel kitartóan kutatva feltárható. A posztmodern felfogás szerint a megismerő is része a megfigyelt jelenségnek. Ezért a megismerés során szerzett információk a megismerő által mindig „,szennyezettek”, és ebből az következik, hogy a megfigyelötől függetlenül létező objektív valósággal nincs értelme számolni. Mint ahogyan ugyanaz a futballmeccs is egészen más aszerint, hogy a nyertes vagy vesztes csapat szurkolójaként figyeljük.

\section{A posztmodern korszakot a megismerés fejlődése kényszerítette ki.}

A fizika világából két példát említek meg: a kvantummechanika bizonytalansági relációját, miszerint egy részecske helye és sebessége egyidejüleg tetszőleges pontossággal nem határozható meg; a kozmológiában pedig arra a tételre utalok, ami szerint egy rendszer jelenlegi állapotához többféle megelőző történet tartozhat, amikhez különböző valószínűség rendelhető. Szó sincs egyik esetben sem egy objektív bizonyosságról.

A társadalom jelenségei hétköznapi tapasztalatainkhoz még közelebb állnak. Európában az elmúlt kétszáz évben a korábban a keresztény vallás által meghatározott homogén világkép széttöredezett. Ehelyett párhuzamosan létező egymásnak ellentmondó értelmezések sokasága tartja magát érvényesnek - és minden bizonnyal érvényesek is, attól függően, hogy kinek a szempontjából vizsgáljuk. Csak az individualizmus-kollektivizmus példáját említem meg, ahol az egymásnak ellentmondó igazságokra asszociálhatunk. Ugyanis az egyéni vagy a csoportérdek prioritásának dilemmájában valószínüleg mindenki tudna mindkét oldal mellett meggyőzően érvelni. A posztmodern szemlélet értelmezési keretet próbál adni egyre bonyolultabb világunknak.

\section{Konstruktivizmus.}

A konstruktivizmus illetve a szociális konstruktivizmus (Mahoney 2003) posztmodern szemléletü elméletek. Lényegük az, hogy a megfigyelő valóság élménye nem azonos magával a valósággal, hanem annak mentális konstrukciója. Azaz nem a terület maga, hanem egy térkép a területről. E konstrukció nyilván a konstruáló személyétől is függ, és ebben nyilvánul meg a posztmodern jelleg. A szociális konstruktivizmus a konstrukciók kultúra által befolyásolt és alapvetően nyelvi formát öltő jellegét hangsúlyozza (László 2005). Az ember tehát saját magáról, másokról és minden egyébről is azt gondolja, olyan értékeket követ, úgy viselkedik és érez, amilyen mentális konstrukciói vannak. A metafora alapján tehát a térkép a lényeg, nem a terület. A konstrukciók nyelvi karakterük révén megismerhetők, megbeszélhetők, megváltoztathatók. 
Saint-Exupéry és a szociális konstruktivizmus.

Az alábbi részlet A kis herceg című regényből származik. (Ford. Rónay György)

Ha azt mondjuk a fölnötteknek: "Láttam egy szép házat, rózsaszínü téglából épült, ablakában muskátli, tetején galambok..." - sehogy sem fogják tudni elképzelni ezt a házat. Azt kell mondani nekik: "Láttam egy százezer frankot érö házat." Erre aztán fölkiáltanak: "Ó, milyen szép!".

Ez a néhány sor jól illusztrálja azt a jelenséget, amikor a gyermek szocializációja még nem teljes. Még nem tanulta meg a társadalomtól, hogy egy ház konstrukciójának leglényegesebb tartalma a ház ára, és a galambok egyáltalán nem fontosak. A ,tanulatlan” gyermek konstrukciója más tartalmakból épült fel: szín, muskátli, galambok.

\section{Szociális konstruktivista pszichoterápiák.}

Az elmélet új terápiás szemlélet alapját teremtette meg. Vizsgáljuk meg, hogy mihez képest új ez a szemlélet. A pszichoanalízis, a viselkedésterápia, a kognitív pszichológia, a rendszerszemléletű terápiák, és még folytathatnánk a sort a többi modernista irányzattal, részletes modelleket dolgoztak ki a jelenségek értelmezésére a normálisról, a patológiáról, a terápiáról. Ezt az elméletet tekintik a valóság érvényes leírásának. Ebben a keretben helyezik el a klienst, és a rendelkezésre álló eszközökkel igyekeznek korrekciót elérni. A terapeuta itt szakértőként van jelen: az általa alkalmazott elméletnek megfelelően megpróbálja a kliens javulását támogatni.

A szociális konstruktivista terápiák újdonsága abban áll, hogy nem alkotnak meg olyan modellt, ami a kliens valóságát értelmezné. Hiszen ez a modell felfogásuk szerint úgyis torz lenne. Ehelyett a kliens által konstruált személyes valóságra figyelnek. Ebben a világban tájékozódnak, és keresnek olyan fogózókat, amik a kliens számára kielégítőbb konstrukciót eredményezhetnek. Ebben a rendszerben a terapeuta helyzete is más, mint a modernista irányzatok esetében. Itt ugyanis nem a külső szakértő jelleg dominál, hanem a terapeuta inkább résztvevő munkatárs. Közösen dolgoznak a konstrukciókon. A szociális konstrukciók nyelvi jellege miatt a terápiák nyelvezetét tudatosan a kívánt célnak megfelelően formálják (László J. 2005).

A továbbiakban két jelentős karriert befutó terápiás módszert emelek ki: a de Shazer nevével fémjelzett megoldásközpontú terápiát és a narratív terápiát.

A megoldásközpontú terápia (Berg 1991) az előzőekből következően nem fordít nagy figyelmet a probléma eredetére, sőt a részleteire sem. A terápiás aktivitás úgysem ilyen adatok felhasználásából indul ki. Ehelyett a terapeuta azt keresi, hogy a kliens emlékei között melyek azok, amikor a probléma nem állt fenn, vagy kevésbé állt fenn. Ezekben a sikeres időszakokban a kliens mit csinált másként, amit a jelenben is hasznosíthatna? Tipikus a „csoda” kérdés. Ha ma 
éjszaka csoda történne, és megoldódna a probléma, akkor mit csinálna holnap reggel másként? A kérdés célja az, hogy kiderüljön: milyen (feledésbe merült) tudás áll a kliens rendelkezésére a változáshoz.

A narratív terápia (White és Epston 1990) alapgondolata szerint a valóságról alkotott konstrukcióink formailag történetekből épülnek fel (László J. 2008). Ezek a történetek adnak jelentést a tapasztalatainknak. Fontos körülmény, hogy ezeket az életet meghatározó történeteket nem autonóm módon, hanem tekintélyszemélyek közremüködésével társadalmi nyomásra alkotjuk meg. A terápia lényege a meglévő problémás konstrukciók lebontása (dekonstrukció) és adaptívabb konstrukciók létrehozása. Ez a terápiás attitüd szükség esetén támogatja a közvélekedéssel szembeni fellépést, ezek helyébe az egyén saját maga választotta értékeit állítja. Érzékeny az egyén vagy a kisebbségek társadalom általi elnyomására, fontos morális alapállása az elnyomottak támogatása.

A narratív terápia a következö elvi lépésekben zajlik (Kecskeméti 2004):

- a domináns, problémához kapcsolódó, alternatívák nélküli történet megismerése, tudatosítása

- externalizálás -a személyiség és a probléma szétválasztása, a probléma „kihelyezése” nyelvi eszközök tudatos használatával

- dekonstruálás - a domináns történet további összefüggéseinek megértése

- kivételek keresése - az új történet rekonstrukciójához szükséges saját tapasztalatok tudatosítása

- rekonstrukció - új, sokszínü, alternatívákat tartalmazó történet létrehozása.

\section{Az eset ismertetése}

A következőkben a valós személyek azonosítására alkalmas adatokat megváltoztattam.

A család egy szabolcsi faluból származik. Anya még most is ott él, de a 24 éves lánya és a 21 éves fia már Budapesten dolgoznak. A szülők korán elváltak Apa italozása miatt. Apa másik faluba költözött, anyagilag a családot nem támogatta, a személyes kapcsolat is meggyengült, nem találkoznak minden évben. Anya egyedül maradt a két kisgyerekkel. Első munkahelyén, a helyi önkormányzatnál takarít jelenleg is, emellett a háztájiban gazdálkodik. Református vallásúak, rendszeresen járnak a templomba. Anya egész életét arra szánta, hogy a gyermekeiből tanult embert neveljen. Életének stratégiája, hogy ő pénzt nem tud a gyermekeinek adni, de diplomával már elboldogulhatnak az életben. Nem kímélte magát, éjjel-nappal dolgozott. De nemcsak saját magával, hanem a 
gyermekeivel is szigorú volt. Néha elcsattant az anyai pofon, és a gyerekek nem is mertek nem tanulni. Szerencsére okos, szorgalmas gyermekek voltak, hozták a jó jegyeket az iskolából. Harmadik osztályban Laci nagyon tehetségesnek bizonyult matematikából, mert a nővére házi feladatára tudott jó megoldást adni. Tehetséges matekosnak tartotta öt a környezete. A lány orvosit végzett, már férjhez ment, most rezidens. Lacival történt a baj. Gimnáziumba először Debrecenbe járt, kollégista volt. Gondjai voltak a tanulással, rossz jegyeket kapott. Félévkor a kettesért kellett felelnie több tantárgyból is. Az is kiderült, hogy Laci több időt tölt a szórakozással, mint kellene. Édesanyját a kollégiumi dáridók miatt hívták be az iskolába. Otthon nagy veszekedések voltak, ígérgetések, és a nyugtalanító helyzet miatt a második évfolyamra Lacit Nyíregyházára hozta át az édesanyja. Egy éven át itt is kollégista volt, de hasonló problémák miatt harmadik és negyedik évfolyamra az édesanyja kivette a kollégiumból és bejáró tanuló lett, mert így jobban ellenőrizhető volt a napirendje. A rossz helyzet azonban állandósult. Anya mindent megpróbált, hogy a fiát jobb belátásra bírja: fenyegetőzött, büntetett, jutalmazott, Lacit az apjához hasonlította, példaképnek állította a testvérét, de megoldásra nem jutott. Laci egyre inkább csak hallgatott, hazudozni kezdett, ami Anyát leginkább kiborította. Alig várta az érettségit ami közepes eredménnyel sikerült - és felvételt nyert Budapestre egy bölcsész szakra. Itt sem volt eredményes, hamar abbahagyta az egyetemre járást. Barátok, ivászatok, eladósodás következett. Amikor megbetegedett (baleset érte tisztázatlan körülmények között), vagy amikor az adóssága törlesztésére nem volt pénze, akkor testvéréhez, de leginkább anyjához fordult. Anya néha azt érezte, hogy megőrül a stressztől. Számtalanszor utazott el Budapestre, hogy személyesen kifizesse az albérleti díjat, kitakarítsa a szobáját, kifizesse az adósságát. Már akkor görcsbe rándult a gyomra, amikor a mobilján látta, hogy a fia hívja: mi van már megint? Amikor pedig nem hívta, akkor azt várta, hogy mikor fogja hívni. Mindemellett Laci dolgozott, munkahelye stabil volt, és keresetéből nagyon szerényen ugyan, de meg is tudott élni. Ebben az állapotban keresett meg Anya a rendelésemen.

\section{A terápia rendszerszemléletú időszaka.}

Az első ülésen Anya egyedül volt jelen. A problémájukat a rendszerszemlélet keretében az életciklusváltás problémájaként értelmeztem. Eszerint a serdülő gyermek nehézségekbe ütközik, de erre nem a szükséges változások sikeres megvalósításával reagálnak, hanem felemás módon a korábbi struktúra elemeit tartják életben. Fenntartják Laci alárendelt pozícióját: kéri az anyai támogatást, Anya ezt megadja és Laci visszaél vele. Ezek tapasztalatából kiindulva Anya fokozza a Laci feletti kontrollt, ami ellen egyfelől Laci lázad, ugyanakkor a következő percben kiprovokálja azt. Anarchikus szabályok, vitatott hierarchia érzékelhető. Nemhogy tisztulna az anya és fia között lévő határ, hanem minden 
korábbitól jobban összemosódott. Ennek megfelelő házi feladatot határoztunk el. Átgondoltuk, hogy milyen lépésekkel kellene Anyának Laci felé a saját határait megerősíteni. Ennek lényege első lépésben konkrétan az volt, hogy az anyagi támogatás kereteit Lacival beszélje meg, és tartsák magukat ehhez.

Nem akartam triangulálódni, ezért a következő ülésre elhívattam anyával Lacit is.

Ekkor ismerkedtem meg Lacival. Anya vádjait vita nélkül elfogadta. Önértékelése közel olyan alacsony szintű volt, mintha az édesanyjától hallottam volna. Ellenvetése abban állt, hogy a testvére sem olyan ragyogó ember, mint Anya gondolja, ö is megenged magának hajmeresztő dolgokat, csak vele szemben elnézőbbek. Másrészt neheztelt azért, amiért őt olyan okosnak kiáltották ki általános iskolában, nem is volt okos, mindig nagy stresszt jelentett neki megfelelni ennek az elvárásnak. Anya nagyon szigorúan büntette már a négyes osztályzatot is, állandóan félt töle emiatt.

Anya házi feladata erre az ülésre az volt, hogy dolgozzák ki Laci anyagi támogatásának szabályait. E tekintetben szinte semmilyen elörelépés sem történt, és erre számos magyarázattal szolgáltak.

A problémát immár Laci személyes részvételével értelmeztük. Lényegét tekintve a rendszerszemlélet keretei között maradtunk, és a továbblépést is ez határozta meg. Főbb elemei a következők voltak: gyermekkorától mostanáig is szigorú értékrend, magas szintü elvárások, melyek nem feleltek meg Laci igényeinek, illetve képességeinek. A családi kereteket középiskolás korában elhagyta, de jövőképe bizonytalan volt, a kortárs hatások érvényesültek. A felnőtt életének a feltételeit még egyelöre nem sikerült kialakítani. Ezzel kapcsolatos, hogy anyától még mindig függő helyzetben van. Megvizsgáltuk, hogy Lacinak konkrétan milyen lépéseket kell tennie az önálló élete stabilizálása felé és ezzel párhuzamosan Anyával a határok tisztázásában. Összegyüjtöttük azokat a tényeket, amik Laci erejét bizonyítják, és optimista, tevékeny hangulatban ért véget az ülés.

A harmadik ülésre Anya egyedül jött, mert Laci a munkahelyéről nem tudott elszabadulni időben. Néhány átmeneti kedvező tapasztalatot teljesen beárnyékolt az a tény, hogy Lacival 2 napig nem tudott beszélni, és biztos, hogy a rossz társaságában volt és hazudott. Pénzt kért ismét, és ő nem tudott nem adni, mert Laci érzelmileg megzsarolta. Érzi, hogy ilyen érzelmi nyomásnak később sem fog tudni ellenállni, hiszen Lacit ő szülte, és egy szülőnek mindig oda kell állnia a gyermeke mellé, akkor is, ha belepusztul.

Úgy éreztem, hogy nincs jogom ezt az érzést megkérdőjelezni. 


\section{A terápia narratív időszaka.}

A terápia ekkor fordulóponthoz érkezett. Részben azért, mert a rendszerszemléletü értelmezés és az intervenciók láthatóan nem hoztak eredményt, a másodrendű változás elmaradt. Másrészt Laci kimaradása reális veszéllyé vált. Laci és Anya párhuzamosan folyó narratív szemléletű egyéni terápiája mellett döntöttem. A módszerrel kapcsolatos személyes szimpátiám mellett több érv is erősítette a döntésemet:

1. Mindketten könnyen azonosítható elnyomó narratívák szerint értelmezték életük eseményeit.

2. Lacinak nagyon fontos lenne a családja által meghatározott, ránézve idegen és elnyomó narratívát személyesen konstruált másikra cserélnie

3. Laci jelenlegi alacsony motiváltsági szintjét a problémákat kívülre helyező, „felszabadító” hangulatú narratív terápia valószínüleg megerősítené

4. Tekintettel arra, hogy feladatuk kettejük egymásról leválása, a különkülön egyéni terápia ebből a szempontból valószínüleg előnyös lesz.

\section{Anya narratívái.}

Mint általában, Anyának is számos, a konfliktussal kapcsolatos narratívája volt. Felsorolok néhányat.

1. Általában lehet kölcsönt felvenni, de csak nagyon fontos dolgokra. Léhaságra nem lehet pénzt felvenni. Laci ezt megtette, ezért nem komoly ember.

2. A családban a bajok megoldásához elsősorban őszintének kell lenni egymáshoz. Bármi történik, együtt biztosan jobb megoldásokat lehet kitalálni - feltéve, ha öszinték vagyunk egymáshoz.

3. A mai világban a boldoguláshoz vagy sok pénz, vagy egy jó diploma kell. A mi családunk szegény, én nem tudok pénzt adni. Ezért tettem meg mindent, hogy kitaníttassam őket, de Laci nem tette hozzá a magáét, és most kallódik, az élete egy küszködés lesz.

4. Az én életem főmüve ez a két gyerek, az ő boldogságuk. Ha nekik bajuk van, az nekem rosszabb, mint nekik. Az örömük az én örömöm is.

5. Amikor a családban valakinek baja van, akkor segíteni kell ôt mindenáron, hiszen csak egymásra számíthatunk. Laci az elzüllés felé halad, tehát mindent meg kell tennem érte. 
Mielőtt a narratívákkal elkezdenénk a munkát, érdemes alaposan átgondolni a fenti listát, hogy kiválasszuk, melyikkel célszerü dolgozni.

1. Léhaság céljára kölcsönt felvenni. Ez egy olyan gondolat, amit én is vallok, nem tartanám érdemesnek dekonstruálni. A mégis ilyen kölcsönt felvevő ember sommás, végleges elítélése nyilván vitatható, a változásba vetett hit, a megbocsátás kérdéséhez vezet el. Laci és Anya viszonyában az utóbbi releváns kérdés, de nem érzem most a legfontosabbnak.

2. Öszinteség. Ez az elvárás sok konfliktust és kevés eredményt hoz Anya és Laci kapcsolatába. Sok ellenérvet lehetne a feldolgozás során találni, azonban mégsem kívánok vele foglalkozni, mert jelenleg marginális jelentőségü.

3. A jó diploma felemel. A szorgalmas, feltörekvő családok körében különösen gyakran központi jelentőségü narratíva. A sikertelenségét az élet kudarcának minősíteni beszükült értelmezésre utal. A családunk esetében ez tünik az egyik feldolgozandó narratívának.

4. Életem fóműve. Társadalmunkban főleg a hagyományos értékrendü családokban ez az uralkodó diskurzus része. Érvényes ez Anya esetében is. Házasságának megromlása óta, tehát két évtizede életét ez az elv vezérli. Bár ezen narratívának több alternatívája is érvényes lehetne, mély beágyazottsága miatt egyelőre nem kívánok ezzel foglalkozni. Később, a terápia előrehaladása lehet, hogy meghozza ennek a feltételeit is.

5. Családi támogatás. Ez a 4. ponthoz hasonlóan nagyon mélyen beágyazott narratíva, valószínúleg minden emberi kultúrában. Láthatóan Laci családjában is így van. Ennek ellenére ezt a narratívát nem kívánom érintetlenül hagyni, mint az ,életem fömüvét”, hiszen Laci felelőtlen viselkedése, anyjának manipulálása miatt nem lehet őt a felelősség alól tovább felmenteni.

A feltárt narratívák elemzése alapján végül a 3. és 5. számú, ,jó diploma” és „családi támogatás” látszik olyannak, amelyeket a várható nyereség és ellenállás mérlegelése után elsőként dekonstruálni érdemes.

\section{A ,jó diploma" narratíva feldolgozása.}

A narratívák dekonstrukciója első lépésben hagyományosan az externalizálással kezdődik. Ennek során a kliens által átélt, beazonosított probléma illetve tünet külön elnevezést kap, ezáltal a probléma, illetve a tünet külön entitást nyer. Ily módon elkülönül a klienstől, mintegy „,kívülre kerül”, azaz externalizálódik. Ez nemcsak megkönnyebbüléssel és a gyógyulás reményének megmutatkozásával jár, hanem az externalizált problémáról való gondolkozást is új módon teszi lehetővé. Fogunk az externalizálással még találkozni, azonban ennél a pontnál az 
externalizálástól kivézelesen eltekintettem. Externalizálni ugyanis azt a problémát kell, ami a kliensnek elég nagy szenvedést okoz, érzelmileg nagyon megérinti. Meg akar tőle szabadulni. Anya esetében a jó diploma feltétlen szükségessége kérdésében nem éreztem nagyon erős érzelmi elköteleződést, nem okozott már neki nagy szenvedést a diploma hiánya. Ehelyett az alternatívákra nagyobb nyitottságot észleltem. Valószínűleg már elindult az a folyamat, aminek a végére elfogadja Laci képzettségét. A dekonstrukció és az új narratíva rekonstrukciója a következő kérdések mentén történt: Milyen tapasztalatok támasztják alá, hogy a diplomás emberek gazdagabbak, jobb az életük, boldogabbak? Honnan származik erről az információja? Kiket ismer ebből a körből? Mi a különbség a falusi és a városi lakók között e tekintetben? Milyen kivételeket ismer: boldogtalan diplomást és boldog diploma nélkülit? Mit lehet tenni egy nem diplomásnak az élete boldogságáért? Ö mit tett a sajátjáért? Laci mit tett a sajátjáért? Hogy látja, most min dolgozik Laci a boldogsága érdekében? Mi a szülö felelőssége a gyermeke boldogságáért? Az ő szülei és ő, mint gyermek hogy volt ezzel? Ö mit várt el a szüleitől?

A kiindulási narratíva lényege az volt, hogy Laci csak kallódik, az élete egy küszködés lesz. Az ehelyett konstruált új narratíva Lacit küzdőképesnek látja, aki dolgozik a saját sorsának jobbításáért.

\section{A „ családi támogatás” narratíva feldolgozása.}

Anya súlyos szorongást élt át akkor, amikor Laci bajban volt. Hiába tudta, hogy lyukas hordóba tölti a bort, mégis mindig meghozta a kívánt áldozatot a fiáért, hogy kimentse szorult helyzetéből. A terápia első időszakában ennek már magam is tanúja voltam. Úgy érezte, hogy képtelen ellenállni egy érzésnek, miszerint segítenie kell. Logikailag értette, hogy nem jut vele előre, de az érzelmei csak ezt az egy viselkedést engedélyezték számára. Nem volt döntési helyzetben. Ezt a jól körülírható erős érzést externalizáltuk. Aggódásnak nevezte el. Aggódás tehát az a rész, amelyik rákényszeríti őt Laci feltétel nélküli támogatására. Aggódás dekonstrukciója két fő irányban haladt. Egyrészt magát a narratíva tartalmát dekonstruáltuk. Ennek lényege volt, hogy Aggódás Lacinak rövid távon ugyan használ, de hosszú távon árt. Megfosztja Lacit attól a lehetőségtől, hogy a saját kárán tanuljon. Másrészt Aggódás hatalmi hátterét is szóba hoztuk. Aggódással Anya nagyon mélyen azonosult, és egyáltalán nem gondolkodott azon, hogy milyen külső erők hatására alakult ki, és milyen hatalom segíti Aggódás erejét. Aggódás részben a generációkon átívelő minta megjelenése, másrészt nem hanyagolható el a tágabb család, az ismerősök Aggódást támogató föleg vélt, de részben minden bizonnyal valós attitüdje sem. Mit tegyünk, ha egy régi szabály a mi megváltozott körülményeink mellett akar érvényesülni? Mit 
van jogunk a hagyományokon változtatni? Mit kezdünk a felelősséggel, ha eszköztelenek vagyunk? Hogyan oszlik meg a felelősség Laci és Anya között? Anyával összesen háromszor találkoztam két hónapon keresztül a terápia narratív időszakában. Megtanulta a fia zsarolását elutasítani. Laci ezért először nagyon megharagudott rá, de egy héttel később felhívta, és megköszönte.

\section{Laci narratívája.}

Laci története megvalósulatlan reményekröl, kudarckerülésröl, a családja felé méltatlan viselkedéséről, zárt, azaz alternatívák nélküli depressziós jövőképről szólt. Nem tartalmazta az aktív változtatás lehetőségét. Ez a narratíva mindent elborított, mindenütt jelen volt, és csak ez volt jelen. Első lépésben e domináns narratíva kizárólagos létezését kérdőjeleztük meg. Könnyen kiderült, hogy nem csak a gyermekkorában, de már felnőttként is sikeresen küzdött meg nehézségekkel, például helytáll a munkahelyén és van baráti köre. Miután az alternatív narratíváknak is felsejlett a lehetősége, lehetővé vált a domináns depresszív narratívát Laci énképétől magától elkülöníteni, azaz externalizálni. Jól adja vissza ennek lényegét Michael White klasszikussá vált mondata: „A probléma a probléma, és nem az ember".

- Az a benyomásom, - mondtam Lacinak - hogy az Ön lelkében van egy rész, amely állandóan a kudarcokra emlékezteti. És bármit szándékozik Ön tenni, azt duruzsolja a fülébe, hogy az Ön élete már úgyis el van rontva, semmi sem fog már sikerülni.

A probléma és az ember elválasztását nagyban segíti, hogy a probléma saját nevet, ezáltal az önálló létezés lehetőségét kapja meg. Aminek neve van, az létezik. Azt lehet értelmezni, arról lehet gondolkozni, beszélni, átalakítani, feldolgozni stb. Laci a domináns narratívájának a „rossz lelkiismeret” nevet adta.

A dekonstrukció részeként „rossz lelkiismeret” konkrét hatását kerestük meg az elmúlt évek néhány zürös eseményében. Például bizonyos feladatokat el sem kezdett, mert eleve nem bízott magában. Magától adódott, hogy ezután a munkában történő helytállás mögött lévő belső küzdelmeit (korai felkelés, kevés fizetés megbecsülése stb.) is a „rossz lelkiismeret” és egyéb én-részek közötti egyezkedés keretében értelmezzük.

Külön figyelmet szenteltünk annak, hogy milyen külső erők hatására alakult ki „rossz lelkiismeret”. Ezt elsősorban édesanyjával hozta kapcsolatba. Tágítva a figyelem körét érthetö lett, hogy Anya is kulturálisan meghatározottan viselkedett. Apa elhagyta a feleségét és a gyermekeit, a családi emlékezet ezért apát felelőtlennek minősítette le. Anya egyedül maradt, és a sok generációs protestáns paraszti munkakultúrát és az apai szigort az egzisztenciális bizonytalanság erösítőjén keresztül adta át a gyermekeinek, és követelt tölük. Mindezt a tágabb család és a környezet elismerő tekintetének kíséretében. „Rossz lelkiismeretet” tehát Anya hozta létre társadalmi támogatással. Volt hozzá elég hatalma. De mi 
köze van ehhez Lacinak? Ez az Ö életterve, vagy az anyjáé? Miben azonos és miben más a kettő? Miben kell Anyához lojálisnak lennie és miben teheti meg, hogy ne legyen az?

„Rossz lelkiismeret” dekonstruálása és egy új narratíva rekonstruálása nem válik el egymástól, mert minden felismerés egyúttal az ellentéte felismerését is jelenti (Wilber 2000). Amint egy bizonytalan, elmosódott érzésben elkezdünk tudatosan részeket lehatárolni, azonnal adja magát a létrejött határ másik oldala, ami már az új narratíva konstrukciójába kerül beépítésre.

Így készítette el magának Laci az új narratíváját. Eszerint ő keresi a saját útját. Nehéz folyamat ez, sok megbotlás és felállás története, valamennyire el is maradt vele, de keményen küzd. Erős, most már tapasztalt is, és meg fogja tudni hozni a saját döntéseit. Ez egy nyitott, több alternatíva lehetőségét hordozó narratíva, amelynek Laci nem elszenvedője, hanem az aktivitása szembeötlő.

Fél évvel a terápia vége után Laci Budapesten szükös anyagi viszonyok között él, dolgozik, egyensúlyban van az élete. Havonta jár haza. Édesanyja a megállapodás szerint fizeti a rezsije egy részét, Laci ettől több pénzt nem kér. A saját életéről, a vitatott kérdésekről otthon nem beszél. Anya változatlanul aggódik, de úgy érzi, hogy távolságot tart a fiától. Ha ismét valami bajt csinálna, hagyná, hogy oldja meg saját maga. Békében élnek.

\section{Megbeszélés}

A klienseink mindig több releváns narratíváról számolnak be, és időnként szükség van arra, hogy kiválasszuk, ezekből melyikkel kívánunk először foglalkozni. Esetünkben ez anyánál igényelt megfontolást, Lacinál a választás nyilvánvaló volt. A narratíva kiválasztásának szempontjait az esetleírásban részletesen ismertettem, ezért itt csak egy szempontra, az etikaira kívánok kitérni.

A posztmodern, konstrukcionista alapszemléletü pszichoterápiák lényegéből fakad, hogy a kliensek által konstruált valóságot érvényesnek ismerik el. Sem a társadalom aktuális domináns diskurzusait, sem a terápiás rendszerek, sem pedig a terapeuta konstrukcióit nem helyezik a kliensé fölé. Sőt, a terapeuta és a kliens hangsúlyozottan egyenlő pozícióját hirdetik, illetve bátorítják a klienseket, hogy a domináns diskurzusokkal szemben éljenek kritikával, és találják meg sajátjaikat. A narratív irodalom az etikai kérdések körében többnyire azt hangsúlyozza, hogy a kisebbségekkel, a gyöngébbekkel, a betegekkel szemben a többség, az erősek és a segítők mértéktartóak, ezáltal etikusak legyenek (Kecskeméti 2004). A narratív terapeuták pedig legyenek tudatában, hogy helyzetüknél, tudásuknál fogva az erős oldalon vannak. Bátran támogassák a kisebbségben lévőket. 
Amellett, hogy a felsorolt érveket alapvetően elfogadom, muszáj szóvá tenni, hogy a pszichoterápiás gyakorlat szintjén, ahol egyénekkel, illetve egy-egy családdal foglalkozunk, a domináns diskurzussal szembeni bátor kiállás elve erösen individuális természetü. Tudjuk, hogy az individualizmus-kollektivizmus dimenziójában elfoglalt pozíciónk erősen függ a kultúránktól. A nyugati civilizáció az individualizmus felé lejt. A narratív terápia ezen belül is erősen individualistának számít.

\section{A kiegyensúlyozott gondolkozás érdekében érdemesnek tartom azonban a kollektivizmus értékeire is vetni egy pillantást.}

Azzal a nyilvánvaló ténnyel, hogy a hagyományok, az erkölcs, a vallás, vagy általában a kultúra milyen szükséges társadalomszervező funkciót tölt be szükségtelen foglalkozni. Ennek értékét még akkor sem vitathatjuk el, ha az egyénre nézve következményeik kétségtelenül gyakran represszívek. A konkrét terápiás gyakorlatban azonban nem kerülhetjük el a dilemmát. Esetünkben anya elkeseredett, és erkölcsileg leírta a fiát, mert az léhán élt. Lacinak pedig lelkifurdalása volt emiatt, és önmaga számára is kétes hitellel mentegetőzött. A léha életet a társadalom elítéli. Mit tegyen a terapeuta? Beáll a társadalmi kórusba, vagy relativizálni fogja a léhaságot, és segít a lelkifurdalást dekonstruálni? Mikor enyhítse a terapeuta a lelkifurdalást, és mikor nem? Ezekre a kérdésekre adott válaszok nyilván a terapeuta értékrendjéről és arról szólnak, hogy kívánja-e ezeket képviselni a terápiás térben. A bemutatott esetben mindenképpen a közvélekedés mellé kellett állnom. Részben könnyü volt, mert saját véleményemhez is ez állt közel, másrészt ellenkező esetben mindkét családtag előtt csorbult volna a hitelességem. A „bün” elismerésével viszont megnyílt az út a megbocsátás és a jóvátétel előtt. Az a tény, hogy a családtagok véleményét elfogadva a „léhaság” ellen foglaltam állást egyúttal lehetővé tette számomra azt is, hogy az ebböl levont túlzó következtetéseket (Laci az életét véglegesen elrontotta) hitelesen megkérdőjelezzem.

A jelen esettanulmány egyik legfontosabb kérdése kétségtelenül az, hogy miért volt eredménytelen a rendszerszemléletü terápia, mit nyújtott ehhez viszonyítva a narratív terápia, és mi a kapcsolat a két elméleti konstrukció között. A kérdés tárgyalását illő szerénységgel kezdem, elég nagy teret engedve az elméletek lényegéhez nem tartozó szubjektív tényezőnek.

A két módszer összehasonlításának jó keretét adja Ken Wilber Integrál elméletének a holonokat 4 irányból leíró modellje (Wilber 2007). A holon fogalmát elöször Koestler használta (Koestler 1967), jelentése részegész. Azaz egy olyan kategória, mely részekből áll, de önmaga is része egy nagyobb egységnek. A továbbiakban tekintsük a tanulmányozandó holonnak anya és Laci két fós családját! 
Az Integrál elmélet szerint anya és Laci történetéről alapvetően két oldalról tudunk információt szerezni. Az egyik egy külső megfigyelő objektív nézőpontja, a másik pedig Anya és Laci szubjektív világának értelmezése. Mind a két oldalt további két részre lehet felosztani aszerint, hogy a figyelmünket csak a megfigyelt személyekre korlátozzuk, vagy ehelyett a megfigyelt személy környezetével való kölcsönhatásait, a kollektív viszonyokat vesszük figyelembe. Hagyományosan ezt a szemléletet a síkot négy negyedre osztó mátrixszal illusztráljuk (1. ábra), ahol a bal oldali mezők a szubjektív, a jobb oldaliak az objektív, a felsők az egyéni, az alsók a kollektív minőséget jelentik.

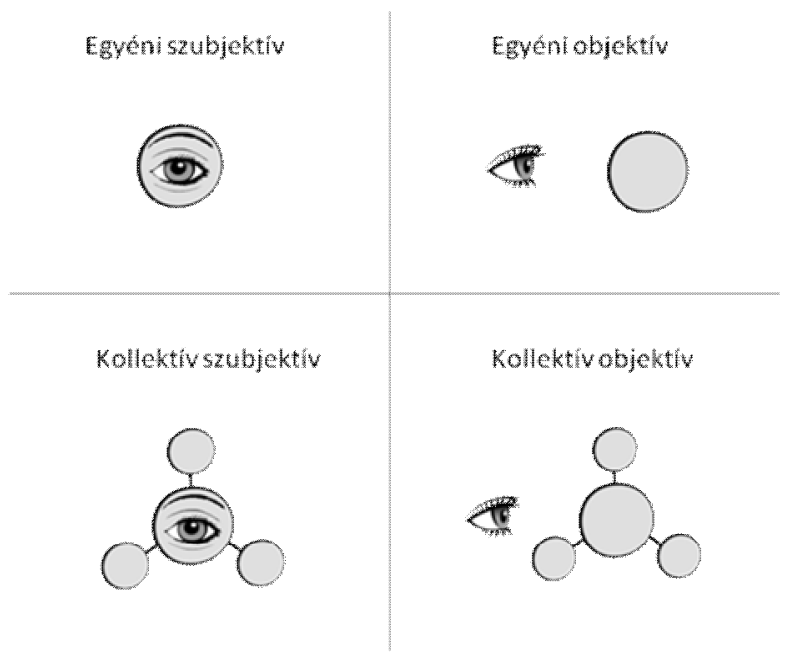

1 ábra.

A valóság négy oldala.

Négy egyenrangú megközelítésről van szó, minden megközelítés ugyanazokról a személyekről szól, más-más irányból. Az információszerzés módszerei azonban lényegesen különböznek.

A jobb oldal az empirista modern tudomány eszközeivel dolgozik. A mi pszichoterápiás esetünkben természetesen nem mikroszkópra vagy kérdőívek statisztikai feldolgozására gondolunk, hanem a jobb felső negyedbe tartozna például a tünetek leírásán alapuló BNO diagnózis. A kollektív, objektív (jobb oldali alsó negyed) területéhez tartozik a rendszerszemlélet. Az információk jelentős része természetesen a rendszerszemléletü terápiában is a kliensek elmondásából származik. A rendszer megismeréséhez azonban viszonylag objektív információk révén el lehet jutni, és maguk a megismert tények sem szorulnak bonyolult értelmezésre. Például a határok, a hierarchia, a szabályok, az 
életciklusváltás stb. mind-mind objektív, „,tudományos”, érzelem nélküli kategóriák. Egyértelműen definiált fogalmak, általában ugyanazt érti alatta mindenki. A mátrix bal oldalának, azaz Anya és Laci szubjektuma felőli megismerésnek viszont komoly módszertani nehézséggel kell megküzdenie. Valakinek a gondolatait, vágyait, szorongásait csak akkor ismerhetjük meg, ha ő közli velünk, és ezt helyesen értelmezzük. Ez a folyamat sok szürőn keresztül valósul meg, részleteit a hermeneutika tanulmányozza. (Bókay 2006) Az erőfeszítésért cserébe viszont a megismerő a másik személy szubjektumáról szerez tudást.

A narratív terápia szemléletét átgondolva azt látjuk, hogy a kliensek egyéni és kollektív szubjektív világában mozgunk. Maga a szociális konstruktivizmus lényege az objektív valóság helyett a szubjektív konstrukciók hangsúlyozása. Ebben a dimenzióban a lényegéből fakadó természetességgel dolgozunk Anya érzésével, hogy "Lacit ő szülte, és egy szülőnek mindig oda kell állnia a gyermeke mellé, akkor is, ha belepusztul". Amikor arról beszéltünk, hogy Laci „rossz lelkiismerete” nagyrészt anya és a helyi társadalom közvélekedése hatására alakult ki, akkor a mátrix bal alsó, azaz kollektív szubjektív mezőjében mozogtunk. A narratív terápia fókusza tehát a kliens érzésein volt.

Visszatérve a rendszerszemléletre, ebben a keretben a különbség még inkább látható. A rendszerszemléletű gondolkodásnál valóban nincs szó arról a nagyon bonyolult, a kliens és a terapeuta szubjektuma által egyaránt jelentéssel felruházott értelmezve megismerő folyamatról, mint a bal oldali negyedek esetében. Mindez azt is jelenti, hogy a szoros értelemben vett rendszerszemléletü gondolkodás mostohán viszonyul az érzelmekhez. A rendszerszemléletű terápiás térben természetesen ugyancsak nagyon intenzív érzelmeket élünk át, sírunk, nevetünk, katarzisban van részünk: de ez nem a tisztán vett rendszerszemlélet hozadéka, ez már attól több. Virginia Satir például ismert élményközpontú terápiájában a rendszerszemléletet Gestalttal és énpszichológiával ötvözte (Prochaska és Norcross 2011).

A rendszerszemléletü terápiák történetében fontos fejlemény, hogy Boscolo és Cecchin új poszt-milánói szemlélete szerint a családot és a terapeutákat egységes rendszernek tekintik, mivel a terapeuták aktív jelenlétükkel a családrendszernek elkerülhetetlenül részévé válnak. Miután a megfigyelt és a megfigyelő korábbi különállása ezáltal megszünik, egy lépés csak, és a terapeuták a szakértő mindent tudó pozícióját feladva a családdal közös konstrukciók alkotásában határozzák meg a terápia lényegét (Boscolo, Checcin, Hoffman, Penn 1987). Mindez a rendszerszemléletü és a konstruktivista terápiák ötvöződését, a szubjektív és objektív megértés integrálását jelenti.

A bemutatott esetben a modernista, rendszerszemléletü terápia elakadását az anya általam akkor megoldhatatlannak bizonyult érzelmi ellenállásával hoztam kapcsolatba. Ezt az elakadást egy a szubjektumra erősebben fókuszáló szemléletváltással sikerült megoldanom. A posztmodern, konstruktivista terápiás mód- 
szer esetünkben jobban kiszolgálta a hagyományait vesztett, olykor kaotikus viszonyok között élő család igényeit.

\section{Irodalomjegyzék:}

1. Berg, Insoo Kim (991): Konzultáció sokproblémás családokkal. Animula, Budapest.

2. Boscolo, Luigi; Checcin, Gianfranco; Hoffman Lynn; Pen, Peggy (1987): A milánói módszer. Animula, Budapest.

3. Bókay Antal (2006): Bevezetés az irodalomtudományba. Osiris, Budapest.

4. Goldenberg, Herbert és Goldenberg, Iren (2008): Áttekintés a családról Animula, Budapest.

5. Kecskeméti Molnár Mária (2004): Narratív terápia. Bemutató és ajánlás ÚjZélandból. Pszichoterápia 13. 6. 366-376.

6. Koestler, Arthur (1967): Szellem a gépben. (Ford. Makovecz Benjamin), Európa Kiadó, Budapest.

7. László Ervin (2001): A rendszerelmélet távlatai. Magyar Könyvklub, Budapest.

8. László János (2005): Történetek tudománya Új Mandátum Könyvkiadó, Budapest.

9. László János (2008): Narratív pszichológia. Pszichológia 28.4 301-317.

10. Mahoney, Michael J. (2003): Constructive Psychotherapy: Theory and Practice The Guilford Press, New York.

11. Minuchin, S. (1974): Családok és családterápia Animula, Budapest.

12. Prochaska, James O. és Norcross John. C. (2011): A pszichoterápia rendszerei. Animula, Budapest.

13. White, Michael és Epston, David (1990): Narrative Means to Therapeutic Ends. Norton \& Company, London.

14. Wilber, Ken (2000): Határok nélkül. Édesvíz Kiadó, Budapest.

15. Wilber, Ken (2009): A Működő Szellem rövid története Ursus Libris, Budapest.

16. Wilber, Ken (2007): Integrál szemlélet. Ursus Libris, Budapest.

dr. Bojti István: Pszichoterapeauta, belgyógyász orvos 


\section{UNIVERSITY \\ OF DEBRECEN}

FACULTY OF

HEALTH

NYÍREGYHÁZA

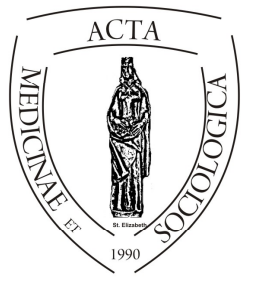

ACTA

MedSoc

VOLUME 5.

2014

\title{
Civil szervezetek, civil engagement, civil érintettség
}

\author{
Szabados György \\ Debreceni Egyetem, Vezetés és Szervezéstudományi Intézet, \\ Vezetéstudományi Tanszék
}

\begin{abstract}
Some literatures mention a civic organization and activity boom in Hungary after the change of the former regime. Although there was an increase in the number of the classic civic organizations, lately this trend has stopped, and we may also expect a decrease in their number owing to the new regulations, requirement of the civic act.

The importance of the sector is usually approached by the figures of the Statistical Office, and we may also exaggerate it regarding economic capacity and human resources, volunteers, but a deep look may reveal a different, diverse picture. It is really hard to estimate the background, effect, movements behind the civic sector, international literatures discuss this issue in the framework of the civic engagement. In a private examination I may also contribute to the better approach of the importance of the civic sector, by studying and measuring the „civic affectedness" complex indicator. This examination revealed a medium or smaller level of affectedness among inhabitants of a dedicated settlement.
\end{abstract}

Keywords: non-profit, NGOs, involvement, Sárrét. 


\section{Bevezető}

Érdekes és fontos lenne tudni, hogy vajon mit is tud ma a társadalom a civil szervezetekről. Amennyiben ma civil szervezetekről beszélünk, az embereknek erről a szervezeti típusról nem mindig ugyanaz jut eszébe. Ha felvetődik a nonprofit elnevezés, valószínúleg az már inkább sokatmondó fogalom, noha a két terminus nem teljesen ugyanaz. Geszti (é.n.: 2) szerint „Már önmagában a civil szervezet megjelölés sem egyértelmü, hiszen minden országban más-más fogalom társul hozzá. Szokás harmadik szektorról is beszélni, megkülönböztetve ezáltal az állami és üzleti szférától. Legmegfoghatóbb a nonprofit kategória".

A kormányváltás eredményeként a politika a civil szervezetek szabályozási környezetének gyökeres megújulását is célul tüzte ki. 2011. év végén jelent meg az új civil törvény (és a kapcsolódó további szabályozások ${ }^{1}$ ), mely a szokásos eljárási gyakorlathoz képest több új követelményt is megfogalmazott, mint például a civil szervezetek fogalma, új civil szervezeti forma bevezetése - a civil társaság megjelenése, a közhasznúság új követelményei, megfelelőség, könyvvezetési követelmények, kötelező átalakulás, stb.

A hétköznapi statisztikai adatok a szervezetek oldaláról közelítik meg ezt a kérdést. A KSH nonprofit szervezetekkel kapcsolatos kiadványa a magyarországi civil szervezetek viszonyairól is rövid, informatív áttekintést $\mathrm{ad}^{2}$. 2011-ben mintegy 65,5 ezer nonprofit szervezet müködött Magyarországon, egyharmaduk, 23,2 ezer alapítványi formában, 42,3 ezer társas nonprofit szervezetként. A nonprofit szervezetek döntő többsége tehát civil szervezet. Ha ezt a számot a KSH 2010-es, vállalkozásokra vonatkozó adataihoz hasonlítjuk ${ }^{3}$, így nagyjából 10 vállalkozásra jut 1 nonprofit szervezet. A civil szektorban az általános KSH adatatok igazából egy viszonylag jó képet festenek a civil szektorról, melynek részletei már igen árnyaltak. A bevételek eloszlása igen egyenlötlen, a szektor meglehetősen polarizált ${ }^{4}$. A számított foglalkoztatottak mintegy negyede jutott az egyesületekre és alapítványokra. A gazdasági kapacitás mellett a humán eröforrás ellátást szokás a szféra jelentőségével kapcsolatosan megemlíteni. Noha a nonprofit szektorban a foglalkoztatottak száma nem elenyésző, annak csupán töredéke jut a civil szervezetekre. Összességében a klasszikus civil szervezetek-

\footnotetext{
${ }^{1}$ 2011.évi CLXXV. civil törvény, 2011.évi CVXXXI.törvény, 2011.évi 350. kormányrendelet, 2013.évi V.tv).

${ }^{2} \mathrm{http}: / /$ www.ksh.hu/docs/hun/xftp/stattukor/nonprofit/nonprofit11.pdf

${ }^{3} \mathrm{http}: / /$ www.ksh.hu/docs/hun/xstadat/xstadat_eves/i_qpg005a.html

${ }^{4}$ Az 5 millió Ft alatti bevétellel rendelkezők aránya 80,9\%, az 50 millió Ft feletti bevétellel rendelkező 4,3\%-nyi szervezet a szféra bevételeinek 83,8\%-val rendelkezik. http://www.ksh.hu/docs/hun/xstadat/xstadat_eves/i_qpg006.html
} 
nél nagyjából 52000 fő fóállású foglalkoztatottnak megfelelő humán kapacitásról beszélhetünk (foglalkoztatott és önkéntes együtt), ami az alig több, mint 57 000 szervezetet tekintve nem igazán jelentős, szervezetenként tehát alig éri el az egy foót a munkakapacitás és ebben benne van az önkéntes munka nagysága is. A leegyszerüsítés lehet túlzó, ugyanakkor a szektor polarizáltságát tekintve a kép még ennél is árnyaltabb lehet. Korábbi vizsgálatok is megerősítették a szektor megosztottságát (Murányi-Szerepi, 2005: 54).

Amennyiben arra gondolunk, hogy a nagyjából 60 ezer civil szervezet jelentősége mekkora, (rendelkezésre álló adataink alapján) ki kellene merüljön abban, hogy hányan vannak, mennyi a bevétele-kiadása, gazdasági kapacitása és menynyi tag, önkéntes dolgozik a szervezeti célok megvalósítása érdekében. Csakhogy a civil szervezetek javarésze nem pusztán a szervezeti tagok érdekeit kívánja támogatni, hanem az oly sokszor említett társadalmi felelősségvállalás aktív szereplői is, tevékenységük révén tisztább a környezetünk, többen és jobban tanulhatunk, egészségesebben élhetünk vagy épp jobb nemzetközi kapcsolatokra tehetünk szert. Tehát a valójában konkrétan leírható szervezetek egy nagyobb társadalmi bázis érdekei végett müködnek, a társadalom, az ország életkörülményeinek, létfeltételeinek javításán dolgoznak. Nehéz találni olyan konkrét becslést arra vonatkozóan, hogy valójában mekkora az a társadalmi bázis, melyet tevékenységük érint és arra sem, hogy az milyen területeken jelentkezik. A civil szervezetek életben maradása, és jövője attól is függ, képesek-e az ügyfelek által elvárt szolgáltatást magas színvonalon, kiváló minőségben teljesíteni (Oláh, 2008).

\section{„Civic engagement”}

A nemzetközi irodalmakban (pl. Brint-Levy 1999: 164), Cnaan-Milofsky 2007: 75) tárgyalják a „,civic engagament ${ }^{5,}$ kérdéskörét, ez alapvetően a civil mozgalmakhoz, szervezetekhez kötődő állampolgári aktivitással kapcsolatos. A „,civic engagement" azt jelenti, hogy az állampolgárok együtt dolgoznak egy közös jóért és a társadalmi tőke egy viszonos alapú kikényszeríthető bizalom mintáin nyugvó kapcsolatrendszer, mely lehetővé teszi az emberek és intézmények olyan erőforrásokhoz jutnak, mint szociális szolgáltatások, önkéntesek és támogatások. A civil az állampolgári tevékenységekkel kapcsolatos fogalom, az részvétel pedig aktív közremüködést jelent. A civil részvétel arra vonatkozik, hogy az állampolgárok civil társadalmi intézményekben, pl. nonprofit szervezetekben vesznek részt azért, hogy általános társadalmi célokat szolgáljanak. A részvétel a

\footnotetext{
${ }^{5}$ Civil részvételként használom a kifejezést.
} 
társadalom alapú szervezetekben olyan mechanizmus, mely a közjót szolgálja (Cnaan-Milofsky 2007:75). Annak ellenére, hogy igen megnőtt a rendszerváltás óta a civil szervezetek száma, a tényleges részvételi arány az EU átlaghoz képest alacsony. Cartwright et al. (2008: 3) szerint itthon csak a népesség 21\%-a tagja valamiféle szervezetnek. Az önkéntes munkában való részvételt tekintve- egy 2006-os felmérés alapján ${ }^{6}$ az állampolgárok mindössze $17 \%$-a vesz részt, vagy csinált önkéntes munkát (mi az EU átlag végén vagyunk). Legjellemzőbb a sport vagy szabadidős tevékenységekben való részvétel. A munka azt sugallja, hogy a részvétel itt alapvetően foglalkoztatottakat és önkénteseket jelent. A részvétel indikátoraként említik még az adományok felajánlását (pl. véradás is), más érdekében történő kockázatos helyzetekbe történő beavatkozást, a családokkal, barátokkal történő kapcsolattartás rendszerességét. Úgy tünik, hogy a végzettségek, státuszok szintjének csökkenésével a civil részvétel is csökken (legmagasabb menedzserek között). Bácsné (2012) vezetőkkel végzett idővizsgálatai is alátámasztják e réteg érzékenységét a társadalmi tőke környezeti változásokban betöltött szerepével összefüggésben). A civil részvétel körébe tehát számos indikátor beletartozik (önkéntesek, foglalkoztatottak, kapcsolatok, stb.) de vannak bizonyos, eddig részleteiben nem teljesen lefedett további kérdések is.

Érdekes lenne feltenni a kérdést, hogy vajon legalább ennyire fontos az is, hogy mennyi jut el belőle az ország számára? Mit jelent a társadalomnak, a gazdaságnak és elsősorban az egyéneknek a civil szervezeti szféra? A civil szervezetek ugyanis nem feltétlenül és nem mindig a tagok, az önkéntesek, a foglalkoztatottak érdekeit szolgálják, hanem egy további, mögöttes informális közösség által explicit vagy implicit módon megfogalmazott célokat is. Épp ezért lényeges, hogy mennyit és mit tud róluk környezetük, és vajon a környezet maga is felismeri-e azt, hogy saját, sokszor egyénre lebontott céljaik harmonizálnak a civil szervezetek által megfogalmazottakkal vagy épp nem.

\section{Civil érintettség}

A téma továbbvisz minket egy általam definiált olyan területre, melyet egy korábbi kutatás tanulmányozása során adaptáltam. Kovách $(2005: 25)^{7}$ a mezőgazdaság rendszerváltás utáni jelentőségét vizsgálva úgy vélte, hogy noha a foglal-

\footnotetext{
${ }^{6} \mathrm{http}: / /$ ec.europa.eu/public_opinion/archives/ebs/ebs_273_en.pdf

${ }^{7}$ A kutatás részleteiről még: Kovách I. (2012): A vidék az ezredfordulón. A jelenkori magyar vidéki társadalom szerkezeti és hatalmi változásai. Arumentum Kiadó-MTA Társadalomtudományi Kutatóközpont (Szociológiai Intézet), Budapest.42-46.old.al.
} 
koztatottak száma viszonylag alacsony szintre esett napjainkra, a társadalom többsége valamilyen módon, bár különböző mértékben mégis agrárérintett, azaz van kapcsolata a mezőgazdasággal. Kovách vizsgálatai rámutattak arra, hogy az agrárérintettség többféleképp megragadható (pl. úgy is, hogy valaki a szektorban foglalkoztatott, de úgy is, hogy termőföldje van, vagy épp mezőgazdasági iskolázottsága van, vagy piaci vagy akár saját értékesítésre állítanak elő mezőgazdasági terméket. A különböző érintettségi kategóriák vizsgálata révén a mezőgazdaság helyzete nem jelentéktelen: „2005-ben így a felnőtt lakosság 51,6 százaléka volt közvetlenül agrárérintett"

A civil szervezeteket tekintve világos, hogy például egy településen müködő civil szervezet, néhány 10 fő taggal, önkéntessel vagy jobb esetben foglalkoztatottal és bizonyos bevétellel-kiadással jelentőségében nem csupán ennyit jelent, nem egyszerüsíthető le ennyire jelentőségük, illetve az általuk kifejtett hatás ebben nem merül ki. Müködtethetnek teleházat, biztosíthatnak ingyenes szolgáltatásokat, rendezhetnek falunapokat vagy épp nyírhatnak parlagfüvet vagy utcát, járdát takaríthatnak, melyek nem elsősorban externáliák, ugyanis a szervezetek céljai épp ezzel vannak összefüggésben, erre irányulnak. Az utóbbi 10 év jelensége a civil szervezetek és az állami hivatalok összefogása, amellyel a munkaerőpiacon hátrányt szenvedőket támogatják. A segítség ilyen formája az európai országokban hosszú évek jellemző civil feladat, amely a 2000-es évek eleje óta különböző pályázatok útján vált hazánkban lehetővé (Móré 2012). A civil érintettség, az előbb említett vizsgálathoz hasonlóan, hüebb, valósabb képet adhat a civil szervezetek hatásáról, vagy épp kiegészíti, újraformálja gondolkodásunkat a civil szervezetek müködésével kapcsolatosan.

A fogalom maga összetett, és több oldala van. A civil érintettség általánosságban azt jelenti, hogy milyen összefüggés jellemzi a civil szervezeti szférát és az embereket - milyen a civil szervezetek hatása az emberekre. Részleteiben azt jelenti, hogy a civil szféra a társadalom elemi egységeinek életét tekintve mit jelent a civil szervezet, milyen a civil szervezetekkel kapcsolatos társadalmi intenzitás, milyen összefüggés van a civil szervezetek és a társadalom, az élet javítása között, milyen az érintettség mélysége, milyen területeken érintett, milyen erősségü a civil szervezetek hatása. Az említett változók egy összetett fogalom különböző aspektusait veszik górcső alá, és így a sokszor különböző helyről származó információk és különböző megközelítések mellett néhány adattal jellemzi a civil szervezetek és a társadalom viszonyát. Az egyik ilyen változó, az emberek munkával kapcsolatos viszonyainak és a megélhetésének, anyagi boldogulásának kérdése például nem jelenik meg határozottan a KSH nomenklatúrában. Ibrahim-Hulme (2010:2) szerint egyre jelentősebb a figyelem a szegénység és nyomor csökkentése irányában, és felmerül a kérdés, hogy a civilek miért feministák vagy épp környezetvédők, és miért nem szegénységcsökkentők?A civileknek ugyanis kulcszerepe kellene lennie az ilyen ügyek pártolásában, az 
ilyen ügyekben való részvételben és a fenntartható szegénységcsökkentés elősegítésében.

Maga az érintettség alapvetően két oldalról is megközelíthető. Elsőként a hétköznapi embereknek, a lakosoknak van álláspontjuk, véleményük, így attitüdjük megismerhető a civil szervezetekkel kapcsolatosan. Egy nagymintás reprezentatív felmérés ennek részleteiről többet elárulhatna.

Létezik emellett vonatkozó véleménye maguknak a civil szervezeteknek is, látják, megbecsülhetik, tapasztalhatják, hogy milyen területekre terjed ki müködésük ${ }^{8}$, hány emberre vonatkozóan, milyen mélységben.

A cikk lehetőséget ad arra, hogy egy nem régi kutatás eredményeit a fentiekkel kapcsolatosan bemutathassam. A kutatások lényegi része egy választott településen a civil érintettség részleteinek bemutatása. A település választásának indokai között szerepel annak nagysága, periférikus elhelyezkedése, a mintavétel korlátai, valamint a civil szervezetek csekély száma is.

A vizsgált település a Sárréti Kistérség egyik legkisebb települése. HajdúBihar megyében, meglátásom szerint igen periférikus területen fekszik, viszonylag távol még a kisebb városoktól is. A település legnagyobb lélekszámát az 1800-as évek közepén regisztrálták ( 800 fö) ez azóta sajnos folyamatosan csökken, a lakosság lélekszáma a statisztika szerint jelenleg alig több, mint 202 fö (informális információk szerint 200 alatt van). A települést végigjárva az igazi falusi jellegủ kistelepülés. Egy ilyen kistelepülésen szinte mindenki ismeri egymást, az emberi viszonyok meghittebbek, közvetlenebbek. Utasi (2012: 8) szerint a lokális közösségi identitás fontos kritériuma és mérőszáma a falu közösségéhez tartozás érzése, a kötődés, és a civil szervezetek ezeknek a közösségszerveződéseknek a színterei. A településen ugyanakkor mindössze 2 civil szervezet müködik, egy egyesület és egy alapítvány, ahol a tagok és önkéntesek száma a kettő esetében is jó, ha a 15 föt eléri. Valójában a periferikus elhelyezkedés, a kormegoszlás miatt feltételezhető, hogy a civil szervezetekkel kapcsolatos véleményt ezzel a két szervezettel kapcsolatosan szükítik le a válaszadók. Ritka, és igencsak alkalmi jellegü, ha más településen müködő civil szervezetek munkájába egy-két helyi bekapcsolódik.

A vizsgálat módszere tekintetében a reprezentativitást biztosító K-szempontú szisztematikus mintavétellel dolgoztunk ${ }^{9}$. A vizsgálat időpontjában rendelkezés-

\footnotetext{
${ }^{8}$ Az alapító okiratban vagy alapszabályban megfogalmazottakkal ellentétben-hasonlóan a vállalkozásokhoz-nem mindegyik megfogalmazott tevékenységgel foglalkoznak, egy jelentős részük inkább csupán néhány területen aktív.

${ }^{9}$ A kutatás során egy kutatással két párhuzamos vizsgálatot végeztünk: jómagam általános érintettségi, Pierog Anita kolléganőm pedig gazdasági érintettséggel kapcsolatosan gyüjtött adatokat. A kutatás a Balassi Ferenc Kulturális és Közösségteremtő Egyesület
} 
re állt a helyi lakossági lista, mely során a 202-fős lakosság nagyjából felét, 100 föt sikerült lekérdezni a civil érintettség kérdéskörével kapcsolatosan. A felmérést felkészített kérdezőbiztosokkal végeztettük el, a megbízhatóságot külön adatok bekérésével garantáltuk. A teljes sokaságon belül a megbízhatósági intervalluma 95\%-os valószínüségi szinten +/- 6.98. A mintavétel véletlen, és az említett megbízhatóság mellett viszonylag pontos becslést tesz lehetővé, az egész településre vonatkozóan. A teljes vizsgálati eredményekből csupán néhány részletet ragadnék ki.

A kérdőíves felmérés mintájának interjúazonosítóit tekintve elmondható, hogy közel azonos arányban voltak férfi és nő válaszadóim, megkérdezettek 53\%-a férfi, 47\%-a nő. Kormegoszlását tekintve a minta többségében föleg középkorú illetve annál idősebb, a 60 év felettiek aránya egy harmad, az 50 felettieket tekintve arányuk majd 50\%, tehát úgy gondolom, hogy korfát tekintve idősödő településről van szó. Az iskolai végzettségét tekintve a helyzet nem minősíthető előnyösnek, a felsőfokú végzettségüek aránya igen alacsony (3\%), a maximum 8 általánossal és annál alacsonyabb végzettségüek aránya több, mint $50 \%$, illetve közel 40\% a középfokú végzettségüek aránya. A megkérdezettek 34\%-a foglalkoztatott, a munkanélküliek aránya 14\%, az aktívak aránya összességében tehát $48 \%$, ez a megyei és az országos adatoknál valamelyest rosszabb. Az inaktívak aránya 16\%, a nem munkaképes korúak aránya $36 \%$.

A survey első szakmai kérdése arra vonatkozott, hogy milyen a megkérdezettek alapvető ismerete a civil szervezetekkel kapcsolatosan. Az eredményeim alapján úgy tünik, hogy a megkérdezettek csupán harmada tudja hogy mit is jelent egy civil szervezet. A megkérdezettek közel felének $(43,4 \%)$ ismerete a civil szervezetekröl közepes, inkább homályosabb (vannak elképzeléseik). Emellett a minta további majd negyede $(23,2 \%)$ nem igazán tudja, mi is a civil szervezet. Úgy tűnik, ez az ismeret némileg végzettség függő, mivel valamennyi felsőfokú végzettségü tisztában van vele, a középfokú és alapfokú végzettségüek ismerete már összességében inkább homályos, a képesítés nélküliek többsége nem tudja, hogy mi a civil szervezet. Némileg korfüggő is, mivel a fiatalabb korosztály inkább, az idősebbeknek, föként a 60 év felettieknek nem sokat mond a civil szervezet kifejezés.

Érdekesnek tünik azt vizsgálni, hogy a civil szervezetek képe a lakosságot tekintve mennyire kapcsolódik össze valamiféle pozitívummal, azaz mennyiben függ össze a helyiek véleménye szerint a társadalom, az élet javítása a civil szervezetekkel. Az eredmények szerint a lakosság ebben a tekintetben inkább bizonytalan (1.ábra).

„Civil érintettség módszertana és civil érintettségi vizsgálatok” szakmai NEA pályázat keretében valósult meg. 


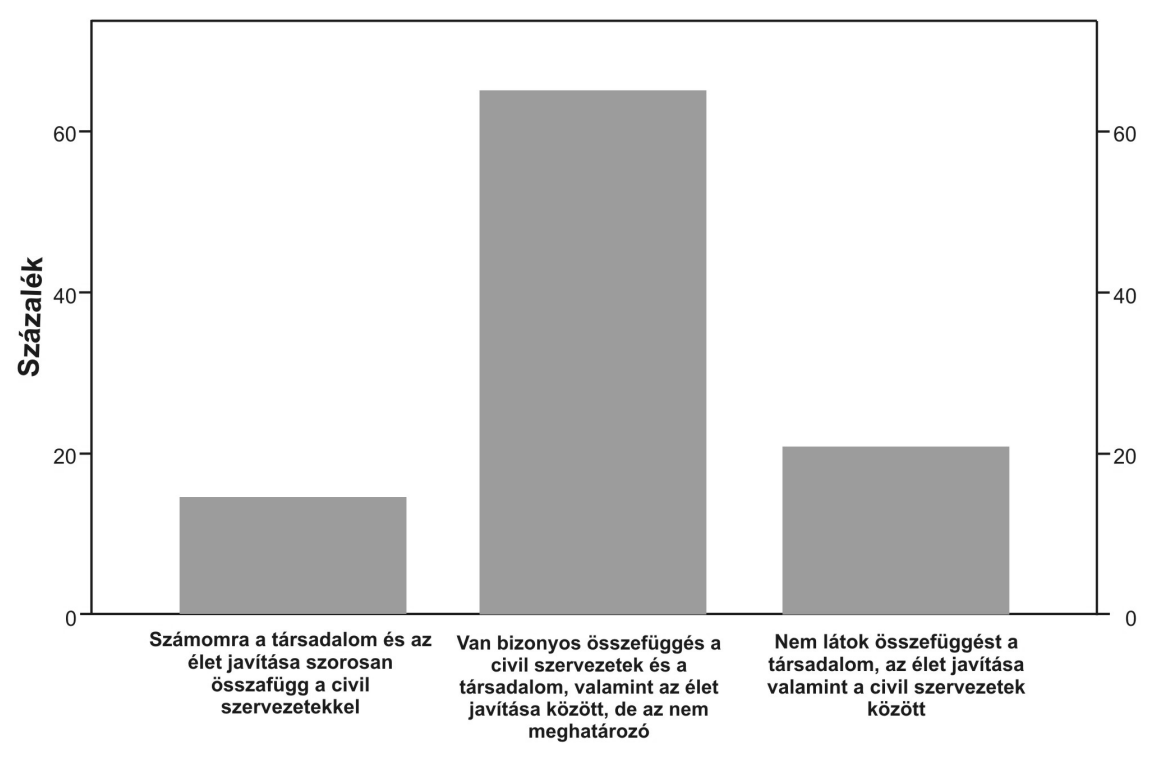

1. ábra: Az vizsgált minta megítélése a civil szervezetek pozitív hatásáról.

Forrás: Saját vizsgálatok, 2013.

A lakosság többségének véleménye arra utal, hogy a többség föként bizonytalan (64,9\%) vagy inkább elutasító azzal kapcsolatosan, hogy a civil szervezetek müködése a társadalom és az élet javítását szolgálná. A válaszadók csupán 14\% gondolta úgy, hogy a civil szervezetek számukra egyet jelentenek az élet javításával. Az eredményt úgy értékelem, hogy a helyzet ebben a tekintetben kedvezőtlen, a helyi civil szervezet hatása nem elsősorban pozitív, sőt többségében inkább bizonytalan és kisebb részben elutasító, tehát a társadalom és élet javításával kapcsolatos érintettség igen gyenge. Korosztály tekintve elsősorban a fiatalabb korosztály ítélete pozitívabb, egészen 50 éves korig, az 51-60 éves korosztály inkább elutasító, az ennél idősebbek pedig inkább bizonytalanok. A végzettségek tekintetében a középfokú végzettségüek inkább bizonytalanok, az ennél alacsonyabb végzettségüek inkább bizonytalanok és elutasítóbbak, a magasabb végzettségüek elsősorban elfogadóbbak. Az inaktívak, nem munkaképes korúak és munkanélküliek inkább bizonytalanok vagy elutasítóak, és a foglalkoztatottak elsősorban bizonytalanok.

A civil érintettség mérhetőségének tekintetében több kategória definiálható. Nyilván ez a kategórialista nem feltétlenül végleges, további szakértői munka és a tapasztalat ezt tovább bővítheti, módosíthatja. 
$>$ A foglalkoztatott és önkéntesi tevékenység erős érintettséget jelent.

$>$ Közepesen érintett az, aki például részt vesz a programjaikban vagy részesül juttatásaikban.

> Gyengén érintett az, aki föként teoretikusan foglalkozik a témával, érdekli, olvas róla, vagy épp szimpatizál, de nem tesz egyebet.

$>$ Az utolsó két kategória összevonható, nem érinti, de tudja miröl van szó vagy egyátalán nincs információja, így mindkettő alapvetően passzív az érintettség szempontjából.

A település lakosságának érintettségének részleteit a 2 . ábra mutatja be:

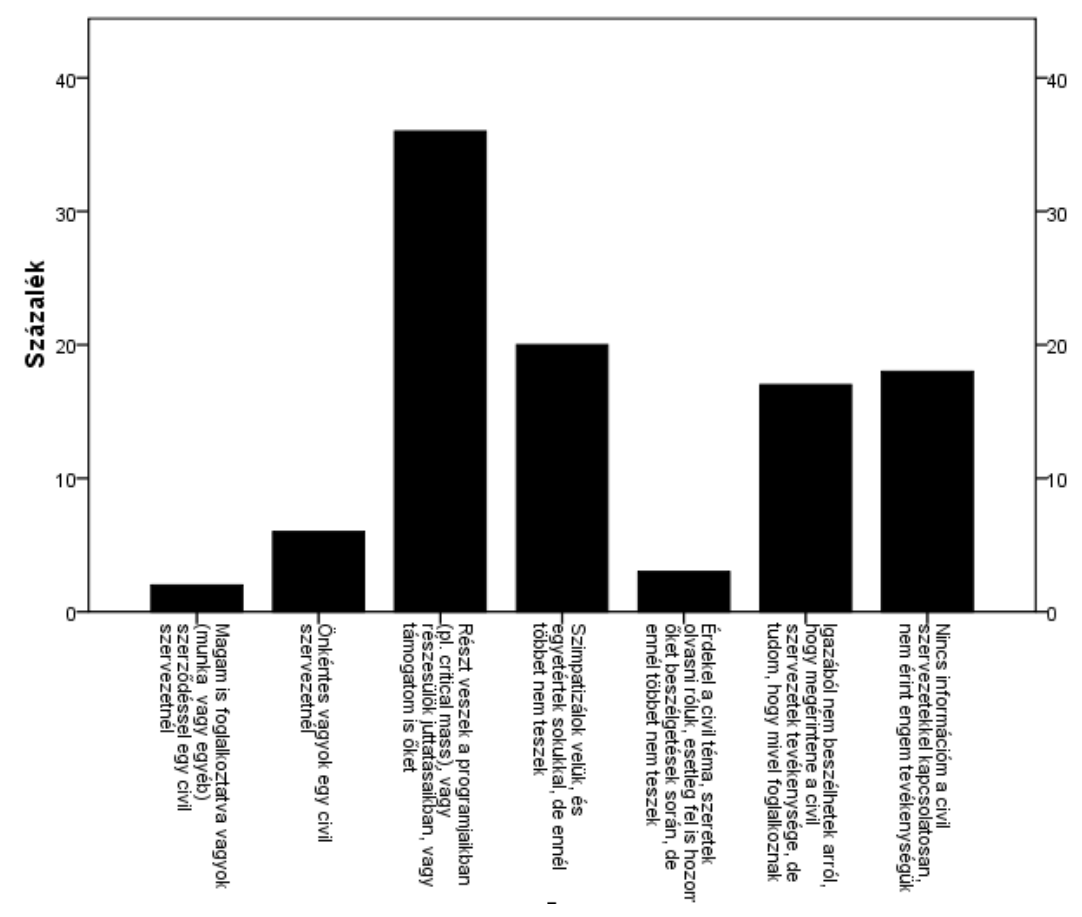

2. ábra: Az vizsgált minta civil érintettségi mélységének megoszlása.

Forrás: Saját vizsgálatok, 2013.

$\mathrm{Az}$ eredmények azt mutatják, hogy a válaszadók megoszlását tekintve $8 \%$ arányban számoltak be erős érintettségről, két válaszadó érintettsége igen erős, 6\%-ban ennél valamelyest gyengébb. A válaszadók érintettsége többségében közepes, 36\% részt vesznek programjaikban vagy részesül juttatásaikban. Egy igen jelentős arány, 20\% szimpatizál velük, és egy igen kis arány $(3 \%)$ fỏ foglalkozik velük elsősorban teoretikusan, de ennél többet ők nem tesznek. A minta 
egy jelentős részét nem érinti a civilek tevékenysége, $17 \%$ tudja, hogy mivel foglalkoznak, de nem érintettek, és $18 \%$ biztos abban, hogy nem érintett, és nincs is információja a civil szervezetek tevékenységével kapcsolatosan. Az összevont eredmények alapján azt mondhatom, hogy a civil érintettség tekintetében a teljes lakosság

$>7,8 \%$-a erösen érintett

$>35,2 \%$ közepesen érintett

$>22,5 \%$ gyengén érintett

$>34,3$ nem érintett.

Az érintettségi görbe tehát nem szimmetrikus, a település lakossága inkább közepesen vagy ennél gyengébben érintett. Az alacsony érintettség vélhetően több dologgal is összefügg, így a korral és feltehetőleg a végzettséggel sőt a foglalkoztatottsággal is.

A civil szervezetek tevékenységei-alapító okiratukban vagy alapszabályukban megfogalmazottak alapján- sokszor szerteágazóak, sokuk egyszerre több célt, és ehhez több tevékenységet is megfogalmaz. Ugyanakkor az már más kérdés, hogy a megfogalmazott célokhoz kapcsolódó tevékenységek mennyiben jutnak el az emberekhez. Ezért érdemes azt is vizsgálni, hogy a civil szervezetek tevékenysége milyen területeken érinti a település lakóit. Az eredményeket a 3. ábra mutatja be.

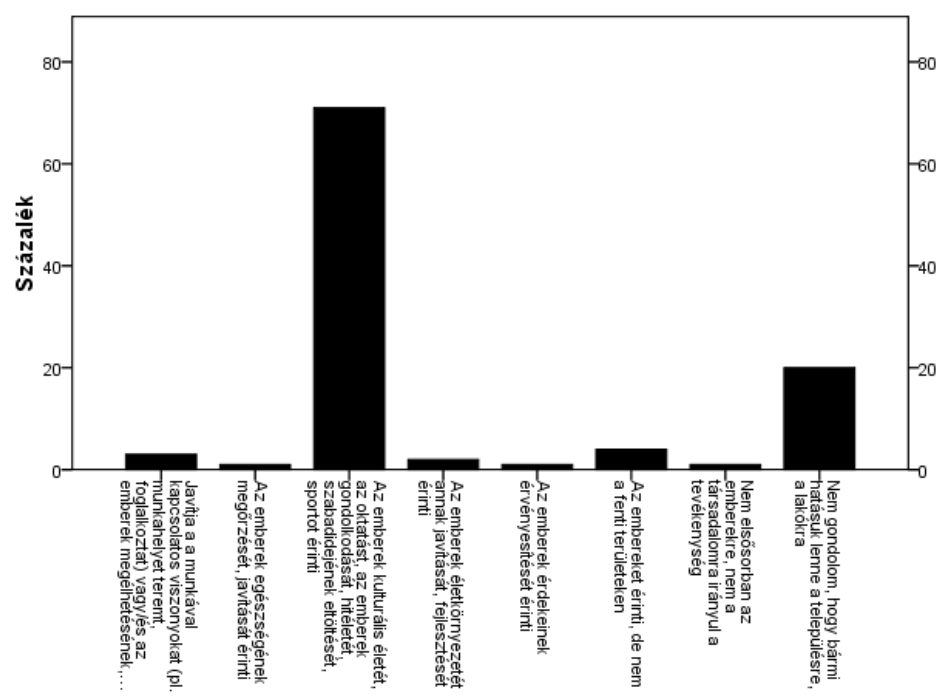

3. ábra: Az vizsgált minta véleményének megoszlása az érintettség területeiről.

Forrás: Saját vizsgálatok, 2013. 
A civil szervezetek hatása a településen az eredmények alapján elsősorban kulturális területen, oktatási területen, az emberek hitéletében, gondolkodásában, szabadidőjének eltöltésében, és a sport területén érezhető. Ez egy viszonylag magas arány, $71,4 \%$-a a megkérdezetteknek ezeket a területeket jelölte meg. A további eredmények tekintetében úgy vélhető, hogy a munkával és megélhetéssel kapcsolatos viszonyok terén a helyi civilek hatása alig érezhető $(3,1 \%)$, hasonlóképp az egészségjavítás $(1,0 \%)$, életkörnyezet javítás $(2,0 \%)$, az érdekérvényesítés $(1,0 \%)$, egyéb, az emberekkel kapcsolatos terület $(4,1 \%)$, illetve nem az emberekkel kapcsolatos területekhez (1,0\%). A megkérdezettek 20,4\%-a úgy gondolta, hogy a civil szervezetnek nincs hatása a településre, a lakókra. Összességében tehát az érintettség fókusza kulturális, hitéleti, oktatási, gondolkodási, szabadidő eltöltési, sport területeken jelentkezik, majd háromnegyed arányban, ezen kívül ugyanakkor a civil szervezete hatása alig érezhető, sőt a megkérdezettek egy ötöde szerint nincs is hatása a településre és a lakókra. Úgy tünik a civilek hatóspektruma tehát nem széles, és csupán néhány területre koncentrált.

A vizsgálat utolsó kérdése azt mérte, hogy milyen a civil szervezetek hatásának erőssége. Az eredmények arra utalnak, hogy a civil szervezetek helyi hatása inkább közepes, vagy attól gyengébb (4.ábra)

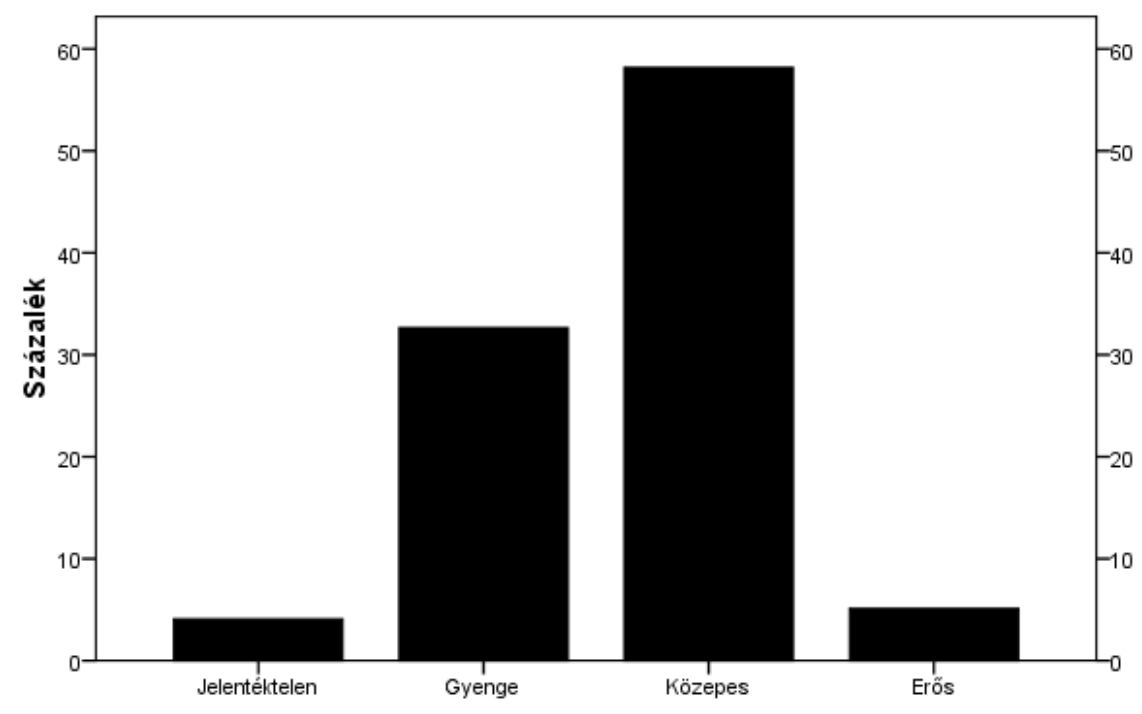

4. ábra: Az vizsgált minta véleménye a civil szervezetek hatásának erősségéről. Forrás: Saját vizsgálatok, 2013. 
A megkérdezettek az ötfokú skálán négy választ jelöltek meg csupán, ezekböl az látható, hogy a válaszadók mindössze $5 \%$-a szerint erös a civil szervezetek hatása, $4 \%$ véleménye szerint ezzel épp ellenkező, azaz jelentéktelen, 32,7\% szerint hatásuk gyenge, és $58,2 \%$ szerint a civil szervezetek hatása közepes a településre vonatkozóan. Főként a fiatalok szerint erősebb a hatás, egyéb összefüggés ebben a tekintetben nem mutatható ki. A hatás erősségét elsősorban a középfokú végzettségüek jelezték, más összefüggés ebben a tekintetben sem volt kimutatható. A munkanélküliek tekintetében a hatás inkább gyengébb, hasonlóan a foglalkoztatottakhoz és a nem munkaképes korúakhoz, az inaktívak tekintetében ez inkább közepes erősségü. Az érintettségi görbe úgy tűnik, hogy erősen balra tolódott, így a civil szervezetek hatása a helyiek szerint inkább közepes, vagy annál gyengébb.

\section{Következtetések}

A civil szervezetek szerepének, jelentőségének, hatásának mérése alapvetően egy komplex tevékenység, és ahhoz, hogy valós képet kapjunk, egyrészt az adatok részleteit is ismerni kell, másrészt többféle adatforrásra is érdemes támaszkodni. Különösen konkrétumok alkalmával lehetnek problémák, ha a KSH-t tekintjük javarészt több mint 2 éves adatokkal lehet találkozni, és a részletek ilyenkor is legtöbbször az önkéntesek és tagok számában merülnek ki. Az érintettség újabb változókat is bevezet, és jobb becslést adhat - érvényessége miatt egy vizsgált populáció viszonyairól.

A saját eredmények kapcsán -a vizsgált település tekintetében- arra lehet következtetni, hogy a civil szervezetek hatása helyileg nem igazán erős. A vizsgált településen a lakosság többsége vél valamiféle összefüggést felfedezni a civil szervezetek és társadalom, az élet javítása között, de ez nem igazán meghatározó. A lakosok többsége inkább közepesen vagy gyengén érintett, közel egyharmaduk semmiféle formában nem érintett. A civil szervezetek hatása a helyiek szerint inkább közepes, vagy annál gyengébb. Helyi szinten a civil szervezetek jelenlegi vizsgálataim, területeim és módszereim tekintetében - nem elég erősek jelenleg a neki tulajdonított feladatok ellátásban és társadalomra kifejtendő hatásukban. Különösen érvényes ez olyan területen, mint például a munkahelyteremtés vagy bővítés, mely helyileg igen fontos lenne. Érdekes lehetne megtudni, hogy vajon mit is várnak a helyiek a két müködő civil szervezettől, vajon mivel tudnának a helyiek maguk is hozzájárulni a szervezetekhez, afféle települési erőforrás és szakértelem leltár tekintetében vélhetően további párhuzamokat lehetne kiépíteni a szervezetek és a helyi lakosság között. 


\section{Irodalomjegyzék}

1. Bácsné Bába É. (2012): Változásmenedzsmenthez kapcsolódó reakció idő vizsgálatok. In: Virtuális Intézet Közép-Európa kutatására Közleményei IV. évf. 2. szám (No.8.) A-sorozat 1. Gazdálkodás- és szervezéstudományi tematikus szám 2012. Szeged, pp. 66-74.

2. Brint, S., Levy, C.S. (1999). "Professions and Civic Engagement: Trends in Rhetoric and Practice, 1875-1995." In: Skocpol, T. - Fiorina, M.P. (ed.): Civic Engagement in American Democracy. Brookings Institution Press; Russell Sage Foundation. Washington, D.C.; New York.

3. Cartwrigh, A., Sik E., Svensson S. (2008): The Impact of Civic Engagement on The Quality of Life in Hungary. Social Capital Working Papers 2008/3.Central European University, Budapest.

4. Cnaan, R.A., Milofsky, C. (ed.)(2007): Handbook of Community Movements and Local Organizations (Handbooks of Sociology and Social Research). Springer.

5. Ibrahim, S., Hulme, D. (2010): Has civil society helped the poor?-A review of the roles and contributions of civil society to poverty reduction. BWPI Working Paper 114. University of Manchester Brooks World Poverty Institute. http://www.bwpi.manchester.ac.uk/resources/Working-Papers/bwpiwp-11410.pdf (2012.12.25)

6. Móré M. (2012): Hátrányos helyzetűek és romák munkaerőpiaci visszailleszkedésének segítése tanácsadási módszerekkel. In: Gortka Rákó E. (szerk): Társadalomtudományi Tanulmányok V. DUPress Kiadó Debrecen pp. 69-77.

7. Murányi I., Szerepi A. (2005): Civil esélyek Hajdú-Bihar megyében. Hajdúsági Hallgatói Önkormányzatok Kulturális Egyesülete,Debrecen. 54 p.

8. Oláh J. (2008): A szociális gazdaság jellemzői Magyarországon. „Hagyományok és új kihívások a menedzsmentben: 140 éves a vezetés és szervezés oktatása a debreceni gazdasági felsőoktatásban" c, nemzetközi konferencia. Szerk.: Dienesné Kovács E.- Pakurár M. Debreceni Egyetem, Debrecen, 2008. október 2-3. 450-456.p. ISBN: 978-963-9822-08-5.

9. Utasi Á. (2012): Közösségi és közéleti aktivitás. Vizsgálat három ország hét magyar kistelepülésén. MTA TK Politikatudományi Intézet, Budapest.

Szabados György: egyetemi adjunktus

Debreceni Egyetem, Vezetés és Szervezéstudományi Intézet, Vezetéstudományi Tanszék

4028 Debrecen, Böszörményi út 138. 


\section{UNIVERSITY \\ OF DEBRECEN}

FACULTY OF

HEALTH

NYÍREGYHÁZA

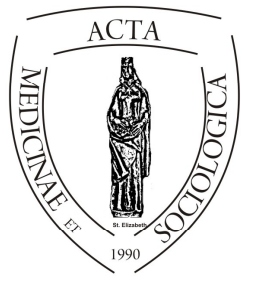

ACTA

MedSoc

VOLUME 5.

2014

\title{
A vezetési stílus, a változási készség és a konfliktus kezelés vizsgálata egy magyar- országi Multinacionális vállalatnál
}

\author{
Sipos Gábor - Szücs Edit - Takács Tímea - Matkó Andrea \\ Debreceni Egyetem Müszaki Kar Müszaki Menedzsment \\ és Vállalkozási Tanszék
}

\begin{abstract}
The study purpose to examine what leadership style is used by a successful Hungarian multinational company for the efficient and effective working. In addition the corporate leaders how to respond for the adaptation challenge caused by changes in the external environment, meaning what the change skills. Conflict is a common phenomenon in organizations because of intense competition. Conflict management is a major test of the best professionals. Our research purpose of to examine leadership style, change skills and conflict management in the company. We set several goals in our research and we used descriptive statistics.
\end{abstract}

Keywords: Harsey-Blanchard model, leaders, leadership styles, conflict management, change skill 


\section{BEVEZETÉS}

A szervezetek vezetésének tudománya egyre nagyobb jelentőséggel bír, és egyre jobban felértékelődik korunkban. Ennek több oka is van. Az egyik a gazdasághoz köthetö, mely szerint a vezetés kulcsfontosságú szerepe abban nyilvánul meg, hogy növelje a termelékenységet az erőforrások optimális összehangolásával, és ez által kielégítse a társadalom anyagi szükségleteit. A másik ok társadalmi eredetü. A vezetés formálja az egy csoportban, egy közös célért dolgozó emberek társadalmi kapcsolatait, ezáltal közösségi szellemüket és tudásukat is fejleszti. A harmadik ok pedig a vállalatokkal kapcsolatos. A szervezetek célja napjainkban a minél nagyobb profit szerzése, a hatékonyság növelése, a piacon való stabil elhelyezkedés és természetesen a fennmaradás. Mindezekhez elengedhetetlen a vállalat összes funkciójának eredményes müködése. A szerepekkel pedig szervesen összekapcsolódik a vezetés, minden funkcióban jelentőséggel bír, és egyiktől sem választható külön.

A vezető tevékenysége sokrétü, felelősséggel tartozik a szervezet sikeres müködéséért. Emellett személyes példamutató szerepet tölt be alkalmazottai és a külvilág felé. A külső körülményekhez való alkalmazkodás gyorsaságában a vezetők fontos szerepet játszanak. Megfogalmazzák a vállalat jövőképét, értékeket, és irányelveket határoznak meg a szervezetben dolgozóknak. A célok és célkitüzések képessé teszik a szervezetet a rövid és hosszú távú eredmények eléréséhez.

Kutatásunkat egy debreceni, nagy múltra visszatekintő multinacionális vállalatnál végeztük. A vállalat életében a hosszú és rövid távú célkitüzések a vezetés részéről meghatározóak, illetve maga a vezetés is szerves részét képezi a vállalat sikerességének. Kutatásunk során megvizsgáltuk a vállalat esetében a vezetési stílust, a változási készséget és a konfliktuskezelést. Azért fokuszáltunk erre a három területre, mert a kialakult gazdasági helyzet és a gyorsan változó környezeti feltételek számos kihívást támasztanak a vezetőkkel szemben. Ennek ellenére a cég folyamatosan növekvő tendenciát mutat, melynek eléréséhez és fenntartásához szükséges a megfelelö vezetés és a különböző változásokra való készség. A 2008-as gazdasági válságban a gyár közel 50\%-os termeléscsökkenés ellenére felismerte, hogy a jövő kihívásaira megfelelően fel kell készülni, ezért a tartalékait, melyek a termeléskiesésből adódtak folyamatjavításra és optimalizálásra használták fel. A változások következtében felmerülö konfliktusok, változási hajlandóság megfelelö és hatékony kezelése tette a vizsgált szervezetet egy folyamatosan növekvő, fejlődő sikerorientált vállalattá.

Kutatásunk célja, hogy a vállalaton belül definiált három vezetői szint vezetési stílusát, változási készségét és konfliktuskezelési módját megvizsgáljuk. 


\section{LEADERSHIP}

A leadership rendkívül sokrétü és összetett fogalom, mely a szervezet magatartásával foglalkozik. A szakirodalom szerint nem egyértelmü, hogy a vezetői magatartásról, a vezetői stílusról, a vezetői szerepről vagy a vezetői funkciókról beszélünk. Minden megközelítés helytálló, de egy megközelítés sem léphet fel a teljes értelmezés igényével. A nemzetközi irodalomban fellelhető fogalmi és definíciós vita mellé a magyar nyelv fordításbeli nehézségek miatt többféle értelmezés társul. A legtöbb leadership definíció a következő föbb elemeket hangsúlyozza: a befolyásolás, a csoport és a cél. Bakacsi (2004:184) definíciója alapján: „a leadership a vezetői tevékenység egy olyan eleme, amely a szervezeti erőforrások közül kitüntetetten az emberi erőforrással foglalkozik (a vezető és beosztottai közötti kapcsolat módjára keresi a választ)." Annak képességét jelenti, hogy hogyan tudja a vezető a szervezet tagjait a szervezeti célok megvalósítására befolyásolni, mozgósítani (Karácsonyi, 2006).

\subsection{LEADERSHIP ELMÉLETEK}

A leadership elméletek sajátossága abban rejlik, hogy egy vezető hogyan tudja a saját alkalmazottainak értékeit, szükségleteit felismerni, összekapcsolni és hatékonyan mozgósítani. Az alkalmazott vezetési stílus több tényezőtől függ: a vezető személyiségétől, a beosztottak és a szervezet, a környezet viselkedésétől, a vezetőtől, a csoporttól, a szervezet céljaitól és szükségleteitől.

\section{Hersey és Blanchard kontingencialista elmélete}

A sikeresség alapja a vezető tudatos erőfeszítése, illetve a változó helyzetekhez való alkalmazkodási képesség mozgósításnak képessége, vagyis a vezető tartja kezében a problémákra a megoldás kulcsát, abban a tekintetben, hogy mennyire képes az adott helyzet, szituáció felmérésére, diagnosztizálására és a kialakult helyzethez / helyzetekhez hogyan tudja igazítani a stílusát, viselkedését. A vezetés akkor hatékony, ha minden szempontból megfelel annak a szituációnak, amelyben alkalmazni kell (Bakacsi, 2004).

A helyzethez igazított vezetés alapelemei:

- feladatra figyelés

- kapcsolatra figyelés

- a munkatárs és a feladat jellemzői

- a vezető igényei (FN24, 2011). 
Az egyes stílusokhoz jellemző vezetői viselkedéseket Hersey és Blanchard fogalmazták meg (Ford, 1995). Elméletük szerint a vezetöknek váltogatni kell az egyes vezetői stílusok között, azonban a vezető stílusát meghatározza a beosztottak érettsége. A beosztottak értettségének növekedésével a kapcsolatorientált stílusok eredményesebbek. Az érettség egy adott szintje felett engedni kell, hogy a beosztottak akarata érvényesüljön. Ezért a modell független változója a követők személyiségének érettsége. A modell szerint négy egymástól jól elkülöníthető vezetői stílust különböztetünk meg (1. ábra).

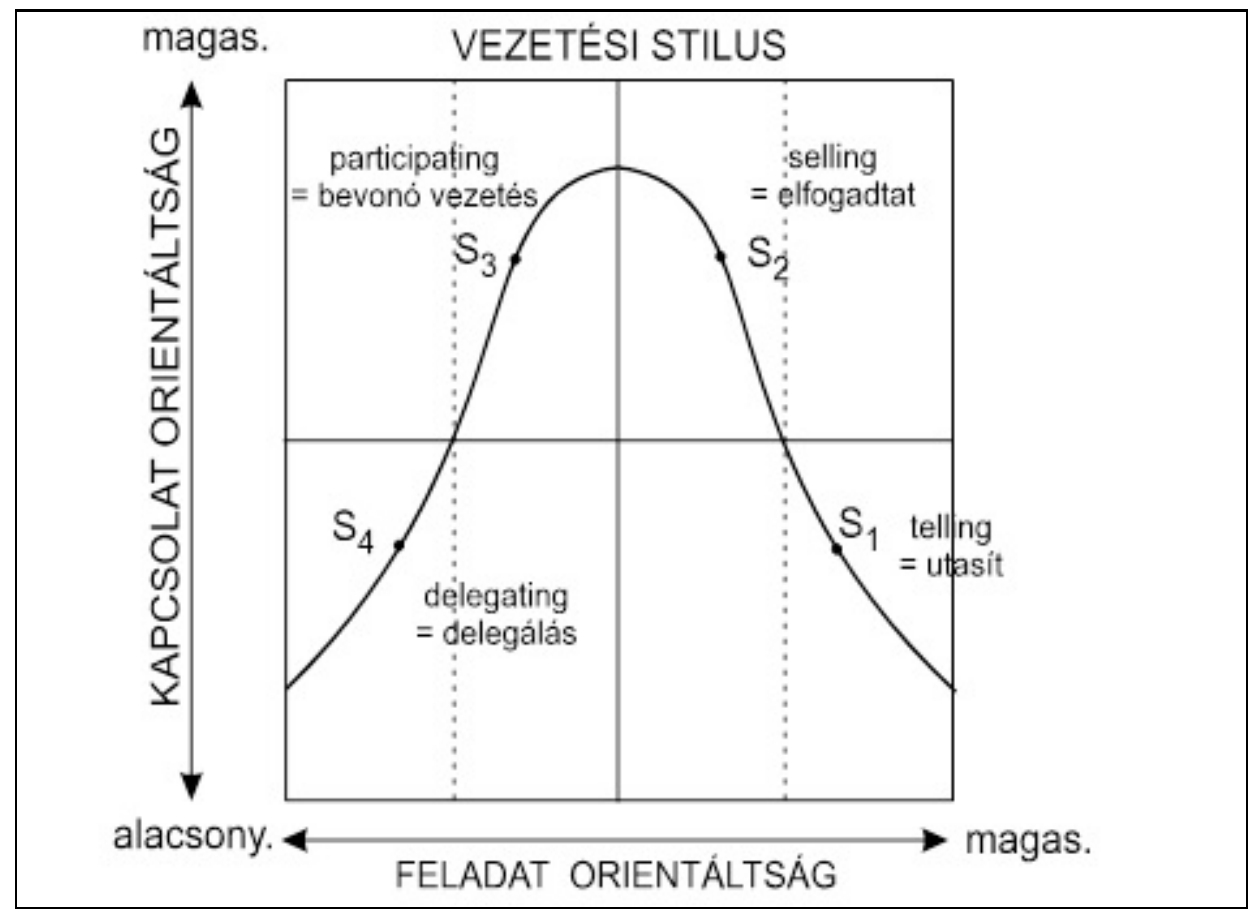

1. ábra: Hersey és Blanchar szituációs modellje (Forrás: Gyökér, 2006:15)

Az ábra alapján láthatjuk, hogy Hersey és Blanchar négy vezetöi típust különít el a kapcsolat orientáltságának szintje szerint, modelljük a feladat- és a kapcsolatorientált magatartásokat tükrözi.

S1. Utasitó vezetés: Erős feladat-, gyenge kapcsolatorientáltság jellemzi a vezetőt. A vezető tudja mit akar, és világosan el is mondja a beosztottainak. Világos 
egyértelmü utasítások jellemzik, erős szabályozó és ellenőrző funkció. Gyakran például erre van szükség az újonnan belépő dolgozók esetében.

S2. Elfogadtató vezetés (Coaching): Erős feladat- és kapcsolatorientáltság jellemzi a vezetőt. A vezető részletesen elmagyarázza a teendőket. Kétirányú kommunikációra és motivációra épülve igyekszik bizalmat ébreszteni a dolgozókban, de a döntések felelősségét, az ellenőrzést a vezető nem adja ki a kezei közül. A humánus hozzáállás, a csoportmunka, a szabványok tudatosítása a munkacsoport szempontjainak mérlegelése és a folyamatok szabályozása jellemzi ezt a vezetői stílust. Ez a stílus a leginkább még nem tapasztalt kezdő dolgozók számára a megfelelö.

S3. Bevonó vezetés (szupportiv): Gyenge feladat-, erős kapcsolatorientáltság jellemzi a vezetőt. Ezen stílus esetén a vezető és a csapat együtt dönt. A vezető ebben az esetben azon van, hogy a munkába és a döntéshozatalba mindenki be legyen vonva és a munkatársak támogatva érezzék magukat.

S4. Delegáló vezetés: Gyenge feladat- és kapcsolatorientáltság jellemzi a vezetőt. A vezető önállóságot ad a beosztottainak. Célokat a munkatársak határozzák meg és a problémákat szintén ők oldják meg és mindezt a vezető egyfajta támogatásával teszik (Ford, 1995).

A vezetési stílus mellett nagyon fontos, hogy a vezető milyen változási készséggel rendelkezik, mert a vállalat sikeressége és hatékonysága függ a vezető reagálási gyorsaságától és alkalmazkodási készségétől.

\section{VÁLTOZÁSI KÉSZSÉG}

Napjainkban a dinamikusan változó gazdasági környezet, a kiélezett versenyhelyzet következtében elengedhetetlen a folyamatos változás, amelyre a vezetőknek állandóan reagálnia kell. Megkülönböztetünk tervszerú és váratlan, külső hatásokra létrejövő változást. A tervszerü szervezeti változásoknak fő célja a vállalat, a vállalkozás alkalmazkodó-képességének fejlesztése, míg a váratlan hatásokra létrejövő változás célja a kedvezötlen hatások kiküszöbölése. A vezetésnek nemcsak a hagyományos vezetői feladatokkal kell megbirkóznia, hanem a változások folyamatos menedzselésével is. A változtatás kezdeményezése egy szervezeten belül nagyon fontos elhatározás. Bevezetése minden esetben kivált kisebb-nagyobb ellenállást a szervezeten belül, melynek fő oka a bizonytalanság. $\mathrm{Az}$ emberek gyakran bizonytalanok a változás hatását illetően. Ezért a mene- 
dzser első lépése a problématerület feltérképezése, körülhatárolása, illetve a probléma típusának tisztázása. Ehhez különböző felméréseket kell végezni. A felmérésekkel és a megismerési modellek alkalmazásával a menedzser eljut a valódi probléma felismeréséhez, és a probléma jellegének, típusának tisztázásához (Vezetés nincs szerző?, 2009).

A változtatási folyamat elsö fázisa a diagnóziskészítés, amely a rendszer leírásával (modellezésével) kezdődik. A rendszer a teljes érintett körnek a bevonásával történik. Ebben a fázisban fontos, hogy a rendszer leírása közben közvetlen kontaktus legyen a „problémagazdákkal”, azaz a tényleges döntéshozókkal. A folyamatot addig kell folytatni, amíg ki nem alakul a konszenzus a résztvevők között.

A második fázis a célok és a korlátok rögzítésével folytatódik. Tisztázni kell a változással elérni kívánt célokat, továbbá azokat a korlátokat, amelyek között a változás reálisan megvalósítható. A célok és korlátok leírása a rendszerleíráshoz hasonlóan egy interaktív folyamat. Ebben a fázisban természetesen megfogalmazódhatnak olyan célok is, amelyek nyíltan vagy burkoltan azt sugallhatják, hogy a változásra semmi szükség nincs.

A harmadik fázis a változtatás stratégiájának kialakítása. Ha a probléma tisztázódott és az okok ismertté váltak, akkor ki kell alakítani a változtatás alapvető stratégiáját. A stratégia részvételen alapuló döntés-előkészítési folyamatában arra kell különös figyelmet fordítani, hogy kiderüljön, mit akarnak a résztvevők. Arra kell törekedni, hogy a zavaros helyzetek határvonalai egyértelmủek legyenek, ezzel sok későbbi meddő vita megelőzhető. A zavaros helyzet úgy tehető kezelhetővé, áttekinthetővé, hogy a legfontosabb külső és belső kapcsolatok azonosításával meg kell próbálni a struktúrát felvázolni és megérteni. Azt is el kell érni, hogy a célokban és a korlátokban azonos értelmezés jöjjön létre az együtt dolgozók körében.

A negyedik fázis a változtatások részletes akcióterveinek elkészítése. Ebben a szakaszban kerül sor a változtatást elősegítő alternatívák kidolgozására, amelyek egyelöre még nem kész és teljes csomagterveket, hanem a célok elérését biztosító akciókat, megoldási módokat tartalmazzák.

Itt előfordulhat, hogy a változtatást előkészítő csoport külső segítségre szorul. Ilyenkor bevonhatók a munkába olyan külső szakemberek, tanácsadók, akik több információval rendelkeznek bizonyos müszaki, gazdasági, piaci stb. kérdésekről.

Az ötödik fázis a változtatási döntések meghozatala. A szóba jöhető - reálisnak mutatkozó - akciók részletes kimunkálására (modellezésére) és komplex értékelésére egy következö lépésben (de még a tervezésen belül) kerül sor.

Ennél a munkánál az egyes alternatívákat ajánlatos a célrendszer paraméterei szerint leírni, és az előre felállított döntési kritériumok alapján, a megfelelő döntési módszer alkalmazásával a legkedvezőbb cselekvési változatot kiválasztani. A különféle lehetséges cselekvési változatokból végül is egyetlen, megvalósításra előkészített változtatási akciótervet kell kialakítani. 
A cselekvési változatok modellezését és a megvalósításra javasolt akcióváltozat kiválasztását követően kell átlépni a hatodik fázisba, mely a megvalósítás előkészítési szakasza. A gyakorlati megvalósítás első lépéseként a döntéshozónak határozni kell a megvalósítás módszeréről, mely lehet:

- gyors, általános bevezetés, átalakítás (áttörés) (pl. a közlekedési rendben történő változtatás);

- fokozatos bevezetés (pl. a számítógép alkalmazásakor először csak egyegy részterületen);

- kísérleti bevezetés (pl. egy marketingakció esetén) (Vezetés, 2009).

A változások kezelése az egyik legbonyolultabb feladat a vezető számára, a siker elérése érdekében a vezetőnek nem megoldásokra, hanem magára a folyamatra kell koncentrálnia. A dolgozóknak különböző munkákban kell jártasnak lenniük ahhoz, hogy új megoldásokat találhassanak, ennek következtében fontosabb a dolgozók képessége az új ismeretek elsajátításához, mint egy adott szakma ismerete (Vezetés, 2009).

A változások gyakran együtt járnak a konfliktusokkal, a dolgozók reagálása a változásokra, az ismeretlen dolgoktól való félelem és a folyamatosan változó gazdasági- és társadalmi helyzet következtében.

\section{KONFLIKTUSKEZELÉS}

A konfliktusok napjainkban minden szervezetben jelen vannak, ezért is fontos vizsgálnunk, hiszen a vezetési stílushoz és a változási készséghez hogyan kapcsolódik a konfliktuskezelés módja. A konfliktus számos okból kialakulhat, mely pozitívan és negatívan is befolyásolhatja a munkavégzés módját.

A konfliktus belső állapot, amelynek során a személyben a látszólagos vagy ténylegesen össze nem egyeztethető, ellentétes erők, motívumok egyidejüleg hatnak. A konstruktív konfliktusok a fejlödés mozgató rugói, amikor a konfliktus megoldása fejlődést eredményez. Azonban létezik destruktív konfliktus is, amely a legjobb szándék mellett is a kapcsolatok romlásához vezetnek (Balogh, 2000). A valóságban nem minden konfliktus baj, a konfliktusokat mindig adott helyzetben, adott összefüggésében kell megítélnünk. A konfliktus megoldása egyaránt jelenthet sikert és kudarcot, tehát ennek megfelelően kell foglalkoznunk vele a mindennapi és vezetői tevékenységben egyaránt (Zrinszky, 1985). 


\section{Konfliktusmegoldó stratégiák}

A vezető érdeke, vagy célja ütközhet a társak, a partner érdekével, véleményével, ami konfliktust (konfliktushelyzetet) eredményez. A vezetői lét velejárója a vita és a konfliktus. A konfliktushelyzetek azok a szituációk, amelyekben az emberek törekvései összeegyeztethetetleneknek tünnek.

A viselkedések alapján a konfliktusok kezelésének öt alapvető formáját különböztetjük meg:

1. Versengő - Vitatkozó: Az egyén saját szándékait érvényesíti a másik személy rovására bármely befolyásolási mód (meggyőzőképesség, rang, gazdasági szankció stb.) alkalmazásával azért, hogy jobb helyzetbe kerüljön. A versengés jelentheti a saját igazáért való kiállást, a helyesnek vélt álláspont védelmét vagy egyszerüen a győzelemre való törekvést (Poór, 2013; Mikulás, 1999).

2. Alkalmazkodás - Együttmüködés: Az egyén lemond a saját szándékáról, hogy a másik fél szándékai is érvényesülhessenek. Bizonyos önfeláldozás van ebben az eljárásban. Az alkalmazkodás öltheti az önzetlen nagyvonalúság vagy a jótékonyság formáját, de lehet a másiknak való kényszerü engedelmesség, illetve a másik szempontjainak, érveinek őszinte elfogadása is (Poór, 2013; Mikulás, 1999).

3. A közös megoldás keresése - Megállapodó: Magában rejti azt a törekvést, hogy együtt dolgozva a másik személlyel alakítsanak ki valamilyen megoldást, amely "teljesen" megfelel mindkét fél szándékainak. A közös megoldás keresése lehet pl. egy nézetkülönbség mélyebb feltárása azzal a céllal, hogy egymás megértése révén okuljanak a felek, vagy valamilyen feltétel megteremtésére való szövetség, amelynek hiánya versengésre késztetné a feleket (Poór, 2013; Mikulás, 1999).

4. Elkerülés - Tartózkodó: Az egyén nem követi közvetlenül sem saját, sem a másik fél szándékait. Az elkerülés lehet a diplomatikus kitérés, a kérdés kedvezőbb időpontra való halasztását, vagy egyszerűen visszahúzódást egy fenyegető helyzetből (Poór, 2013; Mikulás, 1999).

5. Kompromisszum keresés - Alkalmazkodó: A cél valamilyen kivitelezhető és kölcsönösen elfogadható megoldás találása, amely részlegesen mindkét felet kielégíti. Közvetlenül ragadja meg a kérdést (értelmezi a helyzetet), mint az elkerülő, de nem tárja fel olyan mélységig, mint a problémamegoldó. A kompromisszum keresése félúton való találkozás, kölcsönös engedményeket vagy egy gyors, áthidaló megoldás keresését jelenti (Poór, 2013; Mikulás, 1999). 


\section{EGY MULTINACIONÁLIS VÁLLALAT VEZETÖINEK VIZSGÁLATA}

Napjainkban a dinamikusan változó gazdasági környezet és a kiélezett versenyhelyzetben a vezetés fontos szerepet játszik egy vállalat estében. A vezetési stílusok, változási készségük és konfliktuskezelésük hatással van a vállalat sikerére.

Vizsgálatunkban ezért egy debreceni multinacionális vállalatot vezetőit vontuk be, azért mert a vállalat hosszú múltra tekint vissza, illetve a vezetés három szintjét lehet náluk elkülöníteni, mely árnyaltabb képet adhat számunkra, hogy az egyes szinteken milyen eltérések és hasonlóságok mutatkoznak a vezetési stílusban, a konfliktuskezelés módjában, illetve a változási készségben.

Vizsgálatunk alapját a vállalat egészét tekintve 89 vezető képezte, mind a vezetési stílus, változási készség, mind a konfliktuskezelés tekintetében. Ebből 12 fö felső vezető, 28 fő középvezető és 49 fő operatív vezető. A vezetés vizsgálata során három fajta kérdőívet használtunk fel. Az első kérdőív a vezetési stílust vizsgálta, mely segít behatárolni, jellemezni az egyes vezetők vezetési stílusát. A második kérdőív a változási készséget vizsgálta, hogy milyen gyorsan és milyen mélységben tudnak az egyes szinteken lévő vezetők alkalmazkodni az új helyzetekhez. A harmadik kérdőív a konfliktusok kezelését vizsgálta, azt hogy az vezetők milyen módszerrel oldják meg a vállalaton belül kialakult konfliktusokat. Az eredmények értékeléséhez leíró statisztikát alkalmaztunk

A kutatás célkitüzései:

- Megvizsgálni, hogy a különböző szintủ vezetők eltérő vezetési stílust alkalmaznak-e.

- Megvizsgálni, hogy a három szint vezetői milyen konfliktuskezelési módot alkalmaznak.

- Megvizsgálni, hogy a három vezetöi szint milyen mértékben tud alkalmazkodni a változásokhoz.

Vizsgált vezetői csoportok:

- Felsővezetők: A legfelső vezetést képezik. Magas döntési jogkörrel rendelkeznek. Anyagi döntési jogkörük összeghatárhoz van kötve.

- Középvezetők: Közvetlenül a felső szintű vezetés alatt helyezkednek el, a vezetés második szintjén. Döntési jogkörük magas, aláírási jogkörrel rendelkeznek. 
- Operatív vezetés: A vezetés harmadik szintjét a vállalatnál lévő csoportok vezetői képezik. Kisebb területek irányításáért felelősek, aláírási joguk nincs, döntési jogkör csak a saját területükön van. Anyagi, döntési jogkörrel nem rendelkeznek, függenek a feletteseiktöl.

\section{Vezetési stílus vizsgálata}

A vizsgálatunkhoz Hersey és Blanchard szituációs modelljét alkalmaztuk. A modellnek megfelelöen megvizsgáltuk, hogy a vállalat esetében az egyes vezetői szinteken milyen vezetési stílusok jellemzőek. A vizsgálat eszköze Mikulás Gábor (1999) Menedzsment címü könyvéből származó önkitöltős kérdőív volt, amely 12 kérdésből állt. Minden kérdés esetében 4 válaszlehetőséget sorakoztat fel, amelyek közül a vizsgált vezetőknek a rájuk leginkább jellemzőt kellett kiválasztaniuk.

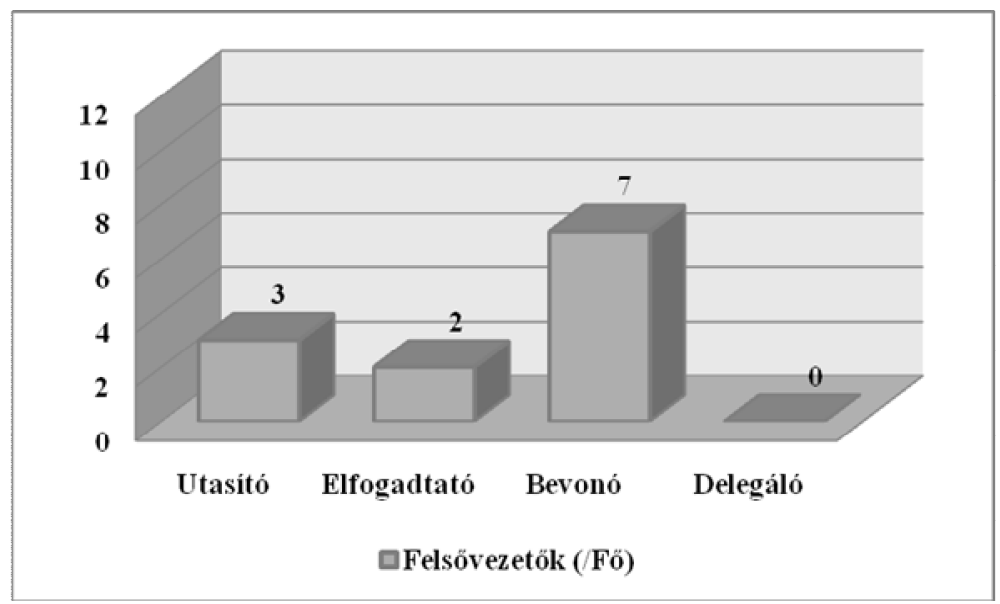

3. ábra: Felsővezetők vezetési stílusa

(Forrás: saját adatbázis alapján)

A felsővezetők stílusaira vonatkozó eredményeket a 3. ábra szemlélteti. Láthatjuk, hogy legmagasabb számban (7fö) a bevonó vezetési stílust alkalmazzák. Erre a vezetési stílusra jellemző, hogy a vezető a beosztottjait bevonja a munkába és a döntéshozatalba egyaránt. A felsővezetőkre azért jellemző ilyen magas arányban ez a fajta vezetési stílus, mert ők már régóta dolgoznak a vállalatnál, ugyanazzal a csoporttal, munkatársakkal végzik közösen a feladataikat, így kialakult az a fajta együttmüködés és bizalmi légkör a munkájuk során, amely magával vonja a bevonó vezetési stílust. Az ábra alapján látható, hogy a delegáló vezetési stílust a felsővezetők nem alkalmazzák a munkájuk során. A felső szin- 
tủ vezetésre jellemző az, hogy az egyes feladatokat delegálják a beosztottjaiknak, így önállóságot adva nekik. Az utasító és az elfogadtató vezetési stílus már magas számban (3 és 2 fö) jellemzi az egyes szintű vezetést. Ez a két vezetési stílus azokra a vezetőkre jellemző, akiknek újonnan érkezett, belépő, kezdő és tapasztalatlan dolgozókat kell irányítaniuk. A felső vezetésnek pedig általában már összeszokott, tapasztalt munkatársakkal kell együttmüködniük.

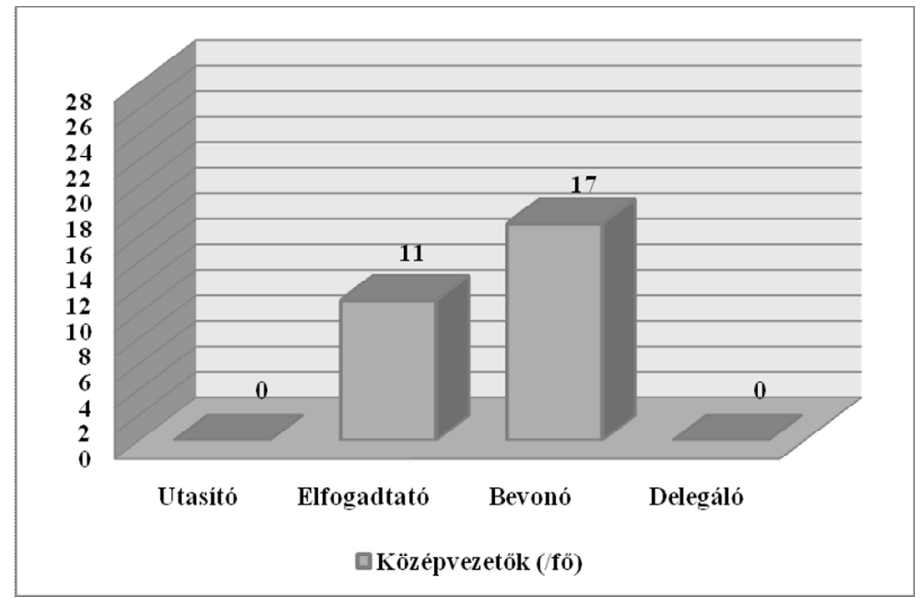

4. ábra: Középvezetők vezetési stílusa

(Forrás: saját adatbázis alapján)

A 4. ábrán láthatjuk a középvezetők által alkalmazott vezetési stílusokat. A legmagasabb számban (17 fö) a bevonó vezetési stílust alkalmazzák. Ezen a vezetési szinten pedig fontos, hogy a vezetö és a csoport közösen hozzanak döntéseket, a munkába és a döntéshozatalba mindenkit bevonjon a vezetö és így a munkatársak támogatva érezzék magukat. Ezeket pedig a bevonó vezetés segítségével tudja a vezető megvalósítani. Az elfogadtató vezetési stílus alkalmazása is magas értéket kapott (11 fö). Ezt a vezetési stílust jellemzően akkor alkalmazzák, amikor még kevéssé tapasztalt dolgozókkal kell együttmüködnie a vezetőnek. A középvezetők esetében pedig ez gyakran előfordul, hiszen munkakörükből adódóan folyamatosan változó összetételü csapatokat kell irányítaniuk. Az utasító és a delegáló vezetési stílus egyáltalán nem jellemző a középvezetőkre a vállalatnál. Az utasító vezetési stílusra az erős szabályozottság, ellenőrzések, míg a delegáló stílusra pedig a magas önállóság és szabadság a jellemző. A középvezetés viszont ezzel szemben olyan dolgozókat és munkacsoportokat irányít, ahol nem jellemző az, hogy a vezető magas önállósággal és szabadsággal ruházza fel az alkalmazottait. 


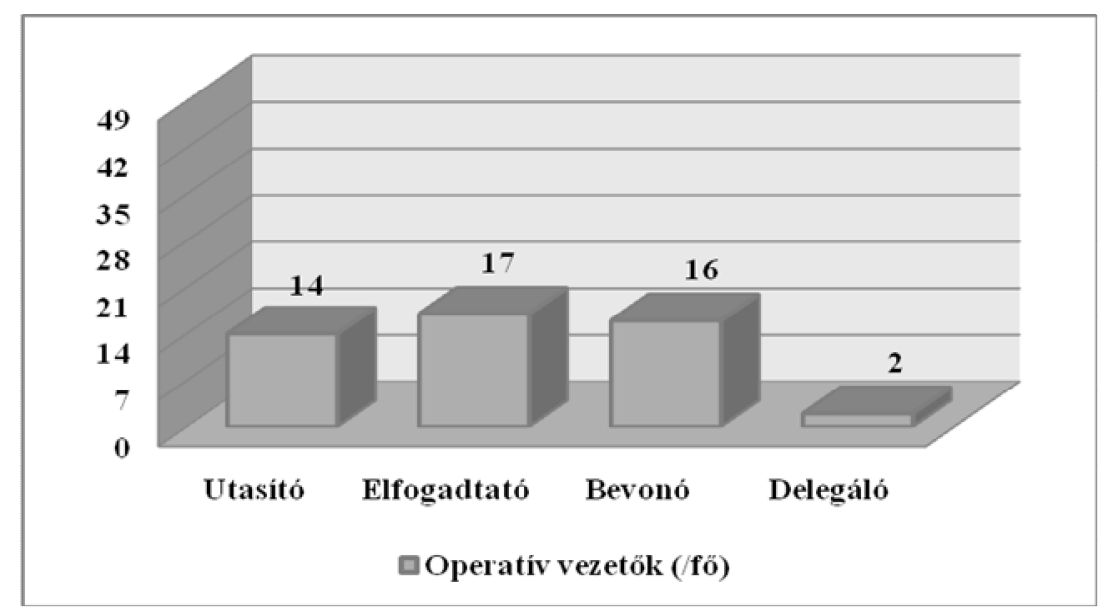

5.ábra: Operatív vezetők vezetési stílusa

(Forrás: saját adatbázis alapján)

Az 5. ábrán láthatjuk az operatív vezetésre jellemző vezetési stílusokat. Az operatív vezetők esetében a legmagasabb arányban az elfogadtató vezetési stílus alkalmazása a jellemző (17 fö). Erre a vezetési stílusra jellemző, hogy a vezető részletesen elmagyarázza a teendőket az alkalmazottaknak, hiszen ez a vezetési stílus a kevéssé tapasztalt dolgozók esetében alkalmazandó. A másik legjellemzőbb vezetési stílus az operatív vezetők esetében az utasító stílusú vezetés (14 fö). Ezt a vezetési stílust az újonnan érkező, belépő dolgozók esetében alkalmazza a vezetés. Ebből adódóan a vezetőt világos és egyértelmü utasítások és erősen szabályozó és ellenőrző funkció jellemzik. A bevonó vezetés is magas értéket kapott (16 fó). Ezt a vezetési stílust magasabb szinteken dolgozók vezetésekor alkalmazzák, ami nem jellemző az operatív vezetőkre. A delegáló stílusú vezetés kevéssé jellemző (2 fö). Ennek oka szintén az, hogy ezt a vezetési stílust már jól összeszokott csapatok esetében alkalmazzák, amelyek nem jellemzőek a cég esetében az operatív vezetésre. 


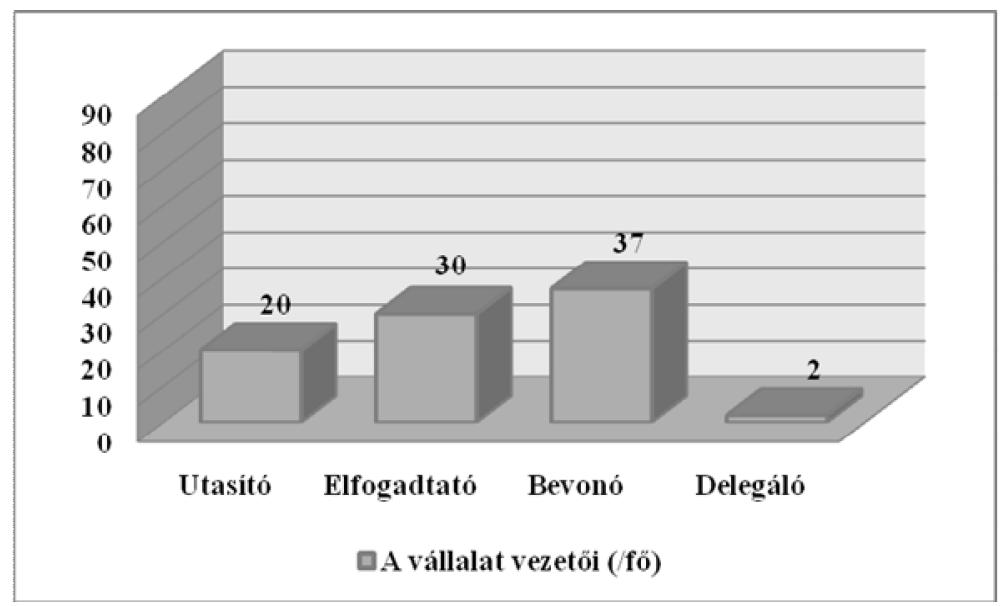

6. ábra: A vállalatra jellemző vezetési stílus (Forrás: saját adatbázis alapján)

Amint azt a 6. ábra is szemlélteti a vállalat vezetésére legmagasabb arányban a bevonó vezetés jellemző (37 fö). Ennek oka, hogy ezt a vezetési stílust általánosságban a középvezetők alkalmazzák, akik a legmagasabb arányban dolgoznak a vállalatnál a három vezetői szint közül. Az elfogadtató és az utasító vezetési stílus alkalmazása is magas értékeket kapott (30 és 20 fö), amely azzal magyarázható, hogy ezt a két vezetési stílust az operatív vezetők alkalmazzák, akik a középvezetőkhöz hasonlóan szintén magas arányban dolgoznak a vállalatnál. A delegáló stílusú vezetés 2 fö esetében jelenik meg, melyet a legkevesebb arányban jelen lévő felső vezetők alkalmaznak.

\section{Változási készség vizsgálata}

Napjainkban már a változás fontos szerepet kapott és az egyik legfontosabb sikertényező egy szervezetben. A változási készség egyik kiemelkedő jelentése, hogy milyen gyorsan és milyen mélységben tudunk alkalmazkodni az új helyzetekhez és ez mára egy igen fontos kulcstényezővé vált.

A változási készséget a vállalat vezető körében Mikulás Gábor (1999) Menedzsment címü könyvéből származó kérdőív segítségével vizsgáltuk. A kérdöívben különböző csoportokra bontva állításokat sorakoztat fel, amelyeket egy 5 fokozatú Likert-skálán kellett értékelniük a különböző szintű vezetőknek. A skálán az 1-es érték jelenti a soha, az 5-ös érték pedig a mindig kategóriákat. Az állításokat az alábbi szempontok szerint osztotta csoportokra: stratégia, struktúra, menedzsment stílus, közös értékek, a munkatársak tapasztalatai, készségei, szabályok és rendszerek. A kérdőív kiértékelésénél az adott válaszokat a Likert- 
skálán jelölt érték alapján pontszámokra váltottuk át. Az eredményeket tekintve minél magasabb az elért pontszám, annál sikeresebb a szervezet a változások tekintetében. A kérdőívben szereplő 31 kérdésre maximálisan 155 pont szerezhető és a 110-nél kevesebb eredmény arra utal, hogy a kategóriákhoz kapcsolódó bizonyos jellemzők, tulajdonságok közül több hiányzik az adott vezetői szinten.

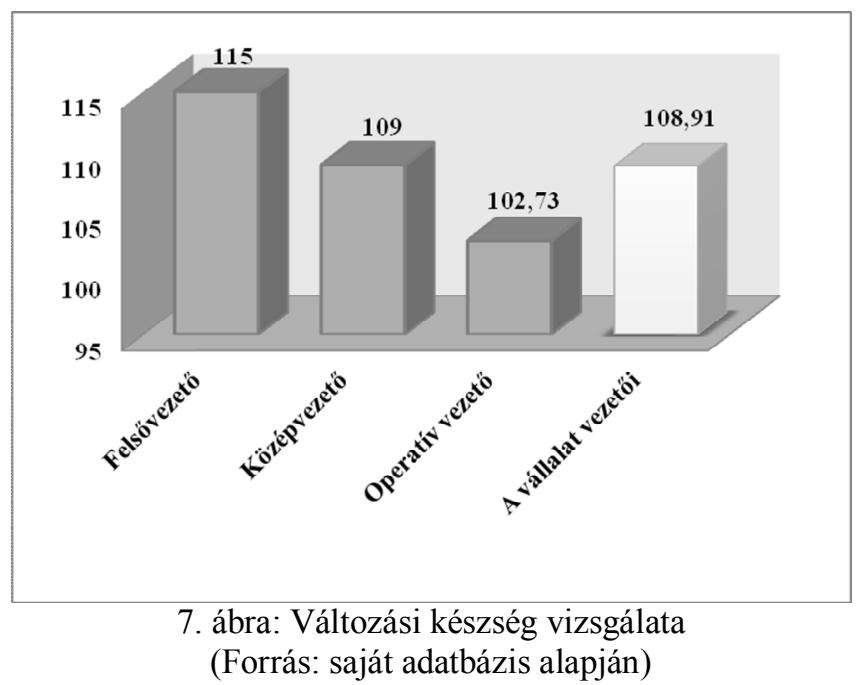

A 7. ábra alapján láthatjuk, hogy a legnagyobb hiányosságokkal az operatív vezetők rendelkeznek, melyet a 102,73-as átlagpontszám mutat. Összességében nézve a középvezetők 109 pontos értéke elfogadhatónak mondható. A felső vezetés 115-ös pontszáma megfelelő. A vállalat egészére vetítve az eredményeket a 108,91 -es érték elfogadható. A vállalat arra törekszik, hogy az összes vezetöi szint elérje a 110-es értéket. Átlagban minimális javítási potenciállal a 110-es érték gyorsan és hatékonyan elérhető.

\section{Konfliktuskezelés vizsgálata}

A vezetők konfliktuskezelési módjának vizsgálatához szintén kérdőívet használtunk (Mikulás, 1999). A kérdőívben állításpárokat sorakoztat fel, amelyek közül a teszt kitöltőjének a rá leginkább jellemzőt kellett kiválasztania. A teszt 30 megválaszolandó kérdésből áll. 


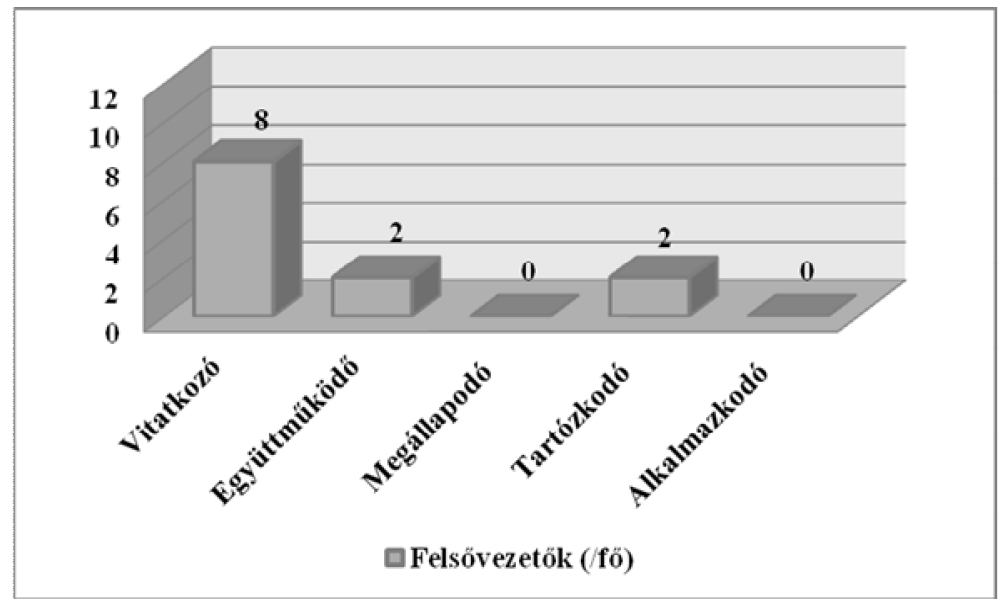

8. ábra: Felsővezetők konfliktuskezelési módja (Forrás: saját adatbázis alapján)

A 8. ábra alapján megállapítható, hogy a felső vezetés jelentős része a vitatkozó konfliktuskezelési módot részesíti előnyben (8fö). Ez azzal magyarázható, hogy a szervezet által képviselt értékek közé tartozik az, hogy a problémákat minél hatékonyabban tudják orvosolni. Ezt úgy érik el, hogy egy konfliktus felmerülése esetén az összes érintett fél véleményét, álláspontját kikérik és egyeztetik ezeket. A vezetők „megvitatják”, illetve „vitahelyzetet” teremtenek, hogy így jussanak el közösen a legkonstruktívabb megoldáshoz. Ez a fajta konfliktuskezelési mód szervesen hozzákapcsolódik a vállalati kultúrához, miszerint a dolgozók bevonása és véleményük értékelése által lehet igazán sikeres a szervezet.

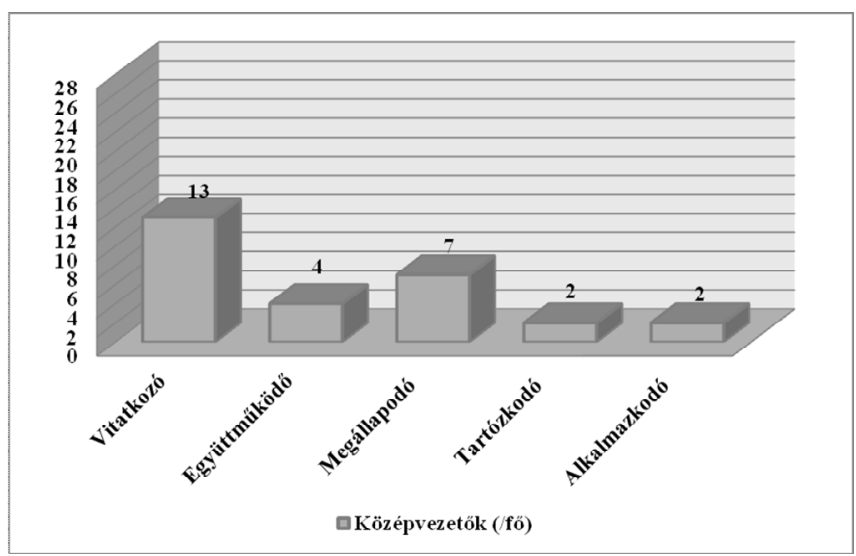

9. ábra: Középvezetők konfliktuskezelési módja

(Forrás: saját saját adatbázis alapján) 
A 9. ábrán láthajuk, hogy a középvezetők jelentős része, 13 fő a vitatkozó konfliktuskezelést alkalmazza, ami azt jelenti, hogy a felmerülő problémárkra a minél jobb és gyorsabb, célravezetőbb megoldást keresi. Az együttmüködő (4 fö) és a megállapodó stílus ( 7 fö) minimális számban a tartózkodó ( 2 fö) és az alkalmazkodó (2 fö) stílus is jelen van. A vitatkozó konfliktuskezelési módszer jó hatással lehet a szervezet egészére, hiszen elősegítheti a csoport céljainak elérését, bátorítja a kreativitást, motiválja az ötletek felszínre kerülését, a változást és az önértékelés szellemét viszi a csoportba.

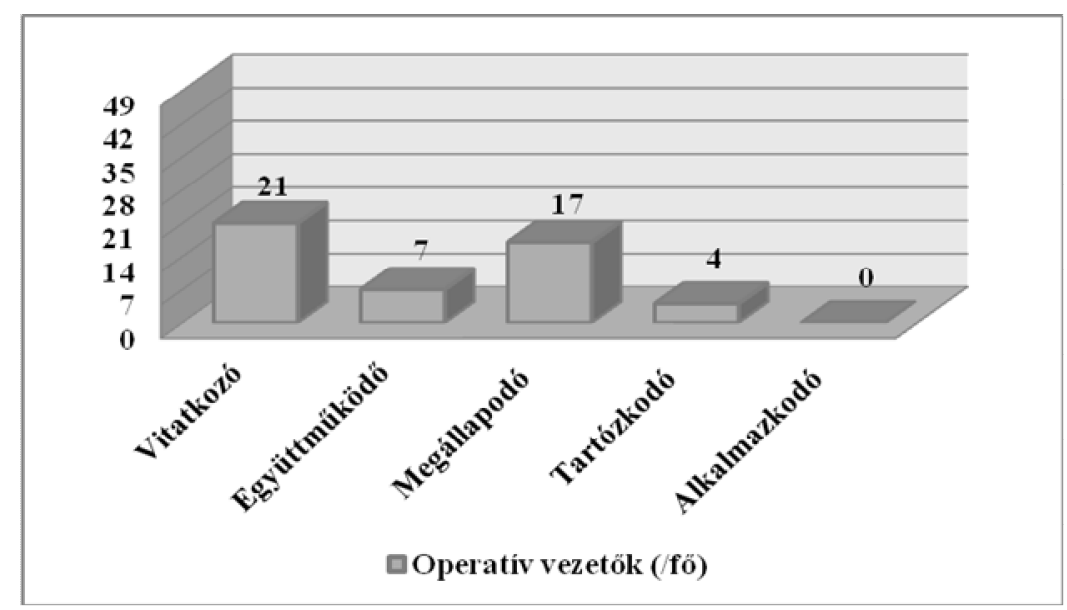

10. ábra: Operatív vezetők konfliktuskezelési módja (Forrás: saját adatbázis alapján)

A 10. ábrán láthatjuk, hogy az operatív vezetők esetében kiemelkedően magas értéket kapott a vitatkozó (21 fö) és a megállapodó (17fö) konfliktuskezelési mód. E mellett 7 főnél jelen van az együttmüködő és 4 fönél a tartózkodó stílus is. Ennek oka a vezetési stílusnál kapott eredményekhez hasonlóan az, hogy az operatív vezetők különböző szervezeti egységeket irányítanak illetve tartanak össze, amelyek különbözö konfliktuskezelési módokat kívánnak meg. Az alkalmazkodó konfliktuskezelési mód nem jellemző az operatív vezetőkre. 


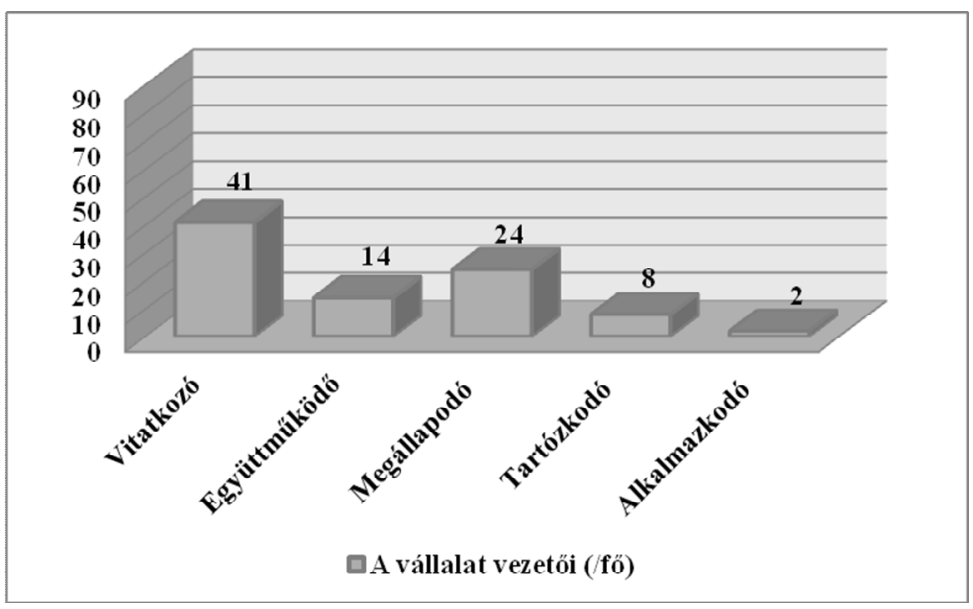

11.ábra: A vállalatra jellemző konfliktuskezelés (Forrás: saját adatbázis alapján)

Amint a 11. ábrán is láthatjuk, a vállalat vezetöire összességében a vitatkozó konfliktus kezelési mód jellemző (41 fö). E mellett magas értéket kapott a megállapodó (24 fö), az együttmüködő (14 fö), illetve a tartózkodó stílus (8fö). A cég filozófiájából fakad, hogy a konfliktuskezelés során az összes érintett fél véleményét, álláspontját kikérik. Ez által fejlesztik a szervezetet, hiszen elősegíthetik a célok elérését, serkentik a kerativitást, a motivációt és az önértékelés.

\section{KÖVETKEZTETÉSEK}

A kapott eredmények alapján következtetéseket és javaslatokat vonunk le és összefoglaltuk kutatási eredményeinket, melyeket tudományterületünkből adódóan külön fejeztben ismertetünk.

Kutatásunk során feltételeztük, hogy a felső, a közép és az operatív szintü vezetők azonos vezetési stílust alkalmaznak munkájuk során. A kapott eredmények alapján a három vezetői csoport részben alkalmazza ugyanazt a vezetői stílust, ugyanis a felső és a középvezetők a bevonó vezetést alkalmazzák, míg az operatív vezetők az elfogadtató és a bevonó vezetést egyaránt alkalmazzák. Ennek oka az, hogy a különböző munkacsoportok vezetői más és más szervezeti egységekben dolgozókat irányítanak. A különböző szervezeti egységek irányítása pedig különféle vezetöi stílust igényel.

A felső és középvezetők a bevonó vezetést alkalmazzák, ugyanis a sikeres müködéshez elengedhetetlen a dolgozók eredményes bevonása, amely a vezetés támogatása nélkül kudarcra van ítélve. 
Kutatásunk során vizsgáltuk, hogy a három szint vezetői milyen konfliktuskezelési módot alkalmaznak. A középvezetők, az operatív vezetők és a felsővezetők a vitatkozó konfliktuskezelési módot alkalmazzák munkájuk során, mert a rövid és hosszú távú célkitüzések eléréshez ők látják át a legjobban a szervezet hatékonyabbá tételét, annak érdekében, hogy az optimális eredményeket elérjék. A vezetőkben benne van a legjobbra törekvés, mely a konfliktuskezelés során is megnyilvánul, bár nem biztos, hogy ez a legjobb.

Megvizsgáltuk, hogy a három vezetői szint milyen mértékben tud alkalmazkodni a változásokhoz. Ez azonban csak részben teljesült. A hármas szintủ vezetők esetében azonban nagyon nagy hiányosságokat tárt fel a kutatás, ugyanis számos olyan tulajdonság fejlesztésre szorul, mely a hatékony munkavégzést segíti elő. A felső és a középvezetők a kapott értékek alapján jól tudnak alkalmazkodni a változásokhoz. Ez abból fakadhat, hogy a középvezetők és a felsővezetők módjuk és lehetőségük van külföldi tapasztalatok megszerzésére, ezért jobban tudnak alkalmazkodni a körülményekhez.

\section{JAVASLATOK}

A kapott eredmények tükrében számos lehetőség adódik a fejlesztésre. Javaslataink közé tartozik a vezetői készségfejlesztö tréningek tartása a vállalaton belül. A továbbképzések alkalmával lehetőség nyílna a vezetők számára, hogy vezetői csoportonként külön-külön, illetve az összes vezetői szint együttesen is megismerkedhessen a különféle vezető stílusokkal. Így minden stílusnak megismernék a pozitív és negatív oldalait, következményeit. Ezen ismeretek segítségével pedig lehetőségük nyílna egy olyan összetett vezetői stílus kialakítására, amely a vállalat által képviselt értékekhez illeszkedve a leghatékonyabb irányítást tenné lehetővé mind a felsővezetöi szinten, mind pedig az alsóbb vezetői szinteken egyaránt.

A konfliktuskezelési készségek fejlesztésére workshopok megszervezését javasolnánk a vállalat számára. A wokshopok alkalmával egy adott szakterület iránt érdeklődő emberek közös munkával valami újat - általában szellemi terméket - hoznak létre az adott témában. A workshop az adott témára létrehozott munkacsoportban zajlik és tevékenysége egy adott kérdés vagy probléma interaktív elemzésére és megoldási javaslatok kidolgozására irányul, többnyire kreatív technikák segítségével. Ilyen workshopok alkalmával a résztvevők megismerhetnék a konfliktusok létrejöttének mechanizmusait, ami által képesek lennének céltudatosan viselkedni konfliktushelyzetben és gyarapítani a konfliktusok feloldását szolgáló eszköztárukat. Illetve a vezetők a beosztottakkal együttmüködve szintén elsajátíthatnának új konfliktuskezelési technikákat. 
A változási készség javítása érdekében a különböző munkacsoportok vezetőinek további vizsgálataival, illetve nagyobb számú részvételi aránnyal megállapíthatóvá válna a hiányosságok pontos forrása, illetve ha nem, vezetői szintre vonatkoztatva történne a vizsgálat, hanem területre felosztva a probléma hatékony megvilágítása és felmérése nagyban növelné a hatékonyságot és hozzájárulna a megfelelő a javítási potenciál megtalálásához.

A hármas szintü vezetők változási készségének másik fejlesztési módja az lehetne, ha ők is el tudnának egy bizonyos időt tölteni az anyavállalatnál (külföldön), illetve orientációs képzéseken vennének részt és más emberekkel, nemzetiségekkel együtt dolgozva új ismeretekre és tapasztalatokra tegyenek/tennének szert.

Javaslataink közé tartozik továbbá a coaching tevékenység bevezetése a vállalatnál. A coach olyan személy, aki a különböző szinteken lévő vezetőknek segíti a munkáját. Általában a vezetők további fejlődése érdekében alkalmaznak coachot, hogy a munkafolyamatok együttes átbeszélése során felhívja a figyelmet az elhamarkodott következtetésekre, hibás viselkedésmódokra, feltárva azok hátterét, lehetőség szerint megszüntesse a kiváltó okokat. A coaching az alábbi területeken nyújthat segítséget: a megfelelö vezetési stílus megválasztása, a hatékony delegálás, munkamegosztás, a döntés-előkészítés, döntéshozás, konfliktuskezelés, kommunikációs zavarok elhárítása, motivációs problémák kezelése, irányítási problémák és stratégiai dilemmák esetén.

\section{ÖSSZEFOGLALÁS}

A kialakult gazdasági helyzet és a kiéleződött versenyhelyzet következtében a vezetés szerepe napjainkra felértékelődött. A vezető hozzáállásával, példamutatásával és a célokért való elkötelezettség révén járul hozzá a sikeres müködéshez.

Kutatásunk célja az volt, hogy megvizsgáljuk egy ma Magyarországon sikeresen müködő multinacionális cég esetében a vezetés milyen vezetői stílust alkalmaz a hatékony és eredményes munkavégzés érdekében. Emellett a külső környezet dinamikus változásai által jelentkező adaptációs kihívásra a vállalat vezetői hogyan reagálnak, azaz milyen a változási készségük. A kiélezett versenyhelyzet kapcsán a szervezetekben a konfliktus gyakori jelenség és ennek kezelése komoly próbatétel a legkiválóbb szakemberek számára is.

Kutatásunk célja az volt, hogy a cégen belül a vezetés három szintjének vezetési stílusát, változási készségét és konfliktuskezelési módját megvizsgáljuk. Kutatásunk során számos célt tüztünk ki, melyeket leíró statisztika segítségével vizsgáltunk meg.

A vezetési stílus tekintetében a felső és középvezetők ugyanazt a stílust, a bevonó vezetést alkalmazzák, míg az operatív vezetők az elfogadtató és az utasí- 
tó stílust is alkalmazzák munkájuk során. A részvétre épülő vezetési stílus a vállalat számára a legelőnyösebb, mert a csoportmunkát, a fejlesztések támogatását, a rugalmasságot, az iránymutatást és a célkitüzést helyezik előtérbe. Az alkalmazott vezetési stílus függ az irányított dolgozóktól is. A felső vezetésnek nincs szüksége az utasító stílusra, hiszen ők már összeszokott munkacsoportokkal dolgoznak. Az operatív vezetők esetében viszont a bevonó vezetés nem alkalmazható, ugyanis ők kezdő, kevéssé tapasztalt dolgozókat irányítanak.

A kapott eredmények alapján megállapíthatjuk, hogy a feltételezésünk, miszerint a változási készség tekintetében minden vezetési stílus ugyanolyan mértékben képes alkalmazkodni, csak részben teljesült. Az operatív vezetők ennél a készségnél hátrányban vannak a többi szinthez képest, amit a vállalatnak orvosolnia kell.

Konfliktuskezelés tekintetében a vállalat vezetői a vitatkozó kategóriába tartoznak. Ez azzal magyarázható, hogy a vezetők a legjobbra törekednek, annak érdekében, hogy a szervezet minél eredményesebben és hatékonyabban müködhessen.

\section{Irodalomjegyzék}

1. Bakacsi Gyula. (2004): Szervezeti magatartás és vezetés Aula Kiadó Kft. Budapesti CORVINUS Egyetem (ISBN 963958549 1)

2. Balogh Éva (2000): Pszichológiai kislexikon, Tóth Könyvkereskedés és Kiadó Kft., Debrecen, 188.p

3. FN24, (2011) Helyzetfüggő vezetési stílusok: http://fn.hir24.hu/karrier/2007/09/28/helyzettol_fuggo_vezetesi_stilusok (letöltve: 2013.10.05 20:22)

4. Ford, R. C. - Fottler, M. D. (1995): Empowerment: A matter of degree. Academy of Managerment Executive, 21-32. p.

5. Gyökér I. (2006): Szervezeti viselkedés (oktatási segédanyag, Budapesti Müszaki Egyetem), Budapest

6. Karácsonyi András (2006): A leadership, a szervezeti kultúra és kapcsolatuk jellegzetességei a magyar szervezetek esetében, $9 \mathrm{p}$.

7. Mikulás Gábor (1999): Menedzsment, Szabolcs - Szatmár - Bereg Megyei Könyvtárak Egyesülés Nyíregyháza (1999), (ISBN:963 037288 6)

8. Poór F. (2013), Legyünk ,jóban” a konfliktussal, http://www.hrportal.hu/hr/legyunk-joban-a-konfliktusokkal-20130823.html (letöltve: 2013.11.08 19:33) 
9. Vezetés-vezetők honlap - szerző nélkül (2009): A változások vezetése (menedzselése).

http://www.vezetes-vezetok.hu/index.php/valtozasok-vezetese.html (letöltve: 2013.10.16. 19:40)

10. Zrinszky László (1985): Íratlan szabályok, Kossuth Könyvkiadó, Budapest, 117-126. p

Sipos Gábor: müszaki menedzser szakos (BSc) hallgató

Debreceni Egyetem Müszaki Kar Müszaki Menedzsment és Vállalkozási Tanszék, 4028 Debrecen, Ótemető u. 2-4.

Szücs Edit: főiskolai tanár

Debreceni Egyetem Müszaki Kar Müszaki Menedzsment és Vállalkozási Tanszék, 4028 Debrecen, Ótemető u. 2-4.

Takács Tímea: müszaki menedzser szakos (MSc) hallgató

Debreceni Egyetem Müszaki Kar Müszaki Menedzsment és Vállalkozási Tanszék, 4028 Debrecen, Ótemető u. 2-4.

Matkó Andrea: föiskolai adjunktus

Debreceni Egyetem Müszaki Kar Müszaki Menedzsment és Vállalkozási Tanszék, 4028 Debrecen, Ótemető u. 2-4. 


\section{UNIVERSITY \\ of DEBRECEN \\ FACULTY OF \\ HEALTH}

NYÍREGYHÁZA

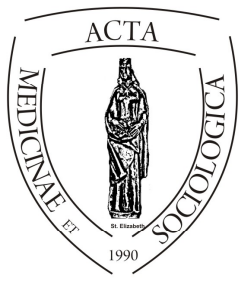

ACTA

MedSoc

VOLUME 5.

2014

\title{
A vállalati elit és a kapcsolati tőke viszonyának elemzése
}

\author{
Makszim Györgyné \\ Nyíregyházi Főiskola, Gazdálkodástudományi Intézet
}

\begin{abstract}
Összefoglalás: A vállalati elit, mint szociológiai fogalom vizsgálata nehezen képzelhetö el a csoportképzésben szerepet játszó befolyásoló tényezők ismerete és vizsgálata nélkül. Jelen tanulmányban a befolyásoló tényezők közül a ma már önálló erőforrást képező kapcsolati tőke szerepét kívánom kiemelni, melynek hatása nem közvetlenül érvényesül, azonban mégis jelentős, éppen ezért tekintem külön vizsgálati terepnek. A kapcsolati tőke hatása már csak azért is közvetett, mert nemcsak egy szociológiai csoport ('́gy a vállalati elit) jellemzésében játszik szerepet, hanem a gazdasági élet „föszereplöin” (a vállalkozókon) keresztül, a vállalkozói szféra által fejti ki hatását a gazdasági, társadalmi folyamatokra.
\end{abstract}

\begin{abstract}
Networking capital - as a resource becoming gradually more and more valuable and becoming a resource on its own - can be linked to the existence, limits and even the internal structure of a company. The essence of a company can be the efficient organisation of networking capital. The concept of networking capital has a rather complex content, thus even today we cannot speak about a single definition. There are several approaches, most of which regard networking capital as a partial alternative of social capital.

My theory gives a more significant role to the entrepreneur in obtaining and coordinating networking capital. These jointly suppose dynamic environment. Basically networking capital may explain efficiency issues and challenges of the economic changes of the environment.

The results of the empirical research show that in most cases there is a significant connection between the structural characteristics of the enterprises and the networking
\end{abstract}


capital; the direction and the magnitude of the impacts can be determined and measured by appropriate statistical tests and analytical methods.

Keywords: networking capital, enterprise elit, company, entrepreneur, structural characteristics of the enterprises, empirical research, probability connection, questionnaire survey, sample

\section{A témaválasztás indoklása}

A témaválasztásban egyértelmüen közgazdasági végzettségem, illetve az ezen a területen folytatott tudományos tevékenységem játszott motiváló szerepet. Jelenleg ugyanis a „Vállalatelmélet és Gyakorlat Doktori Iskola” (ME-GTK) PhD hallgatója vagyok, kutatási témám: Szabolcs-Szatmár-Bereg megye vállalkozási szerkezetének statisztikai elemzése, illetve a gazdasági folyamatok és a vállalkozási jellemzők közötti összefüggések vizsgálata. E téma utolsó összetevője (,vállalkozási jellemzők”) adta meg a lehetőségét, hogy a vállalati elitet a kapcsolati tőke összefüggésében vizsgáljam. A vállalati jellemzők között ugyanis már kutatásaim kezdetén kitüntetett szerepet szántam a kapcsolati tőkének, melyet érintőlegesen empirikus úton (kérdőíves felmérés keretében) is teszteltem.

Jelen téma megválasztásában persze tudományos munkám mellett, a vállalkozások és a szociológia iránti érdeklődésem is motivált. Ráadásul úgy gondolom, hogy a vállalkozások és vállalatvezetők szociológiai szempontú vizsgálata napjainkban is igen aktuális és időszerü, hiszen éppen a kapcsolati tőke vállalkozásokra gyakorolt hatásának egyre meghatározóbb jellege, mindig tartogat újabb és újabb nyitva hagyott kérdéseket, vizsgálati területeket.

\section{A téma aktualitása, módszertan}

A gazdasági folyamatok alakításában fontos szerepet töltenek be a vállalkozások. A vállalati szféra, azon belül pedig a vállalati elit és a kapcsolati tőke gazdasági, szociológiai szempontú vizsgálata hatással lehet mind a gazdasági fejlödést meghatározó tényezőkre, mind pedig a vállalkozási szerkezetben fellépő problémák kezelésére.

A vállalati elit jellemzőinek feltérképezése, a vállalati elit jellemzői és a gazdasági folyamatok közötti sztochasztikus kapcsolatok elemzése minden időben aktuális a gazdaság egyes szereplőinek, a gazdaság-politika irányvonalát meghatározó szereplőknek, de a téma iránt érdeklődőknek egyaránt. 
Az elemzés során számos hazai és nemzetközi szakirodalom áttekintését végeztem el. Emellett egy általam készített empirikus kutatás (Makszim 2010) is a tanulmány alapjául szolgál. A kvantitatív kutatással kapcsolatban mindenképpen ki szeretném emelni, hogy a mintavétel alapsokaságát képező vállalkozásokat a KSH céginformációs adattárából szürtem le és hoztam létre a kutatás alapsokaságához hozzárendelhető mintavételi keretet.

A kutatás mintavételi technikájának megválasztásakor reprezentativitásra törekedtem. A felmérés során szisztematikus mintavételt alkalmazva 250 vállalkozást, pontosabban vállalatvezetőt kérdeztünk meg személyesen SzabolcsSzatmár-Bereg megye területéről. (A vállalati megkérdezés költségvetési kerete nem tett lehetővé nagyobb mintanagyságot.) Szisztematikus kiválasztás esetén a populáció tagjait bizonyos rendben rögzítjük, és az egyenlő távolságban álló egyedeket választjuk ki (névsor, lajstrom, időközök stb. alapján). Elméletileg ez akkor tekinthető véletlen (valószínüségi) kiválasztásnak, ha a populáció egyedeinek sorba rendezése véletlenszerüen történik (Hunyadi-Mundruczó-Vita 2001 és Falus-Ollé 2008). A felmérés kapcsán ezt úgy biztosítottam, hogy a KSH $\mathrm{ABC}$ sorrendben rögzített - céginformációs adattárából minden 50 . vállalkozást választottam ki. Az információgyüjtés kérdöívvel támogatott, telefonos megkérdezés formájában zajlott, amelyet gyakorlott és erre a célra külön felkészített kérdezőbiztosok végeztek. Az információgyüjtés ideje (2010. június-július) két hónapot vett igénybe négy kérdezőbiztos (köztük jómagam) közremüködésével. A vállalati kérdőívet a 3. számú melléklet tartalmazza. A kérdőív célja az volt, hogy feltérképezze Szabolcs-Szatmár-Bereg megye vállalkozásainak szerkezeti jellemzőit, azok összefüggéseit, illetve gazdasági-társadalmi folyamatokat érintő kapcsolódásait.

A kérdőív egyes kérdései a vállalatok alapadataira vonatkoztak, egy jelentős részük viszont a vállalat tulajdonosainak (vezetőinek) véleményét szerette volna feltárni. Ez utóbbihoz Likert skálát is alkalmaztunk, ahol a válaszadóknak 1-től 5-ig terjedő skálán kellett véleményüket megfogalmazni. Ez utóbbi kérdések föként szubjektív vélemény felderítésére vállalkoztak, ezt a tényt a kapott eredmények értékelésekor figyelembe kell venni. A kérdőívet a kitöltés elött több ízben teszteltem.

A minta megbízhatósági szintje: 95\%, pontossági szintje pedig 6,2 százalékpont, a minta nagysága 250 vállalkozás.

A statisztikai számításokhoz a Windows alapú SPSS 19.0 statisztikai programcsomagot használtam fel. 


\section{Elméleti áttekintés}

Annak érdekében, hogy a jelen tanulmányban megfogalmazott alapvető fogalmak alatt mindenki ugyanazt értse, elengedhetetlen a konceptualizálás, vagyis a kulcsszavak pontos, szabatos definiálása. A témához kapcsolódó szakirodalom oly mértékben szerteágazó és széleskörü, hogy az esszé kereteit lényegesen meghaladó feladat lenne valamennyi területét, akárcsak érintőlegesen is bemutatni. Erre a feladatra nem is vállalkoztam, sokkal inkább a téma fogalmi kereteit biztosító elit, vállalkozó és kapcsolati tőke fogalmak meghatározására, különböző ismérvek szerinti rendszerezésére, csoportosítására. Az irodalomelemzés forrásául a témakör meghatározó és méltán elismert nemzetközi és hazai szakkönyvei, folyóiratokban megjelent szakcikkei és egyéb tudományos művek szolgáltak.

\section{A vállalati elit fogalma}

Az ,elit”, mint társadalmi csoport megjelölésére használt fogalom először a fönemességre és a hadsereg különleges osztagaira vonatkozott. Társadalom- és politikatudományi használata a 19. századtól jellemző, elsősorban Pareto elitszociológiai elmélete nyomán. Pareto munkássága nem áll távol sem a szociológiától, sem pedig a közgazdaságtudományoktól, így - mivel e két tudományterület jelen tanulmányban is összekapcsolódik - számomra ő jelent egyfajta kiindulópontot a módszertani alapok területén.

Pareto társadalmi elitértelmezése összefügg a szó eredeti jelentéstartalmával: nemcsak az áruk között vannak kiválóak, hanem az emberek között is. Ezek körét egzakt módon, úgy határozta meg, hogy minden ember tevékenységéhez egy indexet rendelt. Az elit osztályát pedig azokból alakította ki, akiknek a legmagasabb indexszámuk van az adott ágazatban (Pareto 1972). Ennek eredményeképpen két részre bontotta ezt az osztályt:

- kormányzó elit: akik közvetlen vagy közvetett módon jelentős szerepet játszanak a kormányzásban, így például a miniszter, a szenátor, a bírósági elnök, az ezredes stb.; a többiek pedig a

- nem kormányzó elitet képezik.

Ma már úgy gondolom, problémás lenne a vállalatvezetők egyetlen index alapján történő minősítése, mivel nehéz pontosan behatárolni azokat az ismérveket, amelyek a jó vezető kritériumaként szolgálhatnak. A minősítés alapjául szolgáló változók száma nem is határozható meg pontosan, számuk fokozatosan bővül, tartalmilag átalakul, ráadásul egyre több változó bevonása egy elméleti indexbe egyre kevésbé teszi lehetővé az általános következtetések levonását. Emellett 
persze Pareto jelentősége vitathatatlan az elitkutatásokban, így többek között nagy hatással volt a neoelitista irányzatok közül Lasswell munkásságára, aki Paretohoz hasonlóan értelmezte az elit fogalmát: azok a személyek, akik az értékből a legtöbbet tudhatnak magukénak (Lasswell 1934). Később az elit fogalmát ő már kizárólag a politikai elittel azonosította, és eltekintett annak gazdasági, társadalmi vetületeitől.

A 20. század közepétől a politikai elit mellett fokozatosan megjelent a gazdasági elit fogalma, amely a gazdasági hatalomhoz, a gazdasági pozíciókhoz vagy a gazdasági életben megnyilvánuló különleges karaktervonásokhoz köthető. Szükebb értelmezésben a gazdasági elit csupán a nagyvállalatok vezetőit képezi (Róna-Tas-Böröcz 1997). Ezt a szükebb értelmezést vettem alapul a tanulmányban megjelenő empirikus kutatás során is, hiszen a kérdőív egyes kérdései kifejezetten vállalatvezetőkhöz lettek címezve, és ők maguk adtak választ rájuk.

A gazdasági elit fogalma kapcsán elsősorban James Burnham (1965) munkásságát kell kiemelni, aki a „menedzserek forradalmának” elméletében e fogalom részletes tartalmát tárta fel. Burnham megkülönbözteti a kapitalista és a menedzseri társadalmat. Ez utóbbiban már nem a tulajdonosok, hanem a menedzserek irányítják és ellenőrzik a termelést. A „menedzserek forradalma” kifejezés arra utal, hogy a gazdasági döntéshozók köre változott meg. Burnham ugyanakkor a gazdasági elit vizsgálatakor a személyes jellemvonások jelentőségére irányítja a figyelmet. A menedzsereket két csoportra osztja: egyrészt a tudósok és technokraták csoportjára, másrészt a vezetőkre és a termelési folyamat koordinátoraira. Mindkét csoportba olyan személyek fognak kerülni, akik alkalmasak az adott feladatra, tehát a gazdaság önmaga termeli ki a saját elitjét. Így a személyes jellemvonásaik és képességeik alapján legmegfelelőbb emberek kerülnek a fö gazdasági döntéshozói pozíciókba.

Jelen tanulmányban a menedzseri társadalom csak szük körben jelenik meg, hiszen a menedzser réteg a nagy-, vagy esetleg a középvállalatokhoz kötődik, míg az általam végzett kutatásban a mikro-és kisvállalkozások dominálnak, melyekben jellemzően a tulajdonos egyben a vállalat vezetője is. A magyar vállalati szférában egyébként még mindig igen szük réteget képeznek a menedzserek, melynek egyértelmüen a tőkeszegénység az oka, ami által nem tud kialakulni egy szélesebb nagyvállalati kör, ezáltal egy versenyző menedzser réteg.

Bendix és Howton (1967) felsorolja a gazdasági elit fogalomkörét betöltő személy legfontosabb karakterjegyeit: a presztízs, a jövedelem, a társadalmi és politikai befolyás, az adott cég nagysága és sikeressége, a kapcsolatháló kiterjedtsége, az alárendeltek száma, a civil szférában kifejtett aktivitás stb. A felsorolásból kitünik, hogy már e szerzőpáros is fontosnak tartotta a kapcsolati tőke, „kapcsolati háló” szerepét a gazdasági elit értelmezésében. A jellemzők sokasága azonban nem teszi lehetővé az általánosítható következtetések levonását. 
Bourdieu (1998) definíciója az elitről már konkrétabb, melynek meghatározásakor tőkeelméleteiből indul ki, és azt mondja, hogy azok tartoznak a társadalom domináns csoportjaiba, akik a legtöbb tőkefajtával rendelkeznek. A tőkének több fajtáját különböztette meg: szociális, gazdasági, társadalmi és kulturális tőkét. Bourdieu munkássága tehát rendkívül közel áll dolgozatom témájához, hiszen elméleteiben szintén összekapcsolódik az elit és a kapcsolati tőke, pontosabban utóbbi nála még társadalmi tőke.

Hasonlóan közelálló módszertani alapokat nyújtott Róna-Tas Ákos és Böröcz József (1997) megközelítése is, akik abból az elméleti állításból indultak ki, hogy a gazdasági elitek kialakulását mind az államszocialista időszakban, mind pedig az azt megelőző korban gyökerező gondolkodásmód, szaktudás és kapcsolatrendszer befolyásolja. Ezek a társadalmi jellemzők tipikusan az egyes egyénhez tapadó, nagy tehetetlenségü erőforrások. A mentalitás, a szaktudás és a kapcsolatrendszer azért tapadósak, mert nem könnyü megszabadulni tölük vagy másoknak átadni őket. Még nehezebb erőszakkal elvenni őket az emberektől. Ezeket a nem anyagi jellegü erőforrásokat kizárólag az őket birtokló egyének képesek megváltoztatni. Ezt a jelenséget elméletükben az individuum oszthatatlanságának nevezik. Minden embernek megvan a maga mentalitása, szaktudása és kapcsolatrendszere, és nagyon nehéz megváltoztatni ezeket a jellemzőket, mert kialakulásukat egy egész életpálya határozza meg. Ebből következik, hogy ezeknek az adottságoknak az ereje az idő függvénye, s így hosszú idő kell a kialakulásukhoz, de éppen ezért a megváltoztatásuk is igen nehéz. Az intézményi és a társadalmi változásban betöltött szerepük megértéséhez nem elég a személyes adottságok önmagában való vizsgálata, hanem azt is fel kell tárni, hogy hogyan alakulnak ki és változnak meg ezek az adottságok, és milyen hatással vannak a gazdasági és társadalmi folyamatokra. Kutatásomat elsősorban ez utóbbi (Róna-Tas és Böröcz 1997) elméleti megközelítésre építettem, ezt a gondolatmenetet próbáltam meg továbbvinni, és igazolni empirikus adatok és elemzések segítségével.

\section{A vállalkozó, mint a vállalati elit meghatározó személye}

Hasonlóan sokszínú a vállalkozó fogalmi lehatárolása is, melynek egyik korai definícióját Cantillon adta a XVIII. század elején, aki mint racionális döntéshozót jellemezte a vállalkozót, aki kockázatot vállal és menedzsmentet biztosít az üzlet számára. A kereslet és a kínálat egyensúlytalanságából adódó lehetőségeket kihasználva célja a profitszerzés. A középkori vállalkozó-felfogással szemben, amikor is a vállalkozó csupán a nagy termelőmunkák irányításáert felelt, Cantillon korai vállalkozó elméletében központi szerepet kapott a kockázatvállalás (Herbert és Link 1982).

A XVIII. század folyamán kitágult a vállalkozó értelmezése, melynek következtében elkülönült egymástól a kockázatot viselő személy és a tőkét biztosító személy, megteremtve ezzel a kockázati tőkés fogalmát. A XIX. század végén a 
vállalkozó és a menedzser személye szorosan összefonódott, a vállalkozó az erőforrások hatékony müködtetőjeként jelent meg, aki nyereség elérésére törekszik. Ahogyan arra már korábban is utaltam jelen tanulmány kérdőíves felmérése is döntö mértékben olyan vállalkozásokat tartalmaz, ahol a tulajdonos egyben menedzser is. A mikro- és kisvállalkozások ugyanis nem engedhetik meg maguknak, hogy e két szerep külön váljon.

A XX. század közepétől az újítás jelent meg a vállalkozás alapvető jellemzöjeként (Schumpeter 1980). A vállalkozó, mint újító fogalom összefonódott Schumpeter munkásságával, aki mellesleg a közgazdaságtan és a statisztika területén egyaránt otthonosan mozgott. Míg Cantillonnál a vállalkozó kihasználja az egyensúlytalanságból adódó lehetőségeket, addig Schumpeternél maga a vállalkozó egy aktív, egyensúlytalanságot teremtő erö, aki mint kiváló innovátor változásokat vezet be, lerombolja a fennálló egyensúlyi helyzetet. Így Schumpeter felfogásában a vállalkozás szorosan összekapcsolódik a gazdasági növekedéssel. Vállalkozó definíciójában viszont - sokakkal ellentétben - ő nem emeli ki a kockázatvállalási szerepet. Schumpeternél tehát az újitás áll a középpontban, elősegítve ezzel a gazdaság fejlődését.

A schumpeteri vállalkozó fogalmához áll közel a következő megközelítés is: szükebb értelemben vállalkozónak tekintjük azokat, akik vállalkozásuk során saját vagyonukat kockáztatva aktív szerepet játszanak az üzletmenet irányításában. A menedzserek, vállalatvezetők ugyan fontos szereplői a vállalkozásoknak, de nem vállalkozók, amennyiben befektetett vagyonukkal nem viselik a döntések kockázatát (Kállay et al. 2004). E definíció alapján leginkább csak az önfoglalkoztatók, a mikrovállalkozások férnének bele a vállalkozó fogalmába. Ez a megközelítés így nem alkalmazható egységesen a vállalkozó fogalmára.

Hisrich és Peters (1991) szerint a vállalkozó eredetileg „közvetítő" vagy „kapcsolatteremtőt” jelent. Vecsenyei (2002) így ír a vállalkozóról: „az a személy, aki a káoszban felismeri a lehetőséget, aki a semmiből akar létrehozni valami értéket, aki egyedül vagy másokkal együttmüködve valósítja meg termékben, szolgáltatásban, szervezetben megnyilvánuló elképzeléseit.” Az általam használt vállalkozó fogalma Hisrich és Peters, illetve Vecsenyei értelmezéséhez áll a legközelebb, hiszen mindegyikük kiemeli a kapcsolat, az együttmüködés jelentőségét a vállalkozó meghatározása során. Véleményem szerint a vállalkozó értelmezhető úgy is, mint aki a vállalati szerkezeti jellemzőknek és a területi fejlődést meghatározó gazdasági-társadalmi folyamatoknak egymással összefüggő és egymással kapcsolatban lévő rendszerét koordinálja.

A vállalkozó fogalmát még aprólékosabban elemezhetjük, ha bevonjuk a vizsgálatba a gazdasági jellemzők mellett a nem gazdasági a személyiségjegyeket is. Sokak szerint vállalkozónak születni kell, mások szerint ez is, csakúgy, mint sok más dolog az életben tanulható. 
A vállalkozó nem gazdasági magyarázatára először Max Weber tett kísérletet, összekapcsolva a modern kapitalizmus fejlődését a „protestáns erkölcs” terjesztésével. Véleménye szerint a vállalkozói jellemvonások külső eredetü vallásos hiedelmek hatására jönnek létre (Fülöp 2004).

Kilby (1971) mutat rá arra, hogy a pszichológiai elméletek feltételezik, hogy a vállalkozók veleszületett személyiségjegyekkel jellemezhetők, és sajátos motivációkkal rendelkeznek. A sikeres vállalkozókra önbizalom, tudatosság, reális környezetszemlélet, kiváló koncepcióalkotó képesség, jó kapcsolatteremtő képesség, jó egészségi állapot jellemző. A vállalkozók fontos jellemvonásai még a belső energia, a személyes varázs, az önuralom a jó kommunikációs készség. Az eddig említetteken túl számos szerzőnél olyan jellemzők is megjelennek, mint az érzelmi stabilitás, az önfeláldozás vagy a munkájuk iránti megszállottság (Bygreve 1997).

Fülöp és Szegedi (Fülöp 2004) kutatásai alapján megállapítható, hogy a vállalkozási tevékenységek, illetve döntéssorozat középpontjában leginkább az öröklött készségek, a fejleszthető képességek és a megmaradt ismeretek állnak.

A kutatás súlypontja az utóbbi időben egyértelmúen a vállalkozó és a gazdasági fejlődés összefüggéseinek feltárására, valamint a vállalkozó nem gazdasági (elsősorban szociológiai, pszichológiai) szempontú jellemzőinek vizsgálatára tevődött át. Az új irányvonalak között (Nijkamp, Capello, Florida) megjelenik az általam is elemzett kapcsolati tőke hatásainak elemzése a vállalati szférában, valamint a gazdasági, társadalmi folyamatokban. Ezek részletes feltárása jövőbeli kutatási céljaim között szerepel.

A vállalkozókat több szempont szerint csoportosíthatjuk, melyek közül a legjellemzőbbeket az 1. számú melléklet emeli ki.

\section{A kapcsolati tőke fogalmi lehatárolása}

A kapcsolati tőke fogalma meglehetősen összetett tartalommal bír, így egységes definiálásáról máig sem beszélhetünk. Többféle megközelítés létezik, melyek döntő része a kapcsolati tőkét a társadalmi tőke részleges alternatívájának tekinti (ld. Putman, Coleman, Bourdieu, Fukuyama, Lin, Burt). A társadalmi tőke olyan magánvagyon, amely erősítheti az érintettek társadalmi státusát, hatalmát (Bourdieu, 1998).

A kapcsolati tőke tartalmát tekintve megfelel a tőke közgazdaságtani definíciójának, hiszen a kapcsolati tőke alkalmas termékek és szolgáltatások létrehozására, miközben maga nem alakul át, illetve a kapcsolati tőke előállításához a majdani haszon reményében áldozatot kell hozni.

A kapcsolati tőke Becker (1996) elméletében az egyéni haszonmaximalizálás tárgya.

Bosma (2002) érvelésének lényege az, hogy a kapcsolati tőke az emberi tőkéhez hasonlóan szignifikánsan növeli a vállalkozás teljesítményét és a vállalko- 
zás sikerének esélyét. Egyfelől, mert a jobban müködő szervezet növeli a munkaerő termelékenységét, másfelöl a jelzés-hatás miatt, vagyis a több emberi és kapcsolati tőke jó képet fest a cégről, annak potenciális teljesítményéről, a cégről keveset tudó gazdasági szereplők számára.

Hofferth és társai (1999) szerint akkor beszélhetünk kapcsolati tőkéről, ha a korábbi beruházások és a későbbi profit között erős és pozitív összefüggés mutatható ki.

Lin (2001) szerint a kapcsolati tőke olcsóbbá és megbízhatóbbá teszi az információ-áramlást, csökkenti a vállalatok megkeresésének tranzakciós költségeit, növeli a vállalatok hírnevét, önbizalmát.

Fafchamps és Minten (2002) szerint a tökéletlenül müködő piac feltételei között a kapcsolati tőke hasznossága azt jelenti, hogy mások ismeretéből haszna származik a vállalkozónak. A kapcsolatok segíthetik a vállalkozót abban, hogy

- olcsó és megbízható információhoz jusson,

- a másokkal kötött megállapodásai teljesüljenek,

- a kapcsolati tőke a kartellképzés, az oligopólium létrehozásának is lehet eszköze.

Galasi (1994) szerint a kapcsolati tőke a vevőkkel, ügyfelekkel illetve egyéb külső partnerekkel kialakított kapcsolatokat tartalmazza. A kapcsolati tőke a szervezet sajátja, bár a szervezet tagjai hozzák létre, de ezek hosszú időn keresztül fennmaradnak és személyfüggetlenné válnak. A kapcsolati tőke helyét a vállalkozások tőkerendszerében az 2. számú melléklet mutatja be.

A Galasi-féle vállalati tőkestruktúrát azzal a megállapítással szeretném kiegészíteni, hogy a pénzügyi és az intellektuális tőke mellett a fizikai tőke is ugyanolyan fontossággal bír, így ez utóbbi elem is a vállalati tökeállomány önálló elemeként értelmezhető.

Látható, hogy a kapcsolati tőkét nem lehet egyértelmüen definiálni, nincs is egységes fogalma. Ez azonban nem feltétlenül probléma, hiszen a kapcsolati tőke egy rendkívül összetett jelenség, és valójában valamennyi előbb említett meghatározás része e fogalom komplex értelmezésének. Éppen ezért nem mondhatjuk egyik vagy másik meghatározásra, hogy jó vagy rossz, helyes vagy helytelen, hanem célszerü valamennyi megközelítést figyelembe venni, és komplexen, az aktuális gazdasági, társadalmi jelenségek tükrében elemezni a kapcsolati tőkét és befolyásoló szerepét.

\section{A kapcsolati tőke és a vállalat viszonya}

A kapcsolati tőke a gazdasági kapcsolatok koordinálását végzi el a piac mellett, azaz kizárólag a piac nem képes minden mechanizmust koordinálni. Ez az össze- 
függés egyúttal rávilágít a piac és a vállalat egymáshoz való viszonyának problémájára. A kapcsolati tőke egyrészt feltételezi a piac jelenlétét, hiszen a piac szabályozza azt, hogy mások képességeihez hozzáférjünk, a kapcsolati töke pedig összeköti a gazdasági élet szereplöit.

A kapcsolati tőke megszerzése, vállalati szintủ adaptálása a technikai újdonságokhoz hasonlóan szintén a gazdasági növekedés irányába ható folyamatokat indít el.

Feltételezem, hogy a kapcsolati tőkének költsége van, amely a korlátozott racionalitás tényét erősíti. Minden egyes vállalat olyan kapcsolati tőkét hordoz, amely lényegesen különbözik a többi vállalat kapcsolati tőkéjétől, azaz a kapcsolati tőke vállalatspecifikus. A kapcsolati tőke jelentősen meghatározza a vállalatok heterogenitását. Ebböl következik, hogy a vállalatok ugyanazon tevékenység végzésénél is lényegesen eltérő kapcsolatokkal rendelkeznek. Ennek oka, hogy a kapcsolati tőke hallgatólagos és szétszórt a vállalatok között, így a kapcsolati tőke koordinációját a vállalatok különböző módon oldják meg. A vállalat tehát azért tesz belsővé egy tevékenységet, mert azt a kapcsolati tőke tekintetében hatékonyabban tudja megszervezni, mint a piac. Végső soron a vállalat kapcsolati tőkéje szerepet játszik abban, hogy mit tud a vállalat a piaci transzfer költségek csökkentésével a piac közvetítése nélkül hatékonyabban megtenni.

A kapcsolati töke több síkon is determinálja a vállalat által belsővé tett tranzakciók körét, azok hatékonyságát, eredményességét, sőt árát is:

$>$ Időtényező: mind rövid, mind pedig hosszú távon a vállalati múltnak nagy szerepe van a vállalat további lehetőségei terén, azaz a korábbi kapcsolati tőke meghatározza a vállalat jövőbeli lehetőségeit, közvetetten az adott térség fejlődését.

> Transzferálhatóság: korábban megállapítottam, hogy a kapcsolati tőke vállalatspecifikus, így legfeljebb csak magas költségekkel (elsősorban a kommunikációs költségek miatt) adható át más vállalatoknak. A kapcsolati tőke transzferálhatóságának magas költségei miatt hatékony megoldás lehet a horizontális vagy a vertikális integráció, amely hatással lehet a területi folyamatok nivellálódására is. Az integráció alapvetően a kapcsolati tőke nehezen átadható, nehezen közvetíthetö, specifikus, nem szerződhető jellegéből következik.

> Terjedés: a kapcsolati tőke terjedésének fontos eszköze a hatékony információs rendszer.

$>$ Összességében a kapcsolati tőke egyszerre adhat magyarázatot a hatékonyság kérdésére, illetve a környezet gazdasági változásainak kihívásaira. A kapcsolati tőke olyan erőforrás, amely nem lehet piaci tranzakció tárgya, így tartós versenyelönyt biztosíthat a vállalat és környezete számára egyaránt (Makszim 2011). 


\section{A kapcsolati tőke és a vállalat belső szervezete}

A kapcsolati tőke hatása a vállalat belső szervezetére három lényeges területet érint: a koordinációs mechanizmusokat, az ösztönzési rendszert, és a kognitív mechanizmusokat. E három terület vizsgálata részben gazdasági, részben pedig szociológiai szempontokat vet fel.

A bizonytalan, változó környezetben a kapcsolati tőke szerepét, hatásait a szervezet tagjai különbözőképpen értelmezik, ezért a szervezetben lennie kell olyan mechanizmusnak, amely ezeket megoldja. Ezt a feladatot a koordináció látja el. A koordinációs probléma azért is kerül a középpontba, mert nemcsak a kapcsolati töke megszerzése tökéletlen, hanem ezek integrálása és vállalati szintủ leképezése is. A gyorsan változó környezet ugyanis feltételezi a szervezeti koordinációt, még akkor is, ha minden egyén teljes mértékben azonosul a szervezeti célokkal. Az ösztönzési rendszernek olyannak kell lenni, amely ráveszi az ágenseket a kapcsolati tőke megszerzésére és a vállalati szervezetbe való adaptálására. Ez a fajta motiváció egyértelmüen a korlátozott racionalitást hívja életre. A megfelelö ösztönzési rendszer kialakítása életre hívja a vállalatvezető szerepének beépítését a rendszerbe. Végső soron olyan irányítási rendszerre van szükség, amely képes koordinálni és a vállalat müködésébe építeni a kapcsolati tőkét. Ennek fontos eszköze a hatékony információs rendszer, mint közös tudásbázis.

A kognitív mechanizmusok szorosan kötődnek a vezetői kompetenciákhoz, ami véleményem szerint azzal indokolható, hogy a kapcsolati tőke szoros összefüggésbe hozható a vezetői hozzáértéssel, képességekkel. A vállalat méretének növekedésével egyre több kapcsolati tőkét kell integrálni és adaptálni, ami pozitív, erős korrelációt mutat a vezetői kompetenciákkal. A vezetői kompetenciák növekedésével nő a kapcsolati tőke megszerzésének esélye.

A kapcsolati tőke megszerzésében és koordinálásában a vállalkozást irányító személy, mint a vállalati elit tagja tölti be a legfontosabb szerepet.

\section{A kapcsolati tőke sajátosságai}

Kutatásom során megállapítottam, hogy szükösnek kell tekinteni az eleve adott kapcsolati tőkét, azaz az újabb kapcsolati tőke megszerzésére való képességet. Hangsúlyozni kell, hogy a vállalat nem eredendően áll a piac felett, csak bizonyos szituációkban képes olcsóbban megszerezni és adaptálni azt a kapcsolati 
tőkét, amelynek mérhetősége bizonytalan ${ }^{1}$. Ez azt jelenti, hogy a kapcsolati tőke mértékének és szerkezetének időbeli és országok közötti összehasonlítása megbízhatatlan, és az így kapott adatok aggregálhatósága is erősen korlátozott. További problémát jelent, hogy a kapcsolati tőke kultúrafüggő, nem könnyen mobilizálható, létrehozása időigényes, illetve erősen függ mások kapcsolati tőkéjének mennyiségétől.

A kapcsolati tőke az elidegeníthetőség szempontjából is speciális, hiszen nincs egyetlen és kizárólagos tulajdonosa. Emellett központi nyilvántartása a többi tőkéhez hasonlóan nehezebben megvalósítható, de különböző hálózatelemzési technikákkal (pl. az interneten keresztül) ma már egyre több ilyen jellegü törekvés létezik. A kapcsolati tőke formalizált elemeit (amelyek pl. szerződések formájában is megjelennek) komoly vállalkozások vezetői információs rendszerük részeként is nyilván tartják és rendszeresen felülvizsgálják, így ezek az objektív módon megjelenő elemek - amennyiben nem titkosak feltérképezhetők. A nem formalizált, szubjektív elemek ilyen jellegü összegyüjtése azonban csak indirekt módon lehetséges, de a versenytársak várható lépéseinek kiszámítása érdekében - ha korlátozottan is -, de számon szokták tartani vállalkozói körökben.

Tartósság szempontjából a kapcsolati tőke a többi tőkétől eltérően viselkedik, ugyanis értéke a használat során nem amortizálódik, hanem még nőhet is. A kapcsolati tőkének van egy anyagi tőkepótló ereje is. Azt azonban, hogy hogyan kompenzál a vállalatok müködésében (pl. tovább müködnek), egyáltalán kompenzál-e, és hogyan fejti ki hatását a területi folyamatokra, statisztikailag nem mérhető. Jelenlétével és gazdasági folyamatokat befolyásoló erejével azonban mindenképpen számolni kell. A kapcsolati tőke szociológiai szempontú értelmezése tehát semmiképpen sem hagyható figyelmen kívül - így a barátság, a kölcsönös függőség, a korrupció részletes elemzése további vizsgálataink tárgyát képezi a jövőben.

\section{A kapcsolati tőke vizsgálata empirikus kutatás alapján}

A kapcsolati tőke fogalmilag, mint személyes kapcsolatrendszer jelenik meg a kérdőíves felmérés (ld. 3. számú melléklet) 10. kérdésében: Értékelje 1-5-ig terjedő skálán, hogy a munkatársak tekintetében milyen kompetenciák fontosak

\footnotetext{
${ }^{1}$ A kapcsolati tőke mérhetősége matematikai értelemben nem lehetséges, esetleg minőségi kategóriák mentén biztosítható az összehasonlítás lehetősége.
} 
vállalkozása számára (nyelvtudás, személyes kapcsolatrendszer, kommunikációs készség, problémamegoldó készség, szakmai gyakorlat, informatikai ismeretek, külső megjelenés, szakmai képzés során megszerzett tudás)! 5 legyen a legfontosabb!

A témához kapcsolódóan a zárójelben felsorolt kompetenciák közül a hangsúlyt, a személyes kapcsolatrendszerre szeretném helyezni a következőkben. Előzetes feltételezésem szerint a kapcsolati tőke meghatározza a vállalkozások alapvető strukturális jellemzőinek alakulását, végső soron a vállalkozások fejlettségét.

A személyes kapcsolatrendszer fontosságának megoszlása 1-5-ig terjedő skálán

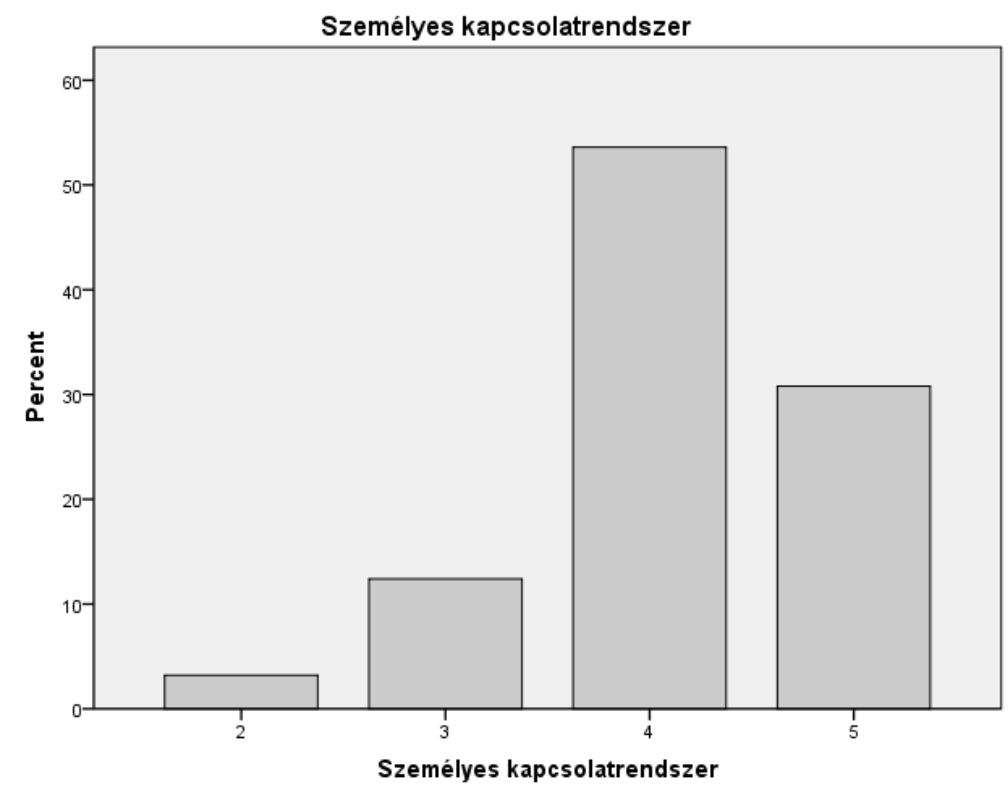

Forrás: Saját kutatás

A 250 megkérdezett vállalkozó többsége (54\%-a) négyesre, 31\%-a ötösre, 12\%a közepesre, míg 3\%-a kettesre értékelte a kapcsolati tőke fontosságát.

Elemzéseim során sztochasztikus kapcsolatok (az esszéhez kapcsolódóan asszociációs- és vegyes kapcsolatok) számítását végeztem el a személyes kapcsolatrendszer és a vállalkozások valamennyi kérdőívben szereplő kvalitatív és kvantitatív ismérvei között. Az egyes valószínüségi kapcsolatok megértése szempontjából - a 10. kérdésen túl - azonban röviden szeretném bemutatni a kérdőíves felmérés további elemeit is, kiemelve legfontosabb kutatási eredményeimet, és a jelen témához kapcsolódó következtetéseimet. 
A kérdőíves felmérés során elsősorban arra kerestem választ, hogy hogyan alakulnak a Szabolcs-Szatmár-Bereg megyei vállalkozások szerkezeti jellemzői (tevékenységi kör, gazdálkodási forma, méret stb.), és milyen szerepet vállalnak a megye vállalkozásai a gazdasági élet dinamizálásában $(\mathrm{K}+\mathrm{F}$, exporttevékenység, foglalkoztatás, oktatással való kapcsolat). Vizsgáltam, hogy van-e kimutatható összefüggés a vállalkozások szerkezeti jellemzői között, illetve az összefüggések milyen hatással lehetnek az adott térség gazdasági helyzetére, fejlettségére.

Mikro-szinten a vállalkozások müködését, tevékenységét, gazdasági szerepvállalási képességét befolyásoló szerkezeti, strukturális jellemzőket vontam be vizsgálataimba, melyeket kvantitatív és kvalitatív csoportba soroltam a következők szerint:

- Kvantitatív befolyásoló tényezők:

- alapítás éve,

- éves nettó árbevétel,

- foglalkoztatottak száma,

- mérlegföösszeg.

- Kvalitatív befolyásoló tényezők:

- tevékenységi kör,

- gazdálkodási forma,

- tulajdoni viszony,

- exporttevékenység,

- kutatás-fejlesztési tevékenység,

- dolgozói kompetenciák,

- a vállalkozás jövőre vonatkozó foglalkoztatási tervei,

- szakmai gyakorlat biztosítása,

- kapcsolati tőke.

A kérdőíves felmérés 1 . kérdése az ágazati szerkezet megoszlására vonatkozott, mely szerint a mintát alkotó Szabolcs-Szatmár-Bereg megyei vállalkozások között jelentős a kereskedelemben $(21,2 \%)$ és a pénzügyi szolgáltatások (20,8\%) területén tevékenykedők aránya, ezt követi (10,8\%-kal) az ipar szektora. A többi ágazat aránya ugyan nem éri el a 10\%-ot, de közülük még mindig meghatározó a szállításban és hírközlésben $(8,8 \%)$, valamint a mezőgazdaságban $(8,8 \%)$ tevékenykedő vállalkozások súlya. 
A mintabeli vállalkozások nemzetgazdasági ág szerinti megoszlása

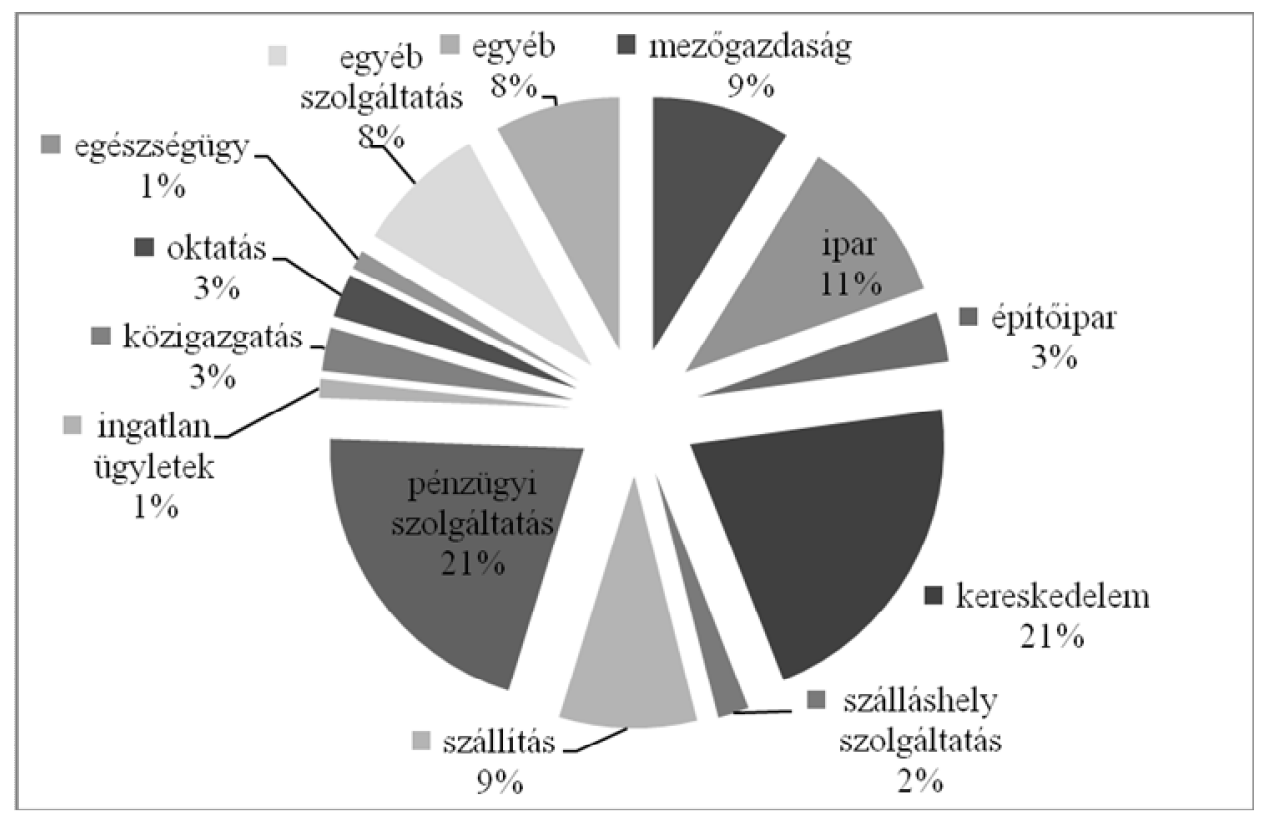

Forrás: Saját kutatás

Szabolcs-Szatmár-Bereg megyében tehát a „hagyományosabb” (tényleges, anyagi átalakító tevékenységet folytató) szektorok töltenek be domináns szerepet, és a megye nehezen tud elszakadni alapvetően agrár jellegétől. Ez azonban nem feltétlenül probléma, hiszen a jövőben éppen a meglévő tradicionális iparágak minőségi kiszolgálására lehetne építeni.

Ezek alapján szignifikáns, közepesen erős a kapcsolat az ágazat és a személyes kapcsolatrendszer között, melyet a szórás hányados mutató: $\mathrm{H}^{2}=0,47$ értékkel jelez. A személyes kapcsolatrendszer egyébként az ingatlanügyletek, valamint a pénzügyi szolgáltatások területén bizonyult a legfontosabb kompetenciának.

A vállalkozások gazdálkodási forma szerinti vizsgálata (2. kérdés) során megállapítottam, hogy a mintabeli vállalkozások többsége, mintegy 62\%-a egyéni vállalkozásként folytatja tevékenységét, $36 \%$ a társas vállalkozások ará-

${ }^{2}$ A vegyes kapcsolat szorosságának PRE-mutatója, amit H-val jelölünk: a variancia-
hányados, ami a külső szórásnégyzet és a teljes szórásnégyzet hányadosából vont négyzetgyök érték. $\mathrm{H}=\sqrt{\frac{S S K}{S S T}}=\sqrt{\frac{\sigma_{\mathrm{K}}^{2}}{\sigma^{2}}}$ (Hunyadi-Mundruczó-Vita, 2001) 
nya és mindössze $2 \%$ az egyéb szervezeteké. A társas vállalkozások $98 \%$-a gazdasági társaság, 2\%-a pedig szövetkezet. A gazdasági társaságokon belül a jogi személyiséggel nem rendelkezők között a betéti társaságok (86\%), míg a jogi személyiséggel bírók között a korlátolt felelősségü társaságok (79\%) dominálnak. Elöbbi (bt.) a mintabeli összes vállalkozás 18\%-át, utóbbi (kft.) pedig a $12 \%$-át teszi ki. A közkereseti társaságok és a részvénytársaságok aránya nem éri el az 5\%-ot.

A vezetöi kompetenciák tekintetében a személyes kapcsolatrendszer a részvénytársaságok körében nagyon jelentős kompetenciának bizonyult, ami arra enged következtetni, hogy a vállalat mérete, tőkeereje szoros összefüggésben áll az adott vállalat kapcsolatrendszerével.

Az alapítás éve (3. kérdés) egyetlen vállalati jellemzővel sem áll statisztikailag kimutatható kapcsolatban a minta esetén.

A 4. kérdés az árbevétel vizsgálatára terjedt ki, melynek eredményei: mintát alkotó vállalkozások túlnyomó többsége, 94,4\%-a, 2 millió eurónál alacsonyabb nettó árbevétellel rendelkezik, 4,8\%-a 2 és 10 millió euró közötti árbevétellel és mindössze $0,4-0,4 \%$-ot képeznek azok a vállalkozások, amelyek $10-50$ vagy 50 millió euró fölötti árbevételt realizáltak 2009-ben. Az alkalmazotti kompetenciák nincsenek statisztikailag kimutatható kapcsolatban a nettó árbevétellel. Ennek oka adódhat egyrészt abból, hogy az árbevétel alakulását sokkal inkább meghatározza az exportteljesítmény és az innováció, másrészt a kapcsolat hiánya magyarázható a kapcsolati tőke hallgatólagos jellegével. Aligha képzelhető el ugyanis olyan vállalkozó, aki vállalkozása üzleti sikerét elsősorban üzleti kapcsolataival magyarázná saját belső képességei helyett.

Az 5. kérdés a Szabolcs-Szatmár-Bereg megyei vállalkozások foglalkoztatotti létszámára, 6. pedig mérlegföösszegére vonatkozott. A vállalkozások többsége (85,6\%-a) 50 fônél kevesebb foglalkoztatottal rendelkező mikro- és kisvállalkozás, 4,8\%-uk 50-249 fös középvállalkozás és 9,6\%-uk 250 fö fölött foglalkoztató nagyvállalat. A személyes kapcsolatrendszer ugyan nincs szignifikáns kapcsolatban a létszámmal, az azonban a minta alapján megállapítható, hogy a kapcsolati tőke a nagyvállalatok esetén sokkal fontosabb vezetői/vállalati kompetencia, mint a kisvállalkozások tekintetében.

A mintában a vállalkozások 88\%-a 2 millió eurónál kevesebb, 12\%-a pedig ennél nagyobb mérlegföösszeggel rendelkezik. Az átlagos mérlegföösszeg 2,3 millió euró, amit jóval meghalad a szórás, 5,7 millió euróval. A személyes kapcsolat rendszer nem hozható statisztikailag összefüggésbe a mérlegföösszeggel.

A tulajdonosi szerkezet elemzése (7. kérdés) alapján megállapítható, hogy a minta vállalkozásainak többsége, mintegy $75 \%$-a 100\%-ban magyar tulajdonban van, kisebb arányt (12\%-ot) képviselnek a 100\%-ban külföldi tulajdonban lévők, továbbá $7 \%$-ot az $50 \%$ feletti magyar és $6 \%$-ot az $50 \%$ feletti külföldi tulajdonú 
vállalkozások. A tulajdoni struktúra és a kapcsolati tőke között nem mutatható ki szignifikáns összefüggés.

Ezzel szemben a személyes kapcsolatrendszer szoros összefüggésbe hozható az adott vállalkozás exportteljesítményével (8. kérdés alapján): e kompetencia nagyobb súlya az exporttevékenységet folytató vállalkozások esetén kiemelkedő, míg az exportot nem végzők körében jelentőségük lényegesen kisebb, ami a kapcsolati tőke piacbefolyásoló erejét tükrözi.

A kérdőíves felmérés 9. kérdése a kutatás-fejlesztés vizsgálatára terjedt ki. A mintabeli vállalkozások mindössze $17 \%$-a végez kutató-fejlesztő tevékenységet, ezen belül is a termékfejlesztés meghatározó. A vállalkozások $83 \%$-a egyáltalán nem végez $\mathrm{K}+\mathrm{F}$ tevékenységet. Ez is azt az országos statisztikát támasztja alá, hogy $\mathrm{K}+\mathrm{F}$ területen még mindig igen elmaradott az ország, de különösen északkeleti térsége (azaz Szabolcs-Szatmár-Bereg megye). Magyarországon jelenleg a kutatás-fejlesztésre fordított GDP hányad 1,2\% körül van, ami messze elmarad az Európai Unió átlagától, a lisszaboni stratégiában meghatározott 3\%-os célkitüzésről nem is beszélve (Török 2005). A mintabeli összefüggések tekintetében az alkalmazotti kompetenciák közül kizárólag a nyelvtudás áll szignifikáns kapcsolatban a kutatás-fejlesztéssel (Cramer's $\left.{ }^{3} \quad \mathrm{~V}=0,33\right)$. Ugyanakkor az előző kérdésben megállapítottam, hogy a nyelvtudás és a személyes kapcsolatrendszer között kimutatható kapcsolat van, így arra következtethetünk, hogy a kapcsolati tőke közgazdaságilag csupán közvetetten áll összefüggésben a kutatásfejlesztéssel, de ez az összefüggés logikailag igazolható (jóllehet statisztikailag nem szignifikáns).

A kompetenciák egymás közötti kapcsolatait megvizsgálva (10. kérdés) arra a következtetésre jutottam, hogy a személyes kapcsolatrendszer leginkább a nyelvtudással hozható összefüggésbe, ami azt bizonyítja, hogy a kapcsolati tökének fontos elemét jelentik a külgazdasági kapcsolatok, valamint a külföldi piacokon való megjelenés és terjeszkedés.

A 11. kérdés a vállalkozások jövőbeli foglalkoztatási terveire irányult, melynek eredményei: a mintabeli vállalkozások döntő többsége $(90 \%$-a) szinten kívánja tartani a foglalkoztatást, 6\%-uk a jövőben bővíteni kívánja a foglalkoztatottak számát. Szintén kedvező jelenség, hogy elbocsátást a vállalkozások mindössze 4\%-a tervez.

Végül az utolsó (12.) kérdés a vállalkozások és az oktatás kapcsolatrendszerét vizsgálta. A minta vállalkozásainak több mint kétharmada biztosít szakmai

${ }^{3}$ A Cramer-féle asszociációs együttható az asszociációs kapcsolat szorosságának méröszáma. $C^{2}=\frac{\chi^{2}}{N \min \{(r-1)(c-1)\}}$, illetve $C=\sqrt{C^{2}}$ (Hunyadi-Mundruczó-Vita, 2001). 
gyakorlóhelyet, vagy szakképzésben, vagy felsőoktatásban részt vevők számára, mintegy 34\%-uk azonban egyáltalán nem foglalkozik gyakorlati képzéssel. Mindemellett a vállalkozások 31\%-a szakképzésben részt vevőknek, 35\%-a felsőoktatásban részt vevőknek biztosít szakmai gyakorlóhelyet, viszont meglehetősen korlátozott számban (leginkább 2-3 fỏ részére).

A személyes kapcsolatok nem állnak összefüggésben sem a jövőre vonatkozó foglalkoztatással, sem pedig a szakmai gyakorlattal.

\section{Összegzés}

Az elméleti áttekintés alapján megállapítható, hogy a téma kereteit biztosító három kulcsfogalom - elit, vállalkozó, kapcsolati tőke - között számos ponton összefüggés tárható fel. Az elit fogalmán belül ugyanis megkülönböztethető a gazdasági elit, melynek szükebb értelmezése azonosítható a vállalati elittel, mint a vállalatot irányító személyekkel. Számos elmélet foglalkozik továbbá a vállalat és vállalati elit, valamint a kapcsolati tőke viszonyával.

Az általam megfogalmazott álláspont szerint a kapcsolati tőke elméleti síkon formalizált és nem formalizált, ún. szubjektív elemekre bontható. A formalizált elemek egy adott vállalkozás szerződéses kapcsolatai alapján vizsgálhatók, míg a szubjektív elemek csak indirekt úton, a vállalati vezetők révén elemezhetők.

A szubjektív elemek saját empirikus kutatásom alapján történő vizsgálata kapcsán megállapítható, hogy a kapcsolati tőke a legfontosabb vállalati jellemzőkkel szignifikáns kapcsolatba hozható, így nemcsak a vállalkozások belső folyamataira van lényeges hatással, hanem közvetetten egy nemzetgazdaság egészében fontos gazdasági tényező. Előfeltevésem tehát igazolást nyert, hiszen a kapcsolati tőkére vonatkozó összefüggések iránya és mértéke a megfelelő statisztikai próba segítségével igazolható.

\section{Felhasznált irodalom}

1. BECKER S. G. (1996): Accounting for Tastes. Cambridge, Harvard University Press

2. BENDIX R. - HOWTON F. W. (1967): Social Mobility and the American Business Elite. In: Social Mobility in Industrial Society. Berkeley: University of California Press 
3. BOSMA N. - PRAAG M. - THURIK R. - WIT G. (2002): The Value of Human and Social Capital Investment for the Business Performance of Start-ups. Tinberger Institute, Discussion Papers, March: 027/3.

4. BOURDIEU P. (1998): Practical Reason: On the Theory of Action. Stanford University Press

5. BURNHAM J. (1965): A ,managerek” forradalma, vagy mi történik most a világban. In: Balogh J. (szerk.): Modern polgári szociológia. 2. kötet, Budapest, 7-83.

6. BYGREVE W. ED (1997): The Portable MBA in entrepreneurship. John Wiley \& Sons, Inc New York

7. FAFCHAMPS M. - MINTEN B. (2002): Returns to Social Network Capital among Traders. Oxford, Economic Papers, 54, 173-206.

8. FALUS IVÁN - OLLÉ JÁNOS (2008): Az empirikus kutatások gyakorlata. Nemzeti Tankönyvkiadó, Budapest

9. FÜLÖP GYULA (2004): Kisvállalati gazdálkodás. Aula Kiadó, Budapest, 15-17.

10. GALASI PÉTER (1994): A munkaerőpiac gazdaságtana. Aula Kiadó, Budapest

11. HERBERT R. F. - LINK A. N. (1982): The Entrepreneur-Mainstream Views and Radical Critiques. Praeger Publisher, New York

12. HISRICH R. D. - PETERS M. P. (1991): Vállalkozás. Új vállalkozások indítása, fejlesztése és működtetése. Akadémiai Kiadó, Budapest. 6.; 12.

13. HOFFERTH S. J. - BOISJOLY J. - DUNCAN G. (1999): The Development of Social Capital. Rationality and Society, 11(1): 79-110.

14. HUNYADI LÁSZLÓ - MUNDRUCZÓ GYÖRGY - VITA LÁSZLÓ (2001): Statisztika. Aula Kiadó, Budapest, 111.; 115.; 124.; 169.

15. KÁLLAY LÁSZLÓ - IMREH SZABOLCS (2004): A kis- és középvállalkozás-fejlesztés gazdaságtana. Aula Kiadó, Budapest

16. KILBY P. (1971): A Macrosociological Interpretation of Entrepreneurship. The Free Press.

17. LASWELL H. D. (1934): World Politics and Personal Insecurity. Chicago

18. LIN N. (2001): Social Capital. Cambridge: Cambridge University Press

19. MAKSZIM GYÖRGYNÉ (2010): Statisztikai helyzetkép SzabolcsSzatmár-Bereg megye vállalkozási szerkezetéről Gazdasági és Társadalomtudományi Közlemények, Nyíregyházi Főiskola, Gazdasági és Társadalomtudományi Kar, Krúdy Könyvkiadó, Nyíregyháza, II. évfolyam 2. szám, 6577. (ISBN 978-963-9909-78-6)

20. MAKSZIM GYÖRGYNÉ (2011): A new Element - the Role of Networking Capital in Explaining the three main Questions of Corporate Theory Journal of Economic and Social Studies, Special edition in English, 
The College of Nyíregyháza, Faculty of Economics and Social Studies, Hungary, Nyíregyháza, 61-69. (ISBN 978-615-5097-25-6)

21. PARETO W. (1972): A kormányzó elit. In.: Huszár Tibor - Somlai Péter (szerk.) A polgári szociológia története 1917-ig/4. Budapest: Tankönyvkiadó, 278-283.

22. RÓNA-TAS ÁKOS - BÖRÖCZ JÓZSEF (1997): Folyamatosság és változás az államszocializmus utáni bolgár, lengyel, cseh és magyar üzleti elitben. Szociológiai Szemle, 2.

23. SCHUMPETER J. A. (1980): A gazdasági fejlődés elmélete. Közgazdasági és Jogi Könyvkiadó, Budapest

24. TÖRÖK ÁDÁM (2005): A Lisszaboni program értékelése és kibontakozásának esélyei. Társadalom és Gazdaság, 27. évf. 1-2. sz., 13-25.

25. VECSENYEI JÁNOS (2002): Vállalkozás. Az ötlettől az újrakezdésig. Aula Kiadó 14.;17.

Makszim Györgyné: okleveles közgazdász

Nyíregyházi Főiskola, Gazdálkodástudományi Intézet, 4400 Nyíregyháza, Sóstói út 31/b 


\section{UNIVERSITY \\ of DEBRECEN \\ FACULTY OF \\ HEALTH}

NYÍREGYHÁZA

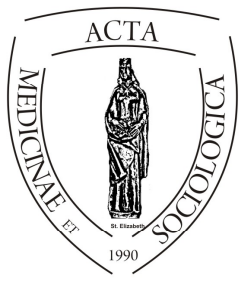

ACTA

MedSoc

VOLUME 5.

2014

\title{
Az idők szava \\ Az angol továbbképzési és szakképzési \\ rendszer kihívásai a XXI. század elején
}

\author{
Zolnai Erika
}

\author{
Debreceni Egyetem, Egészségügyi Kar
}

\begin{abstract}
The Time Password Challenges of the English Further Education and Vocational Education Training System at the Beginning of the 21st Century.

The restructuring of the labour market, the altered needs of the industrial and service sector, and the technological development expect fundamentally different training supplies from the educational system. Substantive, methodological and structural changes are also necessary to increase both the quantitative and qualitative requirements. The expansion of higher education in the 21 st century has destructed the demand from vocational education, while the employers' side is constantly lack of advanced, highskilled employees. On the other hand however, the large number of low-skilled, unqualified underdogs on labour market also accurs as an extremely severe problem. How can a country with a strong economic background as the United Kingdom deal with its vocational education in a situation, where educational traditions, that are resistant to changes - similarly to the Hungarian educational system, have led to unhealthy educational selection? The reforms of the 1980s are helped to restore the economical system, but at the same time serious social and territorial inequalities were left behind.

In this summary, we slightly emphasize the historical aspects of education, but we try to outline the srtucture of vocational education and its relationships with public and higher education, which provides an interpretative frame for this current issues and reform processes. What is actually happening in the last few years? The compulsory education attendance is increased above 18 years, the infrastructure of secondary education has been developed, the vocational educational system is reviewed, the
\end{abstract}


professional training of people under 25 is highly supported, and last but not least tere are several new experiments in the field of financial and collaborational systems. Heroic efforts are put in action in order to renew the apprenticeship system, which tries to raise qualification, work experience and employment, too. The most common obstacle for career starters is lack of work experiance. How it all works, what are its impeding factors and the challanges we have to face?

The vivid discussions within the educational policy, the contradictions between ensuring qualitiy and equity, as well as the activity of professional audience could be highly instructive for us. If one can learn from the experiences of others, same major mistakes, errors or any waste of existing values are probably avoided.

Key words: Education System UK, Vocational Education; Further Education, Apprenticeship, Educational Reform

Absztrakt. A munkaerő-piac átrendeződése, az ipari ágazat és a szolgáltatási szektor megváltozott szükségletei, valamint a technikai fejlődés alapvetően más képzési kínálatot vár az oktatási rendszertől, mint ami az utóbbi évtizedekre jellemző volt. Tartalmi, módszertani és strukturális változások egyaránt szükségesek a megnövekedett mennyiségi és minőségi elvárásoknak való megfeleléshez. Az ezredforduló felsőoktatási expanziója számos fejlett országban elvonta a keresletet a szakképzéstől, miközben a munkáltatói oldal folyamatosan hiányolja a korszerü, magas képzettségü munkavállalókat. A munkavállalói oldalon ugyanakkor feszítő problémaként jelentkezik a nagy számú, munkaerőpiacon esélytelen, alacsonyan kvalifikált, képzetlen fiatal. Mit kezd a szakképzésével ebben a helyzetben egy olyan erős gazdasági háttérrel rendelkező ország, mint az Egyesült Királyság, ahol a változásokkal szemben ellenálló oktatási hagyományok, hazánkhoz hasonló egészségtelen iskolai szelekciót eredményeztek? A 80-as évek reformjai a gazdaságot ugyan rendbe tették, de súlyos társadalmi és területi egyenlőtlenségeket hagytak maguk után.

Összefoglalónkban az oktatástörténeti vonatkozásokra kevéssé tudunk kitérni, de igyekszünk felvázolni a szakképzés struktúráját, a közoktatáshoz és a felsőoktatáshoz való viszonyát, ami egyfajta értelmezési keretét adja a jelenlegi problémáknak, és a reformfolyamatoknak. Mi is történik az utóbbi években? A tankötelezettséget 18+ éves korra emelik, javítják a középfokú képzések infrastruktúráját, felülvizsgálják a szakképzési rendszert, támogatják a 25 év alattiak szakmai képzését, új finanszírozási és együttműködési rendszerekkel kísérleteznek. Heroikus erőfeszítéseket tesznek a gyakornoki rendszer megújítására, ami a képzettség mellett igyekszik a munkatapasztalat-szerzést és a foglalkoztatottságot is növelni. A pályakezdők elhelyezkedésének gyakori akadálya, hogy nincs munkatapasztalata. Hogyan müködik mindez, mik a gátló tényezők, milyen kihívásokkal kell szembenézni?

Az élénk szakmapolitikai vita, a minőség és az esélyegyenlőség biztosításának ellentmondásai a szakmai közvélemény aktivitása igen tanulságos lehet számunkra. Mások tapasztalatából tanulva, talán elkerülhető ugyanazoknak a tévedéseknek, hibáknak az elkövetése, esetleg meglévő értékeink elherdálása.

Kulcs szavak: oktatási rendszer, szakképzés, továbbképzés, gyakornoki rendszer, oktatási reform 


\section{Bevezetés}

Az oktatási rendszeren belül a szakképzés helyzete kitüntetett jelentőséggel bír a társadalmi környezethez való alkalmazkodás, nem utolsó sorban a fejlesztés vonatkozásában. Indikátorként jelzi a közoktatásban gyökerező tendenciákat, problémákat. A munkaerőpiachoz való kapcsolódása miatt a gazdasági folyamatokkal is érzékeny kölcsönkapcsolat jellemzi. A szakképzés tehát magán hordozza az egész rendszer bajait, miközben saját teljesítményproblémái miatt a munkaerő és a nemzetgazdaság versenyképességének egyik közvetlen felelősévé is válik.

Az oktatás egészében fejlesztések és a mérési rendszerek összehangolásának igénye felértékeli a nemzetközi együttmüködés fontosságát, a tapasztalatok megosztását. A nemzeti oktatási rendszerek tanulmányozása felhívhatja a figyelmet a jelenségek, problémák mögött rejlő szerkezeti és funkcionális összefüggésekre. A nem eléggé körültekintő tervezés olyan pozitív visszacsatolásokat indíthat el, melyek váratlan, expanzív módon felerősíthetnek negatív tendenciákat (pl. szelekciós mechanizmusokat). A szakképzés szorosan beágyazódik a közoktatás és a felsőoktatás rendszerébe, vagyis a változtatásokat összehangoltan mindhárom szintet figyelembe véve kell megtervezni.

Coffey és Rhodes 2002-es összehasonlító elemzésében (Coffey \& Rhodes 2002) saját és a CEDEFOP jelentések vizsgálati eredményei alapján három központi kérdés köré rendezi a szakképzés helyzetének értelmezési keretét. (1) Milyen kulcskérdések mozgatják a változásokat a szakképzési rendszerben? (2) Milyen válaszokat ad a VET (Vocational Education Training) struktúrája ezekre a változásokra? (3) Mit jelentenek ezek a válaszok a VET finanszírozásában?

Tanulmányukban a meghatározó európai modelleket ismertetik, megvizsgálják, hogyan reagál a szakképzési rendszer a munkaszervezés változásaira, illetve a foglalkoztatott személyek speciális körülményeire. Felvetik a kérdést, hogy a munkáltatók és az egyének szükségleteinek változásai hogyan jelennek meg a jelenlegi modellekben, a munkának, illetve a munkavállalók szakmai képzettségének, kompetenciáinak milyen új definícióira tesznek javaslatokat. Fontos vizsgálati szempont a finanszírozás, milyen az együttmüködés az állami képző intézmények, az üzleti alapú vállalkozások, az államilag finanszírozott szereplök, és a vállalkozások, cégcsoportok között. Különösen fontos, hogy milyen egyeztetések zajlanak a finanszírozásról a szakképzés hasznát élvező munkáltatók, személyek és az állam között (Lauterbach U. and Sellin B. 2000). A 2003tól kétévente megjelenő NESS Jelentés (National Employer Skills Survey for England Report) hasonló rendszerben vizsgálja a szakképzés különböző indikátorainak alakulását az Egyesült Királyság terültén. A jelentést az UKCESS elne- 
vezésủ bizottság (UK Commission for Employment and Skills rövidítve UKCESS) készíti el és hozza nyilvánosságra ${ }^{1}$. Adataik fontos kiinduló pontjai a helyzetelemzésnek és stratégiai tervezésnek.

\section{A közoktatási háttér}

Az angol közoktatás rendszere rendkívül színes, és több szempontból is tagolt. Számtalan csoportosítás született nemcsak a nemzetközi összehasonlítási igény, hanem a résztvevők eligazodása érdekében is. Elnevezésük tükrözi a hagyományokat (pl. Sixth-form School / nincs magyar megfelelője, Grammar School / Gimnázium) miközben utal az intézménytípus egy-egy jellegzetességére (fenntartó, oktatási forma, alapítás), miközben a hivatalosan használt elnevezések mellett számos nem hivatalos köznyelvi forma is megjelenik. Találkozunk ugyanakkor a nemzetközi nomenklatúrának megfelelő kategóriákkal is (pl. primary; lower secondary, upper secondary education / általános, alsó középiskolai, felső középiskolai képzés), ezek azonban nem iskolatípust, inkább oktatási szintet jelentenek, többféle iskolatípus tartozik hozzájuk.

A részletes ismertetéstől el kell tekintünk, a rendszer megértéséhez a melléklet első két táblázata nyújt támpontot. A tagoltság egyben különbségeket, egyfajta hierarchiát is jelent a különböző programot nyújtó iskolák között. A szülők szabad iskolaválasztási joga és az iskolák felvételi rendszere (bár részben korlátozott) a világ egyik legalacsonyabb életkorban induló iskolai szelekcióját eredményezi. A legjobb képességü gyerekek sorsáról már 11 évesen eldöntik, hogy az akadémiai képzés, vagy a szakmai képzések irányába induljanak-e tovább. Ez az egyik legrégebbi, és legnehezebben kezelhető dilemmája az angol oktatáspolitikának. A reformoknak egyszerre kellene az oktatás hagyományokra épülö elitképzés minőségi elvárásait megtartani, ami a társadalmi különbségeket kiélezi, miközben az esélyegyenlőség, társadalmi integráció feladataira is megfelelő válaszokat kellene adnia. Érthető módon a jobb és bal oldali kormányok eltérő módon súlyozták a problémát, és a nagy társadalmi nyomás miatt eddig egyik oktatási reformnak sem sikerült érdemlegesen befolyásolni ezt a helyzetet.

A finanszírozás és szabályozás tekintetében az Egyesült Királyságban a központi kormányzat teljes felelősséget vállal az oktatási rendszerért, ugyanakkor az oktatás irányításának rendszere decentralizált, a fenntartói feladatokat az önkormányzatok, az önkéntes szolgáltatók, az egyházak, az oktatási intézmények irá-

\footnotetext{
${ }^{1}$ UK Employer Skills Survey 2011: First Findings. http://www.ukces.org.uk/assets/ukces/docs/publications/uk-ess-first-findings-2011amended-22-dec.pdf
} 
nyító testületei, és a tanári szakma együttesen végzik. Az angol iskolások mintegy 93 százaléka állami finanszírozású, bár különböző fenntartói kezelésében lévő iskolában tanul (önkormányzat, egyház, civilszervezet). Ezekben az oktatás ingyenes, csupán az állami bentlakásos iskolák számítanak fel meghatározott térítési díjat. A fennmaradó 7 százalék választja a magas tandíjjal müködő, bentlakásos magániskolákat.

A felügyeletet és a fenntartói feladatokat tehát a helyi önkormányzatok testületei végzik, az állam részéről ${ }^{2}$ az Ofsted (Office for Standards in Education Oktatási Hivatal) ellenőrzi a feltételeket és a minőséget. Az állami iskolák nagyfokú önállósággal rendelkeznek, önállóan gazdálkodnak, felelősek a saját költségvetésükért és a személyzettel kapcsolatos döntésekért. Saját irányító testületeik látják el az általános irányítási feladatokat, ezekben minden érdekelt fél képviselteti magát benne (iskola vezetése, tanárok, szülők), a stratégiai vezetést megosztja az iskolaigazgatóval, és utóbbi hozza a napi döntéseket. A széles körü autonómia és decentralizáció ellensúlyozásaként az angol oktatási rendszert nagyfokú elszámoltathatóság jellemzi, beleértve az iskolai teljesítmények adatainak nyilvánosságát, és az iskola rangsorokat is.

A hatályos oktatási törvény a tankötelezettséget több lépésben 2015-ig 18+ $\mathrm{ra}^{3}$ emeli, ami a közép és felsőfokú képzések, ezen belül a szakképzés jelentőségét és szerepét növeli. Minden iskolára érvényes a Nemzeti Alaptanterv (National Curriculum), melyet az „Oktatási és szakképzési törvény” (2008 Education and Skills Act) ${ }^{4}$ szabályoz, és ez adja a keret a helyi tanterveknek. A három központi tantárgyat (angol, matematika, és természettudomány) 5-16 éves korig kötelező tanulni, míg az alaptárgyaknak nevezett tantárgyakat egy vagy több évfolyamon (Kay Stage / KS) tanulják (müvészetek és dizájn, állampolgári ismeretek, dizájn és technológia, földrajz, történelem, IKT, modern idegen nyelvek, zene, testnevelés). Ezen kívül minden évfolyamon van vallási nevelés, és a KS2től szexuális nevelés, karriernevelés, végül munkával kapcsolatos oktatás a 3. és 4. KS-től (hetedik osztálytól). A tantervnek fontos része a munkatapasztalatszerzés, ami szoros kapcsolatot épít ki a helyi cégekkel, vállalkozókkal, mivel ők biztosítják a gyakorlati helyeket. A készségek, képességek megismerése és fejlesztése mellett ez jó lehetőség a tanulók számára a továbbtanulással kapcsolatos döntésekhez szükséges pályaorientációs információk megszerzésére.

Az angol oktatási rendszerben többféle iskolatípus és hagyományos tagozódás él egymás mellett a fenntartás és finanszírozás különbségein túlmenően is. A ha-

\footnotetext{
${ }^{2}$ Oktatási Minisztérium (Department for Education - Dfe), és az Üzleti, Fejlesztési és Szakmai Minisztérium (Department for Business, Innovation and Skills - BIS) felügyeli.

${ }^{3} \mathrm{Nem}$ az életkor betöltéséhez kötött, hanem a megkezdett iskolai év befejezéséhez, ami többnyire 19 éves kor.

${ }^{4} \mathrm{http}$ ://www.educationengland.org.uk/documents/pdfs/2008-education-and-skills-act.pdf
} 
gyományok egymás mellett élése a rendkívül tagolt vizsgarendszerben is tükröződik. Számos vizsgarendszer létezik a központi állami vizsgák mellett. Ezek részletes ismertetésétől ugyan el kell tekintenünk, azonban utalnunk kell rá, hogy a szakképzés hagyományai és jellegzetességei között a minősítési rendszernek és az ehhez kapcsolódó vizsgarendszernek meghatározó szerepe van, éppen ezért a szakképzés kapcsán később visszatérünk rá.

A tanárokat a nemzeti szinten elfogadott életpályamodell (School Teachers' Pay and Conditions Document) szerint foglalkoztatják, anyagi megbecsültségük az európai élmezőnyéhez tartozik. Kezdő fizetésük magasabb az átlagos diplomás kezdő fizetésnél (21.804-27.270 GBP), a vezető tanárok ennek kétszeresét is megkereshetik (57.520-64.677 GBP). Az iskolaigazgatók juttatása ennél lényegesen magasabb - intézménytől függően 43 ezertől akár 113 ezer fontig terjed. A fizetések erősen függnek a tanárok személyes teljesítménytől, az éves értékelések progresszív előrejutást biztosítanak a fizetési kategóriákban ${ }^{5}$. Látni fogjuk, hogy az utóbbi évtizedekben és jelenleg is az Egyesült Királyság azon európai országok egyike, amelyek a legtöbbet költik az oktatási rendszerükre, ami nagyarázza, hogy ennek megfelelő teljesítményt és hatékonyságot várnak el a pedagógusoktól.

\section{A szakképzés betagozódása az iskolarendszerbe, tanulási utak}

A szakképzés törvényi hátterét az 2009-ben megszületett „Szakképzési törvény” (Apprenticeships, Skills, Children and Learning Act 2009) ${ }^{6}$ jelenti. Ahogyan a 2es számú táblázat mutatja a közoktatás és a szakképzés szorosan összekapcsolódik, rendszere csak összefüggésükben értelmezhető?

\footnotetext{
${ }^{5} \mathrm{http}: / /$ www.education.gov.uk/get-into-teaching/salary

${ }^{6} \mathrm{http}: / /$ www.legislation.gov.uk/ukpga/2009/22/notes/contents

${ }^{7} \mathrm{Az}$ áttekinthetőség érdekében számos intézménytípust nem szerepeltetnek a legtöbb rendszerismertetésben. A mellékletben bemutatott táblázatban igyekeztünk összefoglalni a különböző időszakokban kialakult iskolatípusokat. A különböző elnevezések mögött többnyire eltérö fenntartói, tulajdonosi struktúra, esetleg finanszírozás fedezhető fel. A rendszer időbeni fejlődése hatására a tradicionális iskolatípusok és a különböző oktatási törvényekhez kötődő újabb alapítású formák párhuzamosan müködnek.
} 


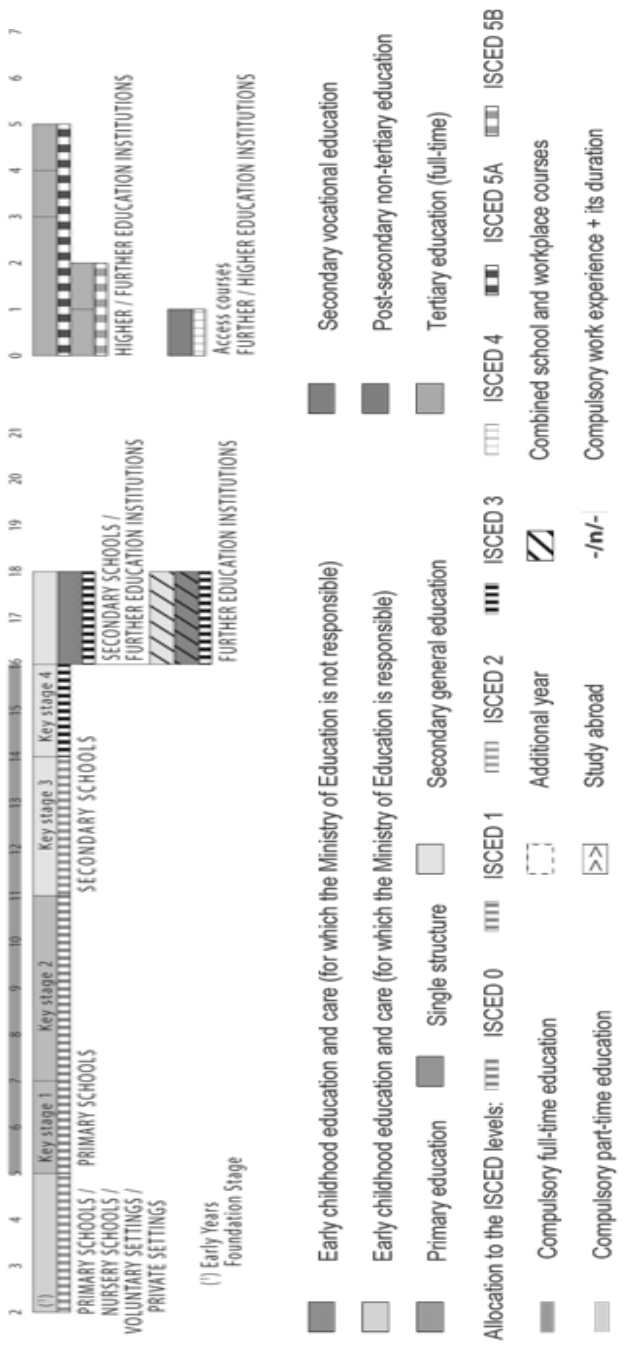

1. táblázat. Az angol oktatás struktúrája és a továbbtanulás.

Forrás: Eurydice https://webgate.ec.europa.eu/fpfis/mwikis/eurydice/index.php/UnitedKingdom-England:Overview 
Az alsó középfok szintjén pályaorientációs céllal munkatapasztalatokhoz jutnak a diákok, s mikor elérik 16 éves kort ${ }^{8}$ és megszerezték a GCSE (general certified secondary education) minősítést, akkor 2 tanulási útvonal lehetséges. Elméleti (academies), vagy szakmai (vocational) végzettséget (képesítést) szerezhetnek, melynek esélyei a különböző középiskola típusokban nem egyformák, ide pedig 11 évesen felvételiztek. Korábban a munkavállalásra is lehetőség volt, bár az alacsony, inkább hiányzó képesítések miatt szinte esélytelenül. Vannak tehát akik elindulhatnak az elméleti továbbképzés (further academic qualification) irányába vagy a szakmai karrierutat választják, így a kétéves szakképzés keretében képesítéseket szereznek különféle iskola formákban az iskolarendszeren belül (Sixth Form, ill. Sixth Form College vagy Further Education Institute).

Az említett szakképző iskolák 18 évesnél idősebb felnőttek számára is hirdetnek tanfolyamokat, ugyanakkor felnőttképzést indítanak az iskolarendszeren kívüli intézmények is. Az oktatásnak ezt az ágát nevezik továbbtanulásnak, vagy szakképzésnek (Futher Education, Vocational Education). Az eredetileg a felsöszintü (tertiary) szakképző intézmények (Polytechnics, Müszaki Főiskola - Angliában eredetileg 30 létezett), az 1992-es „Továbbképzési és felsőoktatási törvényben" önálló egyetemi rangot kaptak".

A Müszaki Főiskolák átvezetnek bennünket a szakképzés felső fokú szintjére és a felsőoktatáshoz való kapcsolódási pontokhoz, melyben megtaláljuk a gyógyító-segitő, továbbá az adminisztráció és a menedzsment területen dolgozó szakemberek képzését is, melyek a felsőoktatáson belül más szabályozás alá tartoznak, mint a szakképzés. Ezek már felsőfokú (Level 4 Qualifications) minősítéseknek megfelelő diplomákat adnak az említett szakmai területeken, hasonlóan a hagyományosnak tekinthető elméleti egyetemi képzésekhez és az ún. szabályozott képzésekhez (oktatás, jog, orvostudomány, pszichológia, üzleti világ). melyek akadémiai végzettségek, diplomák és nem a szakmai végzettségek körébe tartoznak. Az utóbbi évek képzési reform folyamata során meghatározták a különböző képesítési rendszerek megfelelőségét (pl. akadémiai és szakmai), erről később szólunk.

\footnotetext{
${ }^{8}$ Korábban oktatási kötelezettség végét jelentette, napjainkban ennek elindult a fokozatos emelése 18/19 évre.

${ }^{9}$ A felsőoktatási rendszer minősítéseinek összefüggései: http://www.ecctis.co.uk/europass/documents/ds_chart.pdf
} 


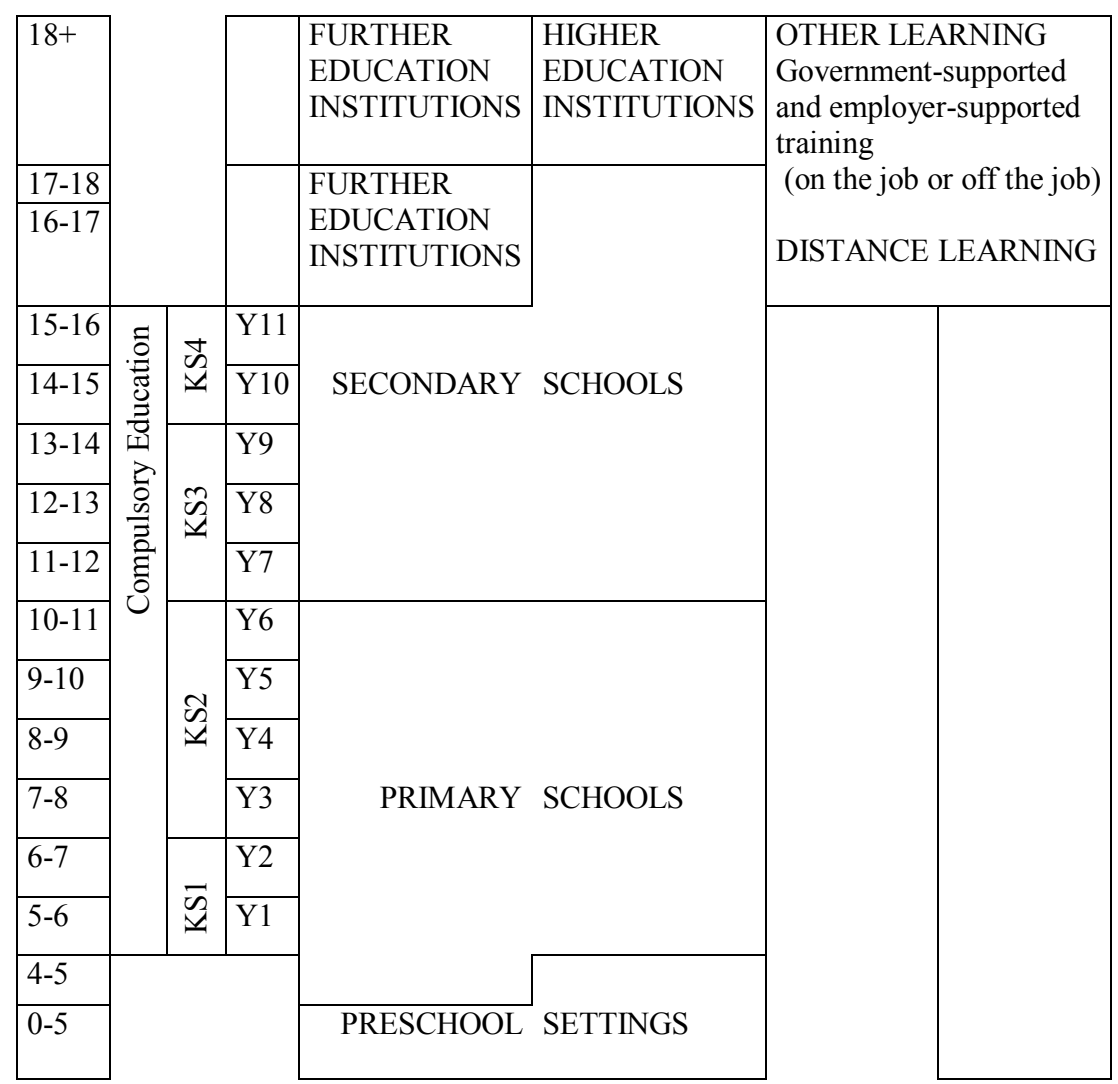

2. táblázat. Szakképzés helye az oktatási rendszerben forrás: $\mathrm{UNESCO}^{10}$

\section{Az angol szakképzési rendszer iskolarendszeren belüli, és iskolarendszeren kívüli elemei}

A továbbképzési kurzusok a „college” szektorban (főiskolai) állnak rendelkezésre, melynek intézményei vagy állami, vagy független fenntartásúak lehetnek, bár az utóbbi csupán az 5\%-át teszi ki az összesnek. Az iskolarendszeren kívüli szervezetek, szakképzési központok sokféle funkcióval rendelkeznek a tanfo-

\footnotetext{
${ }^{10} \mathrm{http} / / /$ www.ibe.unesco.org/Countries/WDE/2006/WESTERN_EUROPE/United_Kingd om/United_Kingdom.htm
} 
lyamok szervezésén túl is, például különböző szolgáltatásokat nyújtanak, melyekkel a programok elérhetőségét kívánják növelni (pl. tanácsadói szolgáltatások, felvételi előkészitő tanfolyamok).

A továbbképzési rendszer 2-es számú táblázat által szemléltetett módon átfedi a középfokú oktatást és a felsőoktatást is. Egyes programok már 11-16, mások 16-19 éves kor között nyújtanak lehetőségek szakképzettség megszerzésére, utóbbi életkorban a felsőoktatáshoz kapcsolódva is léteznek programok. Az FE continuuing education néven is ismert, régebbi irodalmak post compusory-ként is használták, amíg a kötelező oktatás 16 éves korig tartott. Ennek keretében beszélhetünk teljes vagy részidős képzésekről (full-time or part-time education) is, utóbbiak gyakran munka melletti képzések, akár fiatalok, akár felnőttek számára. Maguk a képzőintézmények lehetnek iskolarendszeren belüli és azon kívüli úgy nevezett képzési szolgáltató intézmények.

1994-től vezették be az államilag finanszírozott ún. Modern Gyakornoki Rendszert (Modern Apprenticeship) a szakképzettség növelése céljából, melynek lényege „quality training on a work-based (educational) route", azaz munkalapú képzési filozófia. Az alacsonyabb képzési szinteken a cél a munkatapasztalat biztosítása, minél több munkahely, szakma megismertetése, majd a különböző fokú szakmai kompetenciák elsajátítása. Az eltérő felkészültségü diákok előképzettségükhöz igazodva elégítik ki, segítenek pótolni a hiányosságaikat, és kínálnak angol nyelvtanfolyamokat is. A program fö finanszírozója a Business And Technology Education Council (Üzleti és Müszaki Oktatásfinanszírozási Tanács). John Hayes Gyakornoki rendszerért felelős Miniszter (Joint Minister for Apprenticeship) felügyelete mellett a Nemzeti Gyakornoki Szolgálat (National Apprenticeship Service) hozta létre a Gyakornoki Program Tanácsot (Apprenticeship Program Board), ami koordinálja a két felelös minisztérium (Department for Business Innovation \& Skills és a Department for Education) bizottságait (BIS - Skills Strategy Board és DfE- Curriculum and Qualifications Board) és jelentést készít a felelős miniszternek (Minister for Apprenticeship) ${ }^{11}$. A gyakornoki rendszer megújítására számos kísérlet történt az utóbbi évtizedekben, a legfrissebb változásokról részletesebben a reformfolyamatok kapcsán számolunk be. A gyakornoki rendszer (1994-től Modern Gyakornoki Rendszer) tanulói létszámának és összetételének változásait 1950-2010-ig a 4-es számú melléklet grafikonján lehet követni.

\footnotetext{
${ }^{11}$ Business Plan 2012-13 of National Apprenticeship Service. http://www.apprenticeships.org.uk/About-Us/ /media/Documents/NAS-201213BusinessPlanforstakeholders-July2012.
} 
A szakmai képzéseket a finanszírozás forrása szerint 4 kategóriában kezelik:

1. Szakmai alapképzés (kezdő szakképzés / Initial Vocational Training IVT vagy FE continuuing education az amerikai angol terminológia szerint) 16-19 évesek képzése (kivéve a felsőoktatást) föiskolákon (Colleges) 55\%, munkahelyeken $37 \%$ és iskolákban $8 \%$ zajlik. Ez államilag finanszírozott, tandíjmentes képzés.

2. Szakmai továbbképzés (Vocational Education and Training) azokat szólítja meg, akik foglalkoztatásban vannak, tartalmazza a 16-19 éveseket az IVT-ben a munkahelyeken, képzési szolgáltatóknál, föiskolákon. A franchise -nak, vagy főiskolák/ munkahelyi alapú képzést végző trénerek számának növekedése jellemzi, a szakismeretek aktualizálását szolgálja.

3. Felnöttképzés (Adult Education) - az iskolarendszeren belüli intézmények is kínálnak tanfolyamokat felnőtteknek, részidőben, esetleg munkahelyeken, de a speciális felnőtt-képző intézmények programjai is elérhetőek. A támogatott felnőtt képzés legújabb stratégiája szerint a National Institute of Adult Continuing Education (NIACE) ${ }^{12}$ szervezett, irányított formában, nemzeti szinten kívánja megvalósítani a „több, különböző és jobb felnőtt képzést"13.

3. Képzések munkanélküliek számára. Képzések azok számára, akik 19 évesek elmúltak és munkanélküliek. Piacképes szakismeretek az elhelyezkedési esélyek javítása érdekében.

A képzéseket lebonyolító intézmények nagyon változatosak, és inkább szakmai szempontból specializáltak. Különböző szintü minősítő vizsgákra felkészítő képzéseket indítanak, és nem választhatók el a Modern Apprenticeship (Modern Gyakornoki) rendszertől, melynek megújítása jelenleg is zajló, sok vitát kiváltó folyamat. A képzéseknek három szintje van, (1) Intermediate (5GCSE); (2) Advance (2A); (3) Higher (NVQ Level 4 vagy Foundation Degree) ${ }^{14}$.

A Felnőtt (25 év felettiek) Gyakornoki rendszer (Adult App.), ugyanezt a szakmai tapasztalatszerzést és képesítés megszerzését nyújtja. 16-18 éves kor között a képzés költségét a kormány finanszírozza, 18-24 éves kor között az $50 \%$-a terheli a tanulót, a másik felét a kormány átvállalja, 25 éves kor felett a képzésért fizetni kell, melyhez diákhitelt lehet igénybe venni.

A gyakornoki rendszer egyszerre biztosít munkahelyi gyakorlatot, ahol a tanulót meghatározott minimálbér, szabadság illeti meg, és tanfolyamot, ahol a szakmai készségek képességek mellett angolt, matematikát, és természettudományos tantárgyakat is tanulnak. A szakmai szerepnek és munkakörnek megfe-

\footnotetext{
${ }^{12} \mathrm{http}: / /$ www.niace.org.uk/about-us/governance

${ }^{13} \mathrm{http} / / / \mathrm{www}$. niace.org.uk/sites/default/files/documents/policy/niace_strategic_plan_201 3-18.pdf

${ }^{14} \mathrm{http} / / /$ www.legislation.gov.uk/ukpga/2011/21/pdfs/ukpga_20110021_en.pdj
} 
lelő, előre meghatározott kreditek megszerzésére nyílik lehetőség és felkészítenek a minősítő vizsgára.

A képzéseket biztosító intézmények között találjuk a General Further Education és a Tertiary Colleges intézményeit, valamint a Sixth Form College-kat, és Specialist College-okat (ezek mezőgazdasági, kertészeti, dráma, és tánc specializációjú iskolák). Ezek már a felsőfokú szakképzésekhez tartoznak 18 éves kor felett, párhuzamosan az egyetemekkel és egyéb felsőoktatási intézményekkel. A felsőfokú szakképzés tehát külön intézményrendszerben valósul meg.

Az utóbbi időben számos új elemmel bővült az egyébként is színes rendszer, mely tartalmazza a továbbképző (szakképző) főiskolákat (Further Colleges), müszaki föiskolákat (Technical Institute), szakképző központokat (UTC - University Technical Colleges), müvészeti és müszaki föiskolákat (Art and Technical Collages), felsőfokú szakképző intézményeket (Tertier Colleges; alap, közép és felsőfokú képzési tagolásnak megfelelően). A 16 éves kor utáni középfokú oktatásban a Sixth Form College-ok is nyújtanak szakmai képzéseket. Ezek nálunk inkább a középiskolai szintnek felelnek meg, vagy a franciaországi, vagy a Romániában ismert Líceumnak. A skála másik végén azok a föiskolák vannak, melyek alap szintủ szakmai képzéseket nyújtanak, és kapcsolatban vannak a felsőoktatással és az Egyetemi szektorral (HE).

Röviden összegezve, a szakképzés rendszerében a finanszírozás a résztvevők életkori csoportjaihoz kötődik, ennek megfelelően vállal szerepet a kormány, illetve jelenik meg az önfinanszírozás és a diák hitel. A szakképzésben szerepet vállaló intézmények és programok szövevényes rendszerében a képzési célok, kimenetek alapján egyéni karrierutakat ajánlanak a jelentkezőiknek ${ }^{15}$. A legalacsonyabb képzési szinten (Traineeship) is tartozik a munkatapasztalat-szerzéshez angol és matematika oktatás, valamint a munkavállalói készségek fejlesztése. A képzési szintek növekedésével a szakmai kompetenciák egyre önállóbb munkavégzésre adnak felhatalmazást. A szükséges információk internetes alkalmazások segítségével böngészhetőek ${ }^{16}$, a döntésekben pedig tanácsadó szolgáltatások ${ }^{17}$ segítik a tanulókat. A képző intézmények egy része egyetemi felvételi vizsgára is felkészít és a szakmai vizsgák mellett az érettségi vizsgát is megszerzik a diákok. A tanulói utakat a megszerzett, illetve megcélzott vizsgák határozzák meg, a szakmák illetve a foglalkoztatás kritériumai a későbbiekben ismertetésre kerülő minősítési rendszer tartalmazza. Ez a kimeneti kritériumok mellett a képzések indítására és adminisztrációjára vonatkozó szabályozásokat is tartalmazza. Szolgáltatók széles köre

\footnotetext{
${ }^{15} \mathrm{http}: / /$ www.semta.org.uk/careers

${ }^{16} \mathrm{https}$ //apprenticeshipvacancymatchingservice.lsc.gov.uk/navms/forms/candidate/Appr enticeships.aspxó

${ }^{17} \mathrm{http}$ ://www.nacro.org.uk/what-we-do/education-services/
} 
érhető el az üzleti vállalkozásként müködő online adatbázisban ${ }^{18}$, ez azonban csupán egy nyilvántartás, nem hivatalos képzési jegyzék. Az Ofqual rendszerében az intézményt és a programot is akkreditáltatni kell.

\section{Képzési szolgáltatók}

A képzések megvalósításában piaci és non-profit szereplök is részt vesznek, mint képzési szolgáltatók, kínálatuk meglehetősen különböző, attól függően milyen célcsoportra specializálódtak.

Az AELP (Association of Employment and Learning Providers) ${ }^{19}$ a foglalkoztatási és képzési szolgáltatók legnagyobb bázissal rendelkező egyesülete Nagy-Britanniában, több, mint 600 tagja van, és non-profit és önkéntes szektor képző és foglalkoztatási szolgáltatóinak a szervezeteként müködik. A munkaalapú oktatásban érdekelt továbbképző intézmények (FE colleges) 50\%-át tömöríti, erőteljes lobbitevékenységet folytat, tagjai a képzések mintegy $70 \%$-át nyújtják országszerte.

Meg kell még említenünk a LANTRA szervezetét, aminek a bázisa az SSC (Sector Skill Councils), s mint ilyen a szakképzésben az ipari vállaltok képzési igényeit képviselik, a képzések és szakképzés, valamint munkaerő fejlesztését tekinti az üzleti sikerek alapjának.

A képzési programok ezeknél a szolgáltatóknál is lehetnek teljes, vagy részidősek, különböző célú tanfolyamokat ölelnek fel, melyek eltérő arányban tartalmazzák az alkalmazkodási készséget növelő (Skill for life), és speciális szakmai készségeket (professional skills). Kínálnak tanfolyamokat az élethosszig tartó tanulás keretében közösségfejlesztő céllal is (Community Learning), és a felnőttképzésben szakmai tanulás, továbbképzés céljából, a gyakornoki rendszertől függetlenül.

\section{University Technical Colleges}

Érdemes külön kiemelni a legújabb intézménytípust, mivel ez képviseli a legkorszerübb szemléletet a képzők és munkáltatók kapcsolatában, valamint a finanszírozás megvalósításában. Ezek speciális, újonnan alapított müszaki főiskolák (UTC $^{20}$, melyekből 2013-ig 17 kezdte meg a működését, és 2015-ig legalább 50 indítását tervezik. Leginkább a szektorok szoros együttmüködése különbözteti

\footnotetext{
${ }^{18} \mathrm{http}: / /$ www.trainingdirectoryuk.com

${ }^{19} \mathrm{http}: / /$ www.aelp.org.uk/about/

${ }^{20}$ University Technical College http://www.utcolleges.org/
} 
meg a többi iskolatípustól, hiszen indításának feltétele egy egyetem valamint ipari, üzleti cégek strukturális és funkcionális jelenléte az oktatásban, ami nem csupán adminisztratív, alapítói szerepet jelent, hanem aktív részvételt. Az iskolakötelezettség életkorának felemelésével a képző intézmények számát, formáit, és kapacitását is bővíteni kellett.

A képzési kínálatukra jellemző, hogy általában 1 vagy 2 éves egymásra épülő kurzusokat indítanak (esetenként szakmacsoportos formában), finanszírozásuk, müködésük azonban lényegesen eltér a régebbi típusoktól. 14 éves kortól 19 éves korig kínálnak szakmai képzéseket a diákoknak (egyes iskolák 11 éves kortól indulnak, de Sixth Form rendszerben is müködnek, azaz középiskola után is elkezdhetőek).

Lord Baker, korábbi Oktatási Államtitkár kezdeményezésével és támogatásával indult a fejlesztés, bár számuk még nem jelentős, figyelemre méltó a szektorok együttmüködésére és a szakképzés rangjának az emelésére tett kormányzati eröfeszítés. Különböző szakmákban kínálnak különböző szintü képzéseket (Apprenticeships Leves 2 - L4), egyetemi felvételi előkészítést és felvételi vizsgát, érettségit, továbbá felzárkóztatást is végeznek. Bentlakásos formában müködnek, meghatározott költségtérítést kell fizetni, szigorú napirend és egyenruha viselés kapcsolja a tradicionális angol oktatási rendszerhez. A szakmai kínálat a helyi lehetőségekhez és egyben igényekhez igazodik, azaz kapcsolódik a munkaerőpiachoz, meglévő foglalkoztatáshoz, hiszen a gyakorlati képzés ezek bevonásával történik.

A programmal kapcsolatban számos kritika is elhangzik a szakmai szövetségek oldaláról, mivel véleményük szerint így tovább darabolódik a képzési rendszer, és a meglévő intézményektől jelentős forrásokat vonnak el. Többségükbe 14 éves kortól jelentkezhetnek, amit sokan túl korainak tartanak a specializált szakmai elköteleződéshez.

\section{A képzés a minősítési rendszerek és vizsgaköz- pontok összefüggései}

Az angol képzési rendszerben a szakmák gyakorlásához szükséges képesítési elöírásokat a Nemzeti Képesítési Keretrendszer tartalmazza (National Qualifications Framework QCF $)^{21}$, melyhez a képzési krediteket a Minősítési és Kredit Rendszer (Qualifications and Credit Framework) rendeli hozzá, az Office of Qualifications and Examinations Regulation (Ofqual - Képzési és Vizsgaszabályozási Hivatal)

${ }^{21} \mathrm{http}: / /$ ofqual.gov.uk/qualifications-and-assessments/qualification-frameworks/ 
ellenőrzi és nyilvántartja a megszerzett képesítéseket, valamint a képző intézményeket akkreditálja az intézményeket és a képzéseket. Az angol rendszerben sokféle hagyomány él, számos vizsgarendszerrel és tradicionális vizsgaközponttal az állami mellett, így az országon belüli megfeleltetés is rendkívül fontos volt az Európai Képesítési Keretrendszerrel való összehangolás mellett.

Különböző szinteket lehet választani a kötelező középiskolai képzésben az alap készség tréningektől (basic skill training) a felsőfokú szakképzettségig; mint City and Guilds, Higher National Diploma or Foundation Degree. A GCSE és A szintü programok széles választéknak az a célja, hogy kiegészítse a közoktatásban kimaradt képességeket és ismereteket. Ez a legnépszerübb formája a felsőoktatásba való belépésnek (a legutóbbi vizsgálatok szerint ezek népszerűek ugyan, de nem eredményesek, kevesen kerülnek be ezen az úton a munkaerő piacra vagy a felsőoktatásba).

A felsőoktatási intézmények „Foundation and Access” elnevezésü egy éves elökészítő kurzusokat indítanak, melyek az egyetemi felvételi kritériumoknak megfelelőek (a természet tudomány, mérnöki, humán és orvostudomány területén). Számos különböző intézmény kapcsolódott ezekhez a felkészítő programokhoz, melyek belépők az egyetemi képzésbe.

A GNVQ (General National Vocational Qualification / Általános Nemzeti Szakmai Minősítés) alap, közép és felsőfokú programok alternatívát nyújtanak a diákoknak a tudományos A szintü képesítések mellett, amivel az egyetemre és a munkaerőpiacra is mehetnek. Népszerü területek: Art and Design; üzleti élet, egészségügyi és szociális terület, szabadidő és turizmus, kézmüipar, vendéglátás és ellátás, tudomány, mérnöki munka, informatika.

Jól példázza a végzettségek komplikált rendszerét a különböző végzettségek egyenértéküségének a bemutatása, melyet a „National Vocational Qualifications” és a „General National Vocational Qualifications” licenszei tartalmaznak. A 2016-ra meghirdetett hivatalos képzési lista, melyre 14-16 éves kortól jelentkezhetnek a tanulók 2015-ben, 20 oldalon kínál 60 - 480 kredit értékü (zömében 120 és 300 kredites) képzéseket, különböző képesítési szinteken (awards, certificate, diploma L1 és L2, melyek egyenértéküségéről a 3. ábra nyújt áttekintést). ${ }^{22}$ Ezeket a minősítéseket vizsgaközpontokban lehet megszerezni, melyekre a képző intézmények tanfolyamain lehet felkészülni. nagyon gyakoriak az alacsony képesítésre jogosító tanfolyamok, melyek az NVQ 1 és 2es szintjét nyújtják (6. táblázat).

A vizsgák minősítési kritériumait (Qualification standards) nyilvánosan közzé teszik. A kritériumok az utóbbi évek reformjai során sokat változtak ugyan, de alapvetően kompetencia alapú maradt a rendszer, az elméleti tudás kisebb

\footnotetext{
${ }^{22}$ https://www.gov.uk/government/uploads/system/uploads/attachment_data/file/266128/ 2016_KS4_Publication_list_final.pdf
} 
szerepet játszik. A vizsgán elsősorban azt határozzák meg, hogy a vizsgázónak milyen feladatok végrehajtásának képességével kell rendelkeznie az adott szinten. Feltételezik, hogy a feladatok végrehajtásához elméleti ismeretekkel is rendelkezni kell, de ezt külön nem kérik, és nem is rögzítik, mint a felkészítés feltételét. Ez alapvetően különbözik a magyar, de számos európai oktatási gyakorlattól, és curriculum rendszertöl. A vizsgán szimulált munkahelyi környezetben kell gyakorlati feladatokat végrehajtani. A szabályozást törvényben írják elő, a legújabb a 2011-es ${ }^{23}$. A szabályozás végrehajtásáért felelős intézmény az Office of Qualifications and Examinations Regulation Ofqual ${ }^{24}$, melynek honlapján minden szükséges és aktuális információ, jelentés és adat, megtalálható.

A National Diploma Programme-ok, vagyis a Nemzeti Diploma Programok azoknak a diákoknak nyújtanak lehetőséget, akik elköteleződtek valamilyen részterület iránt, mint például elektronika, informatika. Ezek a képzések olyan képességeket dolgoznak ki, melyek biztos háttértudást jelentenek az adott szakterületen.

A Higher National Diploma Programme-ok - Emelt Szintủ Nemzeti Diploma Programok - Felsőfokú szakképzések hazai rendszeréhez hasonlítanak legjobban. Ezek az erősen szakmai alapú kurzusok lépcsőzetesebb haladást nyújtanak a felsőoktatásba. A sikeres diákok ezen a szinten nyerhetnek felvételt vagy egyfajta garantált bejutást az egyetemre.

A legnépszerübb szakmai programok a következő vizsgákat tartalmazzák, ami azt jelenti, hogy ezek nem képzési, hanem képesítési rendszerek (vizsgaközpontok):

- $\quad$ BTEC Award (Business And Technology Education Council)

- NVQ

- City and Giuld Qualification

- Apprenticeship Programme - Gyakornoki program

Angliában 4 vizsgáztató szervezet ad ki A level minősítéseket:

(1) $\mathrm{AQA}^{25}$ - Assessment and Qualifications Alliance, kormánytól független, különböző tárgyakból tartanak vizsgákat, és adnak ki különböző szintủ tanúsítványokat GCSE, AS, A level és szakképesítéseket.

(2) $\mathrm{OCR}^{26}$ - az Egyesült Királyság másik vezető vizsgaközpontja, ugyanakkor képzéseket is nyújtanak különböző életkorú személyeknek, iskolarendszerü, részidős, munka melletti tanfolyamokkal egyetemben.

\footnotetext{
${ }^{23}$ Apprenticeships, Skills, Children and Learning Act 2009

http://www.legislation.gov.uk/ukpga/2009/22/contents

${ }^{24}$ Education Act (2011). http://www.legislation.gov.uk/ukpga/2011/21/contents

${ }^{25} \mathrm{http}: / /$ www.aqa.org.uk/

${ }^{26} \mathrm{http}$ ://www.ocr.org.uk
} 
(3) Pearson ${ }^{27}$ Edexcel, a Pearson a világ vezető oktatási cége, melynek vizsgáztatással foglalkozó része az Edexcel ${ }^{28}$. Minden szinten nyújt képzéseket és vizsgalehetőséget UK-on belül és kívül egyaránt. Specialitása az általa alapított BETEC (Business and Technology Education Council) vizsgarendszere, melyet 2009/10 akadémiai évben 80 országban 1,1 millió tanulót regisztrált.

(4) Végül, de nem utolsósorban a WJEC - Welsh Joint Education Committee, ami az Egyesült Királyság egész területén nyújt vizsgákat, végez oktatáskutatás és fejlesztést, támogatja a felnőttek tanulását, és specialitása a fiatalok müvészeti tevékenységének támogatása.

Az említett 4 szolgáltató tehát nem csak a minősítések, vizsgák területén nyújt szolgáltatásokat, de kiterjedt képzési szolgáltató is, iskolarendszerü és iskolán kívüli képzésekben 19 év alattiak és felnőttek számára egyaránt, de a szakmai továbbképzésekben is szerepet vállalnak. Müködésüket vizsgálva elmondhatjuk, hogy a továbbképzések és szakképzés különböző szegmensei a szolgáltatók szintjén nem különülnek el, legföljebb szektoriális hangsúly eltolódások vannak. A minősítési rendszer ugyan nem egységes, de nem a célcsoportok mentén tagolódik, hanem különböző kategóriák, kritériumok alapján a jelölt alkalmasságát, hozzáértését minősíti a nagyon pontosan definiált Minősítési Keretrendszer mentén. A szegmenseket a finanszírozás, és az életkori csoportok összefüggésében kezelik külön.

\section{Academic Qualifications}

A legtöbb angol iskola un. „6th Form” azután következik, hogy megszerezték a (General Certificate of Secondary Education) GCSE's vizsgát, ami egyfajta alapvizsga. Akik nem teszik le ezt a vizsgát, „6th For Colleges”-ben, lehetőséget kapnak ezt később pótolni. Ezekben általában A szinten folyik a képzés, a felsőoktatásba való bejutáshoz ez kevés, további akadémiai (elméleti) minősítést kell szerezniük. Az A-szinthez két év alatt jutnak el, amikor a GCSE's vizsga teljes 6 modulból álló A minősítés és egy 3 modulos fél AS szint. A diákok általában 2-3 A-szintet tesznek le, de az akadémiai képességeiktől és motivációiktól függően teljesíthetnek többet is. Egy független (magán) iskolában a diákok akár 5 Aszintet is teljesíthetnek, míg másol kettő is nehezen sikerül.

Az A-szint alternatívájaként számos angol középiskola Nemzetközi Érettségi Vizsgát (International Baccalaureate) is kínál, ezek száma azonban még nagyon alacsony. Az iskolarendszerrel kapcsolatos kritikák során kitérünk a vizsgarendszer szigorításával kapcsolatos szakmai véleményekre.

\footnotetext{
${ }^{27} \mathrm{http}: / / \mathrm{www} \cdot$ pearson.com/

${ }^{28} \mathrm{http}: / /$ www.edexcel.com
} 


\section{A szakképzés problémái a 2000-es évek elején}

\section{A kompetencia alapú megközelités ellentmondásai}

Az angol szakképzési rendszer problémáinak gyökerére jól rámutat Brockmann és munkatársainak tanulmánya (2008), amely a szakmai képzés angliai gyakornoki rendszerét (Apprenticeship) a céhes hagyományokra vezeti vissza, amelyben a mester a munkavégzés során vezeti be a tanoncot a szakma ismeretébe, gyakorlatába és a munkavilágába. A legalacsonyabb végzettség nem jogosít fel önálló munkavégzésre, csak irányítás mellett (NVQ1). A szakmai önállóság lépésről lépésre nő az egyes szinteken, a középfokú képzésekben zömében 1-es vagy 2-es NVQ-ra felkészítő kurzusokat kínálnak. A legújabb UTC-ékben már 2-es 3-as szakmai szintü képesítéseket találunk, melyek felkészítenek az egyetemi felvételi vizsgára, valamint az alapvizsgára, ha eddig valaki még nem szerezte meg, mivel 11 évesen jelentkezett a 6th Form képzési formára. Számuk azonban még mindig elenyésző.

A bírálók szerint ez az alacsony kimeneti szintü képzési rendszer sem innovatív tudást nem tartalmaz, hiszen csak az alapmüveletek ismétléséig jut el a tanuló, sem élethosszig tartó karriert nem tud biztosítani, továbbá a szociális és foglalkoztatási mobilitáshoz sem tud hozzájárulni. Az angol kompetencia modellt $\mathrm{M}$. Brockmann et al. (2004: 527) ,rigid, visszafelé térképező módszerként jellemzik, amelyben a szakma alapja a mühelyben van, ami érinthetetlen kiindulópontja a kompetenciák meghatározásának, megszokott munkaköri leírások vezérlik, amiből a proaktív és reflektív dolgozót kihagyják.” (id: Brockmann, 2008)

Az NVQ rendszerrel összekapcsolt szakmaiság úgy tünik azokban a gazdasági szektorokban eredményes, melyek erősen tagolt munkamegosztáson alapulnak. A munkavállalók rutin feladatokat végeznek újra meg újra, egyre ügyesebben.

Összhangban az akadémiai és a szakképzés angliai kettősségével a reformokat megelőzően a VET rendszere csak az általános képzés legalacsonyabb szintü fogalmait tartalmazta, leginkább az általános foglalkoztathatóság megteremtése volt a célja. Az úgy nevezett általános készségek oktatását - mint írás-olvasás, számolás, informatika - csak az iskola elhagyók / pályakezdők szegényes funkcionális képességeire való válaszként vezették be.

A szakképzési rendszer a munkáltató által vezérelt, minimális alapkészségeket biztosította csak olyan mértékben, amennyi a feladat elvégzéséhez éppen szükséges volt. (Jessup, 1992 id: Brockmann, 2008). Ezt a formát eredetileg azzal a céllal vezették be a 70-es években, hogy csökkentsék a magas fiatalkori munkanélküliséget. A képzési rendszer kettősségét sok kritika éri, különösen, amióta a megújuló felsőfokú szakképzések rendszerét (UTC) az egyetemekhez kapcsolták. 


\section{A Nuffield Jelentés 2008- „Gyakornoki rendszer (Apprenticeship), növekedési} kilátások. ",29

Az angol oktatáspolitikában számos felmérés, összefoglaló jelentés született az oktatás helyzetének elemzéséhez. Ez a jelentés több éves információ gyüjtés után arra keresi a választ, a 16 éves kort betöltöttek körében milyen mértékben járul hozzá a képzésben való részvétel növeléséhez a gyakornoki rendszer Angliában. Mennyiségi szempontból vizsgálja a gyakornoki rendszer alakulását. A második kérdés, a gyakornoki rendszer minőségével foglalkozik. Elismeri a jelentős javulást a szakmai végzettségek megszerzésében, de azt is vizsgálja, hogyan lehet a jövőben javítani a 14-19 évesek oktatási és képzési rendszerének általános teljesítményét.

A 16 évet betöltöttek képzésének egyik célja, hogy 2015-re a 17 évesek részvételi aránya a képzésben 90\%-ra növekedjen. A másik szándék, hogy 2013-ra a 19 évesek 85\% érje el a 2. képzettségi szintet (az egyes szint felügyelet alatt végzett segédmunkaként értelmezhető, a második szint, már betanított munka, azaz meghatározott részfeladat önálló végzésére jogosít). Ehhez járult hozzá az a jogszabály módosítás, ami a tankötelezettséget 18 éves korra emelte. Így az első elvárás feltétele könnyen megvalósul, hiszen a tanulók közel 100 százaléka 17 éves kora után is a képzésben marad. A rendszer, ami a megnövekedett hallgatói létszámot befogadja, több különböző mértékben elkülönült pályát kínál. Egyrészt a GCSE - GCE A szintjének tanulási útvonalát, melyek főként a felsőoktatásba vezetnek. Ezek a vizsgák alkalmazott, általános szakmai utak, ahol az új diplomák versenyeznek számos vizsga központ által kínált végzettséggel. A szakmunkás út, vagyis a gyakornoki rendszer 16-19 évesek és idősebbek számára áll rendelkezésre.

Az aktuális kormány (2007 - Prime Minister Gordon Brown) nagy várakozással tekintett a Gyakornoki rendszerre. Azt remélte, hogy kulcsfontosságú szerepet játszhat a kormányzat kitüzött céljainak elérésében a részvétel és a teljesítmény növelésében az oktatás területén. A jelentések azonban nem ezt igazolták (Leitch Review of Skills 2006). Brown miniszter 2007-ben a Greenwich Egyetemen tartott beszédében hangsúlyozta, hogy a gyakornoki rendszert teljes egészében át kell alakítani, a finanszírozását az egyetemekhez hasonló módon egy ellenőrző szervnek kell gyakorolni (lásd UCAS), és a finanszírozásban a magánszektornak és üzleti szférának is nagyobb szerepet szánnak.

David Lammy, a Gyakornoki rendszerért felelős miniszter szintén a munkáltatókkal való együttmüködésben látta a 2020-ra kitüzött célok megvalósításának

\footnotetext{
${ }^{29} \mathrm{http}$ ///www.nuffieldfoundation.org/sites/default/files/files/3\%20Apprenticeship $\% 20 \mathrm{I} \%$ 20Prospects\%20for\%20growth.pdf Apprenticeship I Prospets for growth 2008 Nuffield Foundation.
} 
esélyét, ami négyszázezer gyakornoki helyet jelent. A munkáltatók, a tanulók, és képzést nyújtók együttmüködése szerinte oda fog vezetni, hogy 2013-ra elegendő számú és minőségü munkavállaló lesz a fiatalok körében. Az idő úgy tünik ismét nem őt igazolta, a szakemberek és az újabb jelentések legalábbis a korábbihoz hasonló aggodalmakról számolnak be az eltelt 5-6 év után is.

A Lordok Házának Gazdasági Ügyekért Felelős Bizottsága (House of Lords Select Committee for Education) vitatja, hogy a gyakornoki rendszer lenne a legmegfelelőbb megoldás, a diploma alatti szinten. A kormányzati nyilatkozatok mind a kereslet és a kínálat között kialakult egyensúly hiányára utalnak. A keresleti oldalon több jól képzett szakmunkásra van szükség, miközben a kínálati oldalon folyamatos problémákkal találkozunk.

Más ágazatokban, melyekben nagy hagyománya van a minősítéseknek, mint például a mérnöki és építőipari szektorban, ráhangolódtak a korábbi nagy múltú képzési programokra, számos munkáltató kezdeményezi, hogy a dolgozói szerezzék meg a szükséges NVQ képesítéseket. Ezzel szemben a nemzetközi tendenciákat is az jellemzi, hogy a munkaadók visszavonulnak a képzéssel kapcsolatos kötelezettségvállalásból. Hiányában a kormányzati kezdeményezések (Train to Gain) során ösztönzőket dolgoznak ki, hogy vegyenek részt a képzésekben, támogassák a dolgozók képességeinek korszerüsítését. A munkáltatók csak az NVQ 2-3 szintjének megszerzésére motiváltak, így ezek száma nő meg erőteljesen, ami az alacsony végzettségü munkavállalók foglalkoztatási csapdáját eredményezik.

Az országos képzési jegyzék integrálja ugyan a szakmai és akadémiai képesítéseket, de ezek egyenértéküsége megkérdőjelezhető, az említett elméleti alapok hiánya miatt, föként az alacsonyabb szinteken. Grugulis (2004) beszámol a szakmai polarizációról és az alacsony képzettséget igénylő szakmák nagy arányáról az UK-ban (27\% 2001-ben), ami együtt jár az autonómia és a döntési jogkör csökkenésével. Ebben a vonatkozásban úgy tünik, a szakképzés jól tükrözi az angol munkaerőpiac struktúráját.

Egyes szakmákban nyilvánvalóan magasabb elméleti tudás szükséges a szakmai kompetenciához, ami megköveteli a felsőfokú végzettséget, ilyen például a szoftverfejlesztés és az ápolói szakma is. Ezeket a foglalkozásokat az NVQ rendszer is máshogy kezeli. A minősítési rendszer legfőbb kritikája, hogy a gyakornoki rendszer inkább a munkáltató rövid távú érdekeit szolgálja ki, és nem ad a munkavállaló kezébe széleskörü és átfogó lehetőséget. 


\section{A Wolf Jelentés ${ }^{30}$}

2010-ben a kormányváltás után prof. A. Wolf M. Gove oktatási államtitkár felkérésére jelentést készített a szakképzési kurzusokról azzal a céllal, hogy hogyan lehetne javítani a gyakorlati oktatást. Wolf elemzésében és ajánlásaiban kiemeli, hogy számos, tizenévesek számára tömegesen oktatott kurzusnak semmilyen haszna nincs a munkavállalás szempontjából. Példaként hoz egy képesítést a személyes hatékonyság növelése területén, melyben azt tanították a tizenéveseknek, hogyan igényeljék a munkanélküli juttatásokat és használják a telefont. Ezt kínálta az ASDAN jótékonysági szervezet csaknem 11000 embernek a múlt évben, ami egy GCSE minősítést ért ${ }^{31}$.

Wolf másik példájában arra utal, hogy néhány szakmunkás képzés nagyon jó az építöipar és a kézmüipar területén, a fodrász tanfolyamnak is nagyon jó a standardja, de a legtöbb kurzus semmire nem használható. Számos esetben már a tanfolyamok minősítésének elfogadását is hibásnak tartja. A finanszírozásnak a diákokat kellene követni, ahelyett, hogy az intézményeknek adják a képzésre. „Olyan rendszerünk van, amiben a szakképző intézményeket a kiadott minősítések után fizetik."- állapítja meg a szerző. Wolf javasolja, hogy vezessék be a szakmai képzésekbe az elméleti tárgyak oktatását, mint például a matematikát és angolt, ahogy Németországban teszik

Mindez egybecseng számos korábbi tanulmánnyal, melyben az angol szakmai képzések tartalmi kérdéseit feszegetik. Brockmann és munkatársai egy 2008-as tanulmányukban az angol és a francia szakképzési rendszer programjait elemzik, és rámutatnak a szakképzés angol típusának koncepcionális problémáira. Az angol rendszer a munkahelyen megszerezhető képességekre épít, kevéssé veszi tekintetbe a formális tanulási formát, célja a minősítéshez való hozzáférés kiszélesítése. A kompetencia meghatározása a minősítési rendszerben (NVQs) nem a szakképzési programhoz kötődik, hanem valójában a teljesítményértékeléséhez. Ez a megközelítés alapvetően eltér a legtöbb holisztikus modelltől, ahol a vizsga és a képzés kapcsolatban marad a tananyaggal. Ez a „tanfolyam” orientált rendszer olyan szakmai ismereteket eredményez, aminek kevéssé vagy egyáltalán nem meghatározott az elméleti tudás háttere. Az NVQs munkaalapú képzései mellett léteznek strukturált szakképzési progra-

\footnotetext{
${ }^{30}$ Review of Vocational Education - The Wolf Report 2011.

https://www.education.gov.uk/publications/standard/publicationDetail/Page1/DFE00031-2011

${ }^{31}$ Hasonló jelenségek hazánkban is megfigyelhetőek az alacsonyan kvalifikált munkaerő képzése során.

Vocational education not good enough, says Wolf report. By Angela Harrison. http://www.bbc.co.uk/news/education-12622061
} 
mok is, mint például a BTEC National Diplomas, melyekben nagyobb hangsúlyt kapnak a tudásalapú elemek.

Az utóbbi 10 évben (2011 a jelentés éve) a szakképzési minősítések száma robbanásszerüen megnőtt, többen aggódnak hogy ezek nem megfelelő minőségüek. Az egyik vezető vizsgabizottság, az Edexcel jelentése szerint a szakképzésben minősítést szerzett tanulók száma a 2003-as 66000-röl több mint 700000re emelkedett. Wolf, aki a képzés és a munkaerő piac közötti viszony szakértője, nem helyesli a gyakorlati minősítések növekedését. Arra figyelmeztet, hogy 16 és 19 évesek több mint negyedét, csaknem egyharmadát ez a képzés nem juttatja álláshoz, vagy további képzési programokhoz.

Prof. Lora Undin a Londoni Egyetem szakképzésének szóvivője abban egyet ért Wolffal, hogy túl sok fiatalember van olyan képzésekben, melyek nem elég jók (nem jók semmire?). Unwin kiemeli az 1-es és 2-ees NVQ szintet, melyek egyenértékủek a GCSEs-vel. „Túl sok ember van alacsony képzettségi szinten. Ezek a kurzusok nem elég fejlesztőek, mert a minősítések egyszerüen nem elég jók" mondta. Unwin ugyanakkor azonban óva inti a kormányt, hogy az egész minősítési rendszert összezúzza és az alapokról építse fel. A szakképzési rendszer - szerinte - az utóbbi 40 évben a politikusok játszótere volt, megszámlálhatatlan kísérlet történt megalapozott nemzeti jövőkép és egyetértés (consensus) nélkül. „Bármi legyen is a Wolf vizsgálat ajánlása, szükségünk van a nyilvános viták időszakára, mielőtt bármilyen változtatást végrehajtanánk. Ellenkező esetben megismételjük a múlt hibáit." - nyilatkozza a BBC-nek.

A Wolf vizsgálat az UTC müszaki iskolákat ösztönzi, melyek magas szintü müszaki ismereteket tanítanak a 14-19 éveszeknek. A tanfolyamokat a munkáltatókkal és az egyetemekkel dolgozzák ki és együtt müködtetik a képzéseket. Mégis a tanárok szakszervezetei aggódnak, hogy így elkülöníthetik azokat a tanulókat, akik az elméletben (academical subjects) és akik a gyakorlatban tehetségesek. Az is probléma lehet, hogy ezek az iskolák elvonják a forrásokat a már létező főiskoláktól. Szakértők szerint a Wolf jelentés fö üzenete, hogy meg kell állítani Angliában a vízvezeték szerelők és kőmüvesek szakmájának leértékelödését. A Németországihoz hasonlóan olyan szakmai kultúrát kell teremteni, amelyben megbecsülik a szakmákhoz szükséges képességeket és komoly tudást.

\section{Az angol szakképzés jelenleg zajló reformfolya- mata}

A jelenlegi konzervatív kormány Oktatási Államtitkára, Michael Gove kezdeményezésére a középiskolai érettségi rendszer átfogó reformját indította el (General 
Certificate of Secondary Education - GCSE ). Az első új rendszerü érettségik 2015-ben lesznek. Ezzel egy időben nyilvánosságra hozták a „,a Középiskolai Angol, Matematia és Természettudomány Nemzeti Kerettantervét" (National Curriculum Programmes of Study for KS4 English, Maths and Science), megváltozik a vizsgáztatás helye (minden külső vizsgáztatókhoz kerül) és az ellenőrzések módja is. A vizsgáztatás struktúráját az Ofqual szervezi, míg a tartalmi követelményeket angol, matematika, természettudományok történelem és földrajz területén a DfE (Department for Education, Oktatási Minisztérium) egyezteti. A tartalmi kérdések mellett számos szervezeti változás is történt a rendszerben.

A reform törvényi hátterét Angliában a 2009-es Oktatási Törvény (Apprenticeships, Skills, Children and Learning Act ${ }^{32}$ ), valamint a 2011-es Oktatási Törvény (Education Act $2011^{33}$ ) jelenti. A törvények szabályozzák az iskolakötelezettséget, és az iskolarendszerü képzéseket 19 éves kor alatt, valamint a továbbképzési rendszert és a felnőttképzést. A törvény alapján kinevezték a Szakképzési Alap vezérigazgatóját, megalapították a Képzési Ügynökséget „The Young People's Learning Agency" elnevezéssel, ami a 19 éves kor alatti iskolaköteles tanulók számára nyújt oktatást és képzést, valamint a tanulási nehézségekkel küzdő 19 és 25 év közöttiek diákoknak. Ezen kívül személyes szolgáltatásokat biztosítanak az oktatás területén gyermekkortól fiatalkorig. Feladata még, hogy tájékoztatást adjanak a Helyi Oktatási Hatóságok (LEAs - Local education authority) szerepéröl az oktatás képzés területén a törvényi elöírások szerint.

A reform részeként a kormány számos új hivatalt és funkciót vezetett be a szakképzés minőségfejlesztése és ellenőrzése érdekében. Ezekkel igyekeznek a forrásokat és a célokat összehangolni, a rendszert átláthatóbbá tenni. Külön hivatalt hoztak létre a képzési és intézményi akkreditációk és a vizsgáztatás koordinációjára (Office of Qualifications and Examinations Regilations - OQER / Képesítési és Vizsgaszabályozási Hivatal). A képzések és tananyagok fejlesztését a Képesítési és Tantervfejlesztési Ügynökség (The Qualifications and Curriculum Development Agency QCDA) koordinálja. A hivatali ügyintézés lebonyolítása mellett a program kiterjed a végrehajtás szintjére is, hiszen a képzésekben résztvevők számára is biztosít szolgáltatásokat, például a már említett NAS (National Apprenticeship Service) ${ }^{34}$, programjai, valamint a National Carrers Service ${ }^{35}$ hálózata, ami az egyéni képzési utak megtervezésében nyújt információs és tanácsadó szolgáltatásokat.

A reform szorosan kapcsolódik az Egyesült Királyság négy országára kiterjedő Ágazati Minősítési Reformhoz (Sector Qualification Reform), melynek kereté-

\footnotetext{
${ }^{32}$ http://www.legislation.gov.uk/ukpga/2009/22/contents/enacted

${ }^{33} \mathrm{http}: / /$ www.legislation.gov.uk/ukpga/2011/21/contents

${ }^{34} \mathrm{https}: / / \mathrm{www}$.youtube.com/user/ApprenticeshipsNAS

${ }^{35} \mathrm{https}: / / \mathrm{www}$.youtube.com/user/RightDirectionForYou
} 
ben egy cselekvési tervet dolgoztak ki az Egyesült Királyság Commission for Employment \& Skills (UKCES), a Sector Skill Councils (Ágazati Szakképzettségi Tanács) és a Standard Setting Bodies (Szabványügyi Testületek) bevonásával. Kidolgozták a Qualifications and Credit Framework (QCF) Képesítési Keretrendszert, az Ofqual a nemzetek szakképzésért felelős szervezetével (LSC, DCELLS, CCEA) biztosítja a változásokhoz szükséges infrastruktúrát ${ }^{36}$. Érezhetően támaszkodtak a piaci szereplökre a tervezés során, akik a finanszírozásban már kevésbé vállalnak felelősséget.

A képesítési keretrendszer - QCF - tartalmazza a képzések fejlesztésével és megvalósításával kapcsolatos információkat, sarokpontokat a kormány, a képző intézmények, szolgáltatók széles tábora számára (tanácsadók, tutorok is). A Skill Founding Agency (hasonlóan az egyetemek finanszírozásához) szintén a QCFen keresztül finanszírozza a 19 éves kor utáni továbbképzési és szakképzési rendszert. Tanácsokkal és javaslatokkal segíti a tanulókat az eredményesség érdekében, amit egy nyilvántartási rendszerben (Personal Learning Record Service $^{37}$ ) lehet nyomon követni, a tanulók egyedi tanulói számot (Unique Learner Numbers ${ }^{38}$ ) kapnak, így a végzettségeket személyhez kötötten tartják nyilván. Ez annál inkább fontos, hiszen a költségeket 19-25 éves kor között fele fele arányban viseli a kormány és az egyén.

A Skills Founding Agency dönti el, mit finanszíroznak a 19 év felettiek képzésében, amit a SQS cselekvési tervet kidolgozó Sector Skills Councils ajánlásai alapján választanak ki, szemben a korábbi kontroll nélkül burjánzó, sokat bírált tréningekkel. Minden SFA által indított programot (Adult Responsiveness, Train to Gain; Programmes for the Unemployed, Offender Learning and skills Service, and Apprenticeships) értékel a QCF, amihez viszonyítva eldöntik a finanszírozást, ha a program céljai megfelelőek. A képzések tartalmának támogatni kell a foglalkoztathatóság növekedését, a munkavállalók szükségleteit, valamint a munkaerőpiac hatékonyságát. 2010-ben adták ki az online listát a finanszírozás minősítési feltételiröl.

A SFA további programjai.

- $\quad$ Adult Learner Responsiveness (Felnőtt Tanulási Fogékonyság)

- $\quad$ Train to Gain (Tanulj, hogy nyerj)

- $\quad$ Programmes for the Unemployed (Programok munkanélkülieknek)

- Offender Learning and Skill Service (OLASS)

\footnotetext{
${ }^{36} \mathrm{https}$ //www.gov.uk/government/policies/improving-the-quality-of-further-educationand-skills-training

${ }^{37} \mathrm{http}: / /$ www.learningrecordsservice.org.uk/

${ }^{38} \mathrm{http}: / / \mathrm{www}$. learningrecordsservice.org.uk/products/uln/
} 
Az átmeneti időszakában biztosítja a finanszírozást a korábban indult képzések befejezéséhez.

- $\quad$ Apprenticeships (Gyakornoki Rendszer)

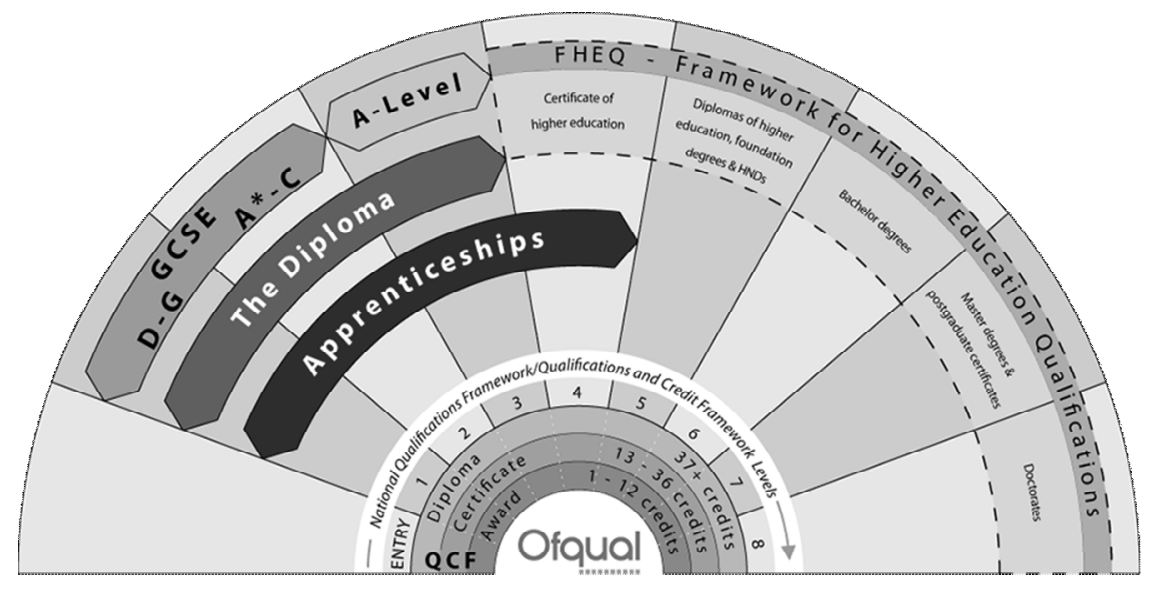

3. ábra. A képesítési rendszer egyenértéküsége Angliában.

Forrás: Ofqual (Office of Qualifications and Examinations Regulation) http://ofqual.gov.uk/help-and-advice/comparing-qualifications/

2009-ben nyilvánosságra hozták a Gyakornoki rendszer új leírását, a Specification of Apprenticeship Standard for England (SASE), amit össze kellett fésülni a minösítési rendszerrel is (QCF, NQF). Az új rendszer a különböző vizsgarendszerek minősítéseit összehangolja és átjárhatóvá teszi azt a kredit átszámítás szabályozásával, elismeri a megszerzett krediteket, ezzel különböző tanulási útvonalakat ajánl a tanulóknak. Ehhez jól használható adatbázisokra van szükség, hiszen a képző intézmények és a képzési szolgáltatók száma nagyon nagy, az általuk nyújtott tanfolyamok és képzések igen szerteágazóak. Az Oktatási Minisztérium által fenntartott állami oktatási intézményeket tartalmazza az EduBase ${ }^{39}$.

Az oktatási reformok, azon belül is a szakképzés átalakítását célzó változások ismertetéséből kitünik, mennyire átfogó strukturális változásokról van szó. A keretek, szabályozók, intézmények és müködésmódok alapvető megváltoztatása a meglévő oktatási intézmények és vizsgáztatók megőrzése mellett történikKísérletet tesznek a rendszer és a források összehangolására az Egyesült Királyság országai között és nemzeti szinten egyaránt, hogy a követelmények és az

\footnotetext{
${ }^{39} \mathrm{http}: / / w w w . e d u c a t i o n . g o v . u k /$ edubase/home.xhtml
} 
ellenőrzés szigorításával jobb minőségủ szakképzés valósuljon meg. A szabályozás és ellenőrzés növelésével az egyéni igényekhez és a változásokhoz való alkalmazkodás képessége csökken, a helyi oktatási nevelési problémákra csak lokális szinten tudnak megoldásokat találni. Kérdés, hogy a rendszer mennyi rugalmasságot enged meg.

A szabályozásban megjelenik a gazdasági szereplők bevonása, de a finanszírozásban még mindig az államé a vezető szerep. A szükségletek felmérése és a képzések fejlesztése, valamint a gyakorlati képzésben a helyi igényekre építenek, és gazdasági szereplőket is igyekeznek aktivizálni, de az oktatási rendszer szabályozásának ezt a szakaszát inkább a szakértők szük csoportjának a bevonásával történő irányítás jellemzi. Az oktatási szereplők a reformok eredményességének megítélésben megoszlanak, széles rétegük szkeptikus, az önállóságukat vesztett jól képzett tanárok kiábrándultan hagyják el a pályát.

A független külső minősítő rendszer megkívánja a képzés tartalmának, tananyagoknak a pontosabb elöírását, kidolgozását, hogy a vizsgakövetelmények egyértelmüek legyenek. Ennek érdekében mindegyik vizsgaközpont részletes tananyagot mellékel minden általa minősített képzéshez, a kapcsolódó módszertani, és tartalmi segédeszközökkel együtt. Erre szükség is van, hiszen a belső vizsgáztatás csak az angol, a nyelvtan és történelem területén maradt meg. A tananyagok online bárki számára hozzáférhetőek az ismertetett központok honlapján. Ezenkívül létezik egy központi ellenörzött tudásbázis, amit a felhasználók folyamatosan fejlesztenek.

A korábbi keretrendszert a felhasználói oldal irányította. A kompetenciák meghatározása a munkaköri feladatok elemzésén alapult, amit a teljes foglalkozási területen feltérképeztek. Az egyes funkciókat kombinálták a kompetencia elemekkel (társított teljesítmény kritériumokkal), melyeket szükségesnek ítélnek az egyes munkakörök ellátása során. Ezeket rendezték csoportokba, amit az egyes szakma NVQ-ja tartalmaz. Ugyanakkor az egyes képesítések (NVQ) kompetenciái nem kapcsolódnak tanagyagokhoz és elméleti szakmai ismeretekhez (szakismeret, anyagismeret), maga a minősítés a tanulók gyakorlati teljesítményének értékelési rendszere, amit az elöírt és elvégzett feladatokon keresztül mérnek. Így ahelyett, hogy a minősítést követően az akkreditált szakképzési programot reprezentálná, olyan kompetenciák elismerése, melyeket leginkább munkatapasztalat során szereznek, mintsem szakképzési kurzusokon. Jellemzö, hogy az elméleti tudást nem értékelik külön, bár fontosnak tartják, úgy vélik tükröződnie kell e feladat teljesítésében. A kompetenciák értékelése függ a munkahelyi teljesítménytől, így közvetve a munkáltatótól, akivel szerződéses kapcsolatban van.

Az új rendszer a fenti a gondolkodásmódot igyekszik alapvetően megváltoztatni. Elöször is minden szinten kötelezővé teszi az angol nyelv, és matematika oktatását, hangsúlyozza az idegen nyelv és a természettudományok oktatását is, 
valamint az IT és a tanulási készségek, mindennapi képességek fejlesztését, különösen a szerényebb képességü tanulók esetében. A modulokból egyéni tanulási útvonalakat választhat ki a tanuló, melyekben a tankötelezettség és a továbbtanulás szorosan összefügg.

Fontos cél, a szakképzettség növelése a Level 2 szintről (részfeladatokat önállóan elvégezni képes betanított munkás, akinek a feladata jól körülhatárolt) a Level 3-ra (önállóan dolgozó felelős szakmunkás, aki átlátja a gyártási folyamatok, az eszközök és a rendszer müködését). Fontosnak tartják az alaptanulási készségek fejlesztését és megtartását a felnőttképzés segítségével, azaz az olvasási, számolási készségek erősítését. A felnőttek vizsgálata (International Assessment of Adult Competencies - PIAAC) és a PISA felmérések azt mutatták, hogy az oktatási költségekhez és a többi tagállam (UK) eredményéhez viszonyítva Anglia gyengébben szerepelt. Sok a tanulók által félbe hagyott képzés, ami szintén pazarlás. Az akadémiai vizsgarendszer (GCSE A level) szigorításával, mintha igyekeznének az egyetemi tudományos képzések felől a szakképzésbe irányítani a fiatalokat. Az egyetemi, felsőoktatáshoz való belépéshez szükséges végzettség elérésére csak a különösen felkészült jó képességü tanulók számára válik hozzáférhetővé, még a jó és átlagos képességüeket a szakmai képesítések megszerzésére buzdítják. Hasonlóan hazánkhoz, a szakképzés hagyományos rendszere kiürült, motiválatlan, szerény képességü, hátrányos helyzetü fiatalok maradtak többségükben a rendszerben, újra teremelve az alacsony képzettséggel járó elhelyezkedési problémákat és a munkáltatók elégedetlenségét az alacsony képességü munkavállalókkal. Jellemző azonban, hogy a mégoly konzervatív oktatási államtitkár is támogatta a tankötelezettség felemelését, ugyanakkor a19 éves kor feletti szakképzés esetében is fizetni kell a tandíj 50\%-át.

\section{A továbbképzés és a szakképzés minőségének fejlesztése}

A közelmúltban a kormány megrendelésére készült, egy független szakértői jelentés „Richard felülvizsgálat $2012^{40}$, néven, amely áttekinti a Gyakornoki rendszer aktuális helyzetét és problémáit és javaslatokat fogalmaz meg a beavatkozások irányaira. Fontosnak tartja újra definiálni a szakmunkásképzéshez kapcsolódó fogalmakat, melyek negatív minősítéseket kaptak a közvéleményben. Ehhez a kutatók véleménye szerint a szakmákat, a képesítéseket is újra kell fogalmazni. A munkáltatói igények érvényesülésének is nagyobb teret kell adni. Fontos kérdésnek tartja a tanulmány, hogy hogyan lehet közelíteni a munkavállalók és a munkáltatók igényeit, és összeegyeztetni az egyéni és a szélesebb gazdasági szempontokat. Javaslata szerint meg kell vizsgálni, hogy mely elemeket kell egyszerüsíteni vagy eltávolítani a rendszerből. El kell dönteni, kinek is szól

\footnotetext{
${ }^{40}$ https://www.gov.uk/government/uploads/system/uploads/attachment_data/file/34708/ri chard-review-full.pdf
} 
a szakképzés, kinek származik a legtöbb haszna belőle (tanulók és munkáltatók egyaránt). Olyan minősítési rendszer szükségességét fogalmazza meg, amit elfogadnak és értékelnek a munkáltatók. Központi problémának tartja, hogy hogyan lehet azt megvalósítani, hogy a gyakornoki rendszer inkább új ismereteket és készségeket adjon, és ne a már meglévőket erősítse meg. Végül, de nem utolsósorban a szakképzésbe való befektetések ár-érték arányának javítását veti fel.

A beruházások és reformok ellenére az iskolaköteles korúak körében a a gyakornoki rendszer népszerüsége csökkent, a kezdeti sikerek után a program megtorpanni látszik ${ }^{41}$.

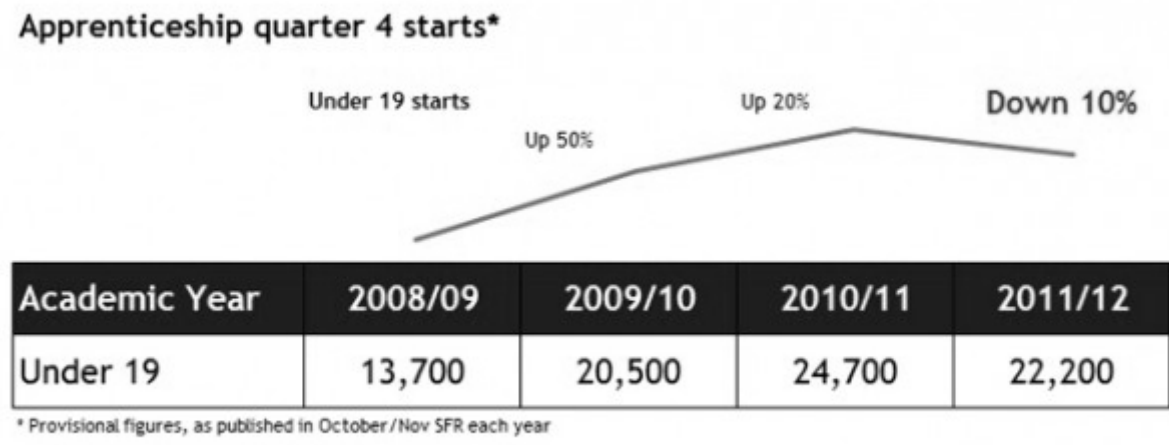

4. Táblázat. A gyakornoki rendszer.

Forrás: http://feweek.co.uk/2012/10/11/government-figures-reveal-a-ten-per-cent-fall-in16-18-apprenticeships/

A Gyakornoki rendszer (Apprenticeship) fejlesztése továbbra is prioritást élvez a kormány részéről, annak ellenére, hogy 2010 és 2011 között 10\%-kal csökkent a 16-18 évesek részvétele a rendszerben (bár a 25 feletti korosztályban nőtt). A kormányzat az oktatás fejlesztése terén töretlenül tevékenykedik, a szakértői jelentések mellett a tárgyi feltételek fejlesztésére 2013/14 és 2014/15 között 550 millió GBP tőkebefektetést fordítanak a továbbképzési intézetek felújítására (FE College $)^{42}$.

\footnotetext{
${ }^{41} \mathrm{http}: / / w w w . t e l e g r a p h . c o . u k /$ finance/jobs/9470715/British-apprenticeship-figuressuggest-drive-has-stalled.html

${ }^{42}$ FE College Capital Investment Strategy.

https://www.gov.uk/government/uploads/system/uploads/attachment_data/file/69800/121340-further-education-college-capital-investment-strategy-plan.pdf
} 


\section{Összegzés}

Az angol oktatási és szakképzési rendszer tanulmányozása során egy meglehetösen nagy múltú, nagy tekintélyü rendszerrel ismerkedhetünk meg. Hatalmas intézményrendszer, apparátus, és szakmai tapasztalat áll mögötte és a lassan 50 évre visszatekintő adósságok és a folyamatos változtatási kísérletek ellenére úgy tünik, erősen őrzi a hagyományokat, gyakran akár a modern kori kihívások ellenkező igényei ellenére is. Nem könnyü egy minősítés központú rendszert, a maga kiterjedt vizsgahálózatával és annak finanszírozási struktúrájával áthangolni, és az elmélyültebb szakmai ismeretekre épülő, az elméleti tudást és a gyakorlati készségeket ötvöző szakképzési filozófia irányába elmozdítani.

A fiatalok egy része az egyetemi diplomák irányába mozdult el - Magyarországhoz hasonlóan - ,jelentősen meg is nőtt a diplomások száma, ugyanakkor a leszakadt, az oktatási rendszerből rendkívül alacsony végzettséggel kikerülők tömegeivel is számolni kell. A munkavégzés tartalma, minősége sok ágazatban erőteljesen változik, a tudás értéke, pénzben kifejezhető differenciáló szerepe éppen ezért megerősödik. Nehéz megtalálni az egyensúlyt a túlképzés és az alul-képzés között. A társadalmi jellegü problémákra az oktatás képtelen válaszokat adni, de a helyzetet a nem megfelelő beavatkozásokkal bizony jelentősen ronthatja. Gondolunk itt a társadalmi különbségeket fokozó szelekciós mechanizmusokra, miközben az elosztás problémái már nem csak a javakhoz való hozzáférésben, hanem a munkához és a tanuláshoz, tudáshoz való hozzáférésben is megjelennek.

Önmagában ezeket a mély társadalmi problémákat egyetlen oktatási rendszer sem képes megoldani, hiába tesz akár erőn felül is erőfeszítéséket, ahogy az angol oktatási rendszer példája is mutatja. Ahogyan az oktatás nem képes önmagában kezelni a társadalmi problémákat, az oktatás politika sem tudja a rendszert csupán a szabályozók változtatásával átalakítani. Az értékek, szemléletmód, változása lassú folyamat, a szereplők aktív bevonása nélkül szinte esélytelen a kívánt eredmények elérése. Az új társadalmi és gazdasági kihívásokhoz új, talán szokatlan megoldások, ötletek megszületése szükséges, melynek kereteit a széles társadalmi vita, a konszenzus kialakítása teremti meg. A vita talán lassítja a reformfolyamatokat, valódi változások azonban csak a rendszer tagjainak belátásán, együttmüködésén és elköteleződésén alapulhatnak. Nincs az a szigorú kontroll és ellenőrzés, ami kiküszöböli a végrehajtás szintjén müködő emberek döntési szabadságát, érzelmi, akarati ellenállását, vagy éppen tehetetlenségét. Elöfordul tehát, hogy a kevesebb változás a több, és a lassabb a gyorsabb, de legalábbis hatékonyabb a szó minőségi értelmében. 


\section{Felhasznált irodalom}

1. Alexander, Robin (2012) Moral Panic, Miracle Cures and Educational Policy: what can we really learn from international comparison?, Scottish

Educational Review 44 (1), 4-21.

http://www.scotedreview.org.uk/pdf/335.pdf

2. Alexander RJ (2010) 'Post-election priorities from the Cambridge review'

The Guardian 27 April.

http://www.guardian.co.uk/education/2010/apr/27/primary-education-

cambridge-review-election

3. Alexander RJ (2009a) 'What is the primary curriculum for?' The Guardian 7 April.

http://www.guardian.co.uk/education/2009/apr/07/crib-sheet-april

4. Alexander RJ (2009b) Children, their World, their Education Final Report and Recommendations of the Cambridge Primary Review London:

Routledge.

5. Alexander RJ and Flutter J (2009a) Towards a New Primary Curriculum: a report from the Cambridge Primary Review. Part 1: Past and Present Cambridge: University of Cambridge Faculty of Education.

http://www.primaryreview.org.uk/Downloads/Curriculum_report/CPR_Cur ric_rep_Pt1_Past_Present.pdf

6. Alexander RJ and Flutter J (2009b) Towards a New Primary Curriculum: a report from the Cambridge Primary Review. Part 2: The Future Cambridge: University of Cambridge Faculty of Education.

http://www.primaryreview.org.uk/Downloads/Curriculum_report/CPR_Cur ric_rep_Pt2_Future.pdf

7. Atkins, Flint, Oldfield: Practical matters: what young people think about, vocational education in England City \& Guilds Centre for Skills Development June 2011.

http://www.skillsdevelopment.org/pdf/Practical\%20matters\%20$\% 20$ England $\% 20$ report.pdf

8. Brockmann M. Clarke L.MéhautF.Winch C. (2008) Competence-Based Vocational Education and Training(VET): the Cases of England and France in a European PerspectiveVocations and Learning (2008) 1:227-244. http://link.springer.com/article/10.1007\%2Fs 12186-008-9013-2?LI=true

9. Coffey, M. - Rhodes, C. (2002): Structure and funding of vocational education and training in the United Kingdom, Ireland, France and Germany, UTS Research Centre for Vocational Education and Training, Sydney http://www.voced.edu.au/content/ngv36114

10. Halász G (2010): Coping with complexity and instability in the VET system of the United Kingdom. http://halaszg.ofi.hu/download/UK-VET.htm 
11. Hansen K. and Vignoles A (2002) The United Kingdom Education System in Comparative Context.

http://www.cls.ioe.ac.uk/library-

media $\% 5$ Cdocuments $\% 5$ CThe $\% 20$ UK $\% 20$ Education $\% 20$ System $\% 20 \mathrm{An} \%$

20International\%20Perspective.pdf

12. Hoeckel K., Cully K., Field S., Halász G. and Kis V. (2009) OECD

Reviews of Vocational Education and Training: A Learning for Jobs

Review of England and Wales.

http://www.oecd-ilibrary.org/education/oecd-reviews-of-vocational-

education-and-training-a-learning-for-jobs-review-of-england-and-wales-

2009_9789264113763-en;jsessionid=8qgdc1q4gf4u.x-oecd-live-01

13. Lauterbach, U. and Sellin, B. (2000): Comparative Vocational Education

and Training Research in Europe: Balance and Perspectives; Cedefop/DIPF

Conference.

http://www.cedefop.europa.eu/EN/Files/BonnReaderEN.pdf

14. West J. - Steedman H.(2003) Finding Our Way: Vocational Education in England.

http://eprints.lse.ac.uk/13485/1/OP018.pdf

15. Structures of education, vocational training and adult education systems in Europe 2003.

http://eacea.ec.europa.eu/education/eurydice/documents/eurybase/structures /041_UN_EN.pdf

16. White, A. (2010) Turning the clock back to subject slavery. http://www.tes.co.uk/article.aspx?storycode $=6035006$

17. White, A. (2011) 'A properly rounded academic education'. http://www.philosophy-of-education.org/uploads/papers2011/WhiteJ.pdf

18. White, A. (2011) Gove's on the Bac foot with a white paper stuck in 1868. http://www.tes.co.uk/article.aspx?storycode $=6068033$

19. Wolf, A. (2011) Review of Vocational Education - The Wolf Report. https://www.education.gov.uk/publications/standard/publicationDetail/Page 1/DFE-00031-2011

20. Vocational education and training at higher qualification levels (2011). http://www.cedefop.europa.eu/EN/Files/5515_en.pdf

21. Vivian, D. ; Winterbotham, M. ; Shury, J. ; Davies, B. (2011): Employer Skills Survey 2011 First Findings UK Commission for Employment and Skills.

http://www.ukces.org.uk/assets/ukces/docs/publications/uk-ess-firstfindings-2011-amended-22-dec.pdf 
Internetes hivatkozások:

1. Business Plan 2012-13 of National Apprenticeship Service http://www.apprenticeships.org.uk/AboutUs/ /media/Documents/NAS2012 13BusinessPlanforstakeholders-July2012.

2. Department for Education. https://www.education.gov.uk/

3. Education in England. http://www.educationengland.org.uk

4. European Credit System for Vocational Education and Training (ECVET) for England. http://www.ecctis.co.uk/ecvet/default.aspx

5. European Centre of Develop of Vocational Training CEDEFOP. http://www.cedefop.europa.eu

6. The Education, Audiovisual and Culture Executive Agency (EACEA) Eurydice. http://eacea.ec.europa.eu/education/eurydice/

7. National Board of Education. http://www.oph.fi/english/education/vocational_upper_secondary_educatio $\mathrm{n}$ and training Finish

8. Tehnical and Vocational Training United Kingdom TVT UK. http://www.tvetuk.org/en/home

9. University Technical Colleges. http://www.utcolleges.org/

10. BBC Education and Family. http://www.bbc.co.uk/news/education

11. Ofqual a Szakképzés, a képesítések, vizsgák és értékelések szabályozója Angliában és Észak-Írországban. http://www.ofqual.gov.uk/about-us/

12. List of Additional Regulatory Documents Regulatory documents still in force from the 18th July 2011 onwards - a vizsgák kritériumokat szabályozó dokumentumok összesítése.

http://www2.ofqual.gov.uk/downloads/category/109-regulatory-documents

Zolnai Erika: pszichológus, főiskolai adjunktus

Debreceni Egyetem Egészségügyi Kar, 4400 Nyíregyháza, Sóstói u. 2-4. 


\section{Mellékletek}

1. számú Melléklet.

Az oktatási szakaszok, életkor; iskola év, Isced; KS és a különbözően tagozódó iskolatípusok összegző táblázata

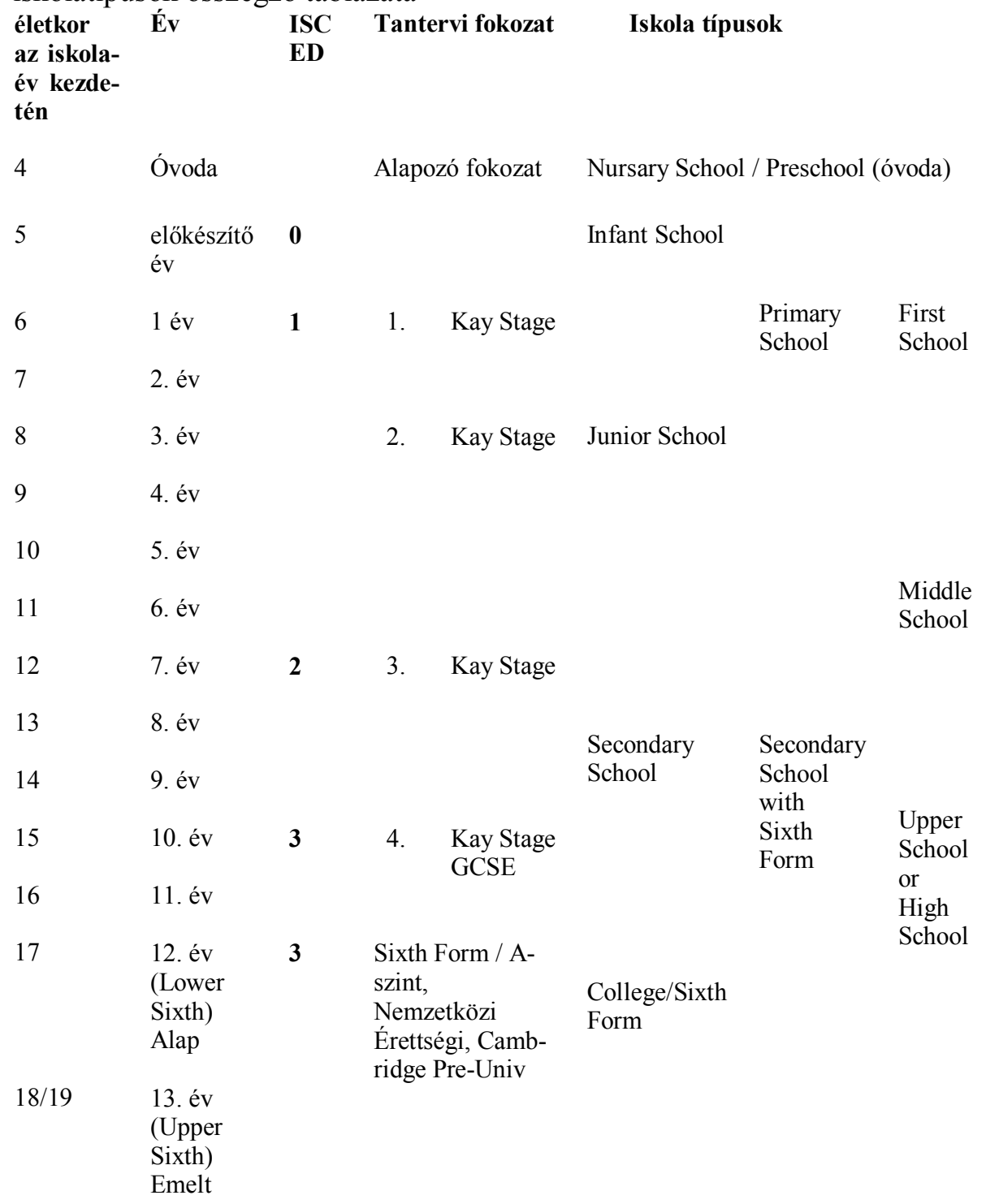

Forrás: saját szerkesztés, Eurydike és egyéb oldalak alapján 
2-es számú melléklet.

Az angol oktatás struktúrája szintek, iskolatípusok iskolaév és életkorok mentén.

\begin{tabular}{|c|c|c|c|c|c|c|}
\hline \multirow[b]{2}{*}{$\begin{array}{l}\begin{array}{l}\text { Phase of } \\
\text { education }\end{array} \\
\text { Higher } \\
\text { and fur- } \\
\text { ther edu- } \\
\text { cation }\end{array}$} & \multicolumn{2}{|l|}{$\begin{array}{l}\text { Type of institution } \\
\text { Intézmény típus }\end{array}$} & & \multicolumn{2}{|c|}{$\begin{array}{c}\text { Year/grade } \\
\text { key }\end{array}$} & \multirow{2}{*}{\begin{tabular}{|c}
$\begin{array}{c}\text { Typical } \\
\text { age }\end{array}$ \\
$18+$
\end{tabular}} \\
\hline & $\begin{array}{l}\text { Further education } \\
\text { inst.Szakképzö Föisko- } \\
\text { lák, ,,Harmadik Föisk., } \\
\text { Specializált Föisk., } \\
\text { Felnöttképzési közpon- } \\
\text { tok" } \\
\text { (such as further educa- } \\
\text { tion colleges, tertiary } \\
\text { col., specialist col., and } \\
\text { adult education centres) }\end{array}$ & $\begin{array}{l}\text { Higher education } \\
\text { institutions } \\
\text { (egyetemek és egyéb } \\
\text { felsőoktatási intézmé- } \\
\text { nyek) } \\
\text { universities and other } \\
\text { higher education insti- } \\
\text { tutions) }\end{array}$ & & 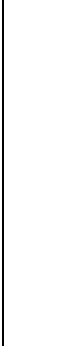 & & \\
\hline \multirow[t]{4}{*}{$\begin{array}{l}\text { Upper } \\
\text { secondary } \\
\text { education }\end{array}$} & \multicolumn{6}{|c|}{$\begin{array}{l}\text { GCE "A' Levels, GCE "AS" Level examinations and Advanced Vocational Certificates of } \\
\text { Education (AVCEs) (taken at age 17/18) provide access to further and higher education } \\
\text { and the world of work } \\
\text { GCE „,A", GCE „AS” és AVCEs vizsgák, melyek hozzáférhetövé teszik a szakképzést és } \\
\text { felsöoktatást és a munka világát. }\end{array}$} \\
\hline & $\begin{array}{l}\text { Further education } \\
\text { institutions / szak- } \\
\text { képző int. }\end{array}$ & $\begin{array}{l}\text { School sixth forms } \\
\text { or sixth form col- } \\
\text { leges /hat oszt. Form. }\end{array}$ & & & & $17-18$ \\
\hline & & & & & & $16-17$ \\
\hline & \multicolumn{6}{|c|}{$\begin{array}{l}\text { General Certificates of Secondary Education (GCSEs), General National Vocational Quali- } \\
\text { fications (GNVQs) and GCSEs in vocational subjects (Vocational GCSEs) (usually taken at } \\
\text { age 16) provide access to post-compulsory general/academic and vocational studies and } \\
\text { the world of work } \\
\text { GCSEs és GNVQs és Szakmai GCSEs záró, vagy képesitö vizsgák ált. } 16 \text { évesen teszik le, } \\
\text { átvezet a kötelezó képzés utáni általános, akadémiai és szakképzésbe, vagy a munka világá- } \\
\text { ba } 2012 \text {-töl } 18+\text { éves korig tart a tankötelezettség }\end{array}$} \\
\hline \multirow[t]{5}{*}{\begin{tabular}{|l|} 
Lower \\
secondary \\
education
\end{tabular}} & \multicolumn{2}{|c|}{$\begin{array}{c}\text { Secondary schools / középiskolák több } \\
\text { típusa }\end{array}$} & Key stage 4 & Y11 & \multicolumn{2}{|c|}{$\begin{array}{l}15- \\
16 * * * * *\end{array}$} \\
\hline & & & & Y10 & & -15 \\
\hline & & & & Y9 & & -14 \\
\hline & & & $\begin{array}{c}\text { Key } \\
\text { stage3**** }\end{array}$ & Y8 & & $-13 * *$ \\
\hline & & & & Y7 & & $-12 * *$ \\
\hline
\end{tabular}




\begin{tabular}{|c|c|c|c|c|}
\hline \multirow[t]{6}{*}{$\begin{array}{l}\text { Primary } \\
\text { education }\end{array}$} & $\begin{array}{c}\text { Primary schools* / általános iskolák } \\
\text { több típusa }\end{array}$ & \multirow[t]{2}{*}{$\begin{array}{l}\text { Key stage } \\
2 * * * *\end{array}$} & Y6 & $10-11 * *$ \\
\hline & & & Y5 & $9-10 * *$ \\
\hline & & & Y4 & $8-9 * *$ \\
\hline & & & Y3 & $7-8$ \\
\hline & & \multirow{2}{*}{ Key stage 1} & Y2 & $6-7$ \\
\hline & & & Y1 & $5-6$ \\
\hline & $\begin{array}{l}\text { Reception classes }(R) \text { in } \\
\text { primary sch. }\end{array}$ & $\begin{array}{l}\text { Early Years } \\
\text { Foundation } \\
\text { stage } * * *\end{array}$ & $\mathrm{R}$ & $4-5$ \\
\hline \multirow{2}{*}{$\begin{array}{l}\text { Pre-school } \\
\text { and nursery } \\
\text { education }\end{array}$} & \multirow{2}{*}{$\begin{array}{l}\text { Pre-school settings which include pre- } \\
\text { school groups, playgroups, day nurseries, } \\
\text { nursery centres and nursery schools }\end{array}$} & & & $0-5$ \\
\hline & & & & \\
\hline
\end{tabular}


3-as számú melléklet.

A VET rendszerében résztvevő iskolatípusok és formák.

Primary Education

Secondary Education

Upper Secondary \& Postcompulsory

Higher Education
Primary Schools

Secondary Schools2

1. Community Schools

2. Foundation Schools

3. Voluntary Schools

4. Academies

5. Studio Schools

6. University Technical Colleges (jelenleg müködik:6, folyamatban:4)

Secondary Schools - Sixth Forms

1. Sixth Form College

2. Further Education College

3. Specialist College

4. Tertiary College

Higher Education Institutions

1. Further Education College

2. University

3. University College
Age 4 to 11

Age 11 to 16

Age 16 to

$18+$

Age $18+$

forrás: http://www.7eu-vet.org/uploadi/editor/1326448027England OverviewofVETSystem.pdf 
4-es számú melléklet.

A gyakornoki rendszerben tanulók számának és összetételének változásai.

Forrás: http://www.significancemagazine.org/details/webexclusive/2085083/YoureHired-Apprenticeships-since-the-1950s.html

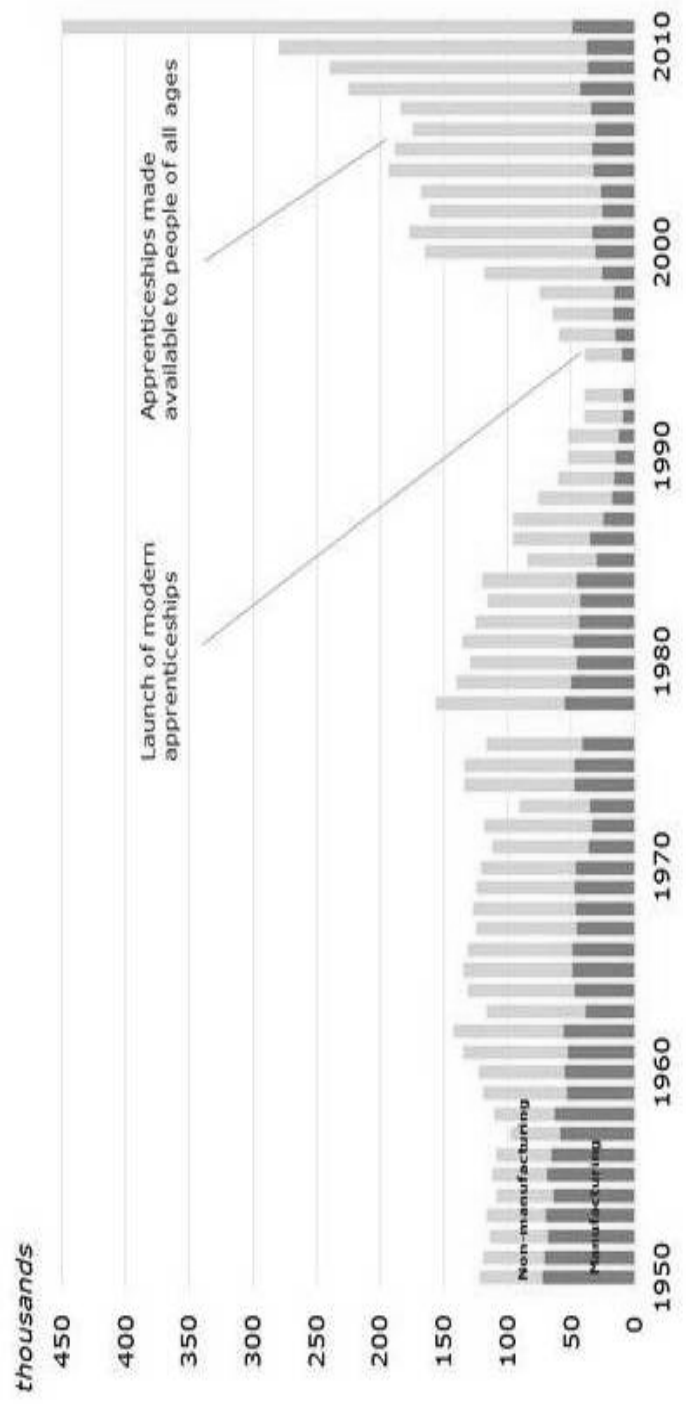


5-ös számú melléklet.

A minősítések egyenértéküsége.

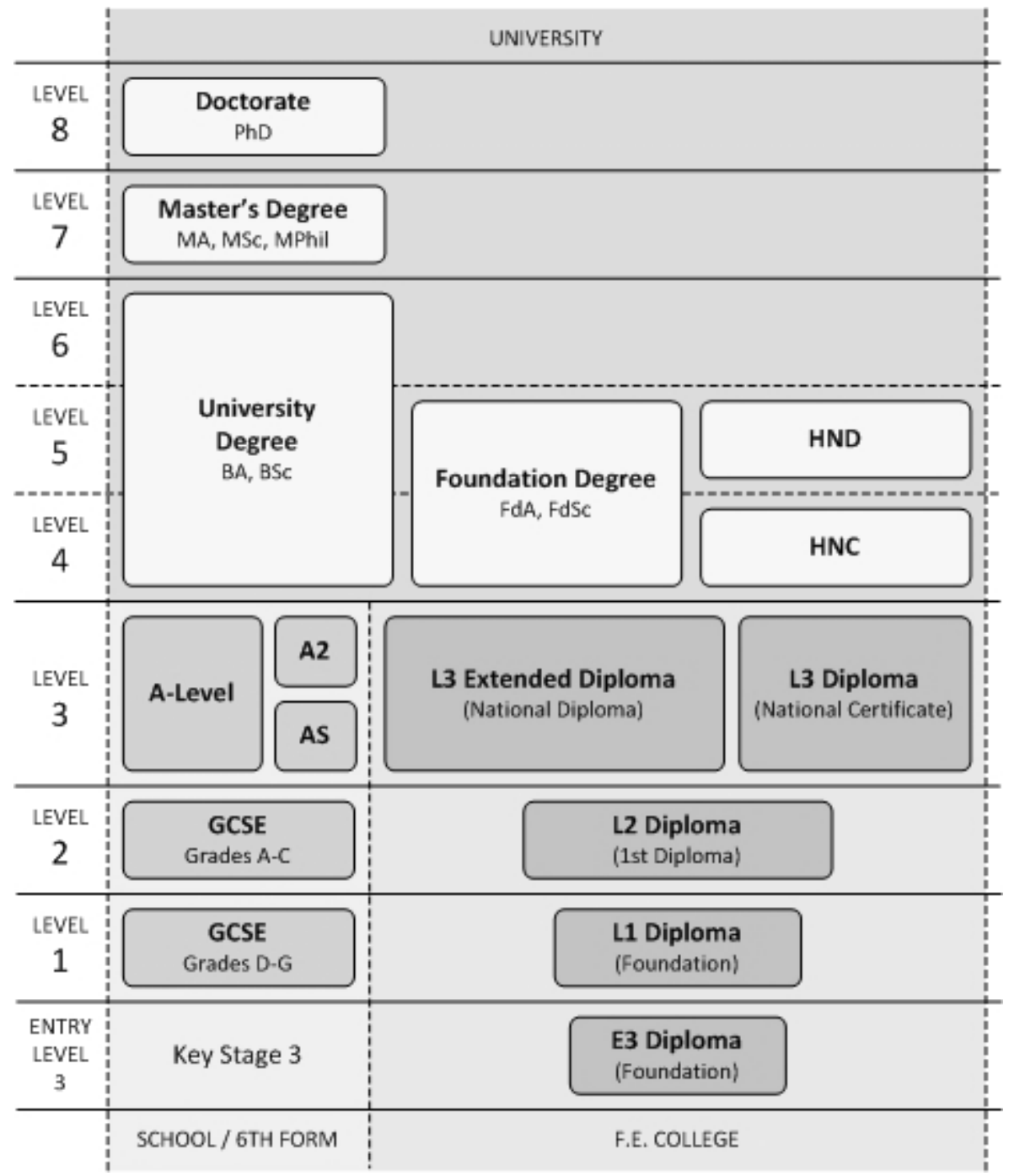

Forrás: http://www.caduk.co.uk/aboutus.html 


\section{UNIVERSITY}

OF DEBRECEN

FACULTY OF

HEALTH

NYíREGYHÁZA

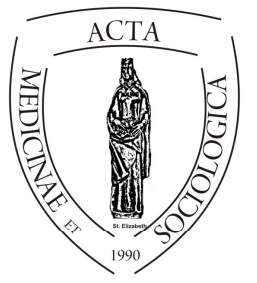

ACTA

MedSoc

VOLUME 5.

2014

\title{
Gondolatok és reflexiók a „Helyi szociális ellátórendszer Magyarországon" címü kötetről
}

\author{
Szatlóczkyné Gajdóczki Zsuzsanna \\ Apor Vilmos Katolikus Főiskola
}

A kötet a ,jóléti állam” specifikumát meghatározni kívánó tudományos kísérlet sikeres alkotása. Nem csupán a gazdasági és politikai megközelítést állítja a középpontba, hanem a társadalmi, kulturális aspektusokat. Itt az ideje, hogy a kultúrára fókuszáljunk.

Jean Monnet, Európa egyik atyjának utolsó szavai az alábbiak: „Ha újrakezdhetném, a kultúrával kezdeném.” Mondja ezt egy latin kultúrkörhöz tartozó, a civilizációtörténetet ismerö francia (Russel 1996: 20)

De mi is a kultúra? Létezik jó néhányszáz definíciója, de amit ma a globalizáció világában is alkalmazhatunk, ami nem jó, vagy rossz, hanem egy végbemenő folyamat, realitás, azt Kornis Gyula írta meg, „Tudomány és társadalom A tudomány szociológiája" címen, melyet a Franklin Társulat 1944-ben adott ki Budapesten. Kornis a társadalmat alkotó embert egyben és egészben láttatja, a kultúrát az alábbiakban határozta meg közel 600 oldalas művében:

A kultúra területei: a tudomány, a művészet, a vallás, az erkölcs, a jog, a gazdaság, és a politika, így együttesen!

Ez az a szellemi tudományos alkotás, amelyet az Európai Unió, avagy az Euroatlanti Szövetség humánerőforrás stratégiájának kellene alkalmaznia, hogy 
ne csak gazdasági-és védelmi-stratégiája legyen, hanem humánerőforrás stratégiája is. Véleményem szerint a világválság fö oka ennek hiányából fakad.

Azért tartom nagyszerűnek a helyi szociális ellátórendszereket vizsgáló könyvet, mert szinte egyedülállóan fogta meg a ,jóléti állam”fogalmát, és támasztja alá alapos szociológiai felmérésekkel Kornis igazát. Hiánypótló munka! Szinte az egyetlen, amihez a szakdolgozó főiskolások, egyetemisták bátran nyúlhatnak a felmérés adatait illetően, saját vizsgálataik folytatásához. Ahhoz hasonlóan, ahogy Kornis Gyula könyve is korát jó pár évtizeddel megelőzte, az évezredek óta kipróbált értékeket helyreállítva müvében, a bemutatott kötet szerkesztői és szerzői is, szándékosan vagy sem, figyelemre méltó eredményeket fogalmaznak meg.

A kötetben Thomas R. Lawson és Eric R. Soelter is rámutatnak az Egyesült Államok példáján arra, hogy az 1930-as nagy gazdasági világválság idején a felelösség jelentős része a szövetségi államra tolódott. „A különböző célokat egyenként vizsgálva, elsősorban a szövetségi állam feladata a nemzetbiztonság, a helyi önkormányzatoké az oktatás (felsőoktatás szintjéig) míg a gazdasági, jóléti biztonság már az egyén felelőssége."- írják a fent említett szerzők ${ }^{1}$. Hozzátenném, hogy a nevelés is fontos az oktatás mellett, mert az oktatás csupán eszköz az egész ember formálásának segítésére.

Fontosnak tartom ezt a kötetet, mert, ahogy arra Bódi Ferenc utalt Szabó Zoltán munkáit felidéző munkájában ${ }^{2}$. „A politika művelése népismeret nélkül, társadalomismeret nélkül olyan, mint a vajákos asszony kuruzslása." Könyvükkel, kutatásaikkal azon társadalmi jelenségekre hívják fel a figyelmet, melyek ismerete elkerülhetetlen a döntéshozóknak döntéseikhez, melyek napjaink komplex válságával vannak összefüggésben, hisz nemcsak pénzügyi, politikai, gazdasági, társadalmi válságról beszélhetünk, hanem együtt, az EGÉSZ válságáról. Azaz a kultúra egészével kell foglalkozni, ahogyan Kornis értelmezi azt rendszerelméleti, szociológiai múvében.

Fukuyama már két évtizede felvette a bizalom kérdését - ennek a hiánya is része a komplex-válságnak, $\mathrm{s}$ nem hagyható obligon kívül az emberi élet egyik területe sem. Az erkölcsi válsággal nem számolt egyetlen politikai hatalom sem. Nincs kultúrája sem az érdekérvényesítésnek, sem a piaci versenynek. A humán erőforrás ignorálása nagy hiba, mivel a humán erőforrás, a politikai hatalmak szerint nem termelő szféra. Főbenjáró hiba. Demokrácia deficit van és a demok-

\footnotetext{
${ }^{1}$ Lawson \& Soelter (2012) A social Cultural Model of the Evolution of the Welfare State. In: Bódi, F. \& Fábián, G. \& Lawson, R. T (2012) Local Organization of Social Services in Hungary (Crises - Reactions - Changes) Europäischer Hochschulverlag $\mathrm{GmbH} \&$ Co. KG, Bremen, p. 476

${ }^{2}$ Bódi Ferenc (2008): A tardi helyzettől a Cifranyomorúságig. In: Helyi szociális ellátórendszer (szerk.: Bódi Ferenc) MTA PTI, Budapest. (pp. 357-363)
} 
rácia kultúrája is alacsony. Erre reflektálnak Jean Monnet már hivatkozott sorai a kultúráról: „Ha újrakezdhetném, a kultúrával kezdeném!”

Nem tudnak a kultúrák emberei egymásról eleget, hiányos az általános müveltség, nincs jóindulatú párbeszéd a monologizáló világban. Nincs az adott szónak becsülete. Az egyensúly megtalálása lenne a jó minden szinten, a Kornisféle kultúra felfogás alapján, támaszkodva a szociológusok felméréseire, ahogyan kiindulási alap lehetnének ennek a könyvnek az eredményei is.

„A mennyiség az anyagban van, mérhető. A minőség a szellemben, a lélekben található, mennyiségi módon nem mérhető.”- írja Jáki Szaniszló, Templeton-díjas tudománytörténész (a díj az egyik legjelentősebb tudományos kitüntetés). Erre vigyázni kell a kultúra teljes értékü kutatásánál. Meg kell találni ebben is a harmóniát, a józan mértékletességet. Ebben is konszenzust kell találni.

Jövőképet kell adni az embernek, mert ha az nincs, akkor az értelmetlenség vesz rajta erőt. Mindennek alapja a következő generáció iránti felelősség. Minden kornak megvan a maga vonatkoztatási pontja. A szolidaritás és a szubszidiaritás elvének alkalmazása az egyén, a család, és a társadalom életében elkerülhetetlen, ha nem a háborúkban „fejlődo”” világot akarjuk építeni. Amennyiben megvizsgáljuk, hogy a könyv tanulmányai alapján hol tartunk, akkor hozzájárulhatunk ahhoz, hogy körvonalazzuk a társadalom szociális ellátórendszereinek a további céljait és feladatait hazánkban. Ebből a szempontból fontos mü ez a könyv. Nagy segítséget jelent, hogy megtalálhassuk a hidakat, de ehhez a kutatásokat, a felméréseket a kultúra Kornis-féle értelmében ki kell terjesztenie a tudományos világnak. A tudomány elveszítheti nimbuszát, privilegizált helyét, ha nem változik ebben az értelemben. Természetesen az egyén felelősségén is nagy a hangsúly. Mahatma Gandhi is azt mondta, hogy ha meg akarod változtatni a világot, akkor kezd el saját magadon. Ily módon lehet „modus vivendire” törekedni és „,pacem in terris” céllal müködni.

Lássuk röviden az egyes tanulmányokat! A kötet tanulmányai természetesen nem előzmények nélkül valók, és itt nemcsak azokra a kutatásokra utalok, melyeken az írások alapulnak. A kötet szerkesztői és részben szerzői is egy nemzetközi tudományos és oktatási hálózat, a LOSS hálózat tagjai. A LOSS (Local Organizations of Social Services) a kilencvenes évek elején alakult, német, magyar, finn, angol és olasz, valamint egyesült államokbeli egyetemek, főiskolák együttmúködésén alapult. Az együttmüködés tudományos, kutatási céljai a szociális ellátórendszerek vizsgálatát és összehasonlítását jelentették, az oktatási program is ezeken alapult. Az együttmüködés szabad hálózati tevékenységet jelentett, így az egye szereplők bizonyos területeken szorosabban müködtek együtt, mások pedig alkalmanként kapcsolódtak a hálózat munkájába. Jelen kötetnek is több kutatási előzménye van, melyet legtöbbször Bódi Ferenc és Fábián Gergely szerkesztett kötetekké. A bemutatott kötetben is az egyik főszereplő 
Bódi Ferenc, hisz ő szerepel a legtöbb írással a müben. A 2011-es kötet már részben azokon a kutatásokon alapult, melyet az OTKA is támogatott, így a recenzált kötet is e pályázat keretében jelent meg ${ }^{3}$.

A kötet nyitó tanulmányát a LOSS projekt egyik katalizátor személyisége írta munkatársával. Thomas R. Lawson, a louisville-i Egyetem professzora a LOSS kutatások és együttműködés meghatározó egyik személyisége (szerzőtársa Eric R. Soelter). Tanulmányukban a jóléti állam fejlődésének szociokulturális modelljét elemzik. Nagy hangsúlyt fektetnek a különböző, lehetséges aktorok által a jóléti rendszerre gyakorolt hatás vizsgálatának, és összevetik a liberális, a konzervatív és a szociáldemokrata jóléti rendszerek sajátos vonásait. Tanulmányuk sok szempontból a kötet egyéb írásainak a teoretikus kereteit vázolja fel.

A globális, modellszerü folyamatok felvázolását a magyar szociális ellátórendszer történeti elemzése követi, Bódi Ferenc tollából. A történeti elemzésben az egyes intézmények és ellátások kialakulásának a feltételeire és a változásokra figyel a szerzö ${ }^{4}$. Ezekbe az előfeltételekbe is ágyazza be a rendszerváltást követő folyamatokat, az ellátórendszer változásait, a szegénységet, az iskolázottságot, a társadalmi kapcsolatok alakulását, és az anómiás folyamatokat is.

Sok szempontból erre a tanulmányra épül Bódi Ferenc és Bódi Mátyás tanulmánya a népességfogyásról és az elöregedésröl $1^{5}$. A cím is sokat sejtet, hisz kisiklott fejlődési pályákra utal. A demográfiai folyamatok történeti elemzése mellett, melyek a kisiklottság elemeit hordozzák, kidolgozzák egy lehetséges modell kereteit, egy járható fejlődési pályáét, mely kitörés lehet az „ördögi körből”: ez pedig nem más, mint a helyi szociális ellátórendszer, a helyi gazdaság, a helyi adók és az emberi erőforrás, a helyi tudás egymást erősítő mechanizmusa.

Tematikailag bizonyos mértékig eltér a kötet tanulmányaitól Bódi Ferencnek és Bódi Mátyásnak a választásokat elemző tanulmánya ${ }^{6}$. A tanulmány a ,választási földrajz" eszközeit alkalmazza, izgalmas térségi különbségeket tárnak fel és jelenítenek meg a társadalomföldrajz eszközeivel. A hat választás eredményei-

\footnotetext{
${ }^{3}$ A kötet az OTKA 81667 sz., „Változások - Válságok - Válaszok (Helyi szociális ellátórendszerek alkalmazkodása Európa perem országaiban)" kutatás keretében készült. A tanulmányok egy része az INNOTARS _08_1_2008_0093 sz. kutatás, „A terület és településfejlesztés forrásallokációjának társadalmasítása” pályázat keretében készült.

${ }^{4}$ Bódi Ferenc (2011): A szociális ellátórendszer kifejlődése Magyarországon, történeti háttér, nemzeti sajátosságok. In: Bódi - Fábián (szerk.): Helyi szociális ellátórendszer Magyarországon. Debreceni Egyetem Kiadó, Debrecen. (pp. 19-36).

${ }^{5}$ Bódi Ferenc - Bódi Mátyás (2011): Népességfogyás elöregedés - kisiklott fejlődési pályák. In: Bódi - Fábián (szerk.): Helyi szociális ellátórendszer Magyarországon. Debreceni Egyetem Kiadó, Debrecen. (37-50).

${ }^{6}$ Bódi Ferenc - Bódi Mátyás (2011): Hol vannak a választók? In: Bódi - Fábián (szerk.): Helyi szociális ellátórendszer Magyarországon. Debreceni Egyetem Kiadó, Debrecen. (51-70).
} 
nek összehasonlító vizsgálata alkalmas társadalomtörténeti folyamatok kimutatására is, így a tematika látszólagos „távolsága” ellenére nagyon is alátámasztja az írás a térségi, települési folyamatok hatását, a történeti minták érvényesülését.

Sok szempontból kapcsolódik Bódiék írásához Fónai Mihályé, aki a települési problémáknak és a lakossági szükségleteknek a helyi politikára gyakorolt hatását vizsgálja. A helyi hatalom, helyi társadalom, helyi politika és az önkormányzatiság összefüggései és a helyi hatalom lehetséges típusai mellett a helyi politikára hatást gyakorló aktorok jelentőségét elemzi. A települések problémái, melyek a kötet szemléletéből eredően jelentős mértékben a helyi szociális ellátórendszerek problémái, valóban hatást gyakorolnak a helyi politika témáira és müködésének módjára is.

A migrációs folyamatokat veszi górcső alá Bódi Ferenc és Giczey Péter. E folyamatokat a középkortól napjainkig tekintik át, a demográfiai folyamatok leírása mellett a társadalomtörténeti okokat is bemutatják. A tanulmány írásakor még azt prognosztizálták, hogy a magyar emigráció szerény mértékü lesz más kelet-európai társadalmakhoz képest, a nyelvtudás hiánya, vagy a mobilitási szándék alacsony szintje miatt. Izgalmas a bevándorlókkal kapcsolatos vélemények elemzése, melyben a szerzők a bevándorlókkal, menekültekkel szembeni elutasítást emelik ki.

A történeti, társadalomtörténeti kontextusú írások közé tartozik Bódi Ferencé a komplex válság elemeiről, és azok történelmi hátteréröl. A válságot Bódi az államszocializmusban kialakult, korabeli válságkezelési eljárások hatásaival, a polgárosodás hiátusaival, és a kedvezőtlen társadalmi és demográfiai folyamatokkal magyarázza. A komplex válság eredménye egy ,járadékos ország”, mely morális problémákkal is küszködik .

A kötet egésze jó értelemben vett leíró megközelítéseket alkalmaz, természetesen magyarázó elemzésekkel együtt. Ez a fajta megközelítés az olvasó számára gyakran azzal a képzettel jár, hogy a szerzők „szürkében” látják a valóságot. Tegyük hozzá, lehet, hogy a valóság ilyen, és a szerzők csak érzékeltetni akarják azt - ezt gyakran a tanulmányok címe is mutatja, így Bódi Ferenc és Horváth Zsuzsanna tanulmánya, mely árnyékokról és kísértetekről beszél a vidéki helyi szociális ellátásokban. A szerzők az egészségügyi és a szociális ellátások helyzetét elemzik, hangsúlyozva, hogy a helyi autoritásoknak a segélyek kiosztásán túl nem sok szerepük marad - ez a megállapítás nem a szerzők peszszimizmusából, hanem a vizsgált folyamatok elemzéséből fakad.

Hasonló a tematikája és a megközelítésmódja Obádovics Csilla, Bruder Emese és Kulcsár László írásának is, akik a gazdasági és a szociális helyzet területi egyenlőtlenségeivel foglalkoznak. Vizsgálják a munkanélküliség, a jövedelmi egyenlőtlenségek és a szegénység térbeli megjelenését, a különbségek térbeli eloszlását. Ezt összekapcsolják a „,vidékiség” kérdésével, és megállapítják, hogy 
Magyarországon komoly összefüggés érvényesül a vidékiség és a szegénység között.

Az általános folyamatok helyi, lokális érvényességét vizsgálja Fábián Gergely és Takács Péter. Fábián Gergely a másik szerkesztőhöz hasonlóan a LOSS projekt egyik legaktívabb tagja, az alapítók egyike. Kutatásai a kilencvenes évektől a globális folyamatok lokális megjelenésére koncentrálnak. E tanulmányukban a Nyíregyházán folyó panelvizsgálat eredményeit elemzik, arra kíváncsiak, hogy milyen egyenlőtlenségek jellemzik a város társadalmát, és azok hogyan változtak a válság hatására a foglalkoztatásban, a munkanélküliségben és a jövedelmekben. Ezen túlmenően a helyi segélyezési rendszerről kialakult véleményeket vizsgálják, megállapítva, hogy a segélyezéssel, mint intézménnyel nem, ám a „potyautasokkal” kapcsolatban elutasítóak a város lakói.

A szegénységgel összefüggő jelenséget, a kamatos pénzt vizsgálja Fábián Gergely, Szoboszlai Katalin és Hüse Lajos. A kutatók a Debreceni Egyetem Egészségügyi Karának a munkatársaiként, kutatóként és oktatóként már a kétezres évek elején szembesültek a roma népességen belüli uzsorakamat jelenségével. Kutatásuk döbbenetes képet fest az emberi kiszolgáltatottságról, és a roma közösségek felbomlásáról, a szegények kiszipolyozóiról, a kiszolgáltatottság és a félelem fel nem fogható mértékéröl.

A kötet további tanulmányainak a zöme az iskolarendszer helyzetét elemzi. Bódi Ferenc és Fekete Attila az alapszintü oktatásra ható keresleti és kínálati viszonyokat tárja fel. Keresleti oldalként a demográfiai folyamatokat értik, részletesen kitérnek azok térségi és települések közötti különbségeire is, különös tekintettel a települések méretére, lakónépességére, ami alapvető hatást gyakorol az iskolák megmaradására vagy eltünésére egy-egy településen. A kínálati oldalt az intézményekés a férőhelyek száma és eloszlása, valamint kihasználtsága alakítja. Mivel a magyar társadalomtörténeti hatások miatt az iskola multifunkcionális hatást gyakorolt és gyakorol a települések életére, az iskolák bezárása vagy összevonása a települések további sorsát is alapvetően alakítja.

Ezt a megközelítést és értelmezést érvényesíti Balázsi Ildikó és Bódi Ferenc, az iskolai teljesítmények és átszervezések vizsgálatával. Rámutatnak, hogy a demográfiai folyamatok mellett a finanszírozás átalakítása is komoly hatást gyakorolt az iskolák müködésére, átszervezésére, például a kistérségi együttműködésekre. A bezárt iskolák esetében közrejátszott a szülők döntése is, akik gyerekeiket távolabbi, jobban felszerelt iskolákba járatták - talán nem is volt igény a helyi társadalmakban az iskola megtartására. Fontos az iskolai teljesítmény is, ám a kutatók azt találták, hogy nincs közvetlen összefüggés az iskolák között a családi háttér alapján.

Az iskolák helyzetét elemzi Fekete Attila is, Iskolák a határon címü tanulmányában. A kistérségi társulások, egyáltalán az iskolafenntartó társulások müködésének vizsgálata alapján a szerző úgy látja, az együttmüködés az iskolák 
fenntartásában számos konfliktussal jár együtt, a kölcsönös bizalmatlanság magas szintje mellett. Esettanulmányai alapján a közös iskolafenntartás több típusát is elkülöníti - úgy látja, hogy folyamatos harc folyik a források elosztásáért.

A kötet szerkesztői az iskolai blokkhoz illesztették Laki László és Szabó Andrea tanulmányát, amely az Ifjúság2008 kutatás eredményeit ismerteti. A szerzők a fiatalok anyagi helyzetét és foglalkoztatását vizsgálják, ezeken túlmenően a fiatalok által legégetőbbnek tartott problémákat. Ezek listája is a jövőtlenség, szegénység, munkanélküliség és devianciák köré szerveződik, azaz a fiatalok helyzetértékelése nagyon pesszimista. Az érvényesülés esetében a biztonságot tartják fontosnak, eszközként pedig az összeköttetést, a szerencsét, és a jó családi hátteret emelik ki.

A kötet utolsó két tanulmánya az iskolák kapcsán már érintett elosztási kérdésekkel foglalkozik, általánosabb szinten. Bódi Ferenc, Fekete Attila és Bódi Mátyás a fejlesztési források abszorpcióját vizsgálja. Az abszorpciós képesség alapján a településeket négy csoportba sorolják, majd azt elemzik, hogy az egyes kategóriákba milyen települések milyen módon és eséllyel kerülnek be. A sikerességnek a helyi programok megléte, kiépült intézményhálózat, térségi ellátó szerep és egy „,beágyazott” polgármester volt a feltétele a vizsgált időszakban.

A települések fejlesztéspolitikáját és fejlődését elemzi Bódi Ferenc és Fekete Attila „Magad uram, ha nincs szolgád” találó címü írásukban. A kérdést általánosabb kontextusba helyezve a helyi politikához való viszonyt vizsgálják, összekapcsolva azt a települések sikerességével. A vizsgálathoz klaszterelemzéssel kialakított csoportok jellemző vonásait és választásait vették figyelembe. Eredményeik alapján a politika oldaláról egy zárt világ rajzolódik ki, ami azonban elsősorban a nagypolitikának szól - a település problémái ugyanis érdeklik az ott élőket, igaz, a leghátrányosabb települések lakói nem a helyi politikától sokkal inkább a kormánytól várnak segítséget.

Látható, hogy a kötet írásai viszonylag széles spektrumot fognak át a szociális intézményektöl és kérdésektől az egészségügyön át az iskolarendszerig, azaz átfogják a „LOSS” föbb területeit. Épp emiatt az olvasónak teljes képe lesz a kilencvenes, kétezres évek magyar társadalmáról. A könyvnek nagy érdeme a Mellékletek 80 oldalában közölt diagramok, táblázatok és térképek adatgazdagsága, ami jól támasztja alá és szemléletessé teszi az egész mü tartalmát üzenetét.

Mivel is fejezhetném be könyvismertetőmet? Paul Valéry szavaival, aki szerint „A civilizációk halandók, a kultúra örök!” (Valéry, Paul 1919). Nem elfelejtendő igazság ez sem. Köszönet a könyvért! Alapmunka. Folytassuk ennek alapján tovább, hogy ne válhasson valóra az az anekdota, amit Einsteinnek tulajdonítanak. Állítólag megkérdezték Einsteint valamikor, hogy szerinte milyen fegyverekkel fogják vívni a III. világháborút. Erre (az anekdota szerint) azt válaszolta : „Nem tudom..., de a IV. - et kővel és baltával." 
Remélem, elég ,étvágygerjesztőt” írtam. Ha igen, akkor kérem, olvassák és dolgozzanak belőle, vele az emberi életminőség javítása érdekében.

\section{Források:}

1. Bódi Ferenc (2001): Helyi szociális ellátórendszer vidéken. Budapest: Agroinform Kiadóház.

2. Bódi Ferenc (2008): Helyi szociális ellátórendszer. Budapest: MTA PTI.

3. Bódi Ferenc - Fábián Gergely (2011): Helyi szociális ellátórendszer Magyarországon. Debrecen: Debreceni Egyetem Kiadó Debrecen University Press.

4. Bódi, F. \& Fábián, G. \& Lawson, R. T (2012): Local Organization of Social Services in Hungary (Crises - Reactions - Changes). Bremen: Europäischer Hochschulverlag GmbH \& Co. KG.

5. Fukuyama, Francis (2007): Bizalom. Budapest: Európa Könyvkiadó.

6. Kornis Gyula (1944): Tudomány és társadalom: A tudomány szociológiája I.-II. Budapest: Franklin Társulat.

7. Russel, Eric (1996): Jean Monnet. Paris: Fayard.

8. Jáki Szaniszló (2003): Szellemi önéletrajz hitről és tudományról. Budapest. Kairosz Kiadó.

9. Valéry, Paul (1919): Variations. Paris: Gallimard.

Szatlóczkyné Gajdóczki Zsuzsanna: főiskolai tanár, a GERFEC magyarországi képviselöje Apor Vilmos Katolikus Főiskola, 2600 Vác, Konstantin tér 1-5. 